\title{
Ground-Water Conditions and Studies in Georgia, 2006-2007
}

Scientific Investigations Report 2009-5070
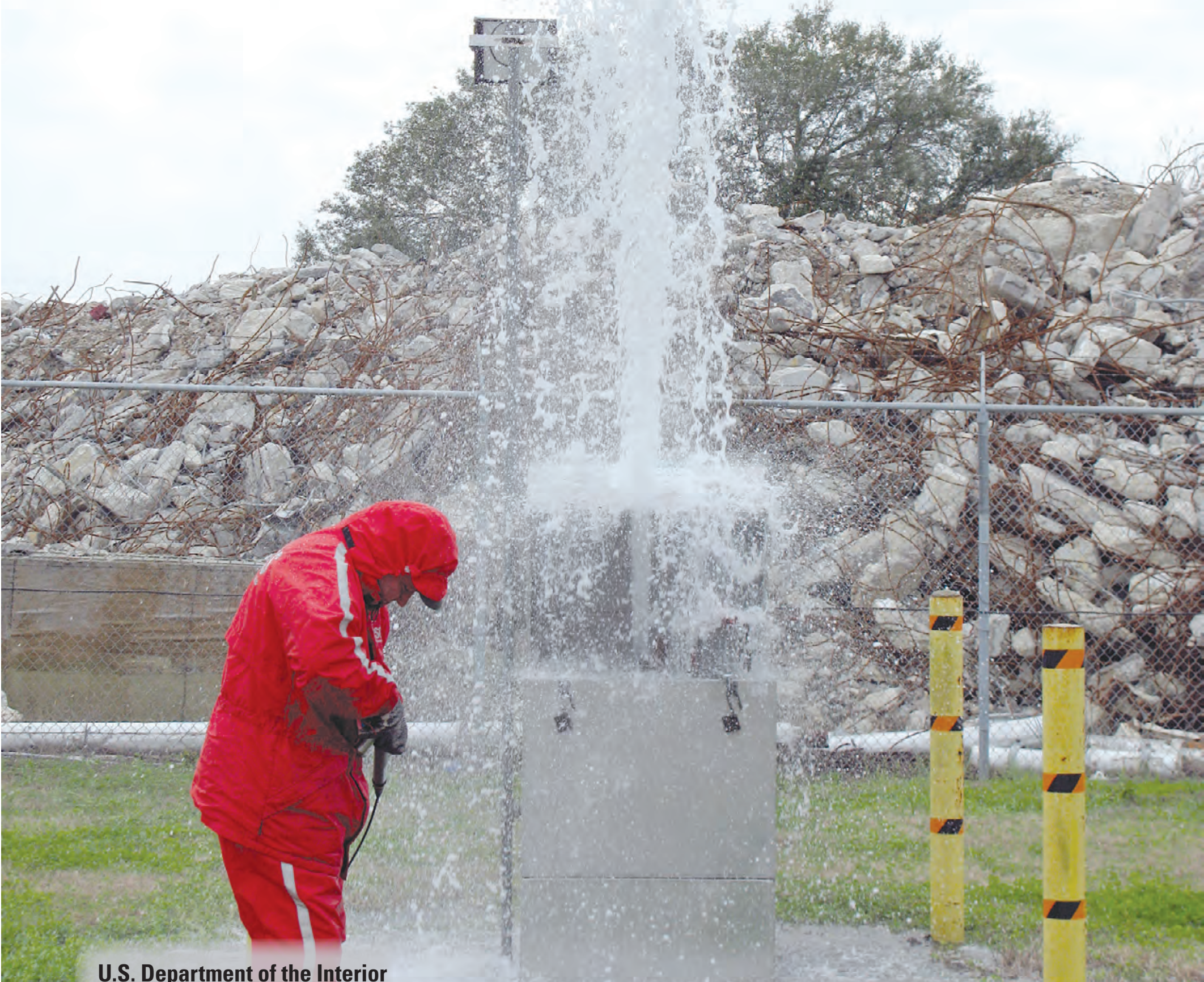

U.S. Department of the Interior

U.S. Geological Survey 


\section{Preface}

This report is published biennially in stop format and presents a summary of ground-water conditions in Georgia, and a description of ongoing ground-water studies. This report is the culmination of a concerted effort by personnel of the U.S. Geological Survey, Georgia Water Science Center who collected, compiled, organized, analyzed, verified the data, and edited and assembled the report. In addition to the authors, who had primary responsibility for ensuring that the information contained herein is accurate and complete, the following individuals contributed substantially to the collection, processing, tabulation, and review of the data:

\author{
Paul D. Ankcorn \\ Gregory S. Cherry \\ John S. Clarke \\ Alan M. Cressler \\ Julia L. Fanning \\ Victor C. Ferreira \\ Debbie Warner Gordon \\ Anthony J. Gotvald \\ Michael D. Hamrick \\ 0 . Gary Holloway
}

\author{
John K. Joiner \\ Stephen J. Lawrence \\ John J. McCranie \\ Jonathan W. Musser \\ Dorothy F. Payne \\ Welby L. Stayton \\ Lynn J. Torak \\ Christopher B. Walls \\ Lester J. Williams
}

Cover. Ground-water monitoring well in Brunswick, Georgia. A hydrologic technician is replacing water-level monitoring equipment. Water level was 10 to 20 feet above land surface, February 2008. Photo by Michael D. Hamrick, U.S. Geological Survey. 


\section{Ground-Water Conditions and Studies in Georgia, 2006-2007}

By Michael F. Peck, Jaime A. Painter, and David C. Leeth

Scientific Investigations Report 2009-5070 


\section{U.S. Department of the Interior \\ KEN SALAZAR, Secretary \\ U.S. Geological Survey \\ Suzette M. Kimball, Acting Director}

U.S. Geological Survey, Reston, Virginia: 2009

For product and ordering information:

World Wide Web: http://www.usgs.gov/pubprod

Telephone: 1-888-ASK-USGS

For more information on the USGS--the Federal source for science about the Earth, its natural and living resources, natural hazards, and the environment:

World Wide Web: http://www.usgs.gov

Telephone: 1-888-ASK-USGS

Any use of trade, product, or firm names in this publication is for descriptive purposes only and does not imply endorsement by the U.S. Government.

Although this report is in the public domain, permission must be secured from the individual copyright owners to reproduce any copyrighted materials contained within this report.

Suggested citation:

Peck, M.F., Painter, J.A.,, and Leeth, D.C., 2009, Ground-water conditions and studies in Georgia, 2006-2007:

U.S. Geological Survey Scientific Investigations Report 2009-5070, 86 p. 


\section{Contents}

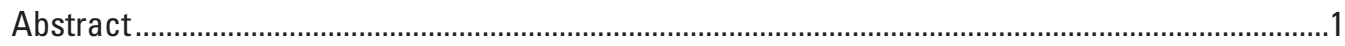

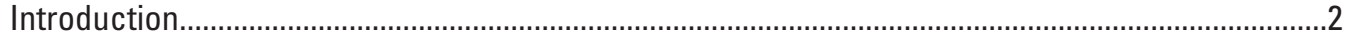

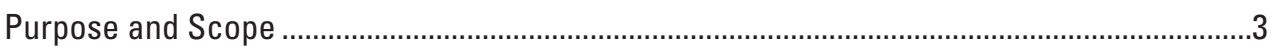

Methods of Analysis, Sources of Data, and Data Accuracy ..................................................

Georgia Well-Naming System .........................................................................................

Cooperating Organizations and Agencies ............................................................................

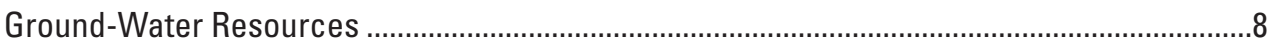

Permitted Water-Use Data for Georgia during 2007 and

Ground-Water-Use Trends for 2003-2007 .................................................................12

Ground-Water Conditions........................................................................................................

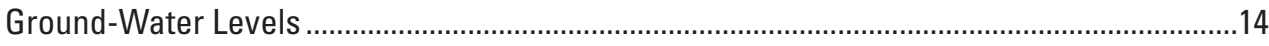

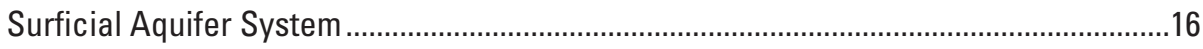

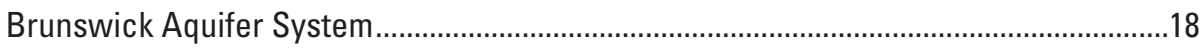

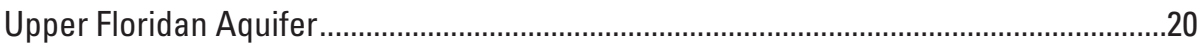

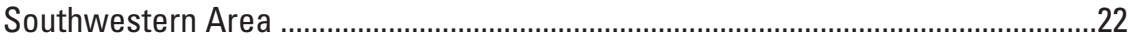

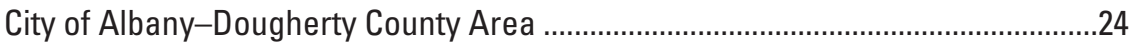

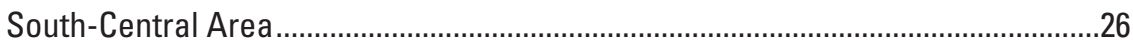

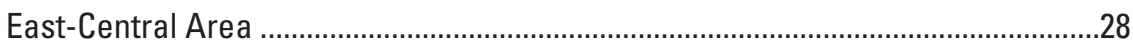

Northern Coastal Area .........................................................................................

Central Coastal Area .................................................................................................

City of Brunswick Area .........................................................................................

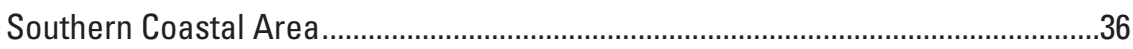

Lower Floridan Aquifer and Underlying Units in Coastal Georgia ...................................38

Claiborne and Gordon Aquifers .....................................................................................

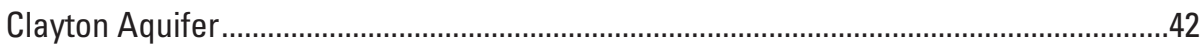

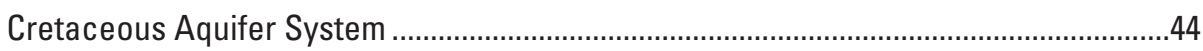

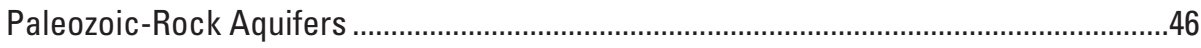

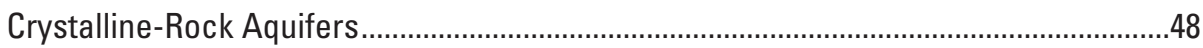

Ground-Water Quality in the Upper and Lower Floridan Aquifers ........................................51

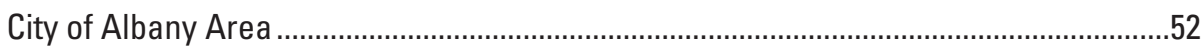

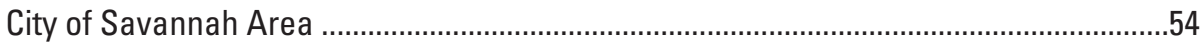

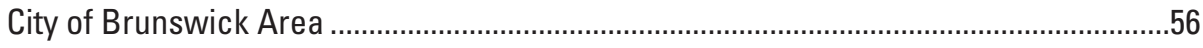

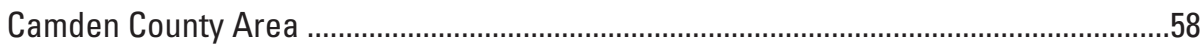

Selected Ground-Water Studies in Georgia, 2006-2007..........................................................61

Ground-Water Monitoring Program for the Augusta-Richmond County Area .......................62

Geohydrology of Fractured Crystalline Rock of Northern Georgia ........................................64

City of Albany Cooperative Water Program ………………...............................................66

City of Brunswick and Glynn County Cooperative Water Program ...........................................68 
Selected Ground-Water Studies in Georgia, 2006-2007-Continued

Georgia Coastal Sound Science Initiative 70

Hydrogeology and Impact of Pumping on Shallow Water-Bearing Zones and the Upper Floridan Aquifer, South-Central Georgia..

Geohydrology and Effects of Climate and Pumpage Change on Water Resources of the Aucilla-Suwannee-Ochlockonee River Basin, South-Central Georgia and Adjacent Areas of Florida.

Ground-Water Information and Project Support

Simulation and Particle-Tracking Analysis of Selected Ground-Water Pumping Scenarios at Vogtle Electric Generation Plant, Burke County, Georgia . .78

Monitoring of Ground-Water and Surface-Water Resources in the City of Lawrenceville Area.

U.S. Geological Survey U.S. Air Force Plant 6 Remediation Assistance Program ...................82

Selected Ground-Water Publications, Conferences, and Outreach, 2006-2007.............................84

Georgia Water-Resources Conference for 2007................................................................

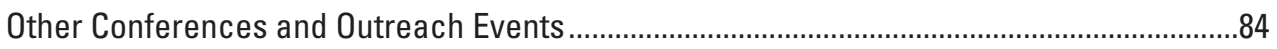

Selected U.S. Geological Survey Reports and Conference Proceedings Articles ..................84

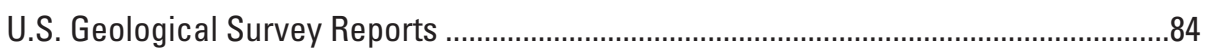

2007 Georgia Water Resources Conference Proceedings Papers ..................................85 


\section{Conversion Factors and Datums}

\begin{tabular}{lll}
\hline \multicolumn{1}{c}{ Multiply } & \multicolumn{1}{c}{ By } & \multicolumn{1}{c}{ To obtain } \\
\hline inch & \multicolumn{1}{c}{ Length } & \\
inch & 2.54 & centimeter $(\mathrm{cm})$ \\
foot (ft) & 25.4 & millimeter $(\mathrm{mm})$ \\
mile (mi) & 0.3048 & meter $(\mathrm{m})$ \\
yard (yd) & 1.609 & kilometer $(\mathrm{km})$ \\
& 0.9144 & meter $(\mathrm{m})$ \\
\hline gallon per minute $(\mathrm{gal} / \mathrm{min})$ & Flow rate & \\
gallon per day (gal/d) & 0.06309 & liter per second $(\mathrm{L} / \mathrm{s})$ \\
million gallons per day (Mgal/d) & 0.003785 & cubic meter per day $\left(\mathrm{m}^{3} / \mathrm{d}\right)$ \\
\hline
\end{tabular}

Vertical coordinate information is referenced to the North American Vertical Datum of 1988 (NAVD 88). Historical data collected and stored as National Geodetic Vertical Datum of 1929 have been converted to NAVD 88 for use in this publication.

Horizontal coordinate information is referenced to the North American Datum of 1983 (NAD 83). Historical data collected and stored as North American Datum of 1927 (NAD 27) have been converted to NAD 83 for use is in this publication.

Altitude, as used in this report, refers to distance above the vertical datum.

Specific conductance is given in microsiemens per centimeter at 25 degrees Celsius $\left(\mu \mathrm{S} / \mathrm{cm}\right.$ at $\left.25^{\circ} \mathrm{C}\right)$.

Concentrations of chemical constituents in water are given either in milligrams per liter (mg/L) or micrograms per liter ( $\mu \mathrm{g} / \mathrm{L})$. 



\title{
Ground-Water Conditions and Studies in Georgia, 2006-2007
}

\author{
by Michael F. Peck, Jaime A. Painter, and David C. Leeth
}

\section{Abstract}

The U.S. Geological Survey collects ground-water data and conducts studies to monitor hydrologic conditions, better define ground-water resources, and address problems related to water supply, water use, and water quality. Water levels were monitored continuously, in Georgia, in a network of 184 wells during 2006 and 182 wells during 2007. Because of missing data or the short period of record (less than 3 years) for several of these wells, a total of 166 wells from the network are discussed in this report. These wells include 18 in the surficial aquifer system, 21 in the Brunswick aquifer system and equivalent sediments, 67 in the Upper Floridan aquifer, 15 in the Lower Floridan aquifer and underlying units, 10 in the Claiborne aquifer, 1 in the Gordon aquifer, 11 in the Clayton aquifer, 12 in the Cretaceous aquifer system, 2 in Paleozoic-rock aquifers, and 9 in crystalline-rock aquifers. Data from the network indicate that water levels generally declined from 2005 levels, with water levels in 99 wells below normal, 52 wells in the normal range, 12 wells above normal, and 3 wells with insufficient data for comparison of 5-year trends and period of record statistics.

In addition to continuous water-level data, periodic synoptic water-level measurements were collected and used to construct potentiometric-surface maps for the Upper Floridan aquifer in Camden, Charlton, and Ware Counties, Georgia, and adjacent counties in Florida during September 2006 and 2007, in the Brunswick area during July 2006 and August 2007, and in the City of Albany-Dougherty County area during October 2006 and October 2007. In general, the configuration of the potentiometric surfaces showed little change during 2006-2007 in each of the areas.

Ground-water quality in the Upper Floridan aquifer is monitored in the Albany, Savannah, and Brunswick areas and in Camden County; and water quality in the Lower Floridan aquifer is monitored in the Savannah and Brunswick areas and in Camden County. In the Albany area, nitrate concentrations generally have increased since the end of the drought during 2002. During 2006, water from two wells had nitrate as N concentrations above the U.S. Environmental Protection Agency's (USEPA) 10-milligram-per-liter (mg/L) drinking-water standard. During 2007, only one well had concentrations above the drinking-water standard.

In the Savannah area, measurement of fluid conductivity and chloride concentration in water samples from discrete depths in three wells completed in the Upper Floridan aquifer and one well in the Lower Floridan aquifer were used to assess changes in water quality in the Savannah area. At Tybee Island, chloride concentrations in samples from the Lower Floridan aquifer decreased during 2006-2007 but were still above the 250-mg/L USEPA drinking-water standard. At Skidaway Island, water in the Upper Floridan aquifer is fresh, and chloride concentrations did not appreciably change during 2006-2007. However, chloride concentrations in samples collected from the Lower Floridan aquifer during 2006-2007 showed disparate changes; whereby, chloride concentration increased in the shallowest sampled interval (900 feet) and decreased slightly in a deeper sampled interval (1,070 feet). At Fort Pulaski, water samples collected from the Upper Floridan aquifer were fresh and did not appreciably change during 2006-2007.

In the Brunswick area, maps showing the chloride concentration of water in the Upper Floridan aquifer were constructed by using data collected from 29 wells during July 2006 and from 26 wells during August 2007. Analyses indicate that concentrations remained above the USEPA drinking-water standard in an approximate 2-square-mile area. During 2006-2007, chloride concentrations increased in only three of the wells sampled and ranged from 4.0 to $20 \mathrm{mg} / \mathrm{L}$ chloride.

In the Camden County area, chloride concentration during 2006-2007 was analyzed in water samples collected from eight wells, six completed in the Upper Floridan aquifer and two in the Lower Floridan aquifer. In most of the wells sampled during this period, chloride concentrations did not appreciably change; however, since the closure of the Durango Paper Mill in October 2002, chloride concentrations in the Upper Floridan aquifer near the mill decreased from a high of 184 mg/L in May 2002 to 42 mg/L in September 2007. 
Ground-water studies during 2006-2007 include

- Evaluation of ground-water flow, water quality, and water-level monitoring in the Augusta-Richmond County area;

- Evaluation of geohydrology of fractured crystalline rock of northern Georgia;

- Evaluation of ground-water flow and water quality, and water-level monitoring in the city of Albany-Dougherty County area;

- Evaluation of saltwater intrusion, water-level, and water-quality monitoring in the city of BrunswickGlynn County area;

- Evaluation of saltwater intrusion and alternative water sources as part of the Coastal Sound Science Initiative;

- Evaluation of hydrogeology and effects of pumping on shallow water-bearing zones and the Upper Floridan aquifer, south-central Georgia;

- Evaluation of geohydrology and effects of climate and pumpage change on water resources of the AucillaSuwannee-Ochlockonee River Basin, south-central Georgia and adjacent areas of Florida;

- Collection of ground-water data in and adjacent to the State of Georgia;

- Simulation and particle-tracking analysis of selected ground-water pumping scenarios at Vogtle Electric Generation Plant, Burke County, Georgia;

- Assessment of the sustainability of ground-water resources in the City of Lawrenceville area; and

- Participation in the U.S. Air Force Plant 6 remediation assistance program.

\section{Introduction}

Reliable and impartial scientific information on the occurrence, quantity, quality, distribution, and movement of water is essential to resource managers, planners, and others throughout the Nation. The U.S. Geological Survey (USGS) - in cooperation with numerous local, State, and Federal agencies - collects hydrologic data and conducts studies to monitor hydrologic conditions and better define the water resources of Georgia and other States and territories.

Ground-water-level and ground-water-quality data are essential for water-resource assessment and management. Water-level measurements from observation wells are the principal source of information about the hydrologic stresses on aquifers and how these stresses affect ground-water recharge, storage, and discharge. Long-term, systematic measurements of water levels provide essential data needed to evaluate changes in the resource over time, develop groundwater models and forecast trends, and design, implement, and monitor the effectiveness of ground-water management and protection programs (Taylor and Alley, 2001). Ground-waterquality data are necessary for the protection of ground-water resources because deterioration of ground-water quality may be virtually irreversible, and treatment of contaminated ground water can be expensive (Alley, 1993). Reliable water-use data are important to many organizations and individuals in support of research and policy decisions and are essential in understanding the effects of humans on the hydrologic system (Hutson and others, 2004). 


\section{Purpose and Scope}

This report presents an overview of ground-water conditions, water-use information, and hydrologic studies conducted during 2006-2007 by the USGS in Georgia. Summaries are presented for selected ground-water studies along with objectives and progress. These summaries include

- Publication of permitted water-use data for the State during 2005, and ground-water-use trends for 2003-2007;

- Evaluation of ground-water flow, water quality, and water-level monitoring in the Augusta-Richmond County area;

- Evaluation of geohydrology of fractured crystalline rock of northern Georgia;

- Evaluation of ground-water flow and water quality, and water-level monitoring in the city of Albany-Dougherty County area;

- Evaluation of saltwater intrusion, water-level, and water-quality monitoring in the city of BrunswickGlynn County area;

- Evaluation of saltwater intrusion and alternative water sources as part of the Coastal Sound Science Initiative;

- Evaluation of hydrogeology and effects of pumping on shallow water-bearing zones and the Upper Floridan aquifer, south-central Georgia;

- Evaluation of geohydrology and effects of climate and pumpage change on water resources of the AucillaSuwannee-Ochlockonee River Basin, south-central Georgia and adjacent areas of Florida;

- Collection of ground-water data in and adjacent to the State of Georgia;

- Simulation and particle-tracking analysis of selected ground-water pumping scenarios at Vogtle Electric Generation Plant, Burke County, Georgia;

- Assessment of the sustainability of ground-water resources in the City of Lawrenceville area;

- Participation in the U.S. Air Force Plant 6 remediation assistance program; and

- Publication of reports on ground-water conditions in Georgia (listed on page 4).

Water-use data compiled for 2003-2007 and reported herein are based on State-mandated reporting requirements for water users withdrawing more than 100,000 gallons per day (gal/d). State-mandated reporting includes data for public supply, industrial and commercial, and thermoelectric-power water use; however, reporting of information on irrigation water use is not mandated and, therefore, not discussed in this report.
Continuous water-level measurements were obtained from 184 wells during 2006 and 182 wells during 2007 (however, data from only 166 wells are summarized herein). Of the 182 wells equipped with continuous water-level recorders during 2007, 153 wells had electronic data recorders, which recorded the water level at 60-minute intervals, and the data generally were retrieved bimonthly. Twenty-nine wells had real-time satellite telemetry, which recorded the water level at 60-minute intervals, and three of the sites were equipped to monitor specific conductance. Real-time data are transmitted every 1 to 4 hours (based on equipment) for display on the USGS Georgia Water Science Center Web site at http://water.usgs.gov/ga/nwis/current?type $=g w /$.

Median-annual water levels for 2007 were compared with the normal range of ground-water levels for the period of record; results of this comparison are shown on maps for selected aquifers and areas of the State. In addition, hydrographs showing monthly mean ground-water levels for the period 2003-2007 are shown with period-of-record water-level statistics for selected wells.

Periodic synoptic water-level measurements in the Upper Floridan aquifer were collected in 68 and 70 wells during October 2006 and October 2007, respectively, in southcentral Dougherty County near Albany; maps showing the potentiometric surface of the aquifer were constructed from these data. A similar map of the Upper Floridan aquifer was constructed for Camden, Charlton, and Ware Counties and adjacent counties in Florida by using water-level measurements collected during September 2006 and 2007 (Kinnaman and Dixon, 2007, 2008).

The quality of ground water from the Upper and Lower Floridan aquifers is being monitored in Albany and in several areas along the coast of Georgia. Water from the Upper Floridan aquifer was analyzed for nitrate concentrations in 13 wells during November 2006 and in 12 wells during October 2007 in south-central Dougherty County near Albany.

In the city of Savannah, ground-water quality was assessed by using a combination of fluid resistivity logs and depthdependent "grab" samples instread of the more traditional water-quality collection method of purging and sampling a well, as is done in the city of Brunswick and in Camden County. In Savannah, four wells were assessed during December 2006 and 2007 using this technique.

Chloride concentrations in water collected from the Upper and Lower Floridan aquifers are presented in graphs for five wells in the city of Brunswick area and for eight wells in the Camden County area. Maps were constructed showing the chloride concentrations in water from the upper water-bearing zone of the Upper Floridan aquifer at Brunswick for July 2006 and August 2007. 
Ground-Water Conditions and Studies in Georgia, 2006-2007

Previously published U.S. Geological Survey reports on ground-water conditions in Georgia.

[OFR, Open-File Report; WRIR, Water-Resources Investigations Report; SIR, Scientific Investigations Report]

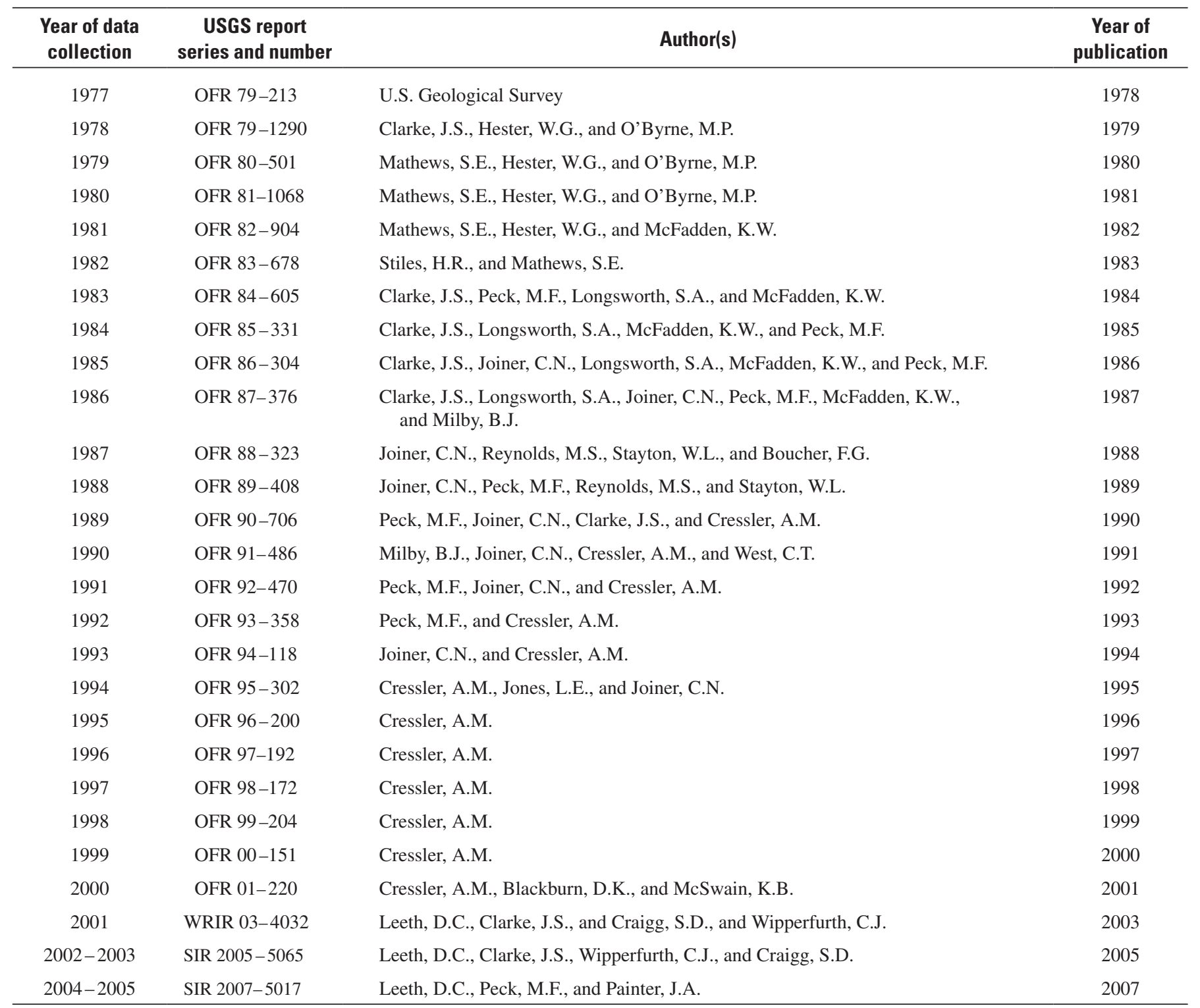




\section{Methods of Analysis, Sources of Data, and Data Accuracy}

Hydrographs from selected wells are presented herein to compare 5-year trends and seasonal fluctuations to periodof-record statistics in major aquifers throughout Georgia. Additional well information can be obtained from the USGS National Water Information System (NWIS) at http://water data.usgs.gov/ga/nwis/gw/.

Median water levels for 2007 were compared to period-ofrecord normal water levels to determine if water levels were above normal, below normal, or normal. For these comparisons the period of record must be greater than 3 years. In this report, the normal range is defined as water-level observations during the calendar year that were between the 25th and 75th percentiles (first and third quartiles), also known as the interquartile range, for the period of record. The 75th percentile (third quartile) means that three-quarters of the observations lie below it; the 25th percentile (first quartile) means that onequarter of the observations lie below it, and the median or 50th percentile (second quartile) means that two-quarters (one-half) of the observations lie below it and two-quarters (one-half) of the observations lie above it (Hamburg, 1985). The normal range can be shown by examining a graphical representation of these values known as a boxplot (Tukey, 1977; below).

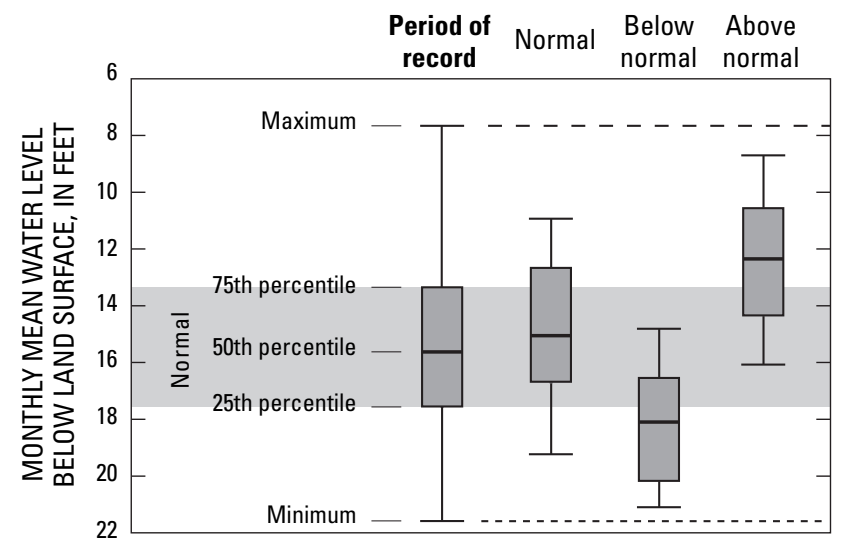

Boxplot depicting the method used to determine if 2007 water levels in a well were within, below, or above the normal range. If the median (50th percentile) water level for 2007 was between the 25th and 75th percentiles of period-of-record water levels, the water level in the well was considered normal. If the median water level for 2007 was below the 25th percentile, the water level in the well was considered below normal. If the median water level for 2007 was above the 75th percentile, the water level was considered above normal.
The results of this comparison are graphically represented on maps in the ground-water-level section of this report either by an arrow pointing upward for 2007 monthly mean water levels above period-of-record normal values, an arrow pointing downward for 2007 monthly mean water levels below the normal range for the period of record, or a circle for 2007 monthly mean water levels within the normal range for the period of record (see map below for example).

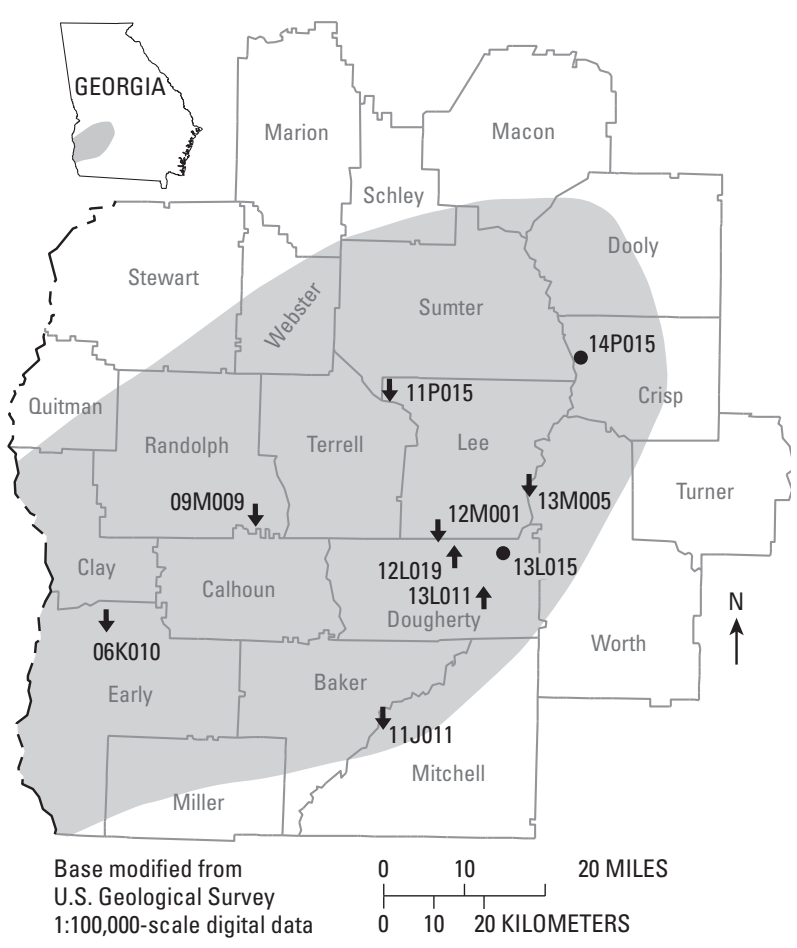

\section{EXPLANATION}

Claiborne aquifer

Observation well, site name, and comparison of monthly mean water level during 2007 to period-of-record water level

13L011 Above normal—Above 75th percentile water level for period of record

-14P015 Normal-Between 25th and 75th percentile water levels for period of record

$\downarrow_{13 \text { M005 }}$ Below normal-Below 25th percentile water level for period of record

Results of the comparison between period-of-record water levels and 2007 water levels in wells continuously monitored in the Claiborne aquifer by the USGS. A circle represents water level in a well that is within the normal range (normal). An arrow pointing upward represents water level in a well that is above the normal range (above normal). An arrow pointing downward represents water level in a well that is below the normal range (below normal). 
Data showing monthly mean ground-water levels during 2003-2007 were plotted with data showing period-of-record water-level statistics (monthly mean normal, minimum, and maximum water levels; see hydrograph below). The period-of-record monthly statistics were calculated through December 2006 and are repeated on the graphs for 5 consecutive years. Land-surface altitude for most wells was determined from topographic maps and is accurate to about one-half the contour interval (usually from 2.5 to 5 feet). Some land-surface altitudes were determined by surveying methods or global positioning system (GPS) and are more accurate.

Water samples were analyzed for nitrate at the USGS laboratory in Denver, Colorado. Chloride analyses were conducted at the St. Johns River Water Management District in Palatka, Florida (for Camden County), and at TestAmerica Laboratory, Savannah, Georgia. Additional water-quality data for Georgia can be obtained from the USGS NWIS at http://waterdata. usgs.gov/ga/nwis/qw/.

The Georgia Water-Use Program (GWUP) — a cooperative project between the USGS and the Georgia Department of Natural Resources, Environmental Protection Division-has documented the use of water in the State since 1977. Wateruse data compiled by various Federal, State, and local agencies are combined into a centralized database known as the Georgia Water-Use Data System (GWUDS). The GWUDS contains permitted water-use information on public supplies, industrial and commercial supplies, and thermoelectric-power and hydroelectric-power uses for 1980-2005. Georgia water law requires a withdrawal permit for all public-supply, industrial, and other water users who withdraw more than 100,000 gal/d. An exception to this requirement is for irrigation water. During 1988, the Georgia Legislature enacted a permitting law for irrigation water users who withdraw more than 100,000 gal/d, but the reporting of water withdrawal is not required.

\section{Georgia Well-Naming System}

Wells described in this report are assigned a well name according to a system based on the index of USGS 7.5-minute topographic maps of Georgia. Each map in Georgia has been assigned a two- to three-digit number and letter designation (for example, $07 \mathrm{H}$ ) beginning at the southwestern corner of the State. Numbers increase sequentially eastward, and letters advance alphabetically northward. Quadrangles in the northern part of the State are designated by double letters: AA follows $\mathrm{Z}$, and so forth. The letters "I," "O," "II," and "OO" are not used. Wells inventoried in each quadrangle are numbered consecutively, beginning with 001. Thus, the fourth well inventoried in the 11A quadrangle is designated 11A004. In the USGS NWIS database, this information is stored in the "Station Name" field; in NWIS Web, it is labeled "Site Name."

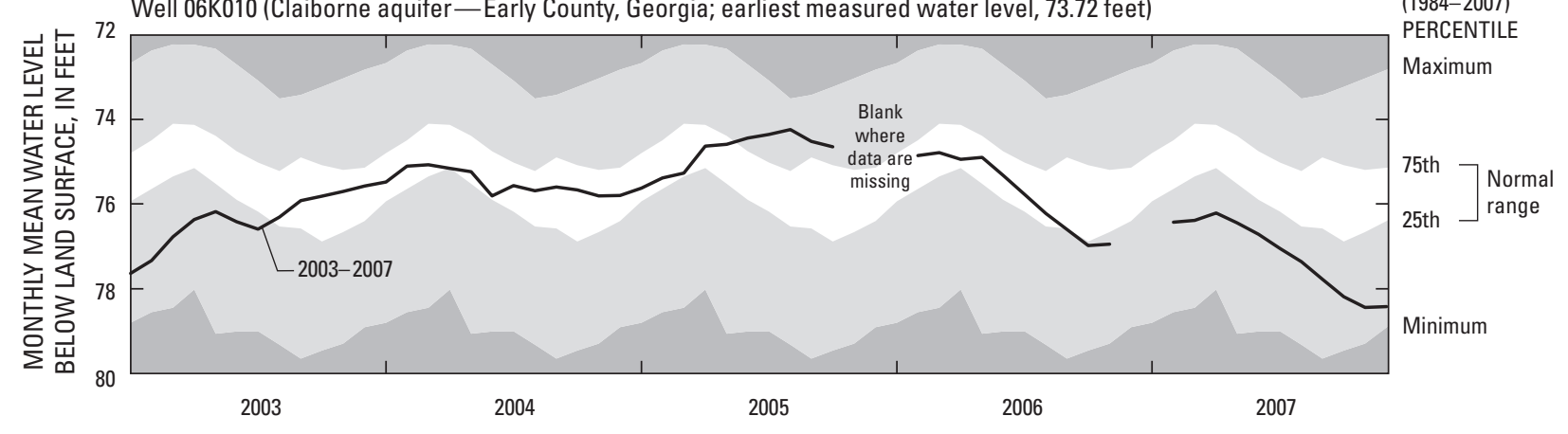

Hydrograph showing monthly mean water level in well 06K010 for the period 2003-2007 and a visual summary of water-level statistics for the period of record 1984-2007. 


\section{Cooperating Organizations and Agencies}

Ground-water monitoring and hydrologic studies in Georgia are conducted in cooperation with numerous local organizations and State and Federal agencies. Cooperating organizations and agencies include

- Department of Defense, U.S. Air Force

- Department of Defense, U.S. Army

- Georgia Department of Agriculture

- Georgia Department of Natural Resources Environmental Protection Division

- St. Johns Water Management District (Florida)

- Jekyll Island Authority

- Flint River Water Planning and Policy Center

- Albany Water, Gas, and Light Commission

- Camden County

- Glynn County

- Lee County

- Liberty County Development Authority

- McIntosh County

- City of Brunswick

- City of Lawrenceville

With the exception of the Federal agencies, all of these organizations participate in the USGS Cooperative Water Program, an ongoing partnership between the USGS and State of local agencies. The program enables joint planning and funding for systematic studies of water quantity, quality, and use. Data obtained from these studies are used to guide water-resources management and planning activities and provide indications of emerging water problems. For a more complete description of the Cooperative Water Program, see Brooks (2001).

\section{References Cited}

Alley, W.M., 1993, General design consideration, in Alley, W.M., ed., Regional ground-water quality: New York, N.Y., Van Nostrand Reinhold, 634 p.

Brooks, M.H., 2001, Cooperative Water Program-A partnership in the Nation's water-resources program: U.S. Geological Survey Fact Sheet 128-01, 2 p.

Hamburg, Morris, 1985, Basic statistics: Atlanta, Ga., Harcourt, Brace, Jovanovich, 548 p.

Hutson, S.S., Barber, N.L., Kenny, J.F., Linsey, K.S., Lumia, D.S., and Maupin, M.A., 2004, Estimated use of water in the United States in 2000: U.S. Geological Survey Circular 1268, 46 p.

Kinnaman, S.L., and Dixon, J.F., 2007, Potentiometric surface of the Upper Floridan aquifer in the St. Johns River Water Management District and vicinity, Florida, September 2006: U.S. Geological Survey Open-File Report 2007-1215, 1 sheet.

Kinnaman, S.L., and Dixon, J.F., 2008, Potentiometric surface of the Upper Floridan aquifer in the St. Johns River Water Management District and vicinity, Florida, September 2007: U.S. Geological Survey Open-File Report 2008-1085, 1 sheet.

Taylor, C.J., and Alley, W.M., 2001, Ground-water-level monitoring and the importance of long-term water-level data: U.S. Geological Survey Circular 1217, 68 p.

Tukey, J.W., 1977, Exploratory data analysis: Reading, Mass., Addison-Wesley Publishing, 506 p. 


\section{Ground-Water Resources}

Aquifer and well characteristics in Georgia [modified from Clarke and Pierce, 1985; Peck and others, 1992; ft, feet; gal/min, gallons per minute]

\begin{tabular}{|c|c|c|c|c|}
\hline \multirow{3}{*}{ Aquifer name } & \multirow{3}{*}{ Aquifer description } & \multicolumn{3}{|c|}{ Well characteristics } \\
\hline & & \multirow{2}{*}{$\begin{array}{c}\text { Depth }(\mathrm{ft}) \\
\text { Typical range }\end{array}$} & \multicolumn{2}{|c|}{ Yield (gal/min) } \\
\hline & & & Typical range & May exceed \\
\hline $\begin{array}{l}\text { Brunswick aquifer system, } \\
\text { including upper and } \\
\text { lower Brunswick } \\
\text { aquifers }\end{array}$ & $\begin{array}{l}\text { Phosphatic and dolomitic } \\
\text { quartz sand; generally } \\
\text { confined }\end{array}$ & $85-390$ & $10-30$ & 180 \\
\hline $\begin{array}{l}\text { Upper and Lower Floridan } \\
\text { aquifers }\end{array}$ & $\begin{array}{l}\text { Limestone, dolomite, and } \\
\text { calcareous sand; } \\
\text { generally confined }\end{array}$ & $40-900$ & $1,000-5,000$ & 11,000 \\
\hline Clayton aquifer & $\begin{array}{l}\text { Limestone and sand; } \\
\text { generally confined }\end{array}$ & $40-800$ & $250-600$ & 2,150 \\
\hline Cretaceous aquifer system & $\begin{array}{l}\text { Sand and gravel; } \\
\text { generally confined }\end{array}$ & $30-750$ & $50-1,200$ & 3,300 \\
\hline Paleozoic-rock aquifers & $\begin{array}{l}\text { Sandstone, limestone } \\
\text { and dolomite; } \\
\text { generally confined }\end{array}$ & $15-2,100$ & $1-50$ & 3,500 \\
\hline Crystalline-rock aquifers & $\begin{array}{l}\text { Granite, gneiss, schist, } \\
\text { and quartzite; } \\
\text { generally confined }\end{array}$ & $40-600$ & $1-25$ & 500 \\
\hline
\end{tabular}


Water-level fluctuations mainly are caused by variations in precipitation, evapotranspiration, and natural drainage or discharge. In addition, water levels in the city of Brunswick area are influenced by nearby pumping, precipitation, and tidal fluctuations (Clarke and others, 1990). Water levels generally rise rapidly during wet periods and decline slowly during dry periods. Prolonged droughts may cause water levels to decline below pump intakes in shallow wells, particularly those located on hilltops and steep slopes, resulting in temporary well failures. Usually, well yields are restored by precipitation (Clarke, 2003).

In the coastal area, the aquifers may respond to pumping from the Upper Floridan aquifer as a result of the hydraulic connection between the aquifers. Elsewhere the water level mainly responds to seasonal variations in recharge and discharge. In Bulloch County, unnamed aquifers equivalent to the upper and lower Brunswick aquifers are unconfined to semiconfined and are influenced by variations in recharge from precipitation and by pumping from the Upper Floridan aquifer; in the Wayne and Glynn County area, the aquifers are confined and respond to nearby pumping (Clarke and others, 1990; Clarke, 2003).

In and near outcrop areas, the aquifers are semiconfined and water levels in wells tapping the aquifers fluctuate seasonally in response to variations in recharge rate and pumping. Near the coast, where the aquifers are confined, water levels primarily respond to pumping, and fluctuations related to recharge are less pronounced (Clarke and others, 1990).

Water levels are influenced by seasonal fluctuations in recharge from precipitation, discharge to streams, and evapotranspiration (Clarke and others, 1985).

Water levels mainly are affected by precipitation and by local and regional pumping (Hicks and others, 1981). The water level is generally highest following the winter and spring rainy seasons, and lowest in the fall following the summer irrigation season.

Water levels are affected by seasonal variations in local and regional pumping (Hicks and others, 1981).

Water levels are influenced by variations in precipitation and pumping (Clarke and others, 1983, 1985).

Water levels mainly are affected by precipitation and local pumping (Cressler, 1964).

Water levels mainly are affected by precipitation and evapotranspiration, and locally by pumping (Cressler and others, 1983). Precipitation can cause a rapid rise in water levels in wells tapping aquifers overlain by thin regolith.
Primary source of water for domestic and livestock supply in rural areas. Supplemental source of water for irrigation supply in coastal Georgia.

Not a major source of water in coastal Georgia, but considered a supplemental water supply to the Upper Floridan aquifer.

Supplies about 50 percent of ground water in Georgia. The aquifer system is divided into the Upper and Lower Floridan aquifers. In the Brunswick area, the Upper Floridan aquifer includes two freshwater-bearing zones, the upper waterbearing zone and the lower water-bearing zone. The Lower Floridan aquifer is not considered a major aquifer. In the Brunswick area and in southeastern Georgia, the Lower Floridan aquifer includes the brackish-water zone, the deep freshwater zone, and the Fernandina permeable zone (Krause and Randolph, 1989). The Lower Floridan aquifer extends to more than 2,700 ft in depth and yields highchloride water below 2,300 ft (Jones and Maslia, 1994).

Major source of water for irrigation, industrial, and publicsupply use in east-central Georgia.

Major source of water for irrigation, industrial, and publicsupply use in southwestern Georgia.

Major source of water for irrigation, industrial, and publicsupply use in southwestern Georgia.

Major source of water in east-central Georgia. Supplies water for kaolin mining and processing; includes the Providence aquifer in southwestern Georgia, and the Dublin, Midville, and Dublin-Midville aquifer systems in east-central Georgia.

Not laterally extensive. Limestone and dolomite aquifers are most productive. Storage is in regolith, primary openings, and secondary fractures and solution openings in rock. Springs in limestone and dolomite aquifers discharge at rates of as much as $5,000 \mathrm{gal} / \mathrm{min}$. Sinkholes may form in areas of intensive pumping.

Storage is in regolith and fractures in rock. 


\section{Ground-Water Resources}

Contrasting geologic features and landforms of the physiographic provinces of Georgia (table, pages 8, 9; map, facing page) affect the quantity and quality of ground water throughout the State. The surficial aquifer system is present in each of the physiographic provinces. In the Coastal Plain Province, the surficial aquifer system consists of intermixed layers of sand, clay, and limestone (table, pages 8,9 ). The surficial aquifer system usually is under water-table (unconfined) conditions and is used for domestic and livestock supplies. The surficial aquifer system is semiconfined to confined locally in the coastal area. In the Piedmont, Blue Ridge, and Valley and Ridge Provinces, the surficial aquifer system consists of soil, saprolite, stream alluvium, colluvium, and other surficial deposits.

The most productive aquifers in Georgia are in the Coastal Plain Province in the southern half of the State. The Coastal Plain is underlain by alternating layers of sand, clay, dolomite, and limestone that dip and thicken to the southeast. Coastal Plain aquifers generally are confined, except near their northern limits where they crop out or are near land surface. Aquifers in the Coastal Plain include the surficial aquifer system, Brunswick aquifer system, Upper and Lower Floridan aquifers, Gordon aquifer system, Claiborne aquifer, Clayton aquifer, and Cretaceous aquifer system.

In the Valley and Ridge Province, ground water is transmitted through primary and secondary openings in folded and faulted sedimentary and metasedimentary rocks of Paleozoic age, herein referred to as "Paleozoic-rock aquifers."

In the Piedmont and Blue Ridge Provinces, the geology is complex and consists of structurally deformed metamorphic and igneous rocks. Ground water is transmitted through secondary openings along fractures, foliation, joints, contacts, or other features in the crystalline bedrock. In these provinces, aquifers are referred to as "crystalline-rock aquifers." For a more complete discussion of the State's ground-water resources, see Clarke and Pierce (1985).

\section{References}

Clarke, J.S., 2003, The surficial and Brunswick aquifer systems - alternative ground-water resources for coastal Georgia, in K.J. Hatcher, ed., Proceedings of the 2003 Georgia Water Resources Conference, April 23-24, 2003; Athens, Georgia, University of Georgia, CD-ROM.

Clarke, J.S., Brooks, Rebekah, and Faye, R.E., 1985, Hydrology of the Dublin and Midville aquifer system of east-central Georgia: Georgia Geologic Survey Information Circular 74, $62 \mathrm{p}$.

Clarke, J.S., Faye, R.E., and Brooks, Rebekah, 1983, Hydrogeology of the Providence aquifer of southwest Georgia: Georgia Geologic Survey Hydrologic Atlas 11, 5 sheets.

Clarke, J.S., Hacke, C.M., and Peck, M.F., 1990, Geology and ground-water resources of the coastal area of Georgia: Georgia Geologic Survey Bulletin 113, 106 p.

Clarke, J.S., and Pierce, R.R., 1985, Georgia ground-water resources, in U.S. Geological Survey, National Water Summary, 1984: U.S. Geological Survey Water-Supply Paper 2275, p. 179-184.

Cressler, C.W., 1964, Geology and ground-water resources of Walker County, Georgia: Georgia Geologic Survey Information Circular 29, $15 \mathrm{p}$.

Cressler, C.W., Thurmond, C.J., and Hester, W.G., 1983, Ground water in the greater Atlanta region, Georgia: Georgia Geologic Survey Information Circular 63, 144 p.

Hicks, D.W., Krause, R.E., and Clarke, J.S., 1981, Geohydrology of the Albany area, Georgia: Georgia Geologic Survey Information Circular 57, $31 \mathrm{p}$.

Jones, L.E., and Maslia, M.L., 1994, Selected ground-water data, and results of aquifer tests for the Upper Floridan aquifer, Brunswick, Glynn County, Georgia, area: U.S. Geological Survey Open-File Report 94-520, 107 p.

Krause, R.E., and Randolph, R.B., 1989, Hydrogeology of the Floridan aquifer system in southeast Georgia and adjacent parts of Florida and South Carolina: U.S. Geological Survey Professional Paper 1403-D, 65 p.

Peck, M.F., Joiner, C.N., and Cressler, A.M., 1992, Groundwater conditions in Georgia, 1991: U.S. Geological Survey Open-File Report 92-470, 137 p. 


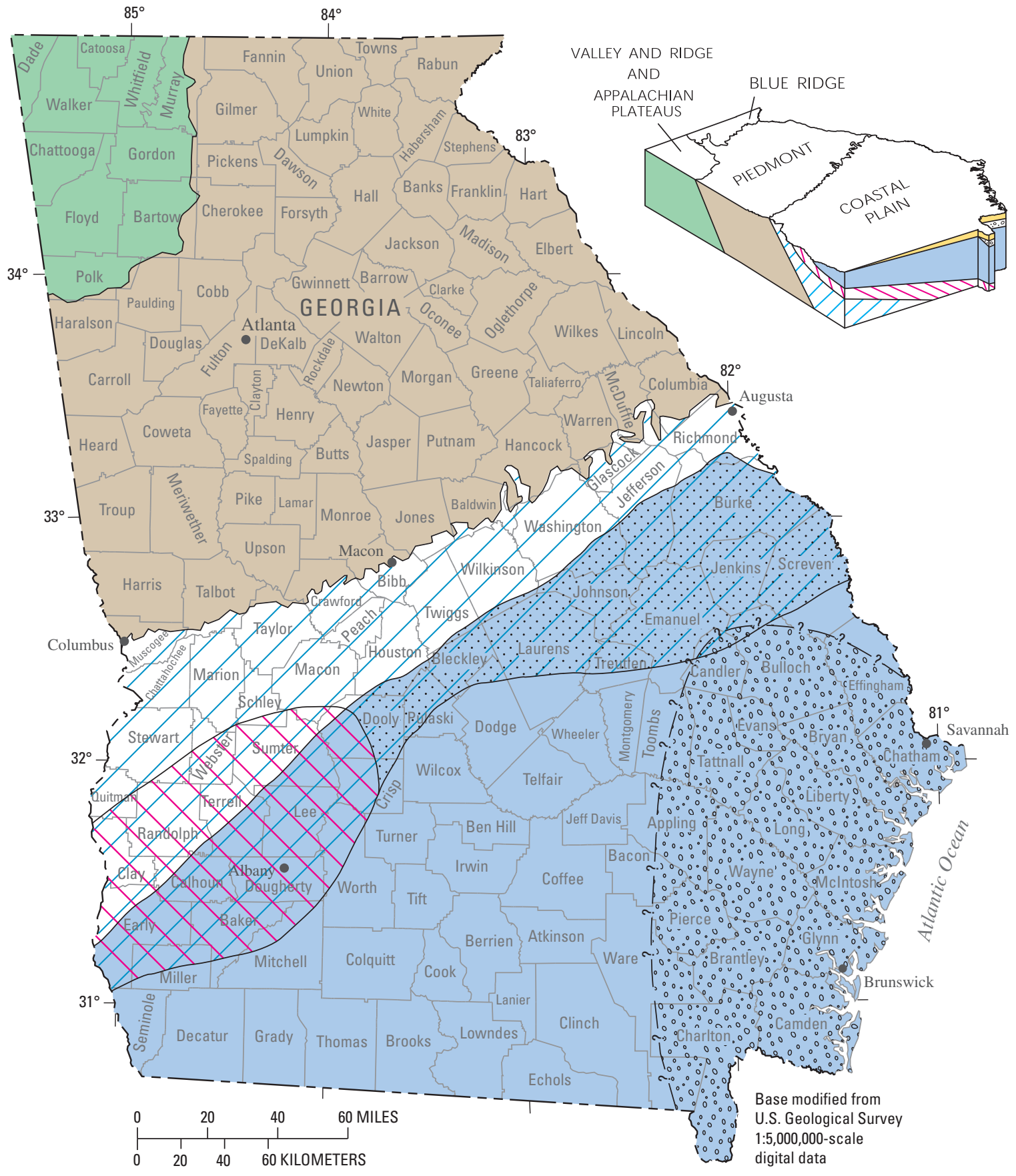

\section{EXPLANATION}

\section{Coastal Plain Province}

$\because 000$ Brunswick aquifer system

Upper and Lower Floridan aquifers

$\because: \vdots:$ Gordon aquifer system

Claiborne and Clayton aquifers

Cretaceous aquifer system
Valley and Ridge and Appalachian Plateau Provinces

Paleozoic-rock aquifers

Piedmont and Blue Ridge Provinces

Crystalline-rock aquifers

Surficial aquifer system-Present throughout State. Shown on block, not on map

Areas of use of major aquifers in Georgia (modified from Clarke and Pierce, 1985). 


\section{Permitted Water-Use Data for Georgia during 2007 and Ground-Water-Use Trends for 2003-2007}

Permitted water-use data can be used to assess the effects of ground-water withdrawal on ground-water systems. Only water-use data from permitted water systems are included in this report. Estimates are provided for public supply, industrial and commercial, and thermoelectric-power withdrawals; estimates for irrigation, livestock, and domestic use are not included (J.L. Fannning, U.S. Geological Survey, written commun., 2009). During 2007, permitted water withdrawal in Georgia totaled 4,647 million gallons per day (Mgal/d), of which 90 percent was from surface-water sources and 10 percent from ground-water sources. Permitted water withdrawal by public-supply systems totaled about 1,237 Mgal/d, of which about 82 percent was from surface-water sources and 18 percent from ground-water sources (pie charts, below). Eighteen thermoelectric plants, the largest water users in Georgia, withdrew about 2,808 Mgal/d during 2007, mostly from surface-water sources. Permitted withdrawals by industrial and commercial users totaled about $602 \mathrm{Mgal} / \mathrm{d}$, of which 60 percent was from surface-water sources and 40 percent from ground-water sources. The major industrial uses in Georgia include paper, textiles, chemicals, stone and clay, and mining.

To understand the areal distribution and trends of permitted ground-water withdrawal in the State, data from 2003 to 2007 were grouped into five areas (map and bar charts, facing page). In general, permitted ground-water withdrawal decreased slightly during 2003-2007. This decrease largely is a result of continued conservation efforts made by industrial and municipal users. In the Coastal Plain area, permitted groundwater use decreased during 2003-2007. In the eastern Coastal Plain, the decrease was about $4.37 \mathrm{Mgal} / \mathrm{d}$, mostly because of a reduction in industrial withdrawals. In the central Coastal Plain, the decrease was about $1.37 \mathrm{Mgal} / \mathrm{d}$; in the southwestern Coastal Plain, the decrease was about $2.42 \mathrm{Mgal} / \mathrm{d}$. In the Valley and Ridge area, which had decreases in ground-water withdrawals in the past, an increase of $0.5 \mathrm{Mgal} / \mathrm{d}$ occurred during 2003-2007. The Piedmont and Blue Ridge area was the only area in the State where permitted ground-water withdrawals increased during 2003-2007 by about $6 \mathrm{Mgal} / \mathrm{d}$.
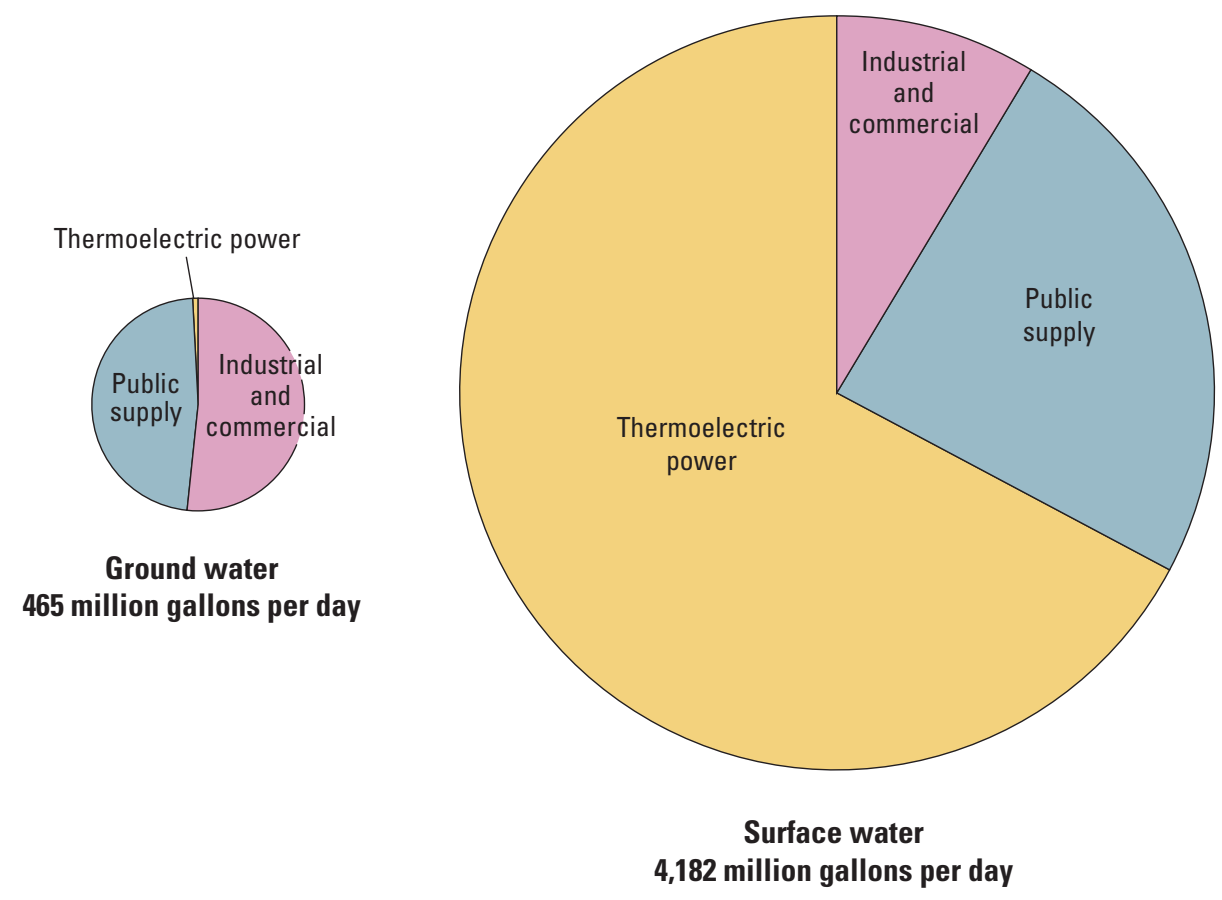

Percentages of permitted water use in Georgia by category and source, 2007. 

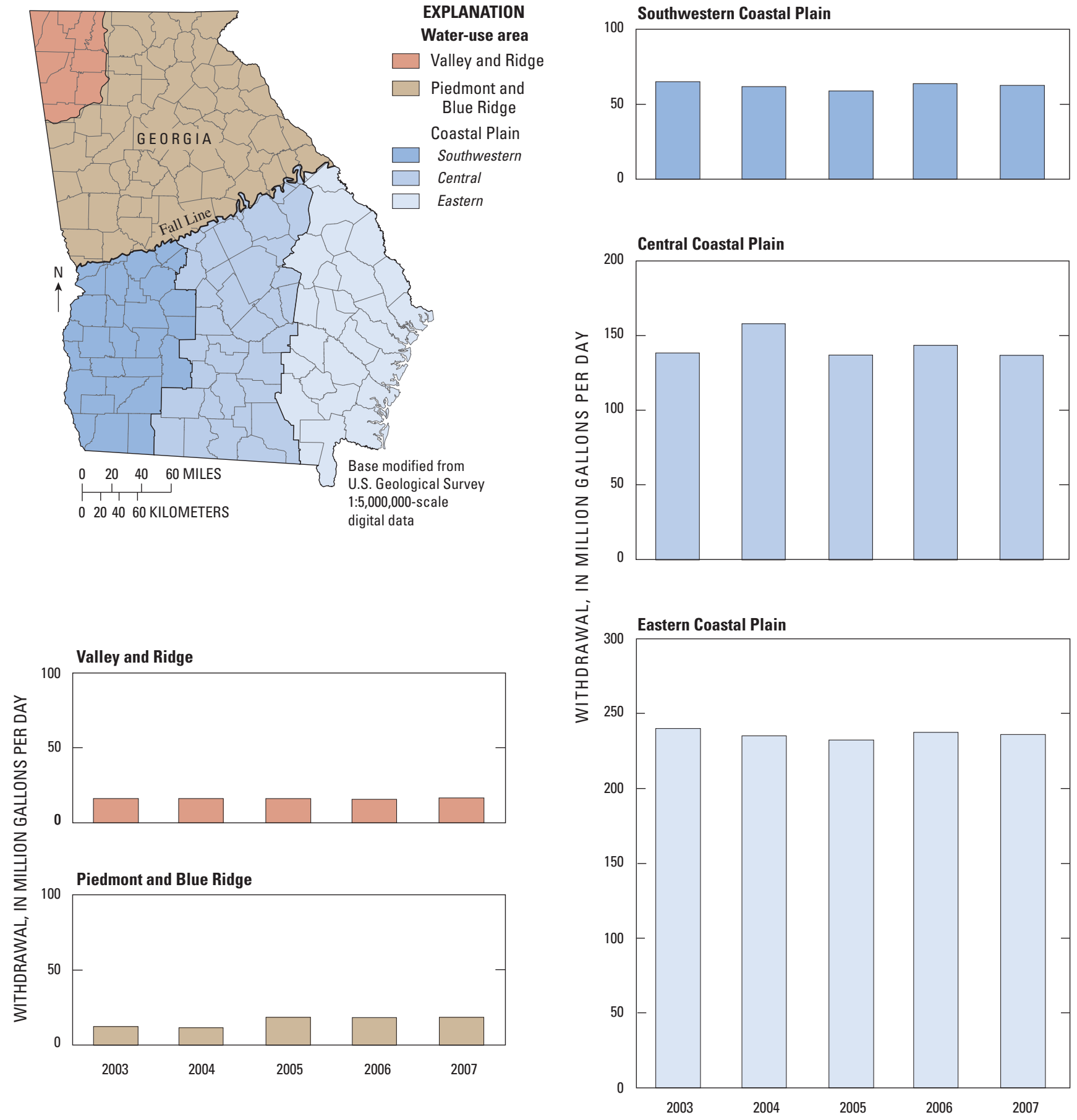

Ground-water withdrawals in Georgia by water-use area, 2003-2007. 


\section{Ground-Water Conditions}

\section{Ground-Water Levels}

Maps in this section provide an overview of ground-water levels in major aquifers in Georgia during 2007. In addition, hydrographs provide a visual summary of ground-water conditions for the past 5 years (2003-2007) compared to the period of record. Discussion of each aquifer is subdivided into areas where wells likely would have similar water-level fluctuations and trends if they were unaffected by pumping. The map on the facing page gives the locations of selected wells that were continuously monitored by the U.S. Geological Survey during the 2007 calendar year, including 29 wells that were monitored in real time.

Changes in aquifer storage cause changes in ground-water levels in wells. Taylor and Alley (2001) described many factors that affect ground-water storage; these factors are discussed briefly here. When recharge to an aquifer exceeds discharge, ground-water levels rise; when discharge from an aquifer exceeds recharge, ground-water levels decline. Recharge varies in response to precipitation and surface-water infiltration to an aquifer. Discharge occurs as natural flow from an aquifer to streams and springs, as evapotranspiration, and as withdrawal from wells. Hydraulic responses and controls on ground-water levels in major aquifers in Georgia are summarized in the table on pages 8 and 9 .
Water levels in aquifers in Georgia typically follow a cyclical pattern of seasonal fluctuation. Water levels rise during winter and spring because of increased recharge from precipitation, and water levels decline during summer and fall because of decreased recharge, greater evapotranspiration, and pumping. The magnitude of fluctuations can vary greatly from season to season and from year to year in response to varying climatic conditions. This cyclical pattern can be seen on the 5-year hydrograph of well $31 \mathrm{U} 009$ in Bulloch County (below).

Ground-water pumping is the most important human activity that affects the amount of ground water in storage and the rate of discharge from an aquifer (Taylor and Alley, 2001). As ground-water storage is depleted within the radius of influence of pumping, water levels in the aquifer decline, forming a cone of depression around the well. In areas having a high density of pumped wells, multiple cones of depression can form and produce water-level declines across a large area. These declines may alter ground-water-flow directions, reduce flow to streams, capture water from a stream or adjacent aquifer, or alter ground-water quality. The effects of sustained pumping can be seen on a hydrograph of well 07N001 in Randolph County (below).

\section{Reference}

Taylor, C.J., and Alley, W.M., 2001, Ground-water-level monitoring and the importance of long-term water-level data: U.S. Geological Survey Circular 1217, 68 p.

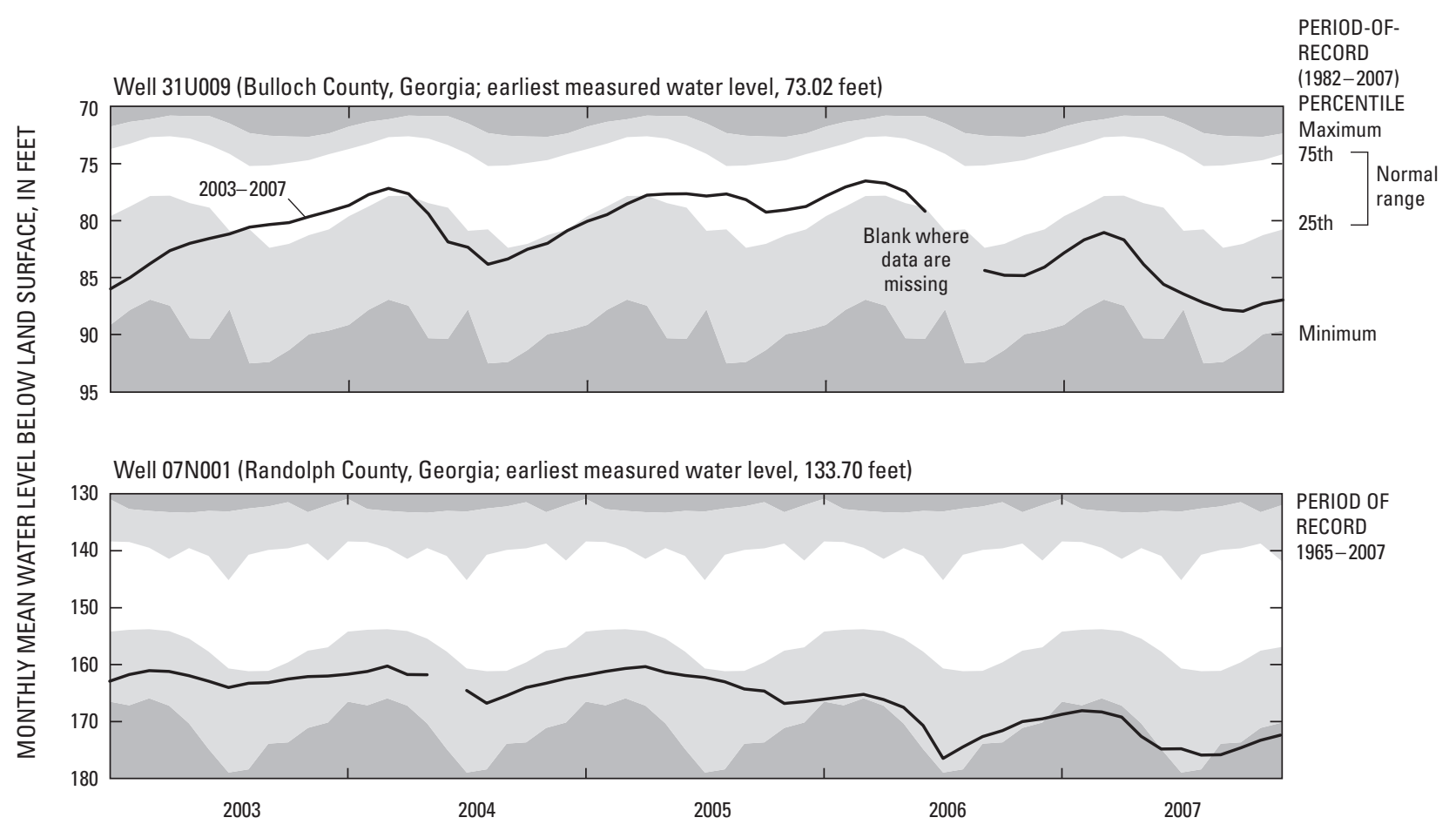

Example hydrographs showing monthly mean water levels in wells 31 U009 and 07N001 for the period 2003-2007 and summary statistics for the period of record for each well. 


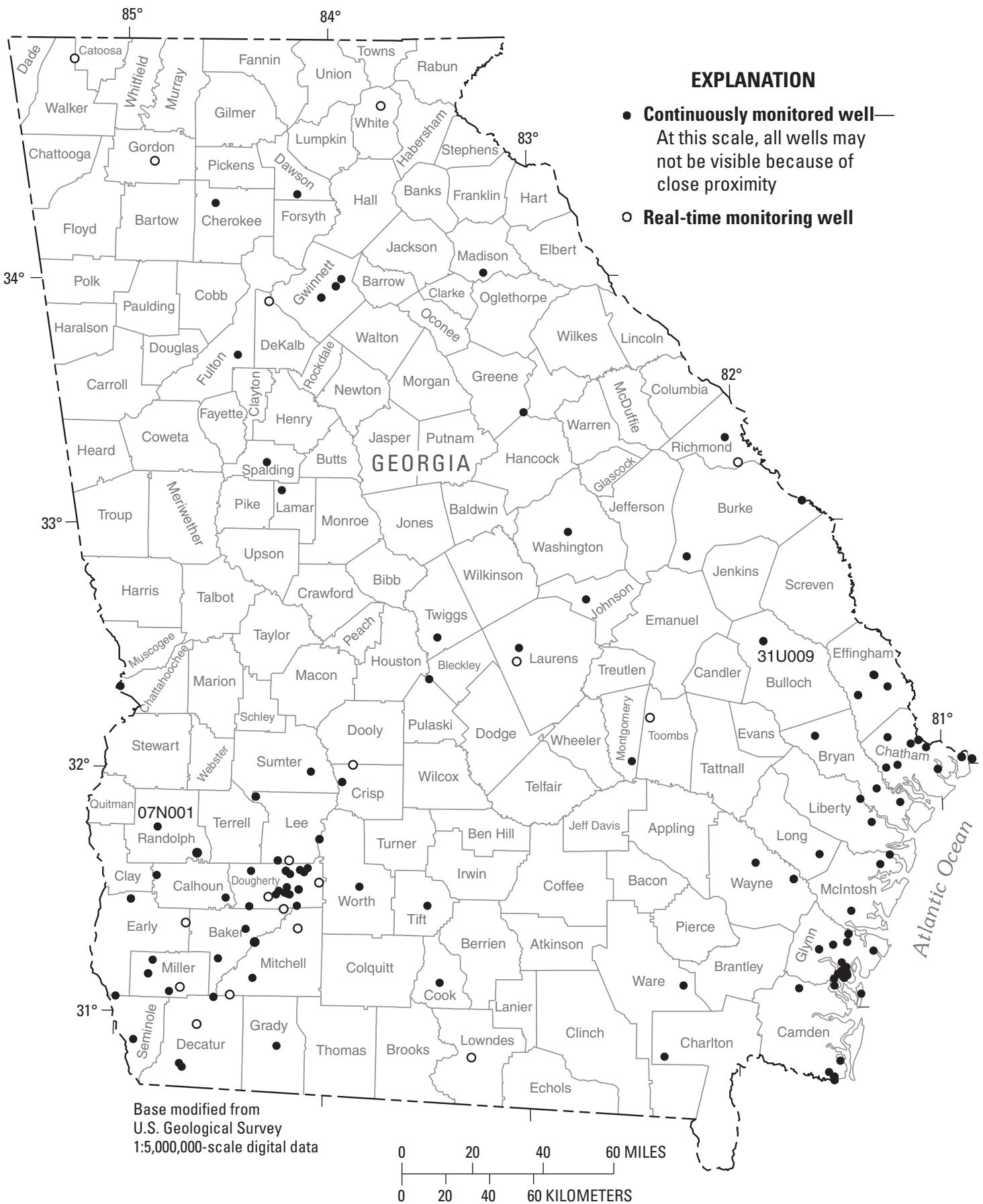

Locations of ground-water-level monitoring wells used to collect long-term water-level data in Georgia during 2007. 


\section{Ground-Water Levels}

\section{Surficial Aquifer System}

Water levels in 18 wells were used to define conditions in the surficial aquifer system during 2007 (map and table, facing page). Water in the surficial aquifer system typically is in contact with the atmosphere (referred to as an unconfined or water-table aquifer), but locally (especially in coastal Georgia) may be under pressure exerted by overlying sediments or rocks (referred to as a confined aquifer). Where unconfined, water levels change quickly in response to recharge and discharge. Consequently, hydrographs from these wells have a strong relation to climatic fluctuations.

During 2007 water levels in eight of the wells measured were within or above the normal range, below normal in nine wells, and insufficient in one well for comparison to the period of record. Water-level hydrographs for three wells completed in the surficial aquifer system (below) illustrate monthly mean water levels during 2003-2007 and period-of-record waterlevel statistics. The hydrographs show that water levels in the three wells generally rose during 2004-2005 and declined during 2006; during 2007 water levels declined in well $07 \mathrm{H} 003$ and rose in well 35P094.

The hydrograph for well 11AA01 in Spalding County in the Piedmont Province shows that the water level during 20032005 mostly was above normal but began to decline to below normal during 2006, then rose to normal in early 2007. The hydrograph for well $07 \mathrm{H003}$ in Miller County in the southwestern part of the Coastal Plain Province shows a similar but slightly different pattern in that the water level was at or above normal during most of the period under discussion but declined below normal for short periods during early 2004 and early 2005. During mid-2006 the water level was normal to slightly above normal then declined to the below-normal range during 2007. The hydrograph for well 35P094 in Chatham County in the southeastern part of the Coastal Plain Province shows a similar pattern to that of well 11AA01 in which water level was in or above the normal range during 2003, which continued through early 2007 when it was below normal before rising to the normal to above-normal range.

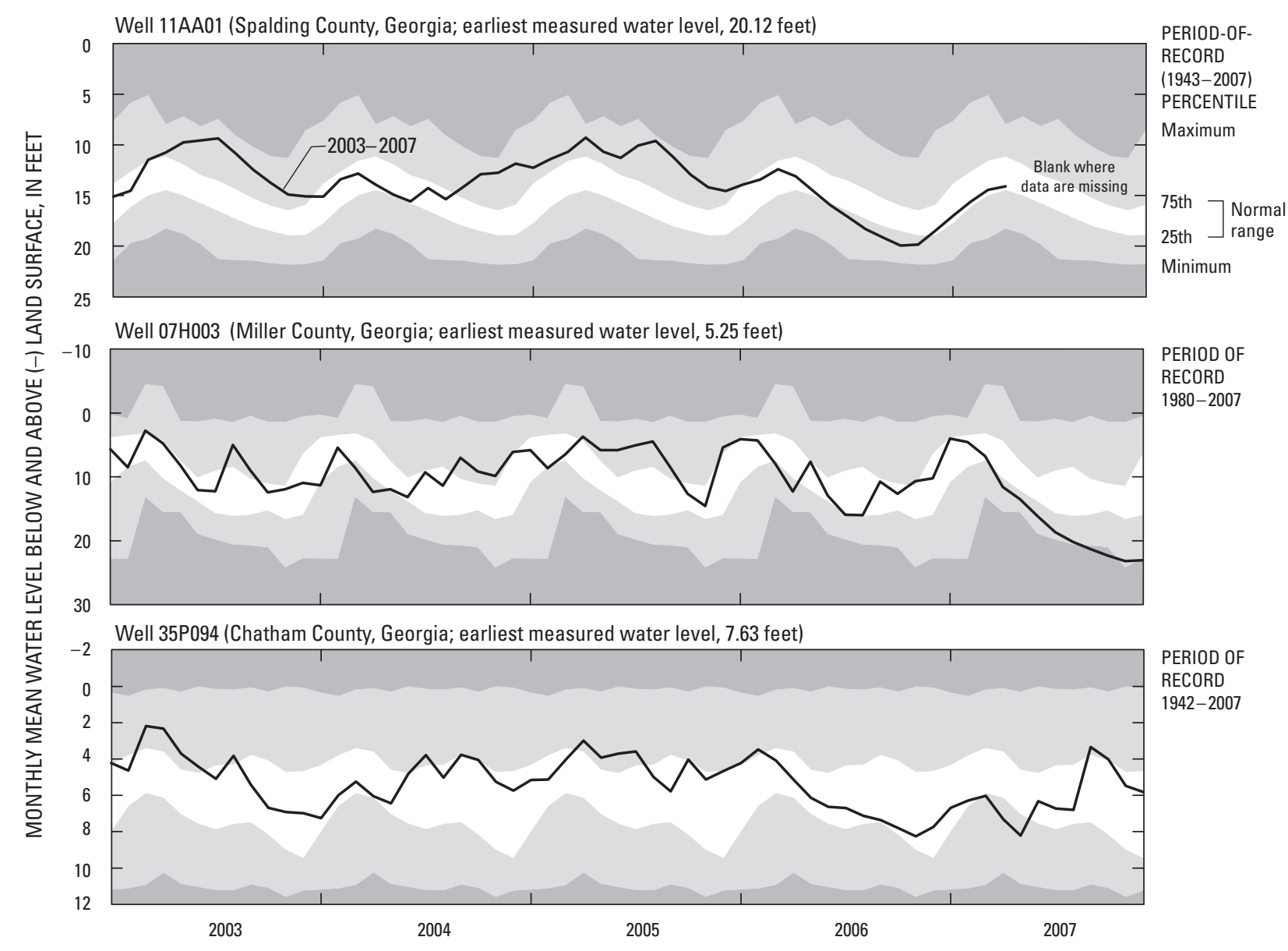




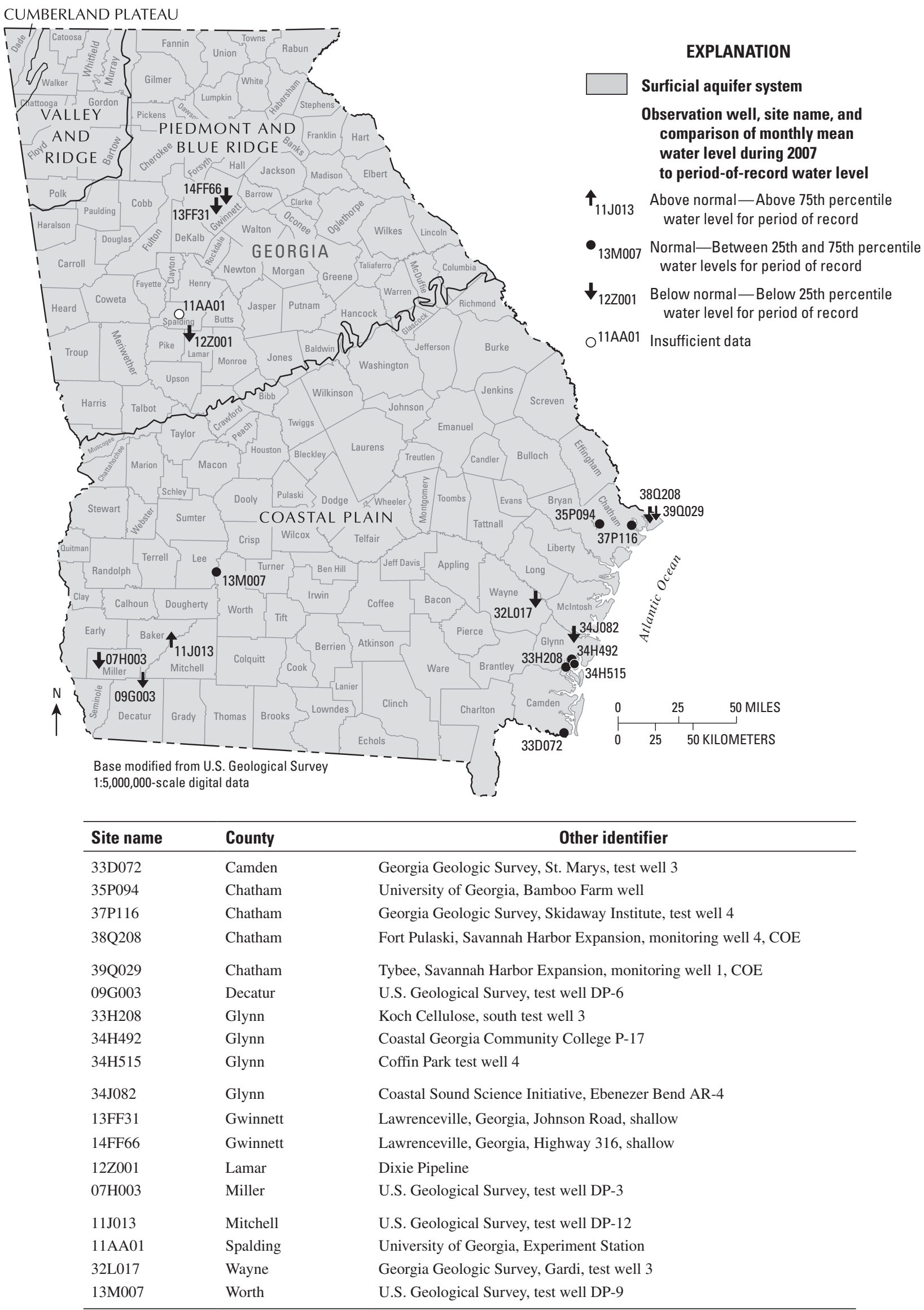




\section{Ground-Water Levels}

\section{Brunswick Aquifer System}

Water levels in 21 wells were used to define conditions in 2007 in the Brunswick aquifer system, which consists of the upper and lower Brunswick aquifers and equivalent low-permeability sediments to the north and west in southeastern Georgia. The Brunswick aquifer system is confined throughout the known area of extent (map and table, facing page). In 8 wells, water levels were in the normal range; in 1 well the water level was above the normal range; and in 12 wells, water levels were in the below-normal range. These variations reflect differences in local pumping, interaquifer-leakage effects, and recharge.

Water-level hydrographs for three wells in the Brunswick aquifer system and equivalent-sediment wells (below) illustrate monthly mean water levels during 2003-2007 and periodof-record water-level statistics. Hydrographs indicate that water levels in two of the wells rose during late 2003 through
2005 reflecting recovery from drought effects; however, water levels in all three wells declined during 2006-2007 because of a drought that began in 2006. The water level in well 31 U009 in Bulloch County (completed in undifferentiated sediments equivalent to the upper Brunswick aquifer) was normal to below normal during 2003-2007. Water levels rose during 2003 to early 2006 but had a slight decline in mid-2004 and then remained in the below-normal range from mid-2006 to the end of 2007.

The water level for well 32L016 near Jesup in Wayne County (completed in the upper Brunswick aquifer) shows the water level rose during 2003 to early 2006 from below to above normal then declined to the below-normal range by the end of 2007. The water level for well 34H437 near Brunswick in Glynn County (completed in the upper Brunswick aquifer), unlike the water levels in the other two wells, generally remained above normal from 2003 to early 2006 then declined to the normal and below-normal range by mid-2007.

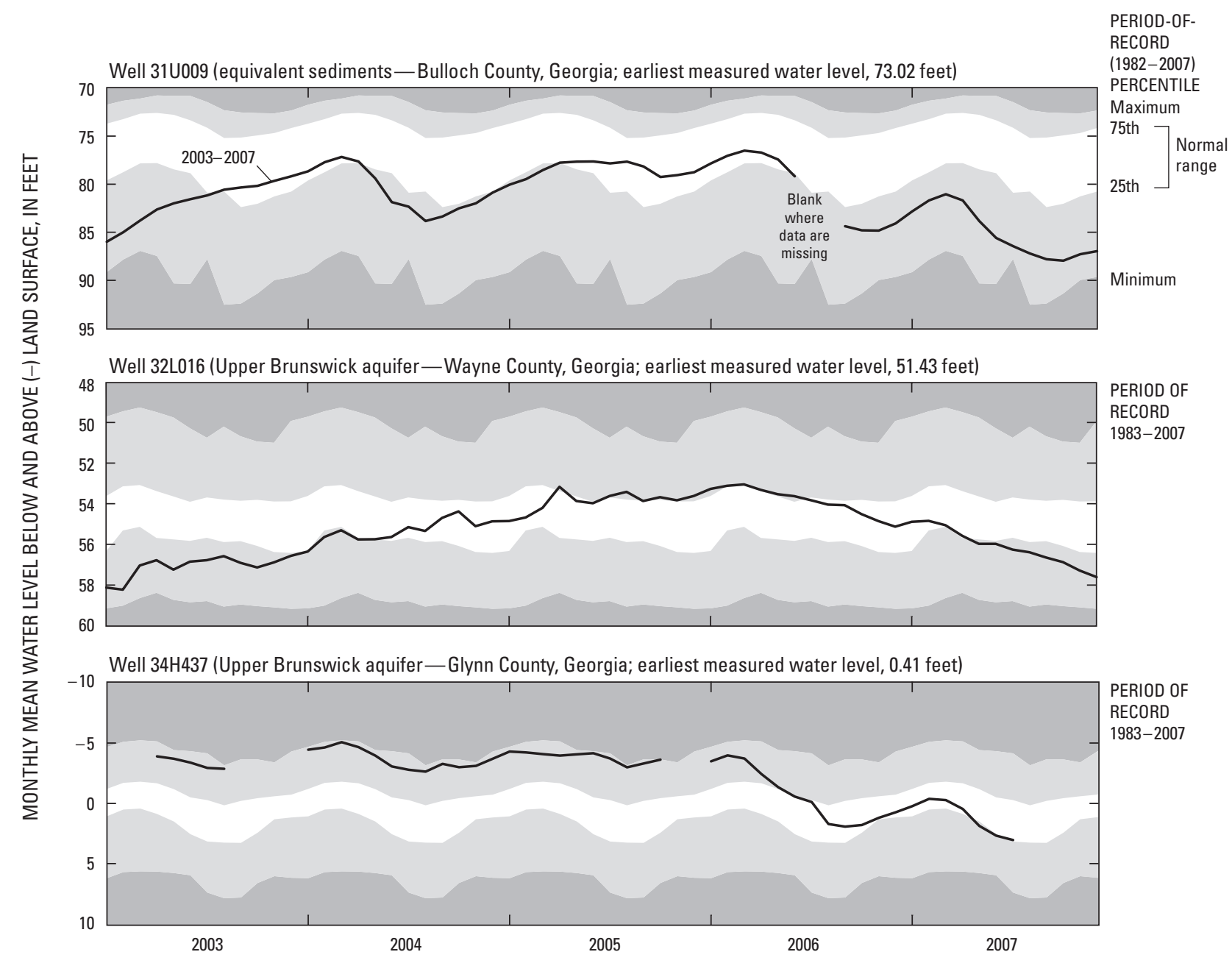



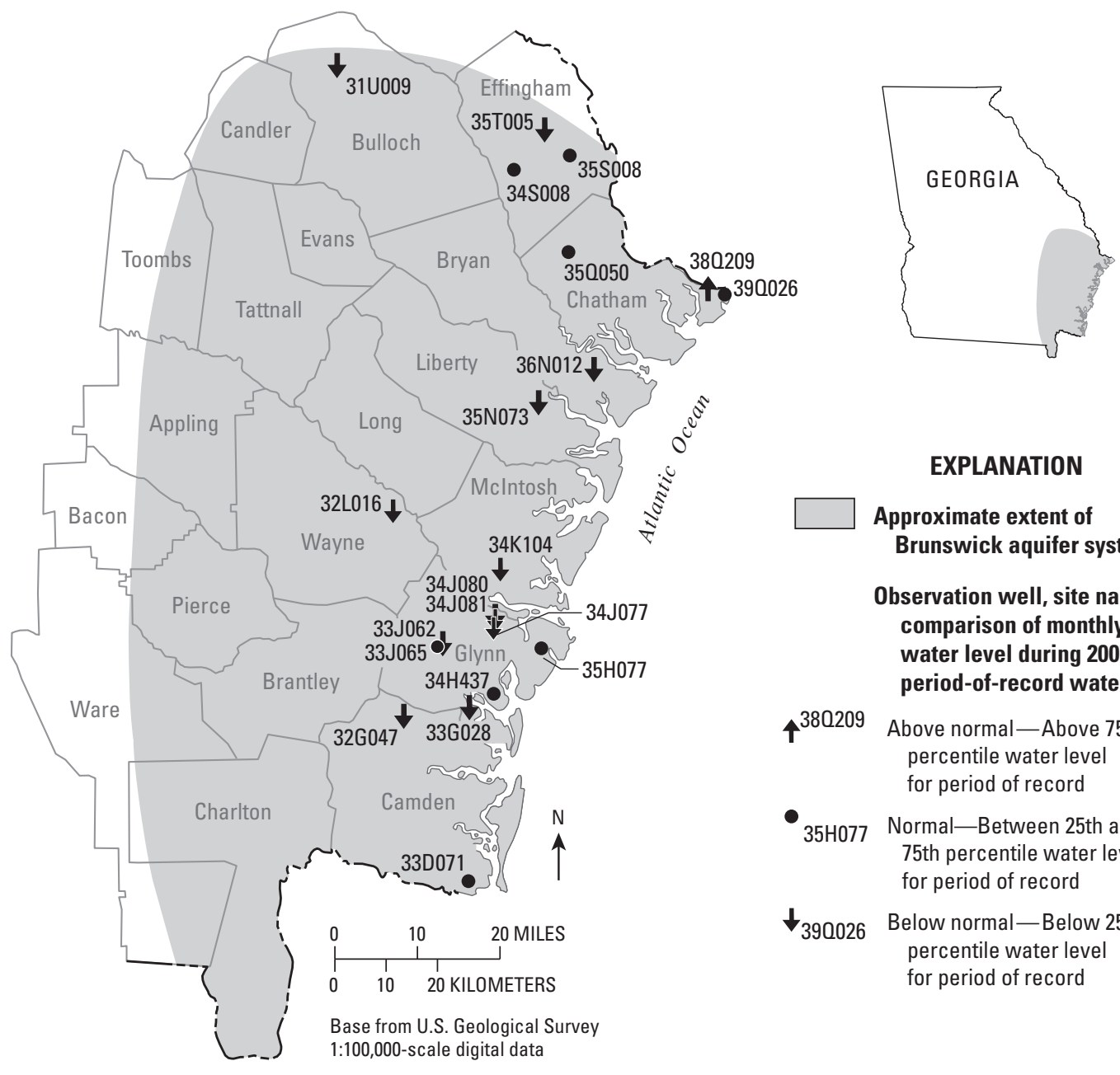

\section{EXPLANATION}

Approximate extent of Brunswick aquifer system

Observation well, site name, and comparison of monthly mean water level during 2007 to period-of-record water level

380209 Above normal-Above 75th percentile water level for period of record

35H077 Normal-Between 25th and 75th percentile water levels for period of record

$\downarrow_{390026}$ Below normal-Below 25th percentile water level for period of record

\begin{tabular}{|c|c|c|c|}
\hline Site name & $\begin{array}{c}\text { Water-bearing } \\
\text { unit }^{1}\end{array}$ & County & Other identifier \\
\hline $36 \mathrm{~N} 012$ & $\mathrm{~L}$ & Bryan & Genesis Pointe \\
\hline 31U009 & UX & Bulloch & Georgia Geologic Survey, Hopeulikit, test well 2 \\
\hline 32G047 & $\mathrm{U}$ & Camden & Waverly Firestation \\
\hline 33D071 & $\mathrm{U}$ & Camden & Georgia Geologic Survey, St. Marys, test well 2 \\
\hline 35Q050 & $\mathrm{U}$ & Chatham & Georgia Forestry Commission, test well CB-1 \\
\hline $39 \mathrm{Q} 026$ & UX & Chatham & Tybee Island, test well 3 \\
\hline 38Q209 & B & Chatham & Fort Pulaski, Savannah Harbor Expansion, monitoring well 3, COE \\
\hline $34 \mathrm{~S} 008$ & $\mathrm{LX}$ & Effingham & Pineora test well EB-1 \\
\hline $35 \mathrm{~S} 008$ & LX & Effingham & Effingham County, Georgia Geologic Survey, corehole \\
\hline 35T005 & $\mathrm{UX}$ & Effingham & Springfield, Georgia, observation well \\
\hline $33 \mathrm{G} 028$ & B & Glynn & Georgia Ports Authority, well 3 \\
\hline 33J062 & $\mathrm{L}$ & Glynn & Georgia Forestry Commission, test well GB-1 \\
\hline 33J065 & $\mathrm{U}$ & Glynn & Georgia Forestry Commission, test well GB-4 \\
\hline $34 \mathrm{H} 437$ & $\mathrm{U}$ & Glynn & Georgia Geologic Survey, Coffin Park, test well 2 \\
\hline 34J077 & $\mathrm{U}$ & Glynn & Golden Isle, test well $1 \mathrm{~S}$ \\
\hline $34 \mathrm{~J} 080$ & $\mathrm{~L}$ & Glynn & Coastal Sound Science Initiative, Ebenezer Bend AR-2 \\
\hline 34J081 & $\mathrm{U}$ & Glynn & Coastal Sound Science Initiative, Ebenezer Bend AR-3 \\
\hline $35 \mathrm{H} 077$ & $\mathrm{~L}$ & Glynn & Coastal Sound Science Initiative, St. Simons test well 2 \\
\hline $35 \mathrm{~N} 073$ & $\mathrm{~L}$ & Liberty & Old Sunbury Road OW-1 \\
\hline 34K104 & $\mathrm{L}$ & McIntosh & McIntosh County Development Authority TW-3 \\
\hline 32L016 & $\mathrm{U}$ & Wayne & Georgia Geologic Survey, Gardi, test well 2 \\
\hline
\end{tabular}

'L, lower Brunswick aquifer; UX, undifferentiated, low-permeability equivalent to the upper Brunswick aquifer; $\mathrm{U}$, upper Brunswick aquifer;

$B$, Brunswick aquifer system; LX, undifferentiated, low-permeability equivalent to the lower Brunswick aquifer. 


\section{Ground-Water Levels}

\section{Upper Floridan Aquifer}

The Upper Floridan aquifer underlies most of the Coastal Plain of Georgia, southern South Carolina, extreme southeastern Alabama, and all of Florida (Miller, 1986). The aquifer is one of the most productive in the United States, and a major source of water in the region. During 2005, about 658 million gallons per day (Mgal/d) were withdrawn from the Upper and Lower Floridan aquifers in Georgia, primarily for industrial and irrigation uses (Fanning and Trent, 2009).

The Upper Floridan aquifer predominately consists of Eocene to Oligocene limestone, dolomite, and calcareous sand. The aquifer is thinnest along its northern limit (map, facing page) and thickens to the southeast, where the maximum thickness is about 1,700 feet (ft) in Ware County (Miller, 1986). The aquifer is confined throughout most of its extent, except where it crops out or is near land surface along the northern limit, and in areas of karst topography in parts of southwestern and south-central Georgia.

The Coastal Plain of Georgia has been divided informally into four hydrologic areas for discussion of water levels (map, facing page) - the southwestern, south-central, eastcentral, and coastal areas. This subdivision is a modification of that used by Peck and others (1999) and is similar to that used by Clarke (1987).

Southwestern area. All or parts of 16 counties constitute the southwestern area. In this area, the Upper Floridan aquifer ranges in thickness from about $50 \mathrm{ft}$ in the northwest to about $475 \mathrm{ft}$ in the southeast (Hicks and others, 1987). The aquifer is overlain by sandy clay residuum, which is hydraulically connected to streams. With the introduction of center-pivot irrigation systems around 1975, the Upper Floridan aquifer has been used widely as the primary water source for irrigation in southwestern Georgia (Hicks and others, 1987).

According to Fanning and Trent (2009), about $314 \mathrm{Mgal} / \mathrm{d}$ of water was withdrawn from the Upper Floridan aquifer in the southwestern area during 2005, and 80 percent of this amount was used for irrigation.

The city of Albany-Dougherty County area lies within the southwestern area. During 2005, most of the water withdrawn from the Upper Floridan aquifer in this area was used for public-supply (about $14 \mathrm{Mgal} / \mathrm{d}$ ) and industry (14 Mgal/d; Fanning and Trent, 2009).
South-central area. Six counties constitute the south-central area. In this area, the Upper Floridan aquifer ranges in thickness from about 300 to $700 \mathrm{ft}$ (Miller, 1986). Lowndes County is a karst region, having abundant sinkholes and sinkhole lakes that have formed where the aquifer crops out and the overlying confining unit has been removed by erosion (Krause, 1979). Direct recharge from rivers to the Upper Floridan aquifer occurs through these sinkholes at a rate of about $70 \mathrm{Mgal} / \mathrm{d}$ (Krause, 1979). In the south-central area, ground-water use totaled about $91 \mathrm{Mgal} / \mathrm{d}$ in 2005, and most of this withdrawal was used for irrigation (Fanning and Trent, 2009).

East-central area. Four counties constitute the east-central area. In this area, the Upper Floridan aquifer can be as thick as $650 \mathrm{ft}$ in the southeast or absent in the north. In this area, groundwater withdrawal totaled about $15 \mathrm{Mgal} / \mathrm{d}$ during 2005 and was used predominantly for irrigation (Fanning and Trent, 2009).

Coastal area. The Georgia Environmental Protection Division (GaEPD) defines the coastal area of Georgia as a 24-county area that includes the 6 coastal counties and adjacent 18 counties - an area of about 12,240 square miles. In the coastal area, the Upper Floridan aquifer may be thin or absent in the north (Burke County) to about 1,700 ft thick in the south (Ware County; Miller, 1986). Excluding withdrawals for thermoelectric-power generation, nearly 70 percent of all withdrawals in the area are from ground water, primarily for industrial purposes. During 2005, about $308 \mathrm{Mgal} / \mathrm{d}$ of water was withdrawn from the Upper Floridan aquifer in the coastal area (Fanning and Trent, 2009).

The coastal area has been subdivided by GaEPD into three subareas - the northern, central, and southern - to facilitate implementation of the State's water-management policies. The central subarea includes the largest concentration of pumpage in the coastal area-the Savannah, Brunswick, and Jesup pumping centers. The northern subarea is northwest of the Gulf Trough (Herrick and Vorhis, 1963), a prominent geologic feature that is characterized by a zone of low permeability in the Upper Floridan aquifer that inhibits flow between the central and northern subareas. In this area, pumping from the aquifer primarily is for agricultural use, and no large pumping centers are located in the area. The southern subarea is separated from the central subarea by the Satilla line, a postulated hydrologic boundary (W.H. McLemore, Georgia Environmental Protection Division, Geologic Survey Branch, oral commun., 2000). In this area, the largest pumping center is at Fernandina Beach, Florida. 


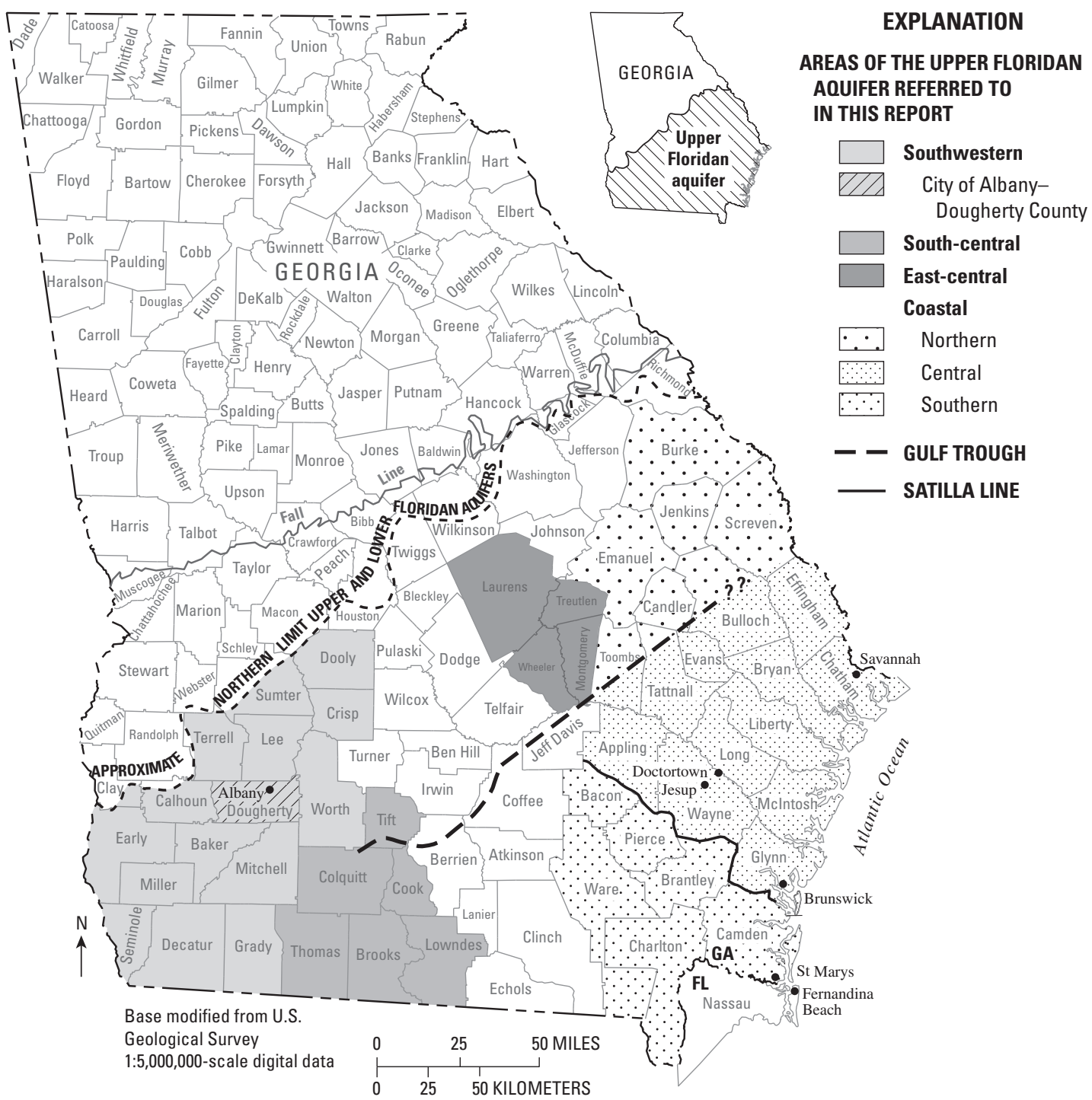

Areas of the Upper Floridan aquifer referred to in this report.

\section{References}

Clarke, J.S., 1987, Potentiometric surface of the Upper Floridan aquifer in Georgia, May 1985, and water-level trends, 1980-85: Georgia Geologic Survey Hydrologic Atlas 16, scale $1: 1,000,000,1$ sheet.

Fanning, J.L., and Trent, V.P., 2009, Water Use in Georgia by County for 2005; and Water-Use Trends, 1980-2005: U.S. Geological Survey Scientific Investigations Report 2009-5002, 186 p.; Web-only publication available at http://pubs.usgs.gov/sir/2009/5002/.

Herrick, S.M., and Vorhis, R.C., 1963, Subsurface geology of the Georgia Coastal Plain: Georgia Department of Natural Resources, Division of Mines, Mining, and Geology, Information Circular 25, $80 \mathrm{p}$.

Hicks, D.W., Gill, H.E., and Longsworth, S.A., 1987, Hydrogeology, chemical quality, and availability of ground water in the Upper Floridan aquifer, Albany area, Georgia: U.S. Geological Survey Water-Resources Investigations Report 87-4145, $52 \mathrm{p}$.

Krause, R.E., 1979, Geohydrology of Brooks, Lowndes, and western Echols Counties, Georgia: U.S. Geological Survey Water-Resources Investigations Report 78-117, 48 p.

Miller, J.A., 1986, Hydrogeologic framework of the Floridan aquifer system in Florida and parts of Georgia, Alabama, and South Carolina: U.S. Geological Survey Professional Paper 1403-B, $91 \mathrm{p}$.

Peck, M.F., Clarke, J.S., Ransom, III, Camille, and Richards, C.J., 1999, Potentiometric surface of the Upper Floridan aquifer in Georgia and adjacent parts of Alabama, Florida and South Carolina, May 1998, and water-level trends in Georgia, 1990-98: Georgia Department of Natural Resources, Environmental Protection Division, Georgia Geologic Survey, Hydrologic Atlas 22, 1 pl. 


\section{Ground-Water Levels}

\section{Upper Floridan Aquifer}

\section{Southwestern Area}

Water levels in 20 wells were used to define ground-water conditions in the Upper Floridan aquifer in southwestern Georgia during 2007 (map, facing page). In this area, water in the Upper Floridan aquifer typically is confined; however, in areas where no sediments overlie the aquifer (typically to the north and west), water is unconfined. Water levels in 14 of the 20 wells were below the normal range during 2007, and 6 wells had water levels in the normal range.

Hydrographs for three wells in the Upper Floridan aquifer in southwestern Georgia (below) illustrate monthly mean water levels during 2003-2007 and period-of-record waterlevel statistics. Water levels in all three wells declined during 2006-2007 because of the effects of a drought that began in 2006. The water level in well 09F520 in Decatur County ranged from above normal in early 2003 to below normal in early 2004, and from above normal through most of 2005 to below normal for all of 2006 and 2007, except for a few months in early 2007 when the water level was in the normal range. The water level in well 08K001 in Early County was above normal at the beginning of 2003 but declined to the below-normal range during early 2004; the water level rose during mid-2004 and remained in the normal or above-normal range through mid-2006 when the water level declined to below normal before rising to the normal range through early 2007. The water level for most of 2007 was in the belownormal range. The water level in well 15L020 in Worth County has had a downward trend for most of the period of record. The rate of this downward trend increased during early 1999 and continued through most of 2002 when the water level in this well reached a record low. The water level rose slightly during 2003-2005 but was still below normal through 2006-2007; a new record-low water level was recorded during late 2007.

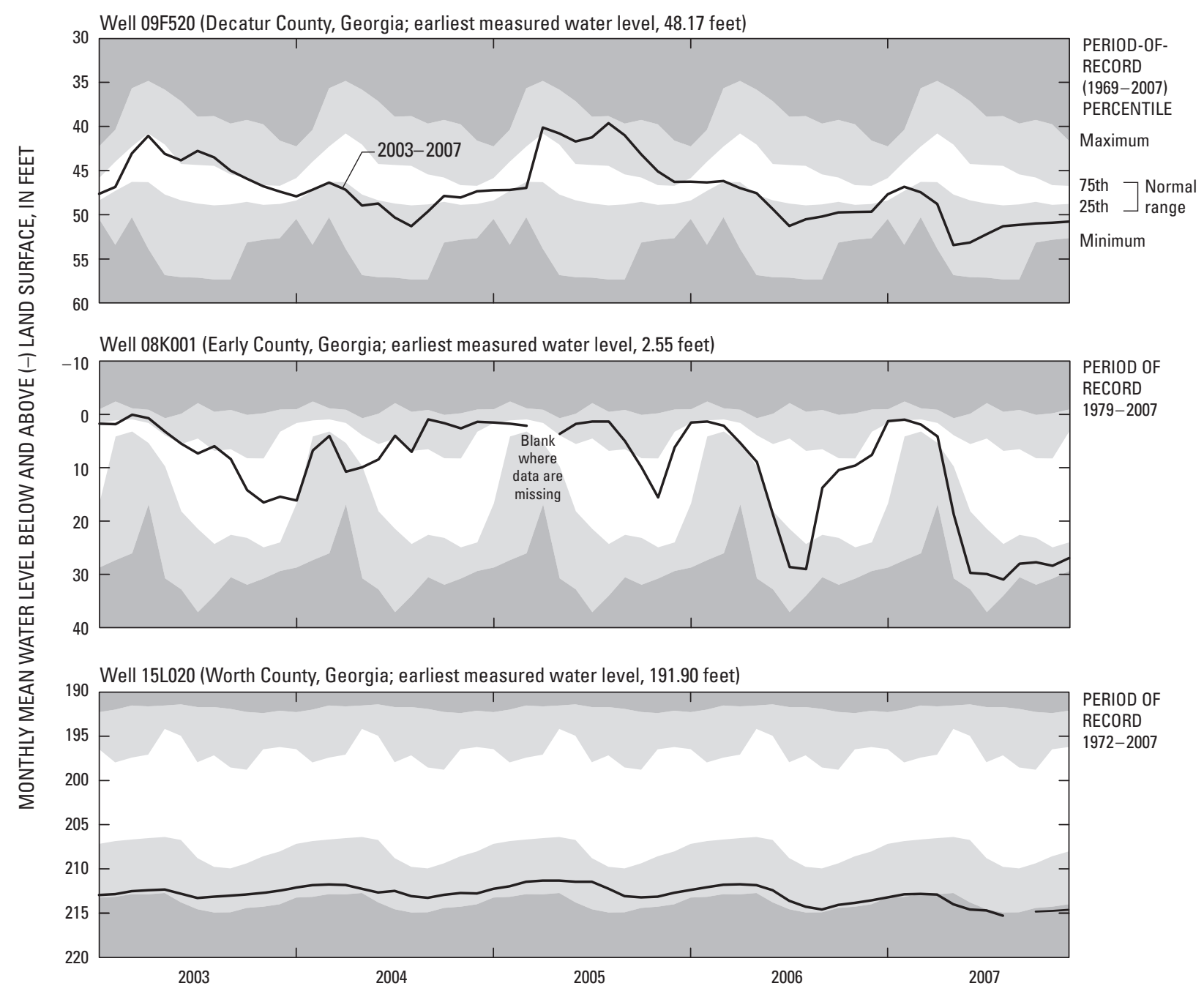




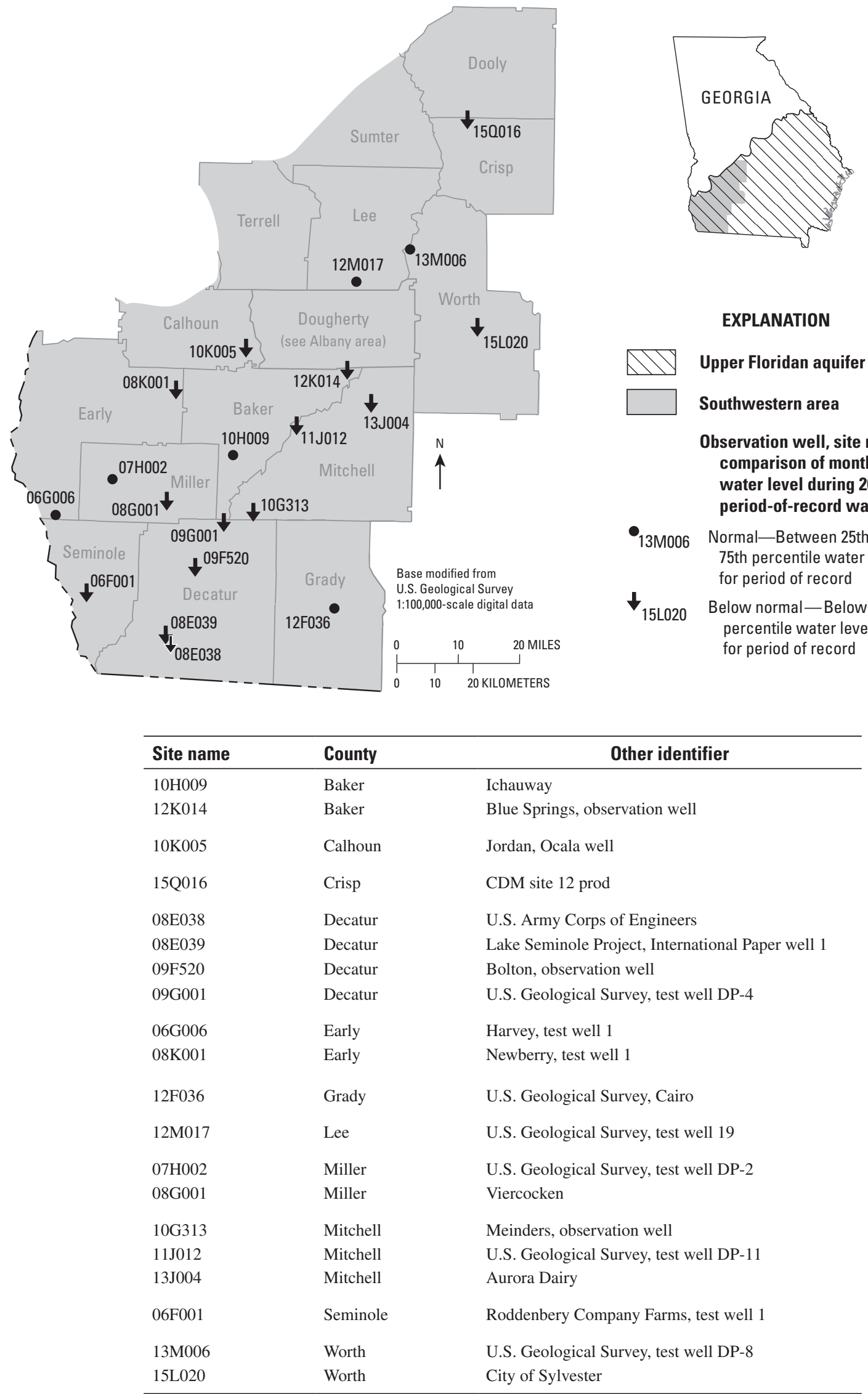




\section{Ground-Water Levels}

\section{Upper Floridan Aquifer}

\section{City of Albany-Dougherty County Area}

Water levels in 12 wells were used to define ground-water conditions in the Upper Floridan aquifer near Albany, Georgia, during 2007 (Dougherty County map, facing page). Water levels were below the normal range in nine of the wells and in the normal range in the three remaining wells.

Hydrographs for three wells in the Upper Floridan aquifer in the Albany area, Dougherty County (below), illustrate monthly mean water levels during 2003-2007 and period-of-record water-level statistics. The water level in well $11 \mathrm{~K} 003$ was below normal in early 2003 but rose to the normal to abovenormal range through mid-2006. The water level declined and remained below normal through 2007 except for a short period in early 2007 when it was in the normal range. Water levels in wells 12L029 and 13L049 generally were normal or above normal from 2003 to early 2007 but then began to decline to the normal and below-normal range, respectively.
In addition to continuous water-level monitoring, synoptic water-level measurements are made periodically in wells southwest of Albany. Water-level measurements were collected from 64 wells during October 2006 and 58 wells during October 2007. The measurements were used to construct maps showing the potentiometric surface of the Upper Floridan aquifer for these two time periods. The potentiometric-contour maps (facing page) show that water generally flows from northwest to southeast toward the Flint River. In the southeastern part of the mapped area, flow was away from the river toward the west. Water levels were higher during 2006 than during 2007.

\section{Reference}

Gordon, D.W., 2008, Ground-water conditions and studies in the Albany area of Dougherty County, Georgia, 2007: U.S. Geological Survey Open-File Report 2008-1328, 49 p.; Web-only publication available at http://pubs. usgs.gov/of/2008/1328/.

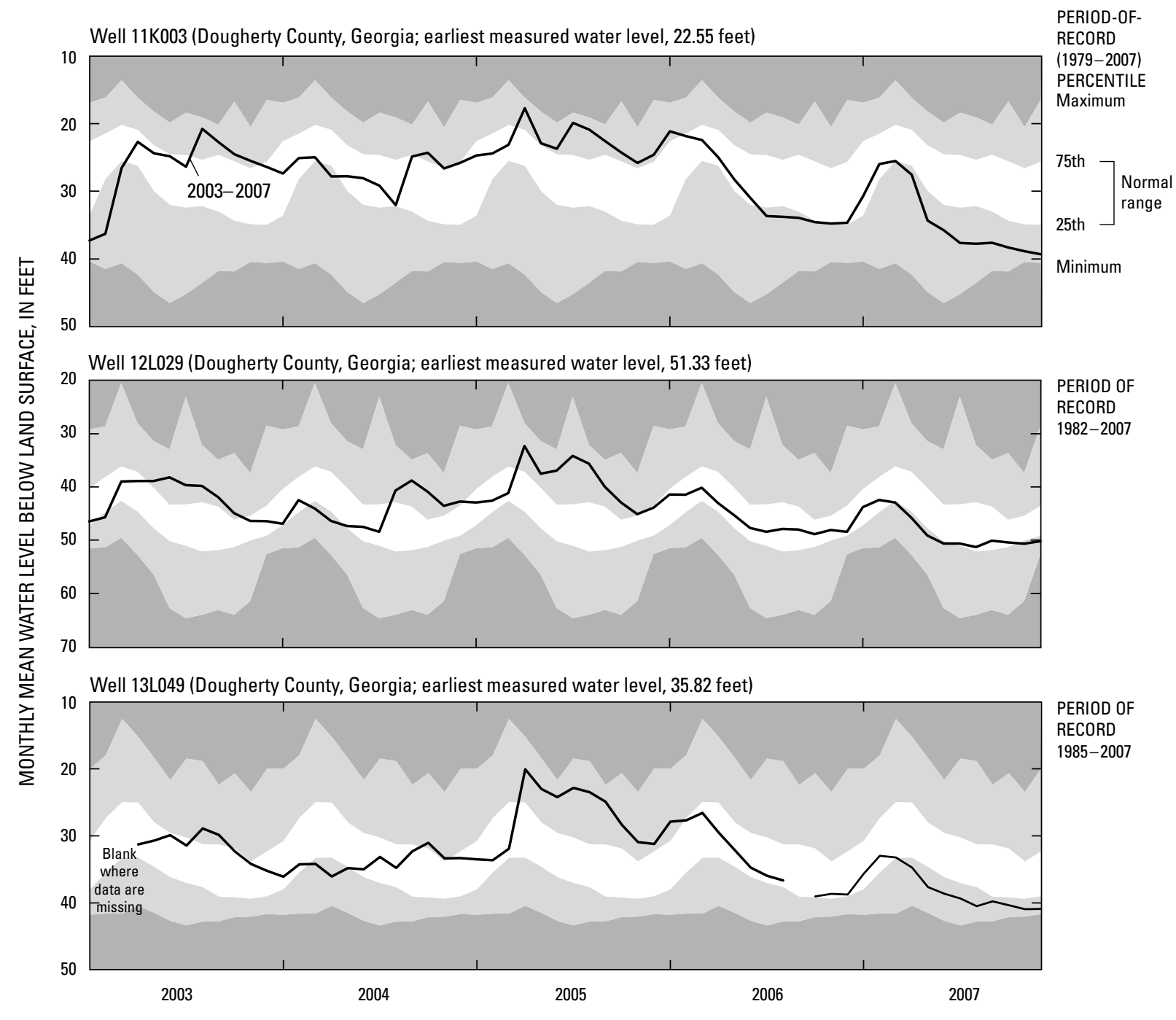




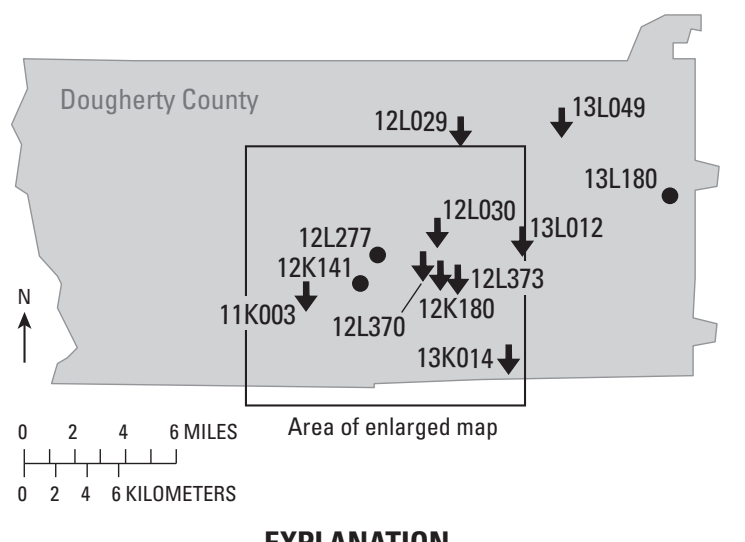

Upper Floridan aquifer

City of Albany-Dougherty County area

Observation well, site name, and comparison of monthly mean water level during 2007 to period-of-record water level

12K141 - Normal-Between 25th and 75th percentile water levels for period of record $11 \mathrm{~K} 003^{\downarrow}$ Below normal-Below 25th percentile water level for period of record

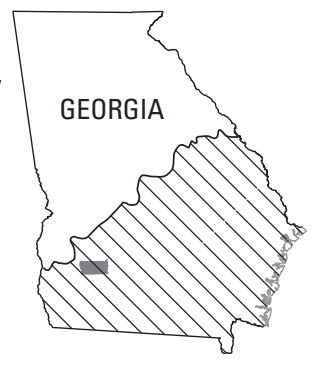

\begin{tabular}{ll}
\hline Site name & \multicolumn{1}{c}{ Other identifier } \\
\hline 11 K003 & Nilo test well, north \\
12 K141 & Albany Water, Gas, and Light \\
& Commission, A750 \\
12K180 & Albany Water, Gas, and Light Commission, \\
& Georgia Environmental Protection \\
& Division, MW-2 \\
12L029 & U.S. Geological Survey, test well 13 \\
12L030 & U.S. Geological Survey, test well 16 \\
12L277 & Albany Water, Gas, and Light \\
& Commission, test well 1 \\
12L370 & Albany Water, Gas, and Light Commission, \\
& MW-100D \\
12L373 & Albany Water, Gas, and Light Commission, \\
& Georgia Environmental Protection \\
& Division, MW-1 \\
13K014 & U.S. Geological Survey, test well 15 \\
13L012 & U.S. Geological Survey, test well 3 \\
13L049 & Miller, observation well \\
13L180 & Marine Corps Logistic Base, core hole 3 \\
\hline
\end{tabular}
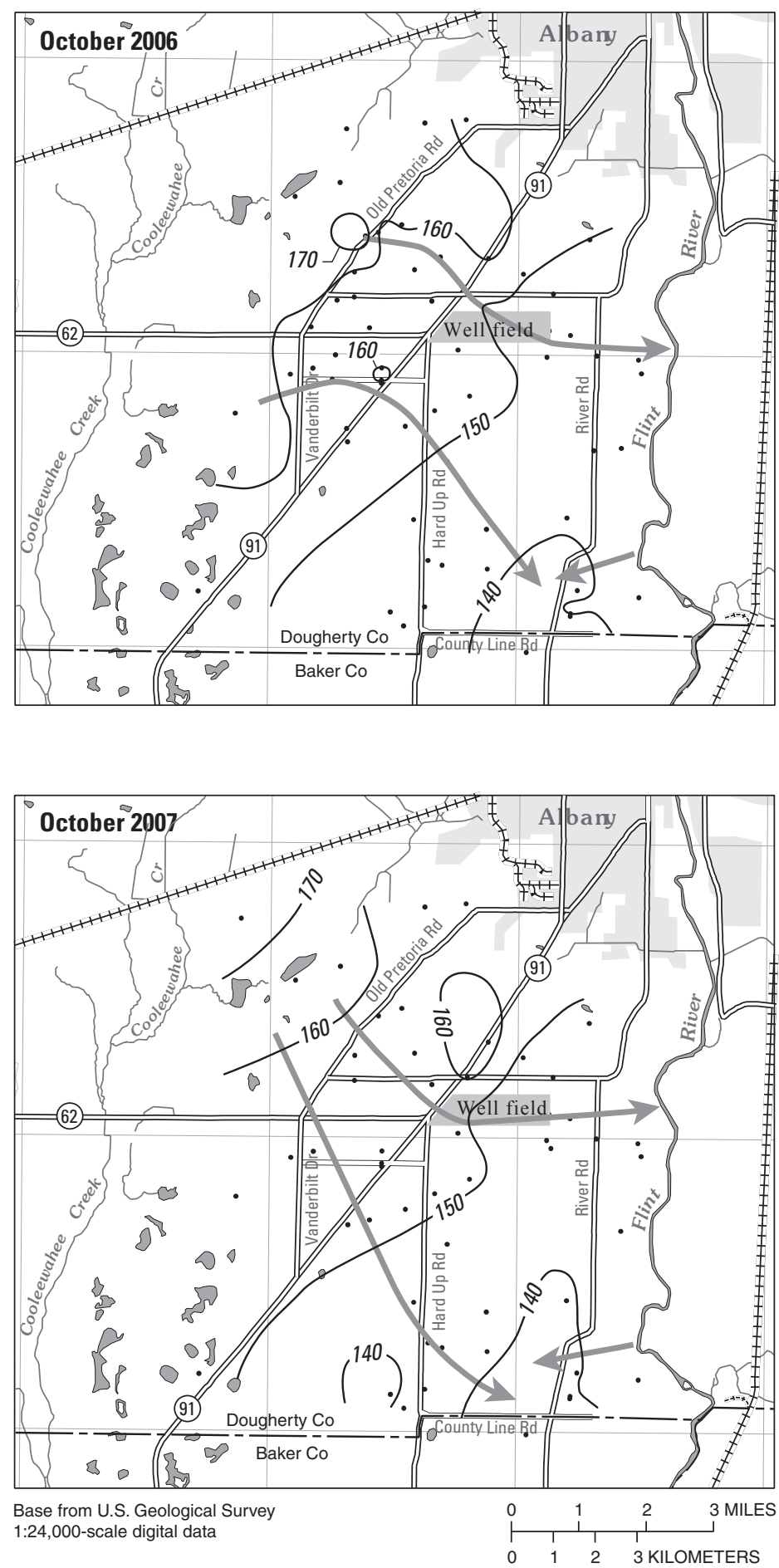

\section{EXPLANATION}

- 160 - Potentiometric contour-Shows altitude at which water level would have stood in tightly cased wells. Hachures indicate depression. Contour interval 10 feet. Datum is North American Vertical Datum of 1988 (October 2007 map modified from Gordon, 2008)

$\longrightarrow$ Direction of ground-water flow

- Well data point 


\section{Ground-Water Levels}

\section{Upper Floridan Aquifer}

\section{South-Central Area}

Water levels in three wells were used to define ground-water conditions in the Upper Floridan aquifer in south-central Georgia during 2007 (map and table, facing page). In this area, water in the Upper Floridan aquifer generally is confined but locally is unconfined in areas of karst features in Lowndes County. Water levels in all three wells were below normal during 2007 because of the effects of a drought that began in 2006, and two of the wells had record-low water levels.

Hydrographs for three wells in the Upper Floridan aquifer in south-central Georgia (below) illustrate monthly mean water levels during 2003-2007 and period-of-record water-level statistics. The water level in well 19E009 in Lowndes County was in the normal to above-normal range from 2003 to early 2006 when the water level declined to below normal through the end of 2007. In well 19E009, the water level has a quicker, more pronounced response to climatic effects because of proximity to karst. In the other two wells, climatic effects are less pronounced, and water levels primarily are influenced by pumping. Hydrographs for wells $18 \mathrm{H} 016$ in Cook County and 18K049 in Tift County both show a long-term downward trend, with water levels in the below-normal range. The water level in well 18H016 was mostly below normal during 2003-2007. Record-low water levels were recorded in well $18 \mathrm{H} 016$ during 2007. The water level in well $18 \mathrm{~K} 049$ was below normal from 2003 to early 2005 when the water level briefly rose to normal and then declined to below normal through the end of 2007 when record-low water levels were recorded.

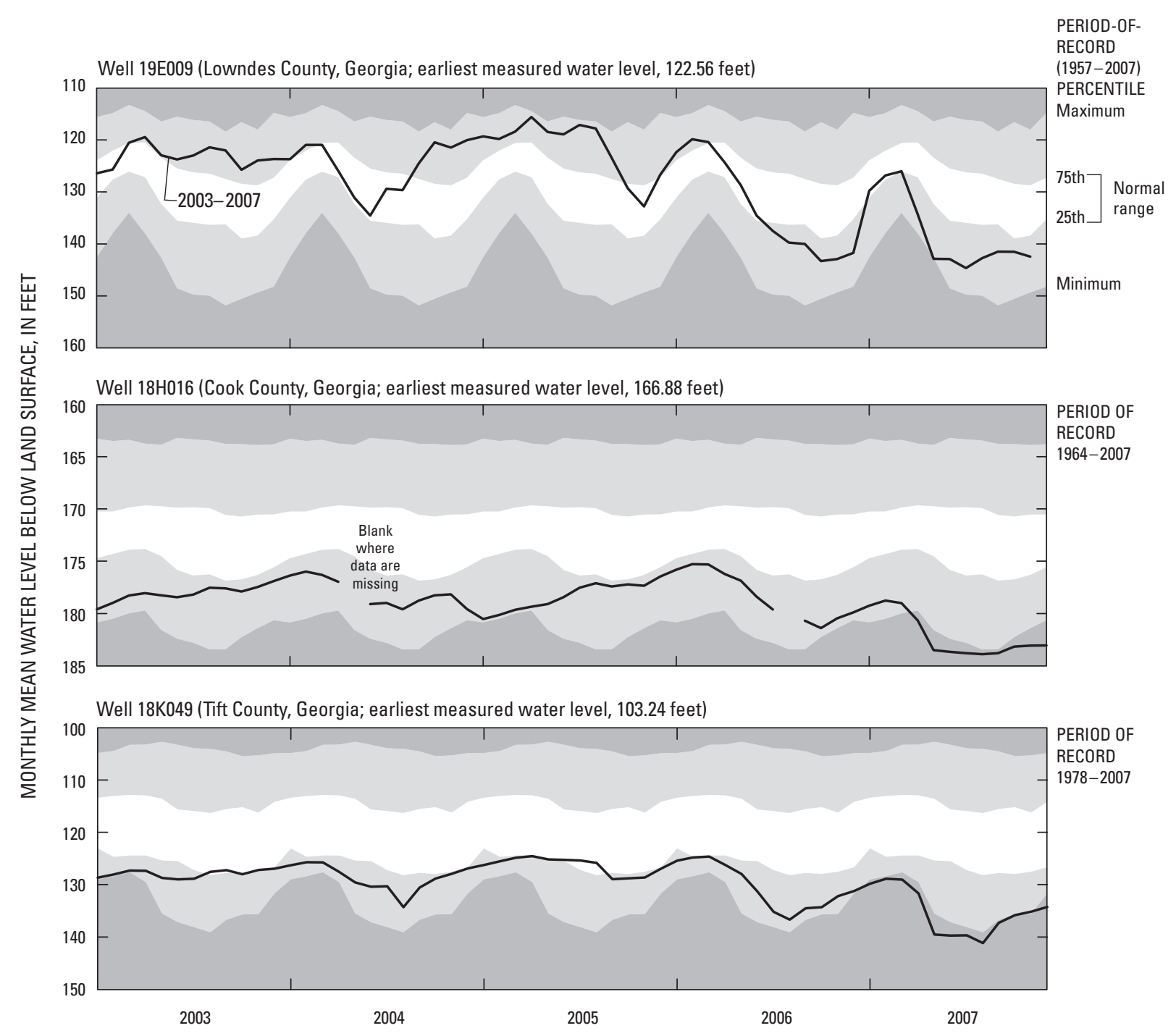




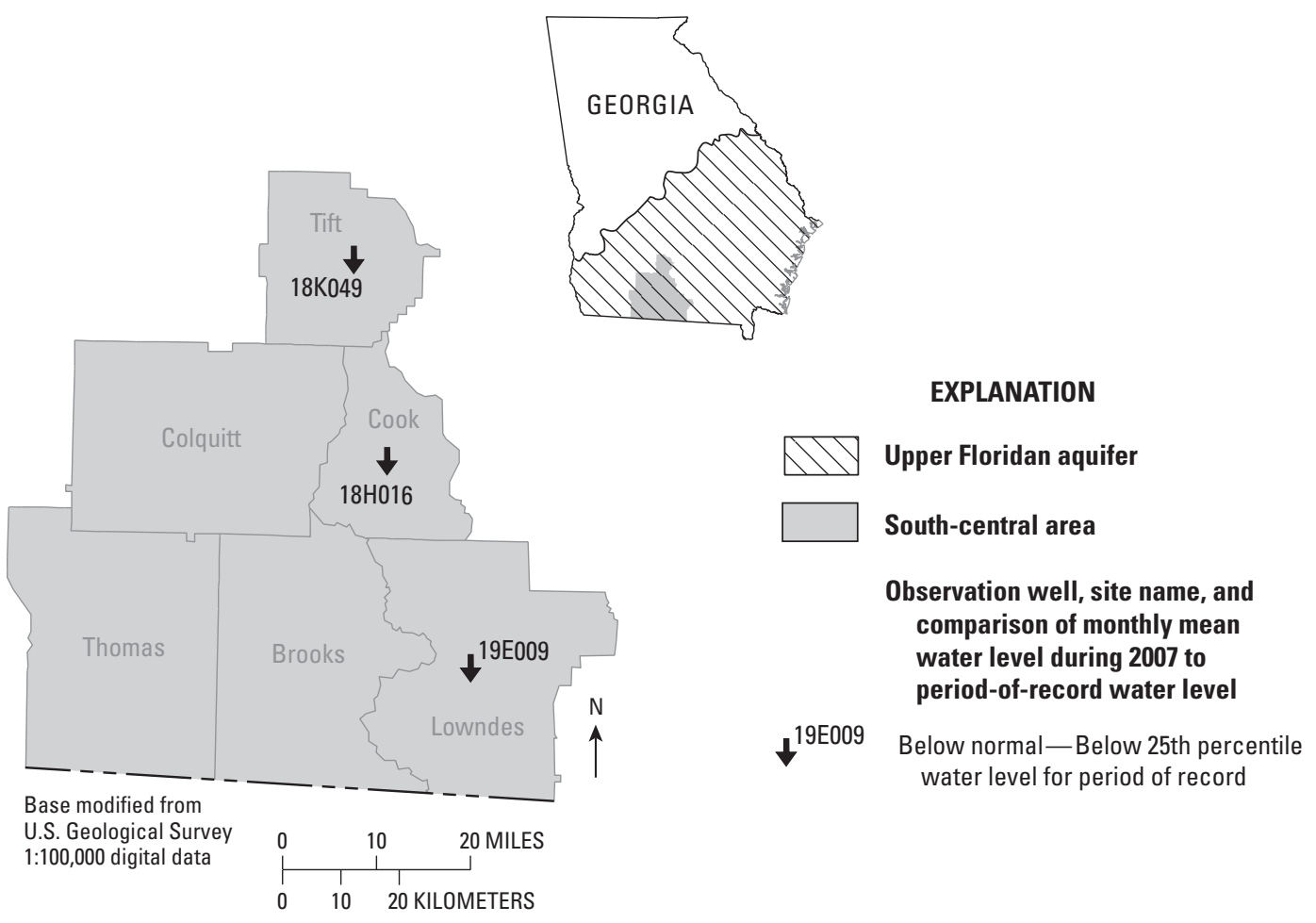

\begin{tabular}{lll}
\hline Site name & County & \multicolumn{1}{c}{ Other identifier } \\
\hline 18 H016 & Cook & U.S. Geological Survey, Adel test well \\
$19 \mathrm{E} 009$ & Lowndes & City of Valdosta \\
18 K049 & Tift & U.S. Geological Survey, test well 1 \\
\hline
\end{tabular}




\section{Ground-Water Levels}

\section{Upper Floridan Aquifer}

\section{East-Central Area}

Water levels in two wells were used to define ground-water conditions in the Upper Floridan aquifer in east-central Georgia during 2007 (map and table, facing page). In this area, water in the Upper Floridan aquifer is confined to the southeast and is semiconfined to the northwest. The water levels in wells 21T001 and 25Q001were below normal during 2007 because of the effects of a drought that began in 2006, and record-low water levels were recorded in both wells.

Hydrographs for both wells in the Upper Floridan aquifer in east-central Georgia (below) illustrate monthly mean water levels during 2003-2007 and period-of-record water-level statistics. Well 21T001 in Laurens County is in the northwestern part of the area where the aquifer is semiconfined.
The water level in this well was above normal during much of 2003 and early 2004 but declined to below normal through mid-2004. The water level remained at or above normal through late 2005 when it declined to below normal and remained below normal through 2007 when a record-low water level was recorded. Water levels in this area are influenced by climatic effects and agricultural pumping. Well 25Q001 in Montgomery County is located in an area where the aquifer is deeply buried and confined and is influenced by local and regional pumping. During 2003-2007, the water level in the well was below normal, and record-low water levels were recorded in 2007. The water level in this well has shown a downward trend for most of the period of record; however, during 2003 through 2005 , the water level in this well rose, a trend that began in 2002, but then began to decline in early 2006 through 2007. Water levels remained below normal as a result of long-term declines from pumping.

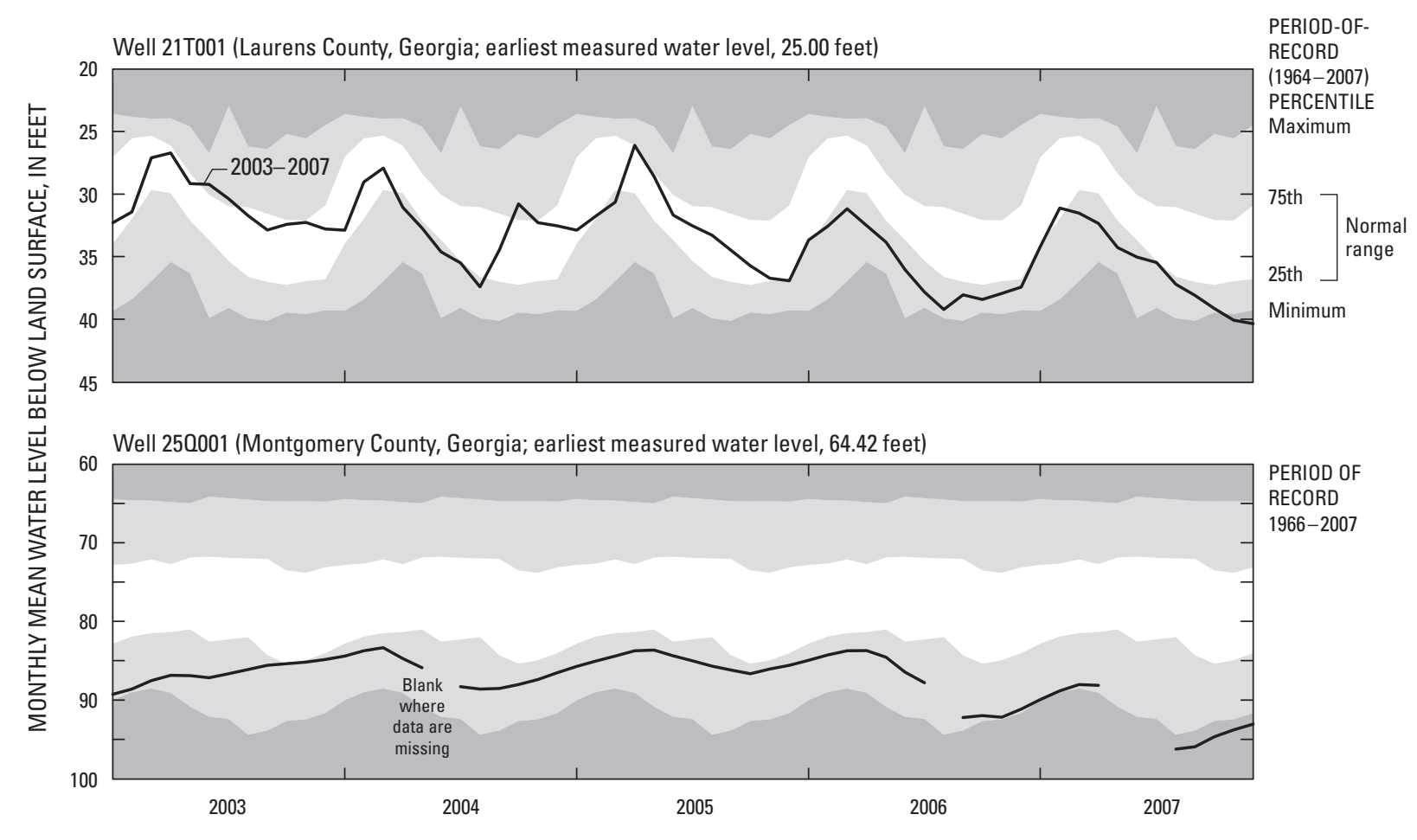



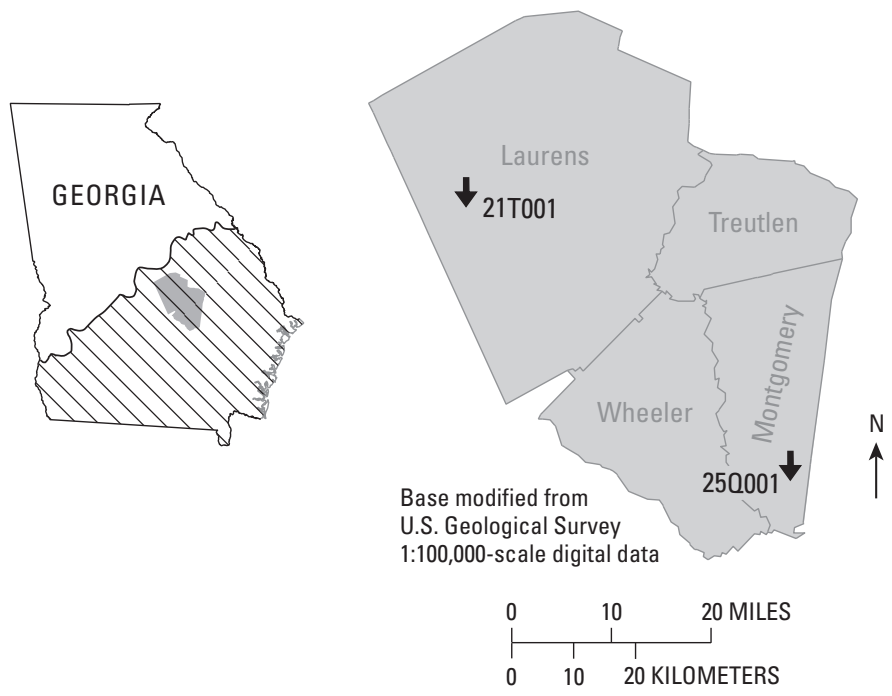

EXPLANATION

NIVper Floridan aquifer

$\square$ East-central area

Observation well, site name, and comparison of monthly mean water level during 2007 to period-of-record water level

$250001 \downarrow$ Below normal-Below 25th percentile water level for period of record

\begin{tabular}{lll}
\hline Site name & County & Other identifier \\
\hline $21 \mathrm{~T} 001$ & Laurens & Hogan, observation well \\
$25 \mathrm{Q} 001$ & Montgomery & Montgomery County Board of Education \\
\hline
\end{tabular}




\section{Ground-Water Levels}

\section{Upper Floridan Aquifer}

\section{Northern Coastal Area}

Water levels in two wells were used to define ground-water conditions in the Upper Floridan aquifer in the northern coastal area during 2007 (map and table, facing page). Water in the Upper Floridan aquifer is unconfined in this area, especially in updip areas to the north, and confined elsewhere. Water levels in the two wells were below normal during 2007 because of the effects of a drought that began in 2006, and record-low water levels were recorded in one well. Both wells are located in areas where agricultural water use is prevalent.
Hydrographs for both wells in the Upper Floridan aquifer in northern coastal Georgia (below) illustrate monthly mean water levels during 2003-2007 and period-of-record waterlevel statistics. The water-level trend in well 26R001 in Toombs County has been downward for most of the period of record continuing through 2007, when water levels reached record daily lows. During 2003-2007, the water level remained below normal and began a steeper decline in mid-2006. The water level in well 31U008 in Bulloch County shows a similar trend. During 2003 to mid-2006, the water level rose and ranged from normal to below normal; it began to decline in early 2006 and remained below normal through the end of 2007.

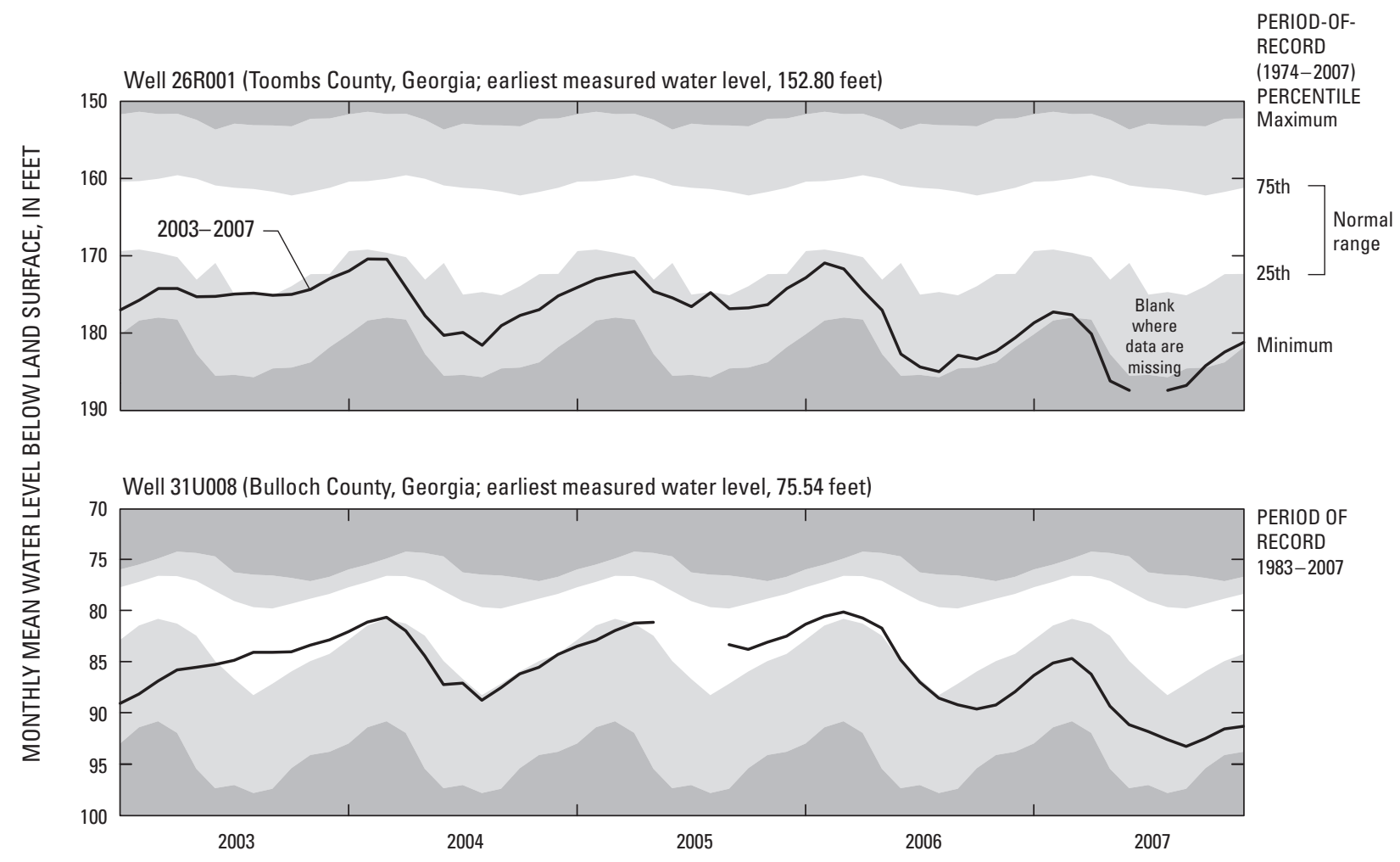




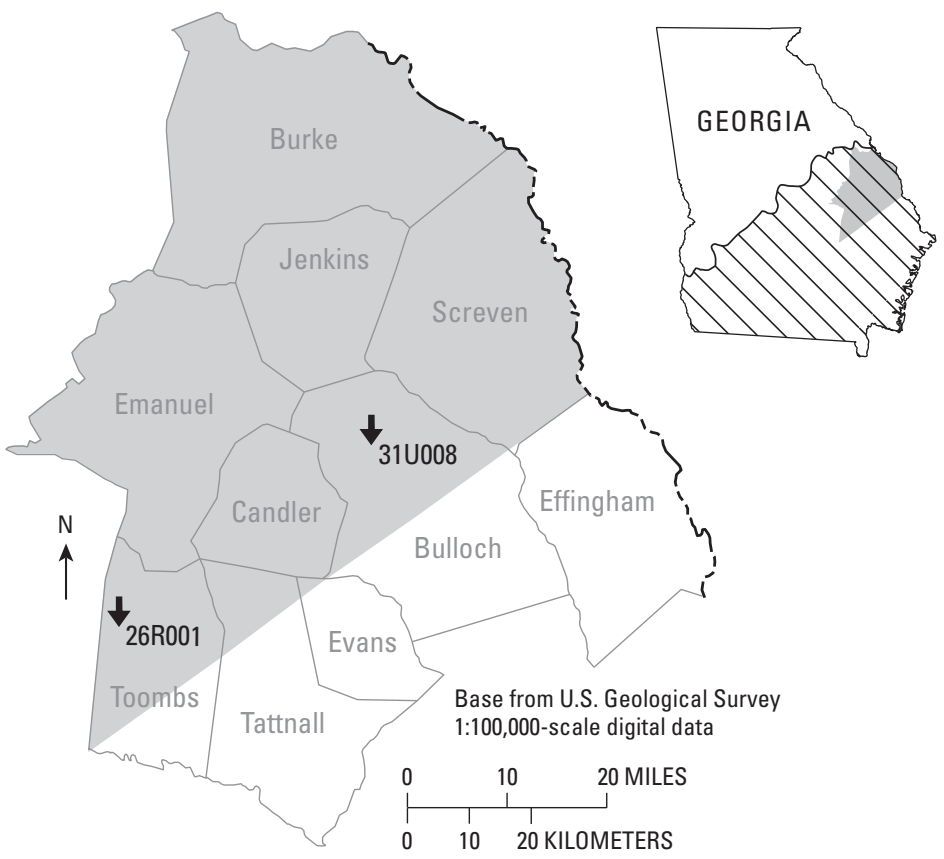

EXPLANATION

Mpper Floridan aquifer

Northern coastal area

Observation well, site name, and comparison of monthly mean water level during 2007 to period-of-record water level

$\downarrow$ percentile water level for period of record

\begin{tabular}{lll}
\hline Site name & County & \multicolumn{1}{c}{ Other identifier } \\
\hline $26 \mathrm{R} 001$ & Toombs & City of Vidalia, well 2 \\
$31 \mathrm{U} 008$ & Bulloch & Georgia Geologic Survey, Hopeulikit, test well 1 \\
\hline
\end{tabular}




\section{Ground-Water Levels}

\section{Upper Floridan Aquifer}

\section{Central Coastal Area}

Water levels in 16 wells were used to define ground-water conditions in the Upper Floridan aquifer in the central coastal area of Georgia (excluding Glynn County) during 2007 (map and table, facing page). In this area, water in the Upper Floridan aquifer is confined and influenced primarily by pumping. Water levels in eight wells were within the normal range, above normal in one well, and below normal in seven wells. A record-high water level was recorded in one well.

Hydrographs for three wells in the Upper Floridan aquifer in the central coastal area of Georgia (below) illustrate monthly mean water levels during 2003-2007 and period-of-record water-level statistics. The water level in well 35T003 in Effingham County during 2003-2007 was in the normal to above-normal range for the period, and a record-high water level was recorded in early 2006. The water level has been declining since then, however, and dropped below normal for a few months in mid-2007. Well 36Q008 near Savannah in Chatham County was normal or above normal during 2003-2007 because of continued decreases in water use as a result of conservation (J.L. Fanning, U.S. Geological Survey, oral commun., 2008). The hydrograph for well 33M004 in Long County shows a slight water-level rise during 2003 to mid-2006 when the water level was mostly in the normal range- a trend that began in 2002 when the previous drought ended. However, the water level started to decline in mid-2006 to below normal and reached a record-low water level by the end of 2007.
Well 35T003 (Effingham County, Georgia; earliest measured water level, 30.21 feet)

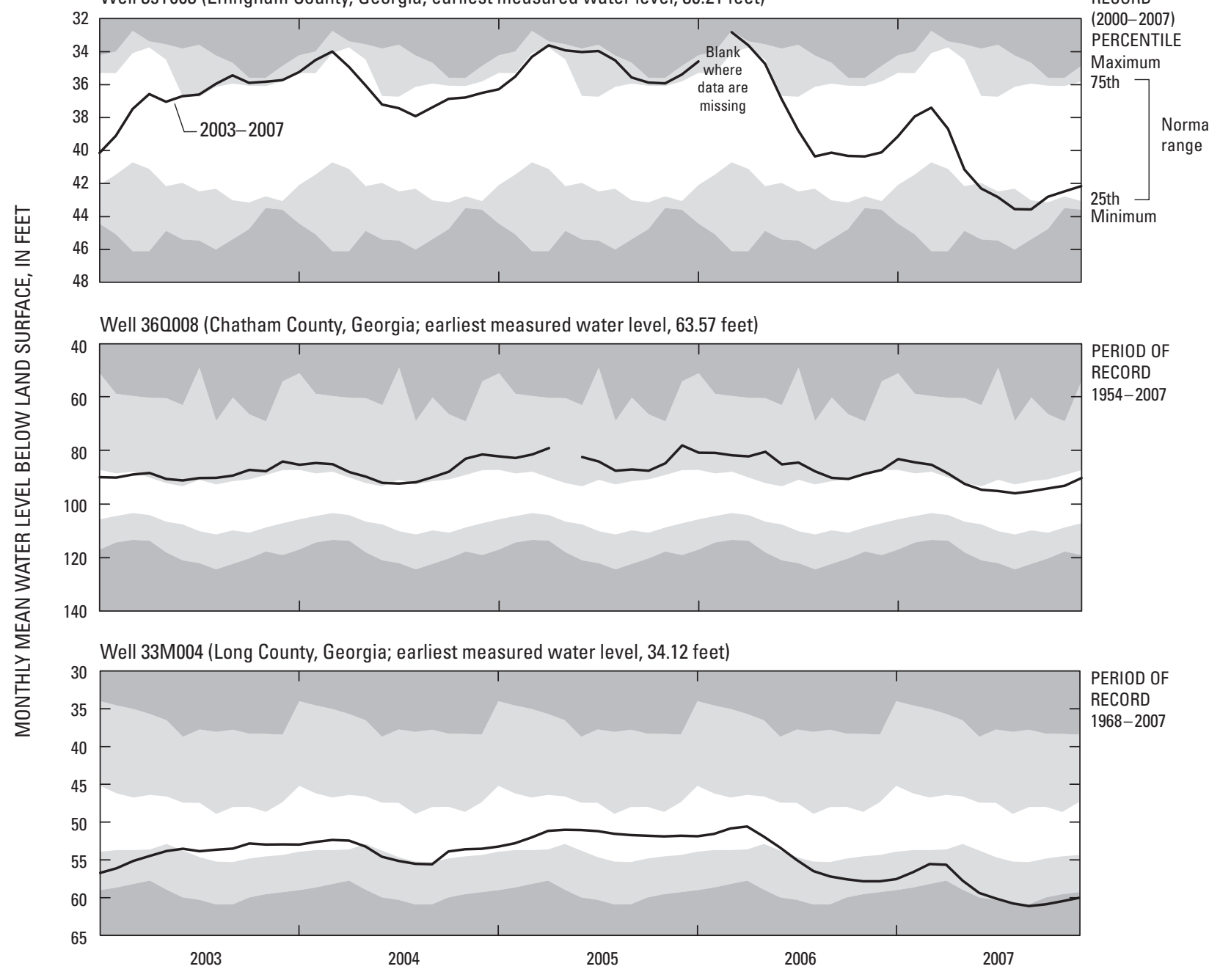

PERIOD-OFRECORD Norma range 

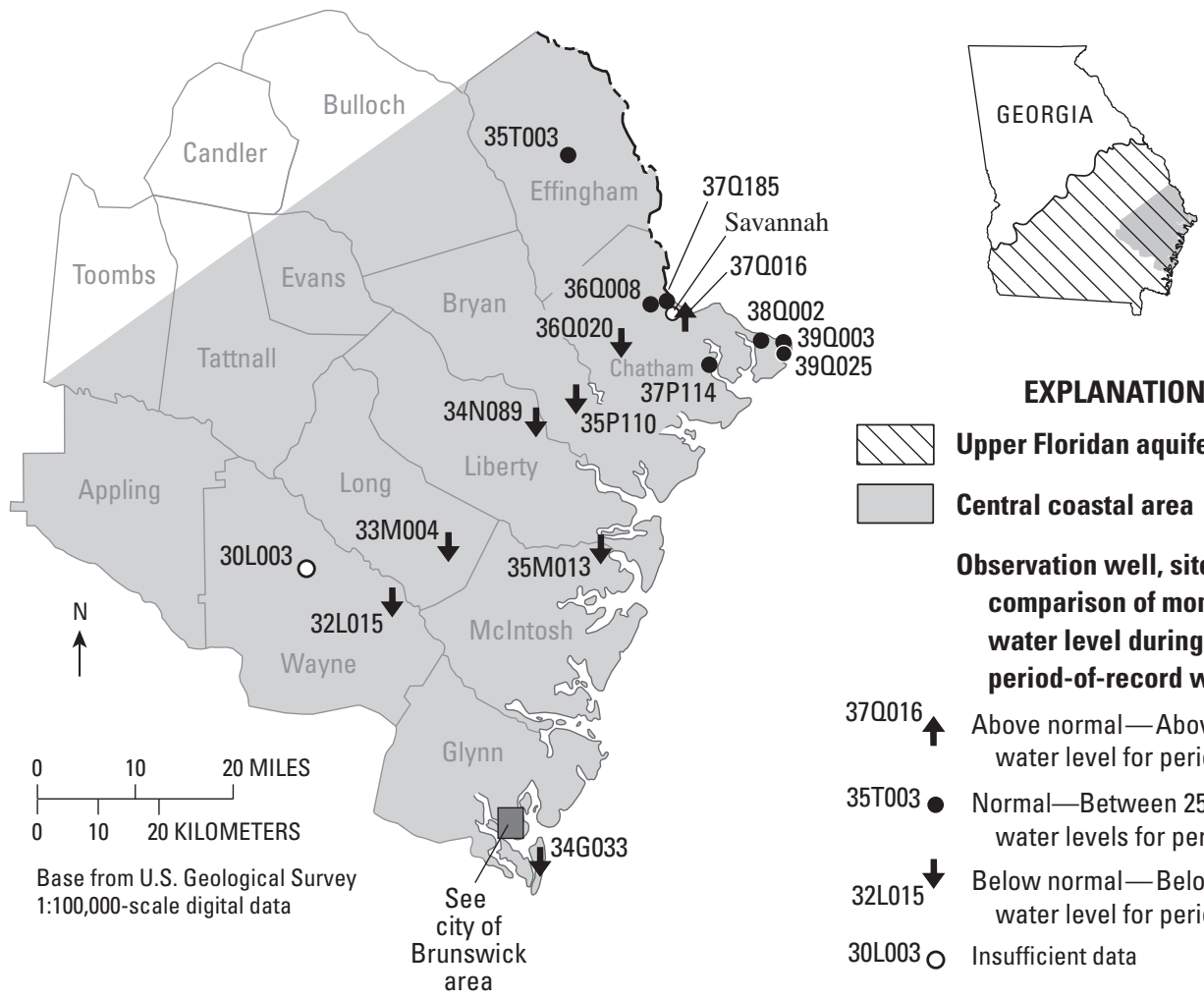

EXPLANATION

Upper Floridan aquifer

Central coastal area

Observation well, site name, and comparison of monthly mean water level during 2007 to period-of-record water level

${ }^{370016}$ A Above normal-Above 75th percentile water level for period of record

$35 \mathrm{T003}$ Normal-Between 25th and 75th percentile water levels for period of record

32L015 $\downarrow$ Below normal-Below 25th percentile water level for period of record

30 L003 O Insufficient data

\begin{tabular}{|c|c|c|}
\hline Site name & County & Other identifier \\
\hline $35 \mathrm{P} 110$ & Bryan & Richmond Hill, test well \\
\hline 36Q008 & Chatham & Lance-Atlantic Company \\
\hline 36Q020 & Chatham & Morrison, observation well \\
\hline 37P114 & Chatham & Georgia Geologic Survey, Skidaway Institute, test well 2 \\
\hline $37 \mathrm{Q} 016$ & Chatham & East Coast Terminal well \\
\hline 37Q185 & Chatham & U.S. Geological Survey, Hutchinson Island, test well 1 \\
\hline 38Q002 & Chatham & U.S. National Park Service, test well 6 \\
\hline 39Q003 & Chatham & U.S. Geological Survey, test well 7 \\
\hline 39Q025 & Chatham & Georgia Geologic Survey, Tybee Island, test well 2 \\
\hline $35 \mathrm{~T} 003$ & Effingham & City of Springfield \\
\hline 34G033 & Glynn & Jekyll Island Authority Number 9 \\
\hline 34N089 & Liberty & U.S. Geological Survey, test well 1 \\
\hline 33M004 & Long & U.S. Geological Survey, test well 3 \\
\hline $35 \mathrm{M} 013$ & McIntosh & U.S. Fish and Wildlife Service, Harris Neck 1 \\
\hline${ }^{1} 30 \mathrm{~L} 003$ & Wayne & City of Jesup Housing Authority \\
\hline 32L015 & Wayne & Georgia Geologic Survey, Gardi, test well 1 \\
\hline
\end{tabular}

'Well is completed in the upper and lower Brunswick aquifers and the Upper Floridan aquifer. 


\section{Ground-Water Levels}

\section{Upper Floridan Aquifer}

\section{City of Brunswick Area}

Water levels in five wells were used to define ground-water conditions in the Upper Floridan aquifer near the city of Brunswick in the central coastal area of Georgia during 2006-2007 (map and insets, facing page). In this area, water in the Upper Floridan aquifer is confined, and ground-water flow paths are influenced primarily by pumping for industrial and public supply. Water levels in four of the five wells were near the normal range during 2007.

Hydrographs for three wells (33H133, 34H334, and 34H371, below) in the Upper Floridan aquifer near the city of Brunswick, Glynn County, show water-level trends. The water level in well 33H133 remained in the above-normal range during 2006-2007, whereas water levels in wells 33H334 and 34H371 were above-normal through mid-2006 and then decreased to normal levels by the end of 2007 . These waterlevel declines are a departure from near record-high levels recorded during 2004 (Leeth and others, 2007).

In addition to continuous water-level monitoring, synoptic water-level measurements are made periodically in wells in the Brunswick area. Water-level measurements from 20 wells were collected during July 2006 and from 22 wells during July and August 2007 and subsequently were used to construct potentiometric-surface maps of the Upper Floridan aquifer. The maps on the facing page show that ground water generally flows from the south-southeast, where water-level altitudes are greater than 10 feet, toward industrial pumping centers in northern Brunswick, where water-level altitude is less than 0 feet. Water-level altitudes decreased from 1.5 to 8.2 feet during 2006-2007, idicating an expansion of the zone of influence from industrial production wells in the northwest. Despite these water-level declines, the overall direction of ground-water flow remained the same.

\section{References}

Cherry, G.S., and Clarke, J.S., 2008, Ground-water conditions and studies in the Brunswick-Glynn County area, Georgia, 2007: U.S. Geological Survey Open-File Report 2008-1297, 42 p.; Web-only publication available at http://pubs.usgs.gov/ of/2008/1297/.

Leeth, D.C., Peck, M.F., and Painter, J.A., 2007, Ground-water conditions and studies in Georgia, 2004-05: U.S. Geological Survey Scientific Investigations Report 2007-5017, 299 p.; Web-only publication available at http://pubs.usgs.gov/ sir/2007/5017/.

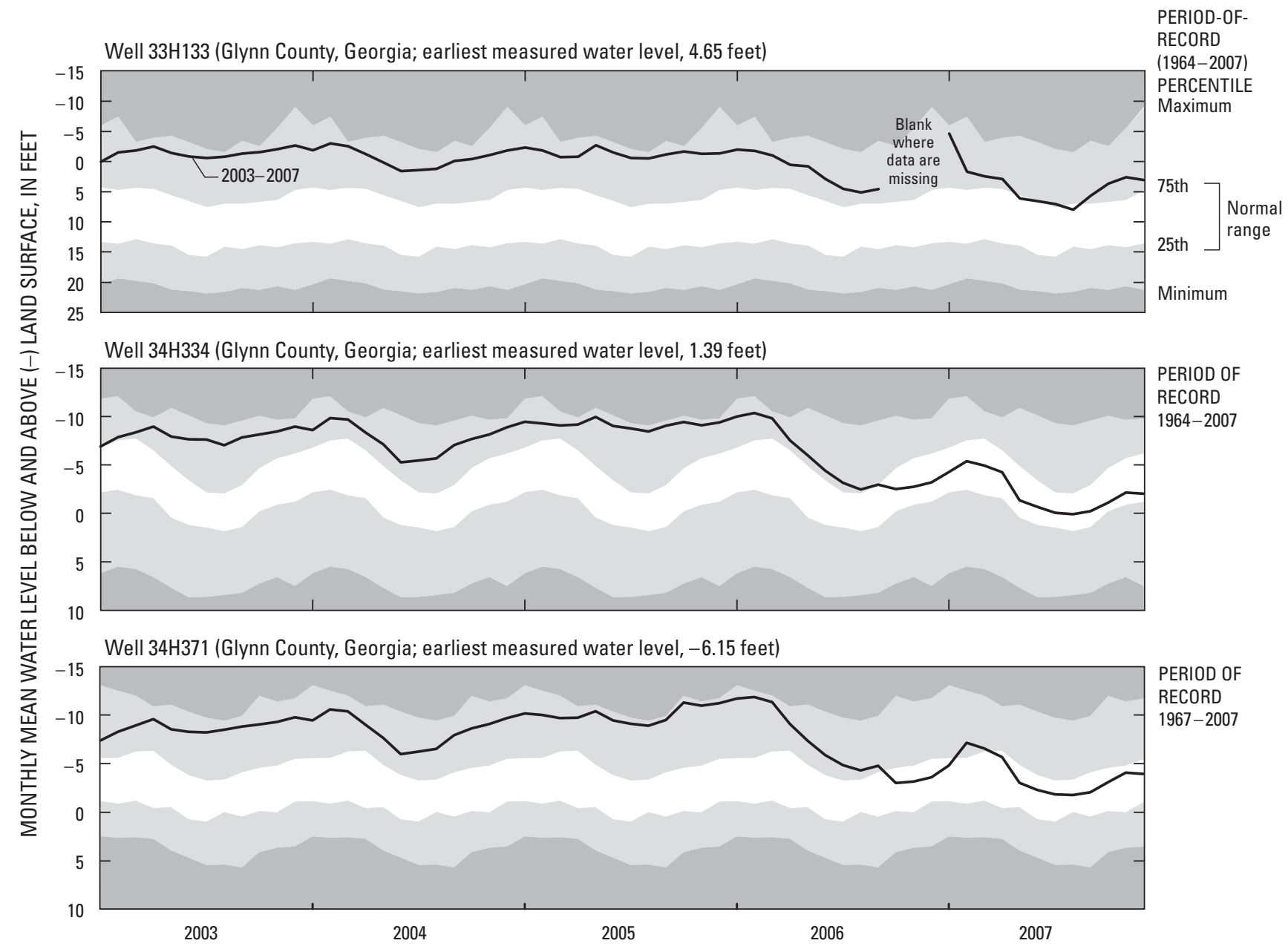




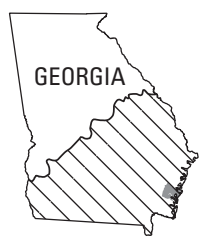

EXPLANATION Upper Floridan aquifer

City of Brunswick area

Observation well, site name, and comparison of mean annual water level during 2007 to period-of-record water level

433H127 Above normal-Above 75th percentile water level for period of record

33H207 Normal-Between 25th and 75th percentile water level for period of record

O $33 \mathrm{H} 325$ Insufficient data

\begin{tabular}{|c|c|c|}
\hline Site name & County & Other identifier \\
\hline $33 \mathrm{H} 127$ & Glynn & U.S. Geological Survey, test well 3 \\
\hline $33 \mathrm{H} 133$ & Glynn & U.S. Geological Survey, test well 6 \\
\hline $33 \mathrm{H} 207$ & Glynn & Georgia-Pacific, south test well 2 \\
\hline $33 \mathrm{H} 324$ & Glynn & $\begin{array}{l}\text { Georgia-Pacific, Lower water-bearing zone } \\
\text { Coastal Sound Science Initiative }\end{array}$ \\
\hline $33 \mathrm{H} 325$ & Glynn & $\begin{array}{l}\text { Georgia-Pacific, Upper water-bearing zone } \\
\text { Coastal Sound Science Initiative }\end{array}$ \\
\hline $34 \mathrm{H} 334$ & Glynn & U.S. Geological Survey, test well 4 \\
\hline $34 \mathrm{H} 371$ & Glynn & U.S. Geological Survey, test well 11 \\
\hline
\end{tabular}

July 2006

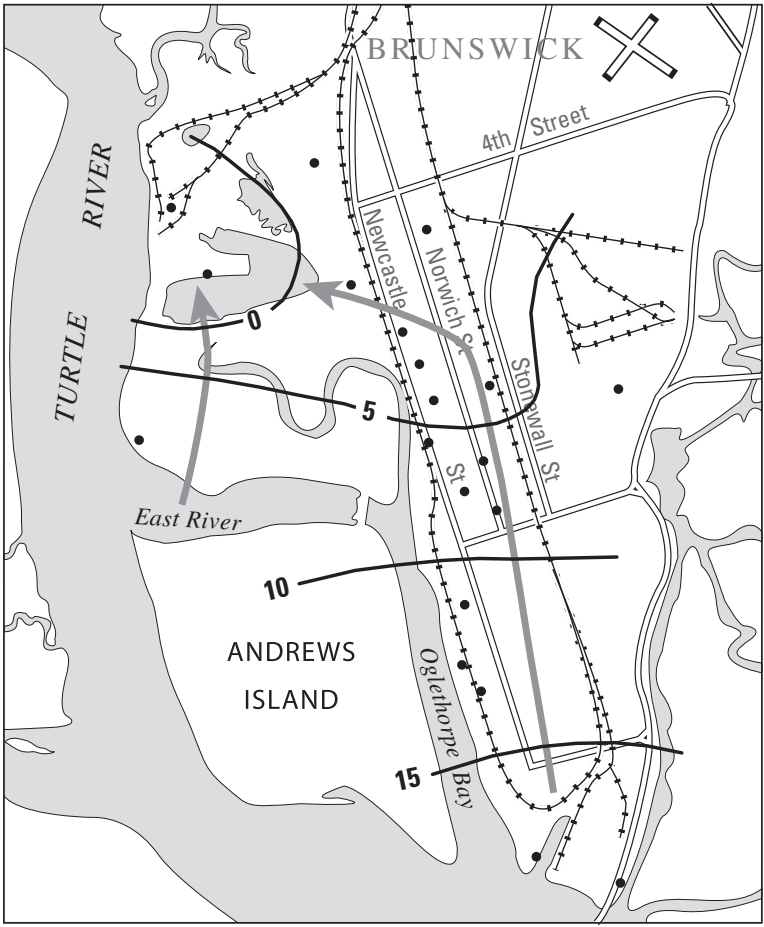

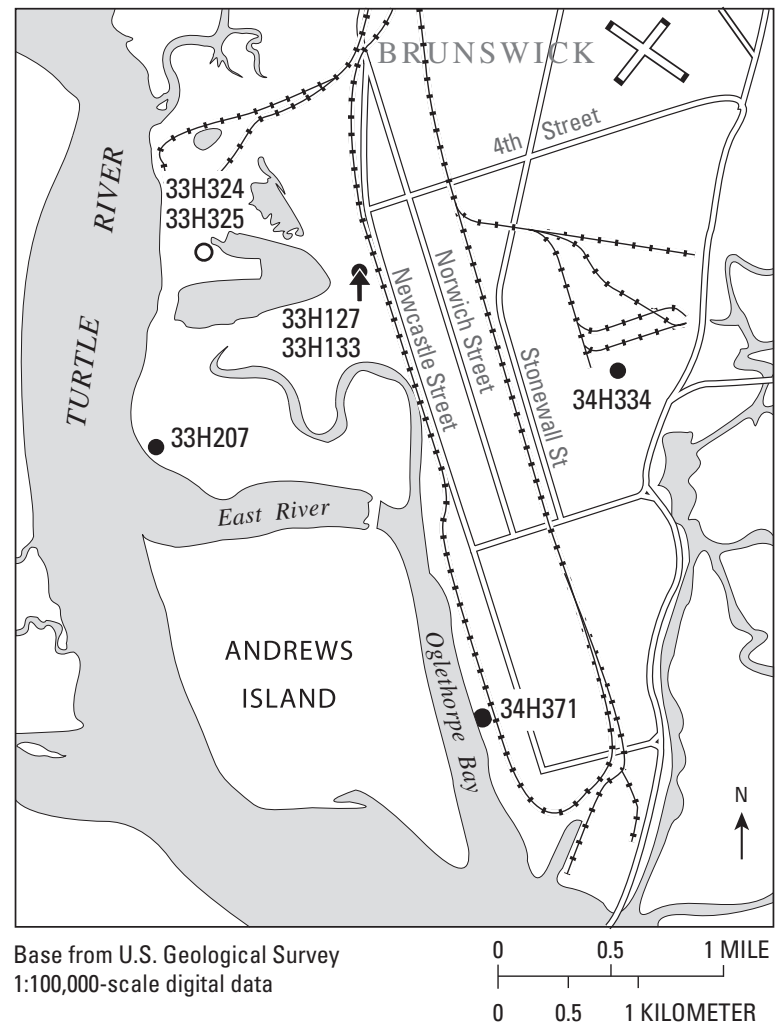

July-August 2007

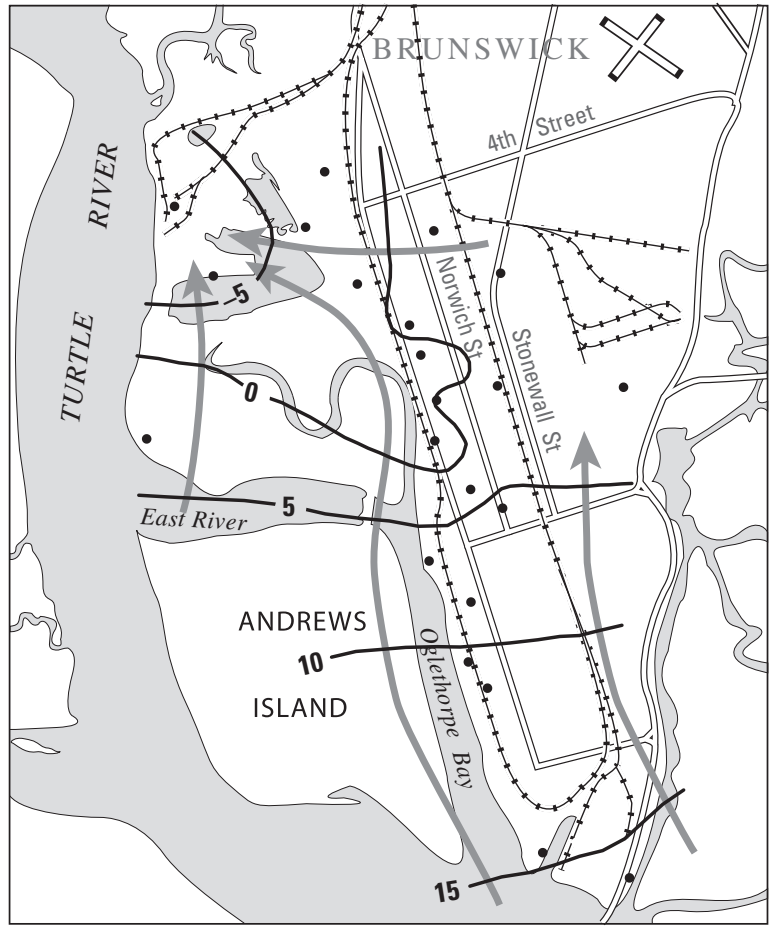

\section{EXPLANATION}

- 15 - Potentiometric contour - Shows altitude at which water level would have stood in tightly cased wells in the Upper Floridan aquifer. Contour interval 5 feet.

Datum is North American Vertical Datum of 1988 (modified from Cherry and Clarke, 2008)

\section{General direction of ground-water flow}




\section{Ground-Water Levels}

\section{Upper Floridan Aquifer}

\section{Southern Coastal Area}

Water levels in five wells were used to define ground-water conditions in the Upper Floridan aquifer in the southern coastal area of Georgia during 2007 (map and table, facing page). In this area, water in the Upper Floridan aquifer is confined and influenced mostly by pumping to the east in the Fernandina Beach area, Florida, and by climatic effects and pumping to the west. Water levels in three of the wells monitored were in the normal range and in the below-normal range in the other two wells during 2007.

Hydrographs for three wells in the Upper Floridan aquifer in the southern coastal area (below) illustrate monthly mean water levels during 2003-2007 and period-of-record water-level statistics. The water-level in all three wells rose during 2003 to early 2006 and then declined through the end of 2007 when recordlow water levels were recorded in two of the wells. The water level in well 33E027 in Camden County did not reach a recordlow level and remained higher than water levels in the other wells because of the closure of the nearby Durango Corporation Paper Mill in St. Marys in 2002, which decreased water use by about 35 million gallons per day (Peck and others, 2005).

In addition to continuous water-level monitoring, synoptic water-level measurements are made periodically, in cooperation with the St. Johns River Water Management District, in wells in and around the southern coastal area of Georgia and adjacent parts of Florida. During September 2006 and 2007, water levels were measured in wells completed in the Upper Floridan aquifer in northeastern Florida and southeastern Georgia and subsequently were used to construct potentiometric-surface maps of the aquifer (Kinnaman and Dixon 2007, 2008). The maps for 2006 and 2007 (insets, facing page) show that water generally flowed from west to east toward the Atlantic Ocean and toward pumping centers at Fernandina Beach and Jacksonville, Florida.

\section{References}

Kinnaman, S.L., and Dixon, J.F., 2007, Potentiometric surface of the Upper Floridan aquifer in the St. Johns River Water Management District and vicinity, Florida, September 2006: U.S. Geological Survey Open-File Report 2007-1215, 1 sheet.

Kinnaman, S.L., and Dixon, J.F., 2008, Potentiometric surface of the Upper Floridan aquifer in the St. Johns River Water Management District and vicinity, Florida, September 2007: U.S. Geological Survey Open-File Report 2008-1085, 1 sheet.

Peck, M.F., McFadden, K.W., and Leeth, D.C., 2005, Effects of decreased ground-water withdrawal on ground-water levels and chloride concentrations in Camden County, Georgia, and ground-water levels in Nassau County, Florida, from September 2001 to May 2003: U.S. Geological Survey Scientific Investigations Report 2004-5295; 36 p. Web-only publication available at http://pubs.usgs.gov/sir/2004/5295/.

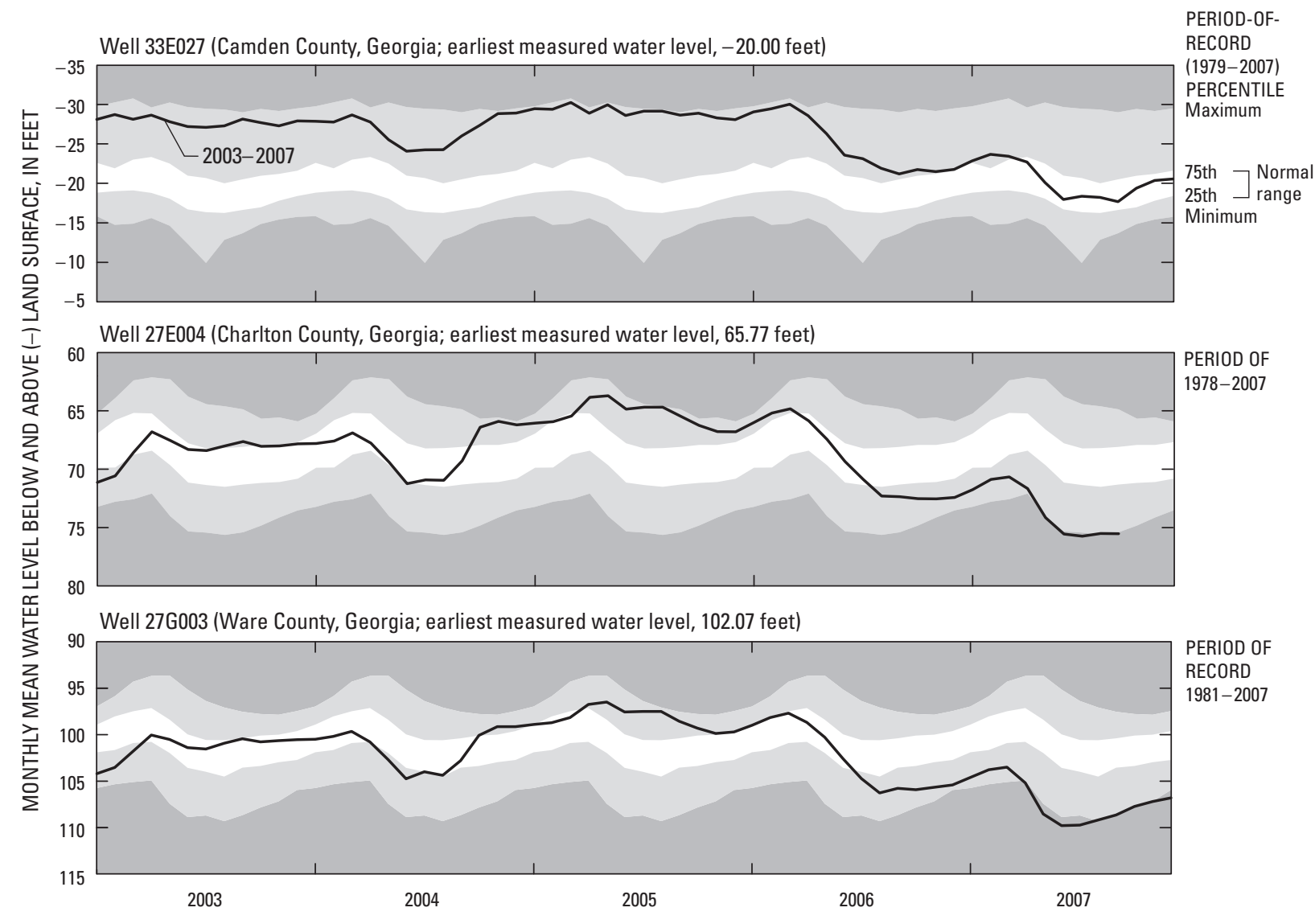




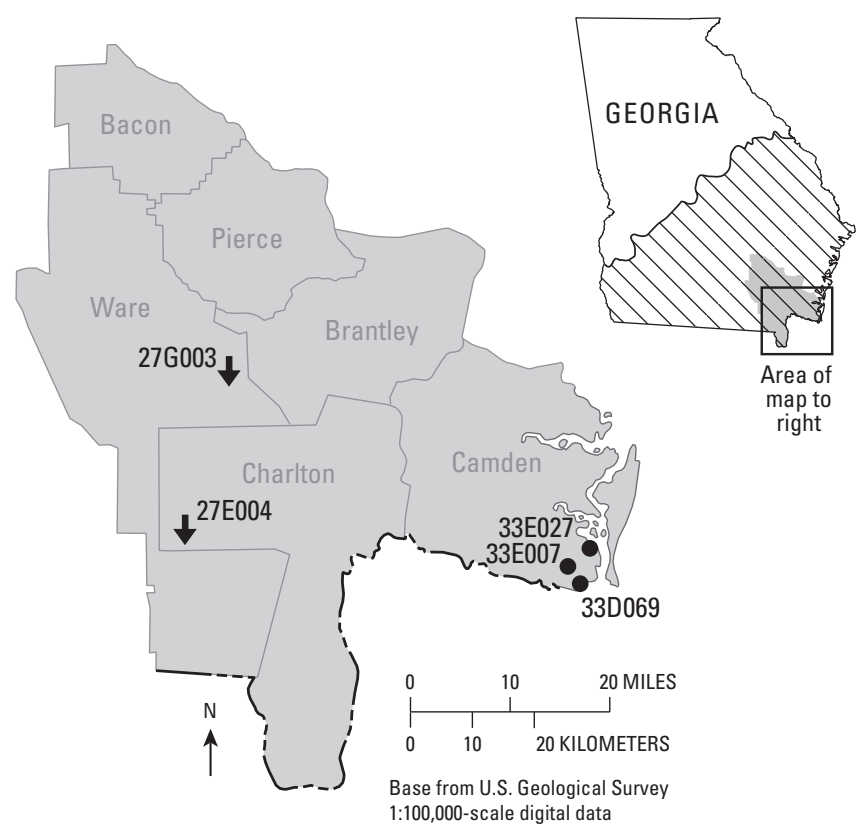

EXPLANATION

Upper Floridan aquifer

Southern coastal area

Observation well, site name, and comparison of monthly mean water level during 2007 to period-of-record water level

- 33D069 Normal-Between 25th and 75th percentile water levels for period of record

$\downarrow^{27 E 004}$ Below normal-Below 25th percentile water level for period of record

\begin{tabular}{|c|c|c|}
\hline Site name & County & Other identifier \\
\hline 33D069 & Camden & $\begin{array}{l}\text { U.S. National Park Service, Cumber- } \\
\text { land Island National Seashore }\end{array}$ \\
\hline 33Е007 & Camden & Huntly-Jiffy \\
\hline 33Е027 & Camden & U.S. Navy, Kings Bay, test well 1 \\
\hline 27E004 & Charlton & U.S. Geological Survey, test well OK-9 \\
\hline${ }^{1} 27 \mathrm{G} 003$ & Ware & U.S. Geological Survey, test well 1 \\
\hline
\end{tabular}

'Well is completed in both Upper and Lower Floridan aquifers;

most contribution is from the Upper Floridan aquifer.
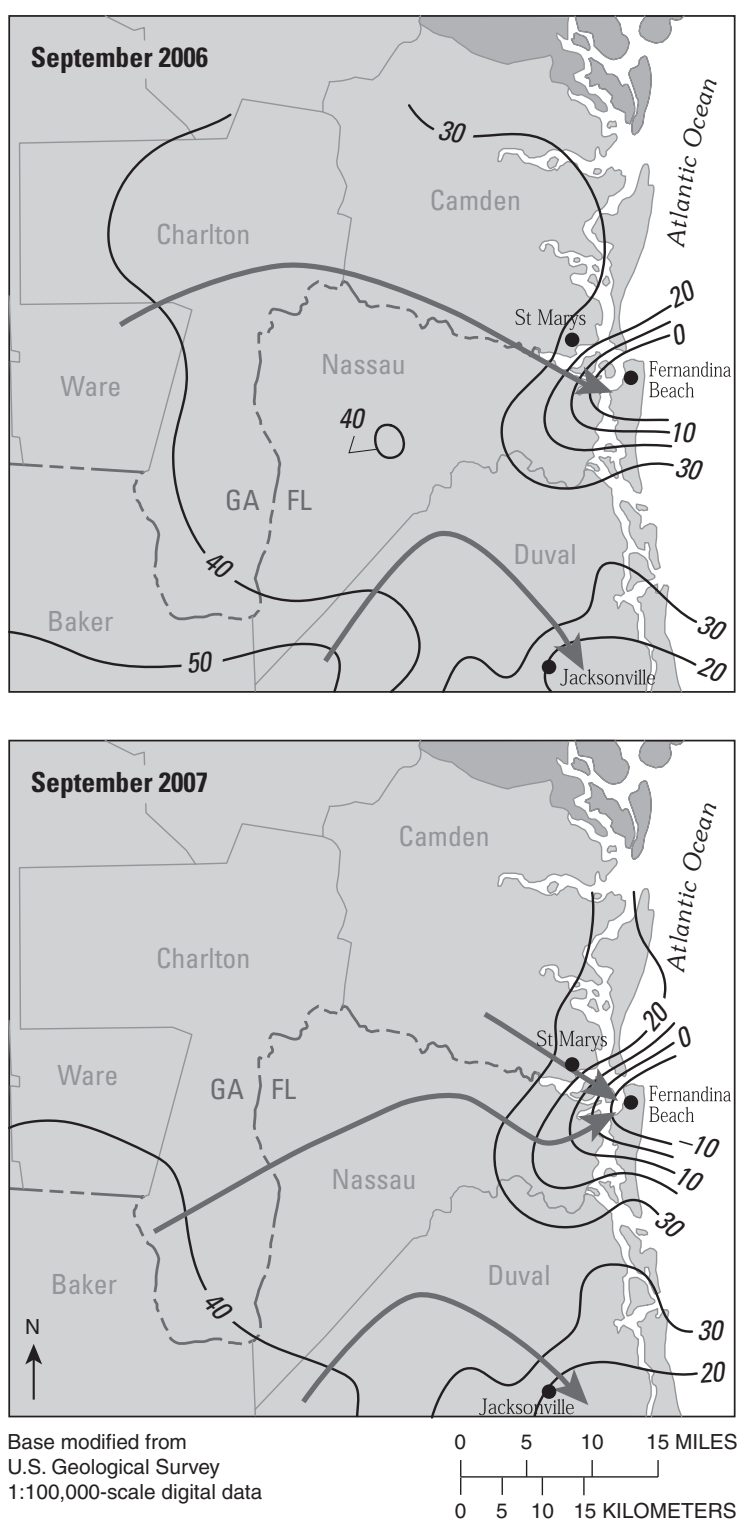

EXPLANATION

- 40 - Potentiometric contour-Shows altitude at which water level would have stood in tightly cased wells. Hachures indicate depressions. Contour interval 10 feet. Datum is North American Vertical Datum of 1988 (modified from Kinnaman and Dixon, 2007, 2008)

\section{Direction of ground-water flow}




\section{Ground-Water Levels}

\section{Lower Floridan Aquifer and Underlying Units in Coastal Georgia}

Water levels in 15 wells in central and southern coastal Georgia were used to define ground-water conditions in the Lower Floridan aquifer and underlying units during 2007 (map and table, facing page). In this area, water in the Lower Floridan aquifer is confined and influenced mostly by pumping. Water levels in six of the wells were below the normal range, in the normal range in seven wells, and above normal in two wells.

Hydrographs for four wells in the Lower Floridan aquifer in coastal Georgia (below) illustrate monthly mean water levels during 2003-2007 and period-of-record water-level statistics. Water levels in the four wells show a similar pattern and were generally in the normal to above-normal range during 2003 to mid-2006 when water levels began to decline to the normal to above-normal range except in well 33H188 in Glynn County, which reached a record-low water level during mid-2007. In well 33H188, a sharp decline in water level occurred during mid-2005 when the well was allowed to flow for a 24-hour period prior to water sampling during June 2005. The water level in the well fell during this period and remained at the lower level after flow was stopped. A record-high water level was recorded in well 38Q201 in Chatham County during mid-2006.

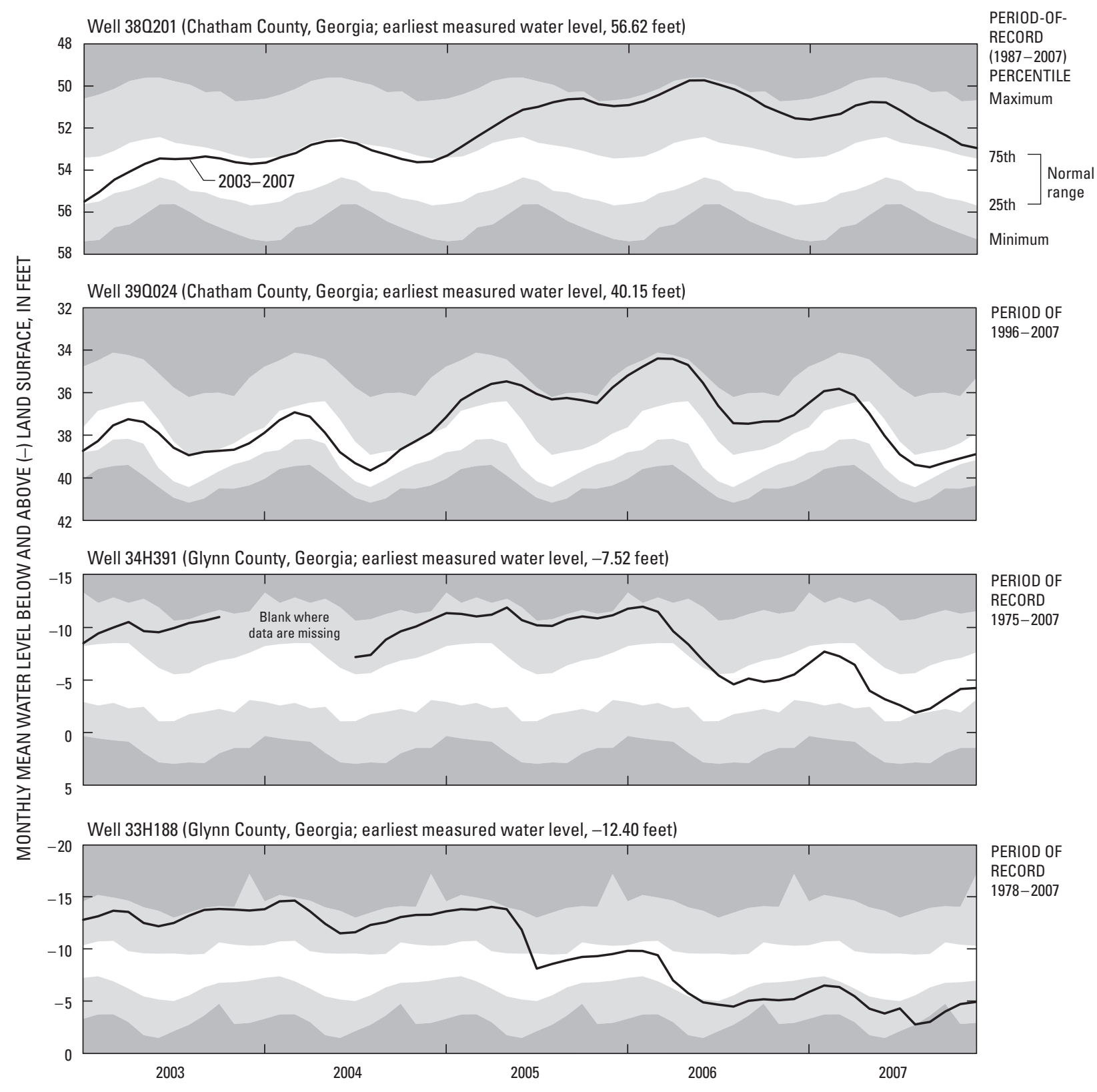



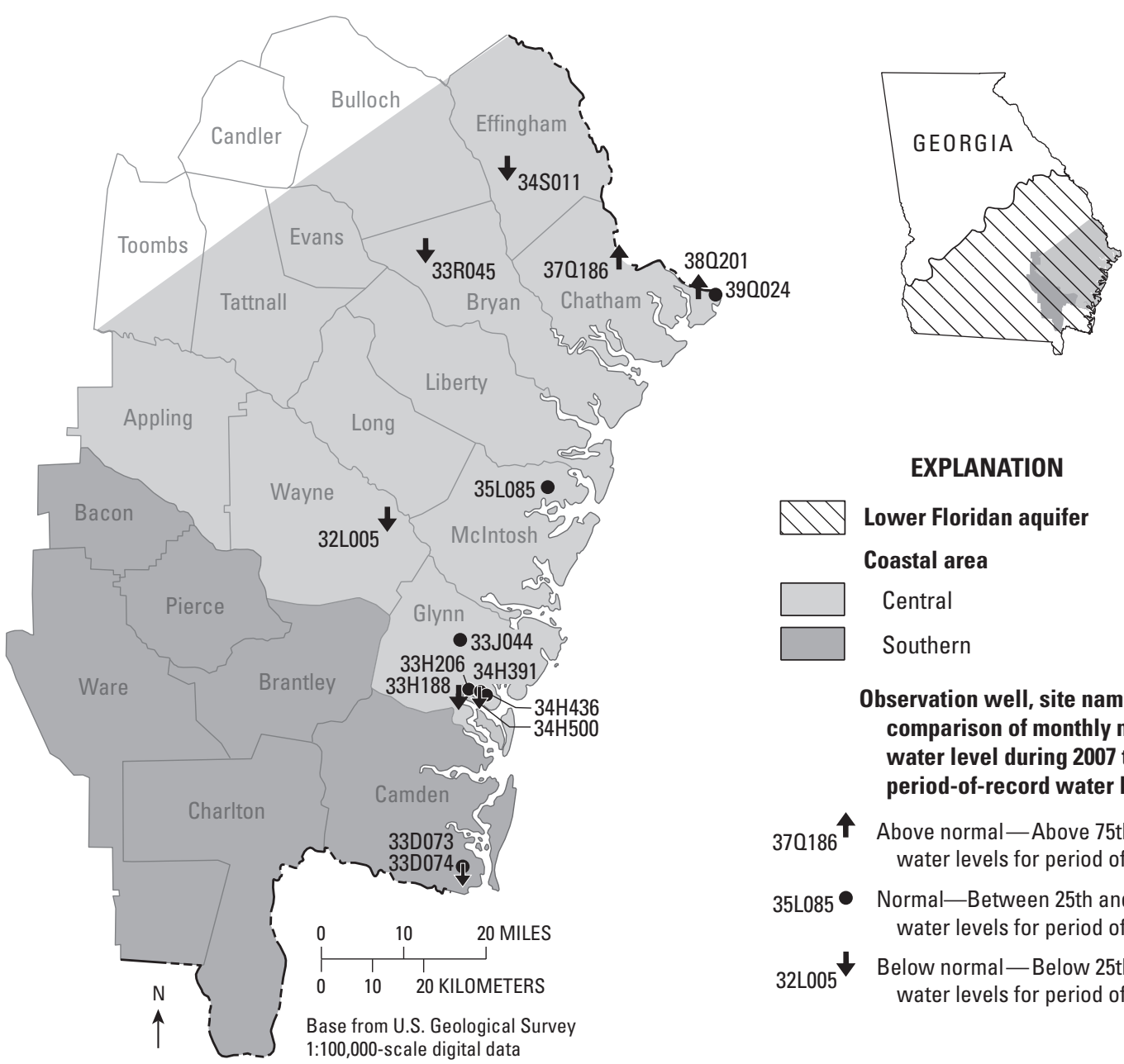

\section{EXPLANATION}

Lower Floridan aquifer

\section{Coastal area}

Central

Southern

Observation well, site name, and comparison of monthly mean water level during 2007 to period-of-record water level

370186 Above normal-Above 75th percentile water levels for period of record

$35 \mathrm{~L} 085 \bullet$ Normal-Between 25th and 75th percentile water levels for period of record

32L005 $\downarrow$ Below normal—Below 25th percentile water levels for period of record

\begin{tabular}{|c|c|c|c|}
\hline Site name & $\begin{array}{c}\text { Water-bearng } \\
\text { unit }^{1}\end{array}$ & County & Other identifier \\
\hline 33R045 & $\mathrm{LF}$ & Bryan & Coastal Sound Science Initiative test well \\
\hline 33D073 & $\mathrm{LF}$ & Camden & St. Marys, test well (deep) \\
\hline 33D074 & $\mathrm{LF}$ & Camden & Coastal Sound Science Initiative, St. Marys test well 2 \\
\hline 37Q186 & $\mathrm{P}$ & Chatham & Hutchinson Island, test well 2 \\
\hline 38Q201 & $P$ & Chatham & Georgia Geologic Survey, Fort Pulaski, test well \\
\hline 39Q024 & $\mathrm{LF}$ & Chatham & Georgia Geologic Survey, Tybee Island, test well 1 \\
\hline $34 \mathrm{~S} 011$ & $\mathrm{LF}$ & Effingham & Coastal Sound Science Initiative, Pineora Ball Park test well \\
\hline $33 \mathrm{H} 188$ & $\mathrm{~F}$ & Glynn & U.S. Geological Survey, test well 26 \\
\hline $33 \mathrm{H} 206$ & $\mathrm{LF}$ & Glynn & Georgia-Pacific, south, test well 1 \\
\hline 33J044 & $\mathrm{LF}$ & Glynn & U.S. Geological Survey, test well 27 \\
\hline 34H391 & $\mathrm{LF}$ & Glynn & U.S. Geological Survey, test well 16 \\
\hline $34 \mathrm{H} 436$ & $\mathrm{LF}$ & Glynn & Georgia Geologic Survey, Coffin Park, test well 1 \\
\hline $34 \mathrm{H} 500$ & $\mathrm{LF}$ & Glynn & U.S. Geological Survey, test well 30 \\
\hline $35 \mathrm{~L} 085$ & LF & McIntosh & Dan Hawthorne, test well 1 \\
\hline${ }^{2} 32 \mathrm{~L} 005$ & $\mathrm{LF}$ & Wayne & Hopkins No. 2 \\
\hline
\end{tabular}

'LF, Lower Floridan aquifer; P, Paleocene unit of low permeability; F, Fernandina permeable zone. ${ }^{2}$ Statistical comparison based on period of record less than 3 years. 


\section{Ground-Water Levels}

\section{Claiborne and Gordon Aquifers}

Water levels in 10 Claiborne aquifer wells and 1 Gordon aquifer well were used to define ground-water conditions in southwestern and east-central Georgia during 2007 (map and table, facing page). Water in the Claiborne and Gordon aquifers can be confined or unconfined. Water levels in wells completed in the Claiborne and Gordon aquifers were mostly below normal during 2007, likely reflecting effects of a drought that began in 2006. Water levels in seven of the wells were below normal, normal in two wells, and above normal in the remaining two wells.
Hydrographs showing water levels in two wells in the Claiborne aquifer and one well in the Gordon aquifer (below) illustrate monthly mean water levels during 2003-2007 and period-of-record water-level statistics. In the Claiborne wells, water levels generally rose during 2003 through early 2006. Water levels in wells 12L019 in Dougherty County and 06K010 in Early County were in the below-normal range during early 2003, rose to the normal to above-normal range by early 2006, and then declined to the normal to below-normal range by the end of 2007. The water level in the Gordon aquifer well 32 Y033 in Burke County was in the normal to below-normal range during most of 2003-2007. Water levels declined into the below-normal range during 2006 and remained there through the end of 2007 when record-low water levels were recorded.

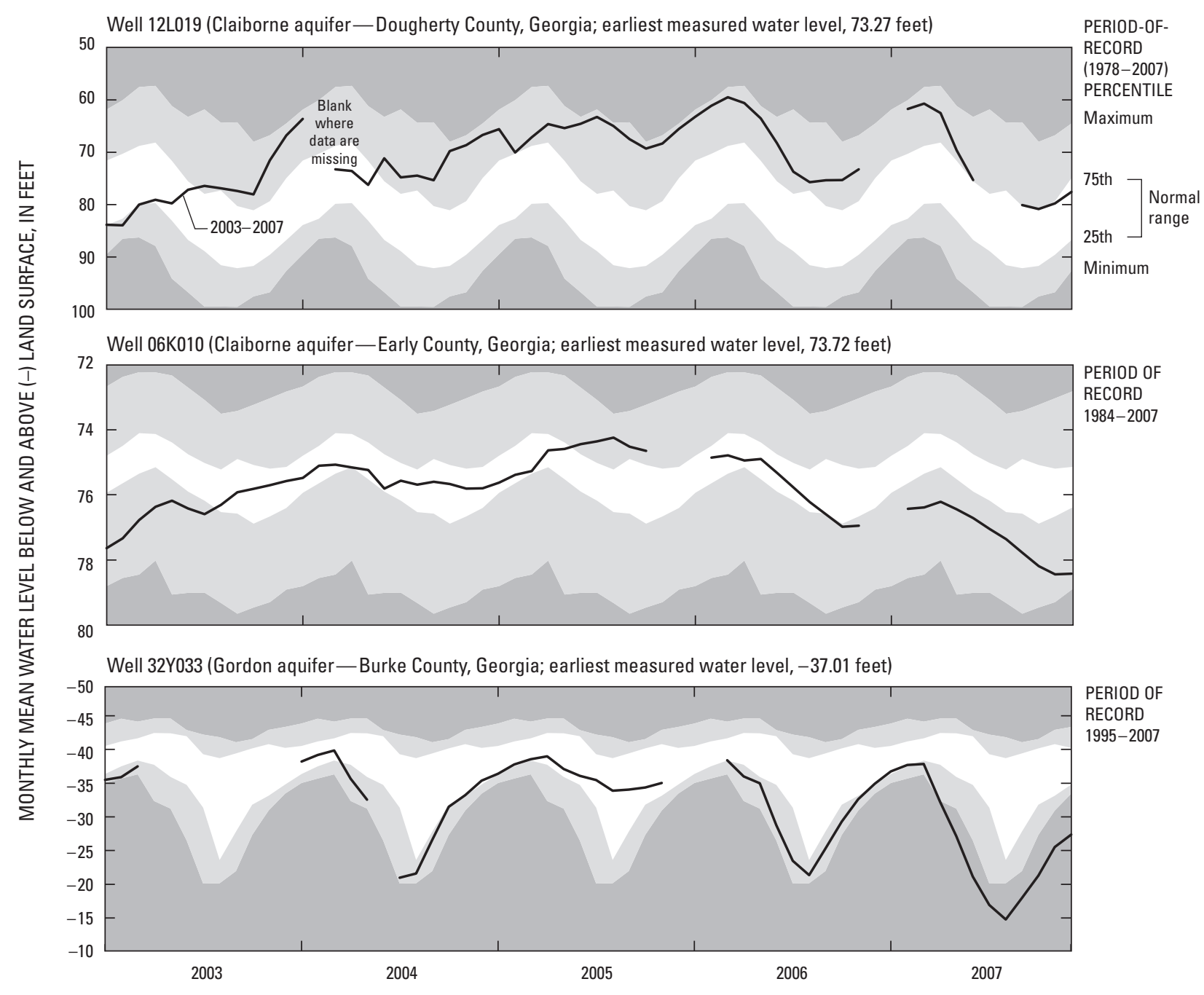



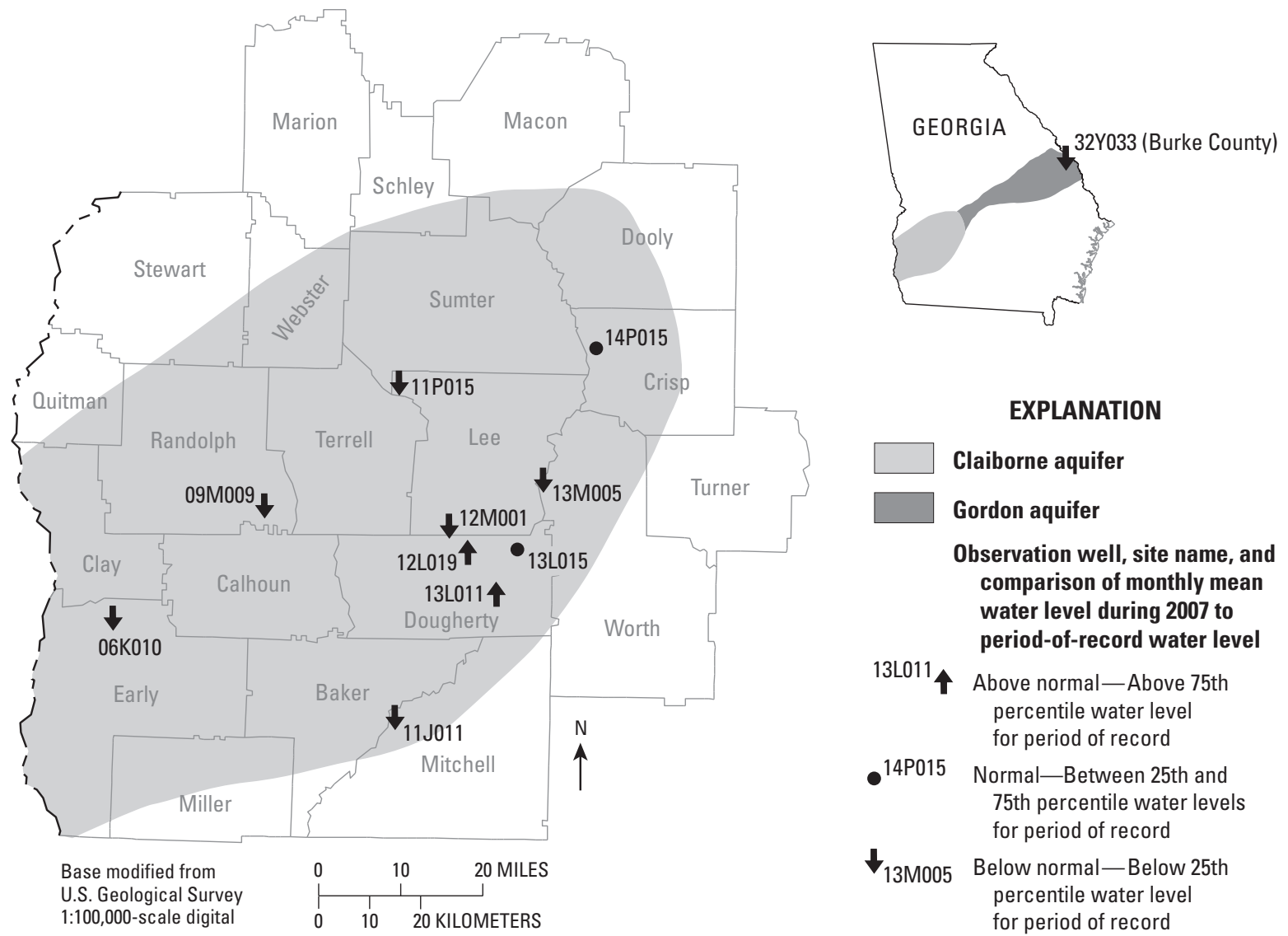

\section{EXPLANATION}

Claiborne aquifer

Gordon aquifer

Observation well, site name, and comparison of monthly mean water level during 2007 to period-of-record water level

13L011

Above normal-Above 75th percentile water level for period of record

14P015 Normal-Between 25th and 75th percentile water levels for period of record

$\downarrow$ 13M005 Below normal-Below 25th percentile water level for period of record

\begin{tabular}{|c|c|c|c|}
\hline Site name & $\begin{array}{c}\text { Water-bearing } \\
\text { unit }^{1}\end{array}$ & County & Other identifier \\
\hline 14P015 & $\mathrm{C}$ & Crisp & Georgia Geologic Survey, Veteran's Memorial State Park, test well 2 \\
\hline 12L019 & $\mathrm{C}$ & Dougherty & U.S. Geological Survey, test well 5 \\
\hline 13L011 & $\mathrm{C}$ & Dougherty & U.S. Geological Survey, test well 2 \\
\hline 13L015 & $\mathrm{C}$ & Dougherty & Miller Brewing Company \\
\hline 06K010 & $\mathrm{C}$ & Early & Georgia Geologic Survey, Kolomoki Mounds State Park, test well 3 \\
\hline 11P015 & $\mathrm{C}$ & Lee & Long, test well 2 \\
\hline 12M001 & $\mathrm{C}$ & Lee & U.S. Geological Survey, test well 8 \\
\hline $11 \mathrm{~J} 011$ & $\mathrm{C}$ & Mitchell & U.S. Geological Survey, test well DP-10 \\
\hline 09M009 & $\mathrm{C}$ & Randolph & Martin, test well 1 \\
\hline 13M005 & $\mathrm{C}$ & Worth & U.S. Geological Survey, test well DP-7 \\
\hline $32 Y 033$ & $\mathrm{G}$ & Burke & Brighams Landing, test well 3 \\
\hline
\end{tabular}

${ }^{1} \mathrm{C}$, Claiborne aquifer; $\mathrm{G}$, Gordon aquifer. 


\section{Ground-Water Levels}

\section{Clayton Aquifer}

Water levels in 11 wells were used to define ground-water conditions in the Clayton aquifer in southwestern Georgia during 2007 (map, facing page). In this area, water in the Clayton aquifer is confined and influenced mostly by pumping. During 2007, water levels in 7 of the 11 wells were below normal, and in the remaining 4 wells, water levels were normal in 2 and above normal in the other 2.

Hydrographs for three wells in the Clayton aquifer in southwestern Georgia (below) illustrate monthly mean water levels during 2003-2007 and period-of-record water-level statistics. All three wells show a decline beginning in early 2006 from the effects of a drought that began in 2006. During 2003-2007, water levels in well 13L002 in Dougherty County rose to within the normal range for most of the period but began to decline in early 2006 and were slightly below normal for a short period in 2007. The water level in well 07N001 in Randolph County remained below normal during the period 2003-2007 and began a decline in early 2005. Record-low water levels were recorded in this well during late 2007. Water level in well 14P014 rose from below normal to the normal range through mid-2006 when the water level began to decline to the below-normal range where it remained through the end of 2007.

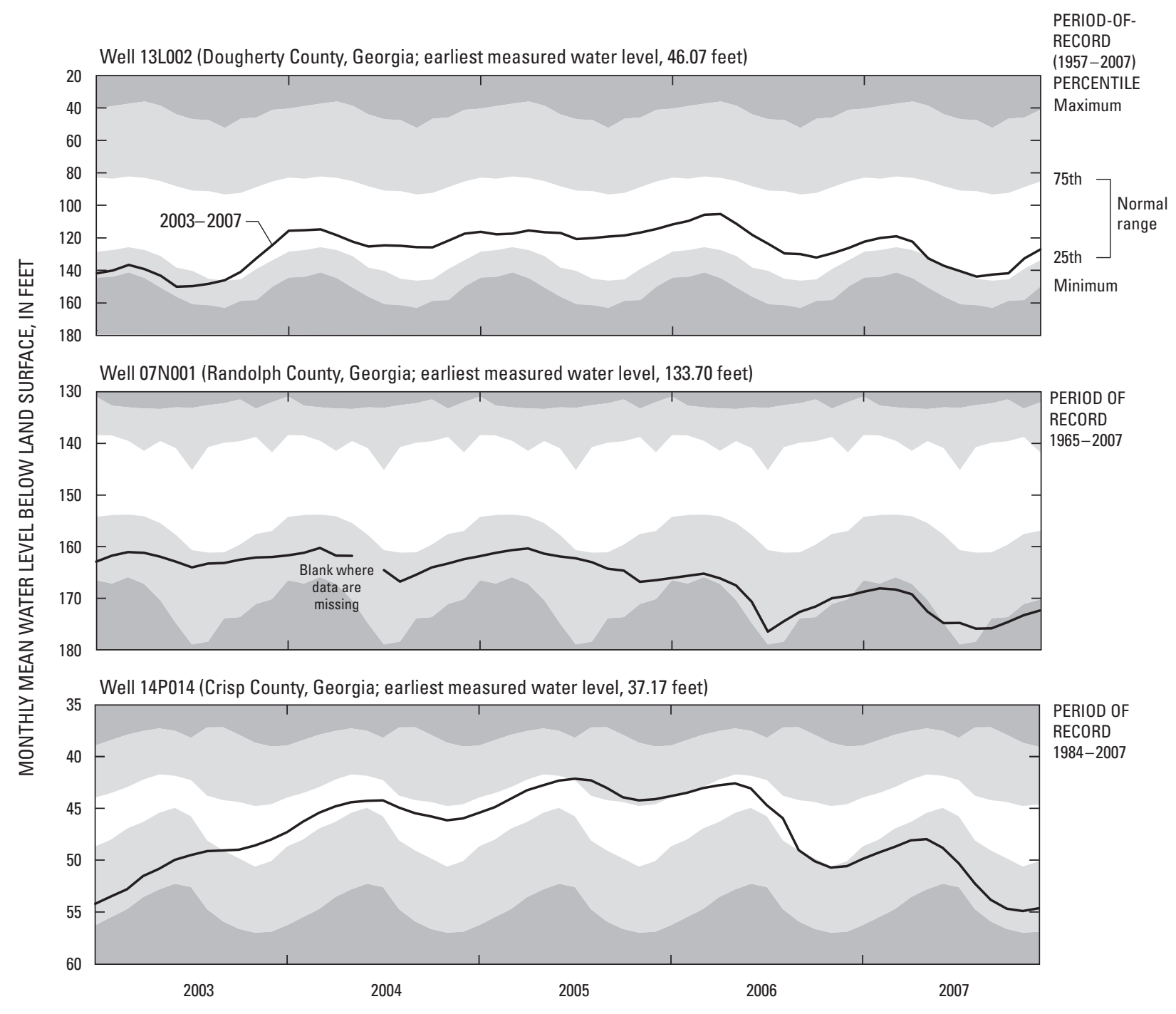



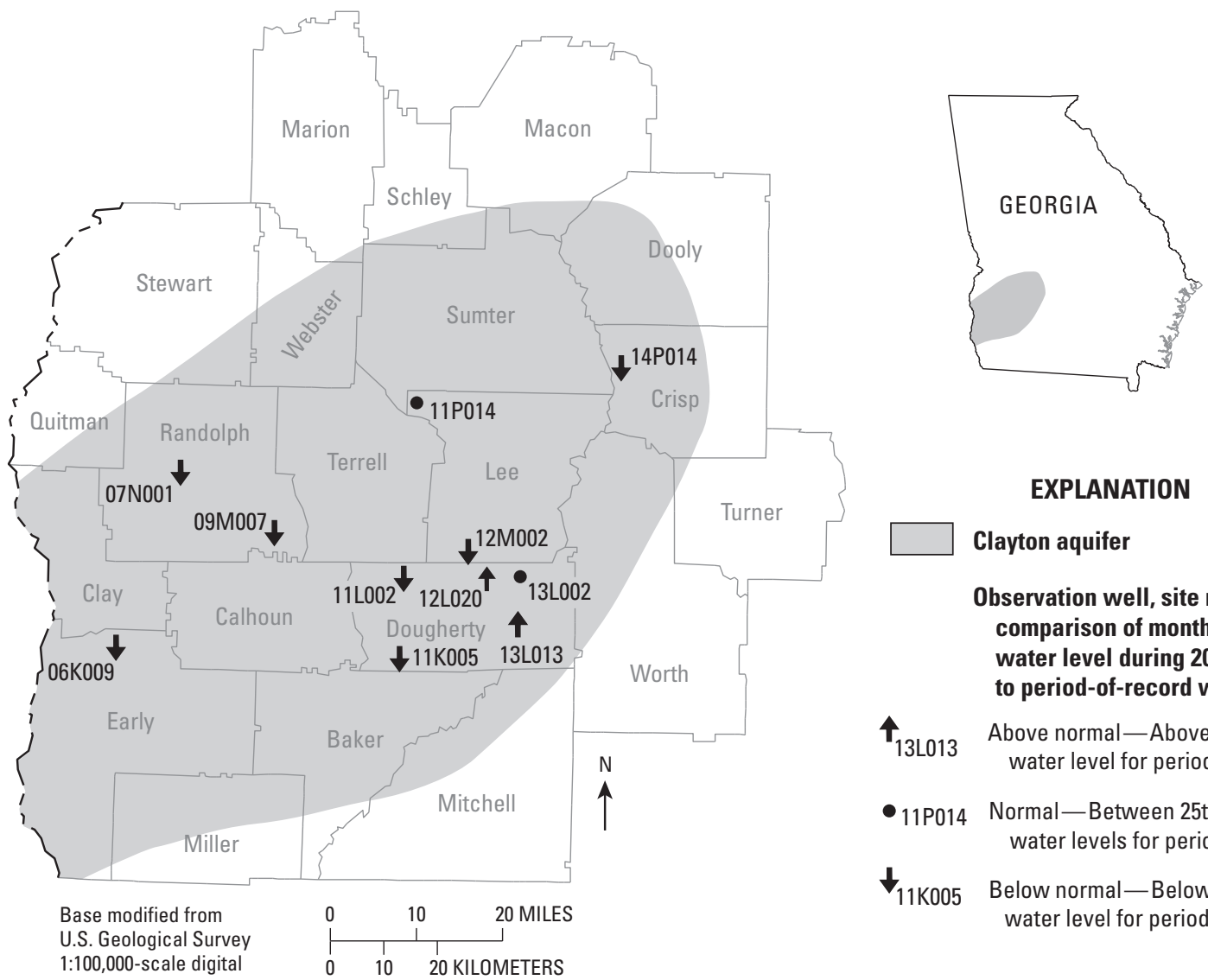

EXPLANATION

Clayton aquifer

Observation well, site name, and comparison of monthly mean water level during 2007 to period-of-record water level

$\boldsymbol{T}_{13 L 013}$ Above normal-Above 75th percentile water level for period of record

- 11P014 Normal-Between 25th and 75th percentile water levels for period of record

$\downarrow$ 11K005 Below normal-Below 25th percentile water level for period of record

\begin{tabular}{lll}
\hline Site name & County & \multicolumn{1}{c}{ Other identifier } \\
\hline 14 P014 & Crisp & Georgia Geologic Survey, Veteran's Memorial State Park, test well 1 \\
11K005 & Dougherty & U.S. Geological Survey, test well 12 \\
11L002 & Dougherty & Georgia Geologic Survey, Albany Nursery \\
12 L020 & Dougherty & U.S. Geological Survey, test well 6 \\
13L002 & Dougherty & Albany Water, Gas, and Light Commission, Turner City 2 \\
13L013 & Dougherty & U.S. Geological Survey, test well 7 \\
06K009 & Early & Georgia Geologic Survey, Kolomoki Mounds State Park, test well 1 \\
11P014 & Lee & Long, test well 1 \\
12M002 & Lee & U.S. Geological Survey, test well 9 \\
07N001 & Randolph & City of Cuthbert \\
09 M007 & Randolph & Martin, TW-2 \\
\hline
\end{tabular}




\section{Ground-Water Levels}

\section{Cretaceous Aquifer System}

Water levels in 12 wells in the Cretaceous aquifer system were used to define ground-water conditions throughout central and southwestern Georgia during 2007 (map and table, facing page). In this area, water in the Cretaceous aquifer system mostly is confined but can be unconfined in stream valleys. Water levels in 10 of the wells were in the below-normal range during 2007, reflecting continued declines related to groundwater pumping. Water levels in two wells were within or above the normal range.

Hydrographs for three wells in the Cretaceous aquifer in central and southwestern Georgia (below) illustrate monthly mean water levels during 2003-2007 and period-of-record waterlevel statistics. Water levels in well 28X001 in Burke County and well 06S001 in Muscogee County were below the normal range during most of 2003-2007. In well 28X001, water level reached record lows during 2003 and 2007 and remained below normal through 2007. In well 12L021 in Dougherty County, the water level was below normal during early 2003 then rose to above normal in early 2004 and remained above normal through 2007. The effects of long-term water-level decline are apparent from the hydrograph of well 06S001, which has had little change in water level during the past 5 years, although it has had heavy continual agricultural pumping. A record-low water level was recorded in this well at the end of 2007.

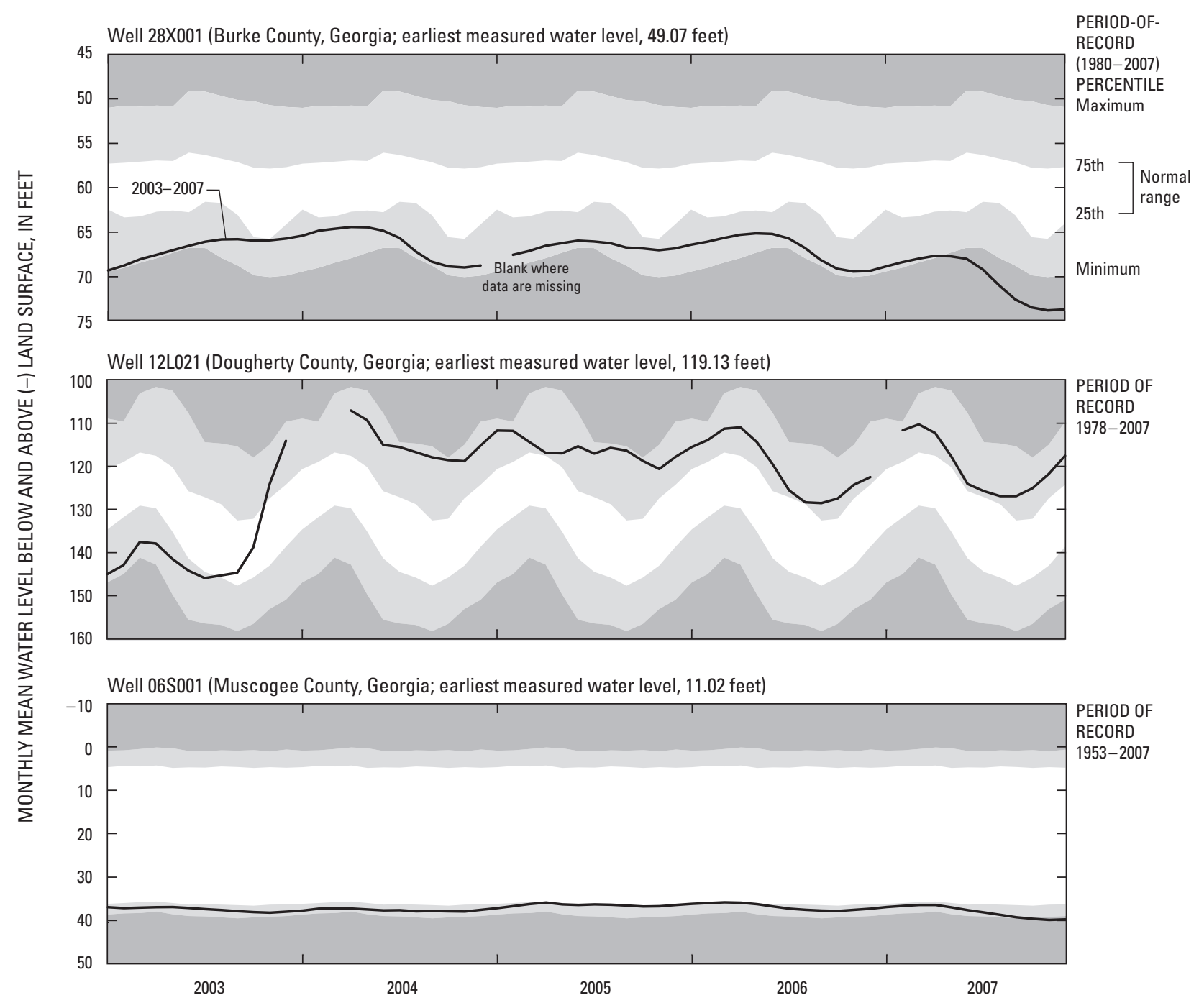




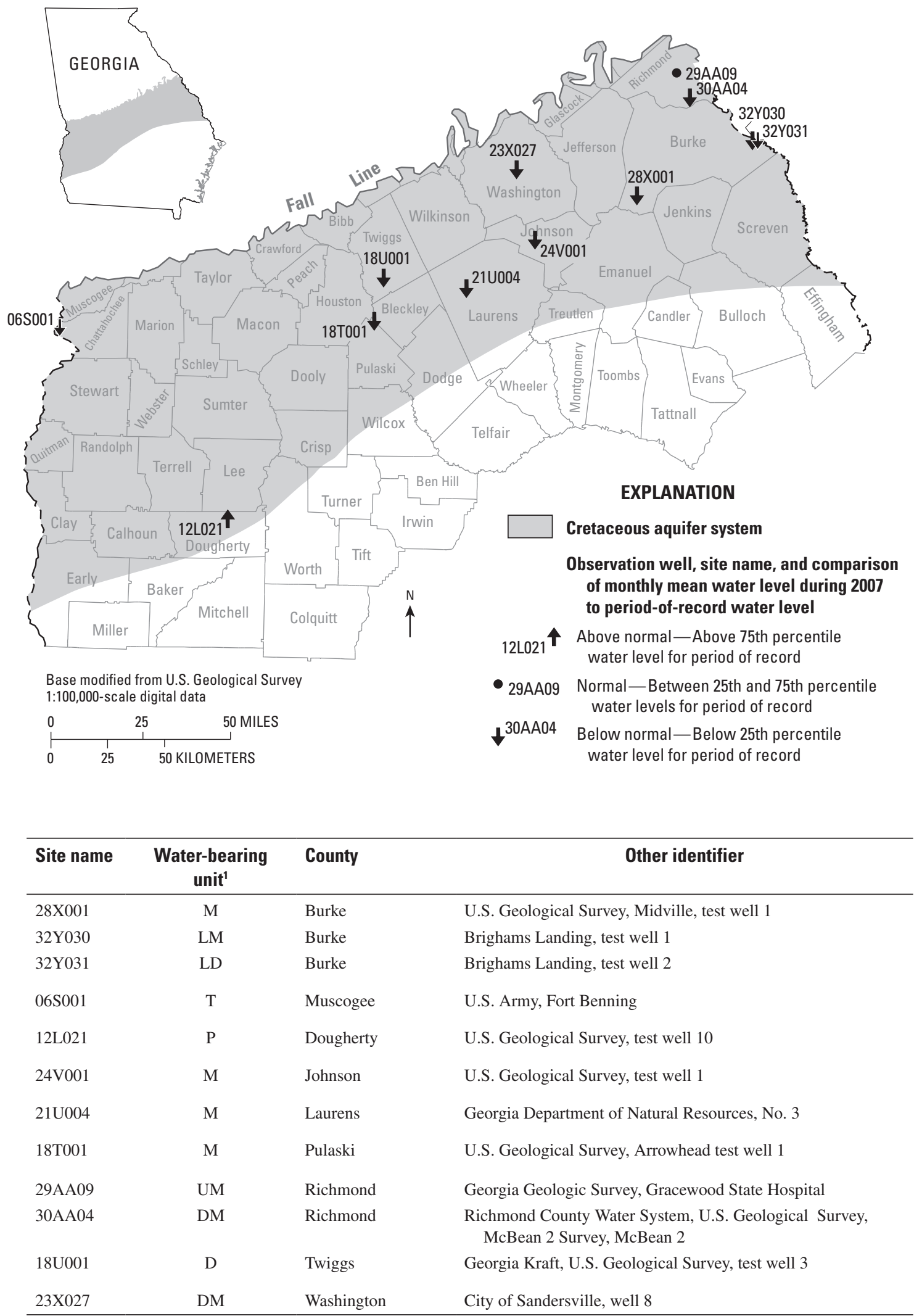

${ }^{1} M$, Midville aquifer system; LM, Lower Midville aquifer; LD, Lower Dublin aquifer; T, Tuscaloosa Formation; P, Providence aquifer; UM, Upper Midville aquifer; DM, Dublin-Midville aquifer system; D, Dublin aquifer system. 


\section{Ground-Water Levels}

\section{Paleozoic-Rock Aquifers}

Water levels were measured in two wells in the Paleozoic-rock aquifers of northwestern Georgia during 2007 (map and table, facing page). In this area, water in the Paleozoic-rock aquifers is under confined conditions. Water levels were within the normal range in one well and below normal in the other well.

Hydrographs for the two wells in the Paleozoic-rock aquifer in northwestern Georgia (below) illustrate monthly mean water levels during 2003-2007 and period-of-record waterlevel statistics. The U.S. Geological Survey monitors only two wells in this aquifer; therefore, these statistics represent only a limited area and not the aquifer as a whole. The water level in well 07KK64 in Gordon County was normal or above normal through early 2004 when it declined to below normal, then rose to normal and above-normal levels through early 2006. In 2006 the water level declined to below normal through 2007, and record-low water levels were recorded in this well in mid-2007. The water level in well 03PP01 in Walker County was normal or above normal during 2003-2007.

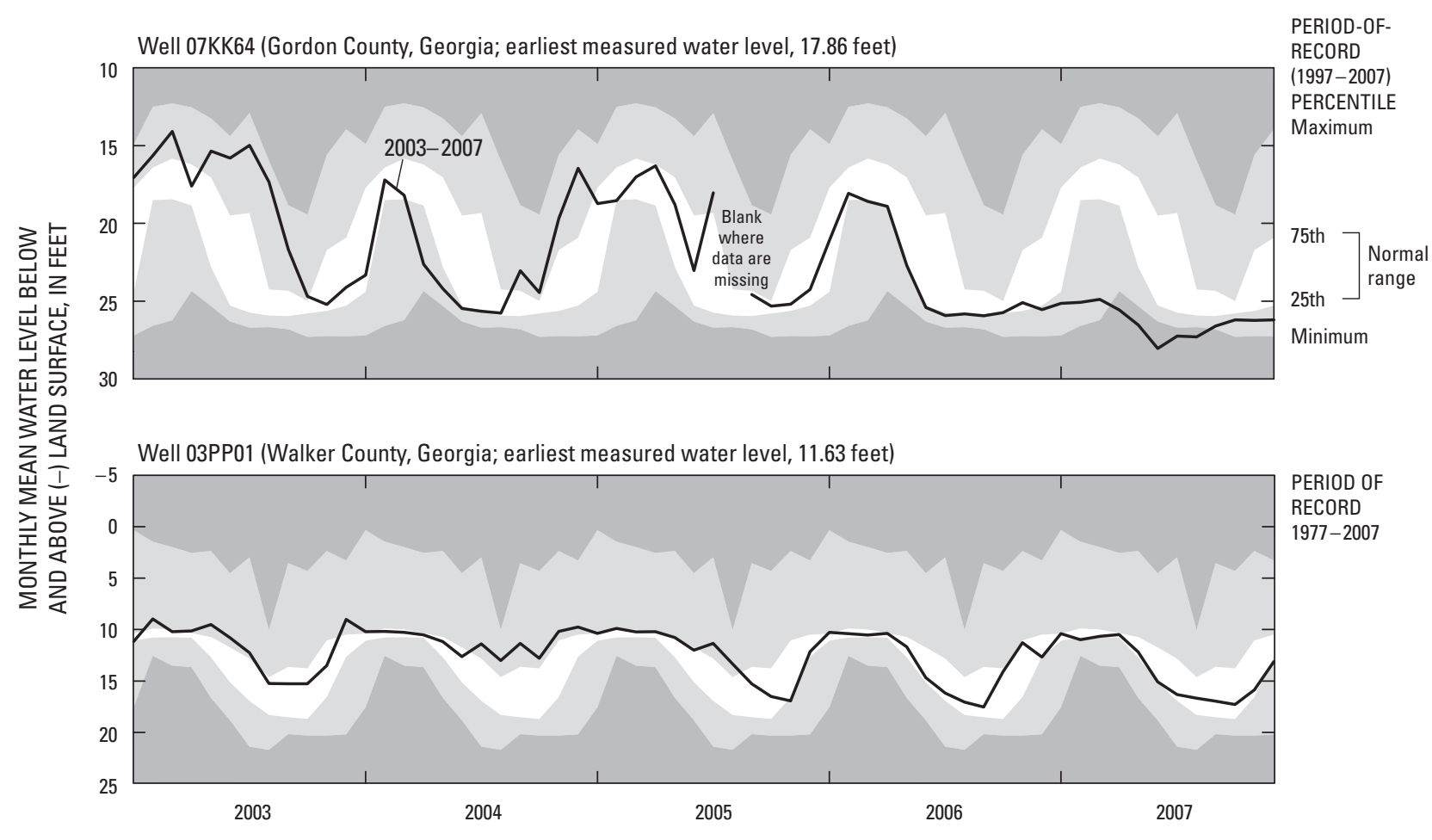



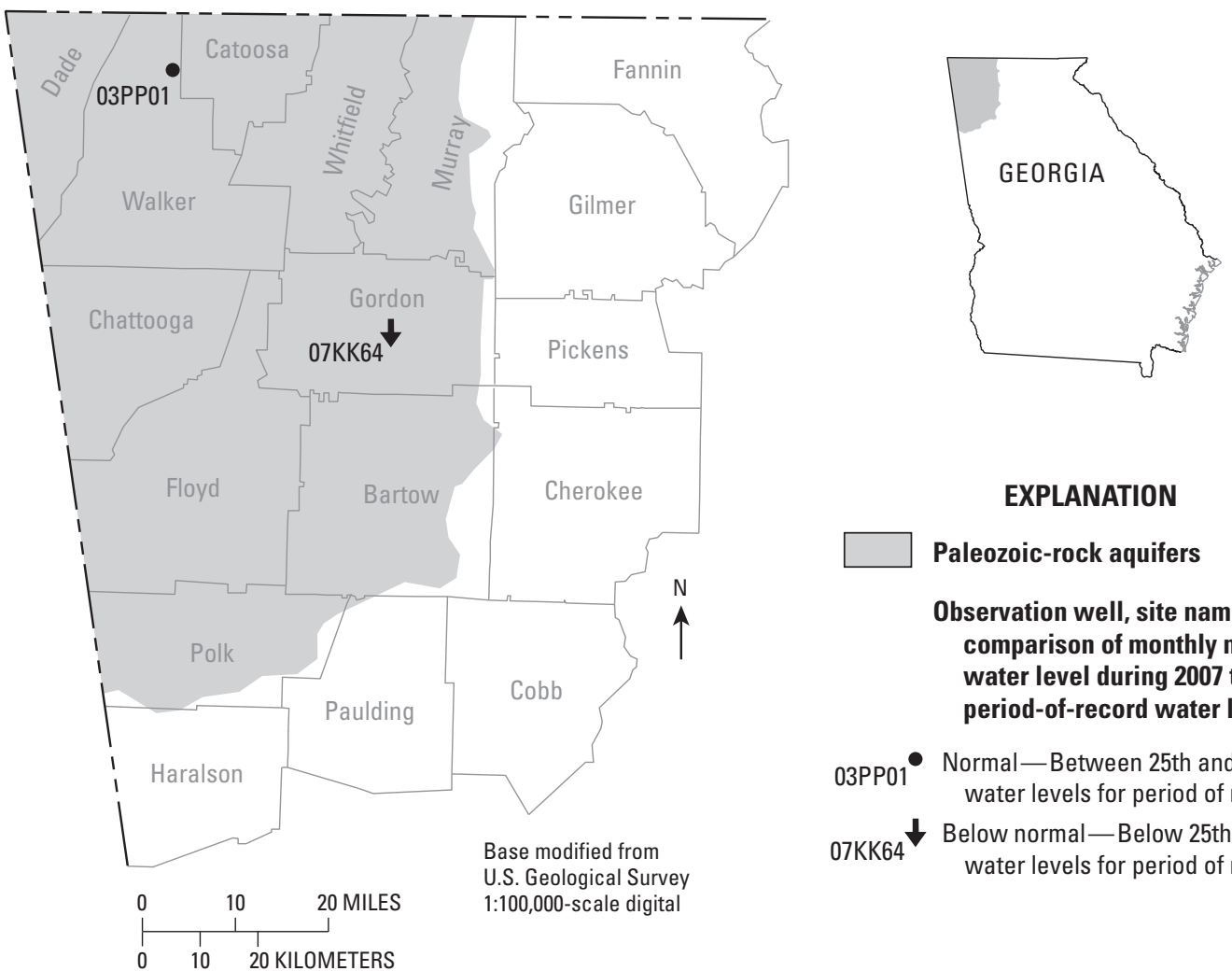

\section{EXPLANATION}

Paleozoic-rock aquifers

Observation well, site name, and comparison of monthly mean water level during 2007 to period-of-record water level

03PP01 Normal-Between 25th and 75th percentile water levels for period of record

07KK64 $\downarrow$ Below normal-Below 25th percentile water levels for period of record

\begin{tabular}{lll}
\hline Site name & County & Other identifier \\
\hline 07KK64 & Gordon & Calhoun, Georgia, test well 1 \\
03PP01 & Walker & U.S. National Park Service, Chickamauga Battlefield Park \\
\hline
\end{tabular}




\section{Ground-Water Levels}

\section{Crystalline-Rock Aquifers}

Water levels in nine wells were measured in crystalline-rock aquifers in the Piedmont and Blue Ridge physiographic provinces of Georgia during 2007 (map and table, facing page). In this area, water is present in discontinuous joints and fractures and may be confined or unconfined. In general, crystalline-rock aquifers have local extent and can be greatly affected by localized water use and climate. Water levels in eight of the wells were below normal during 2007.
Hydrographs for three wells in the crystalline-rock aquifer (below) illustrate monthly mean water levels during 2003-2007 and period-of-record water-level statistics. During 2003, water levels were in the normal to above-normal range; then during 2004 through early 2006, water levels ranged from normal to below normal, and remained in the below-normal range through 2006-2007. The water level in well 10DD02 in Fulton County was in the normal range during 2003 and through mid-2007, when it declined to the below-normal range and record-low water levels were recorded. The water level in well 21BB04 in Greene County ranged from above to below normal from 2003 through 2006, then declined to below normal through 2007 when record-low water levels were recorded.

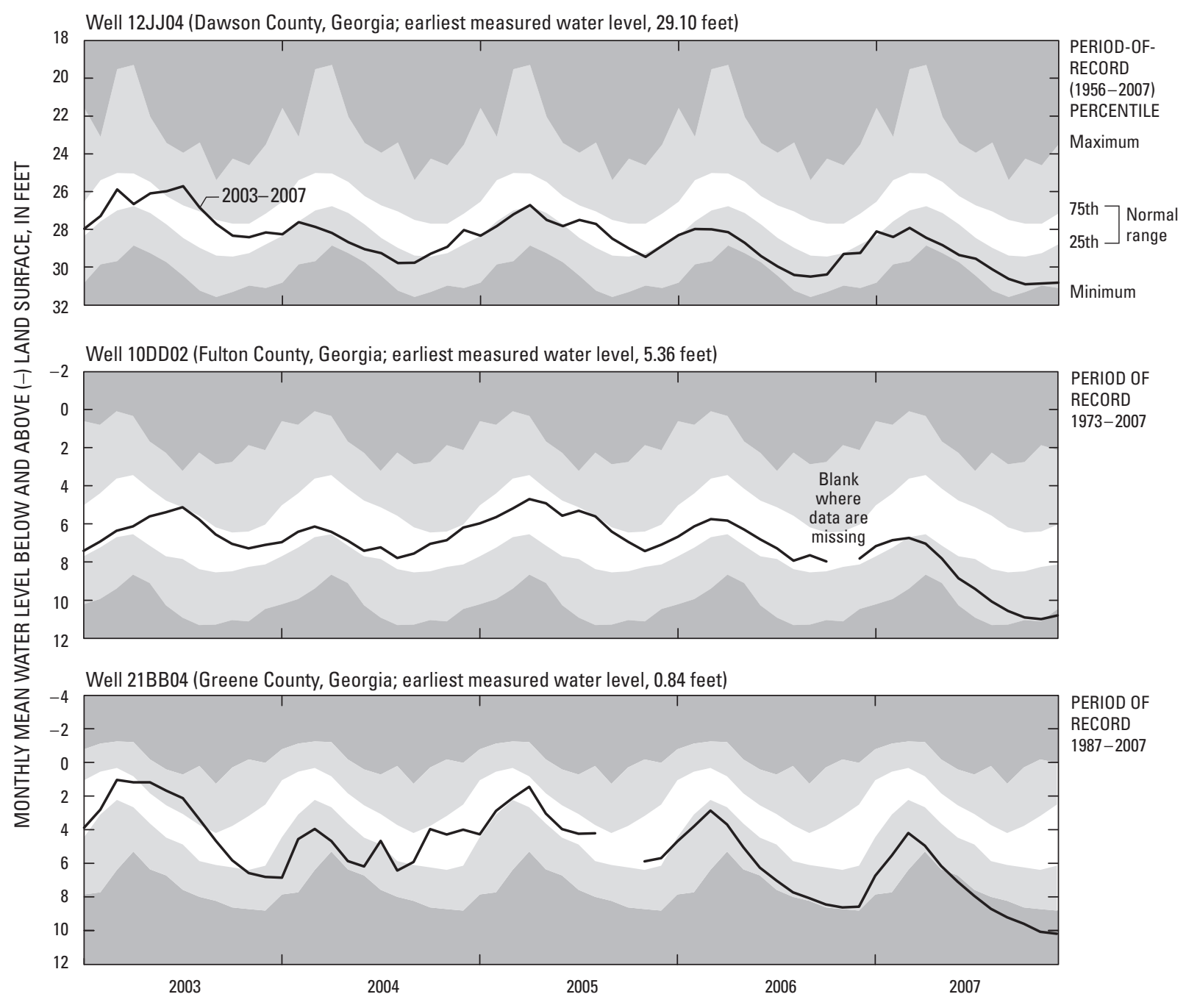




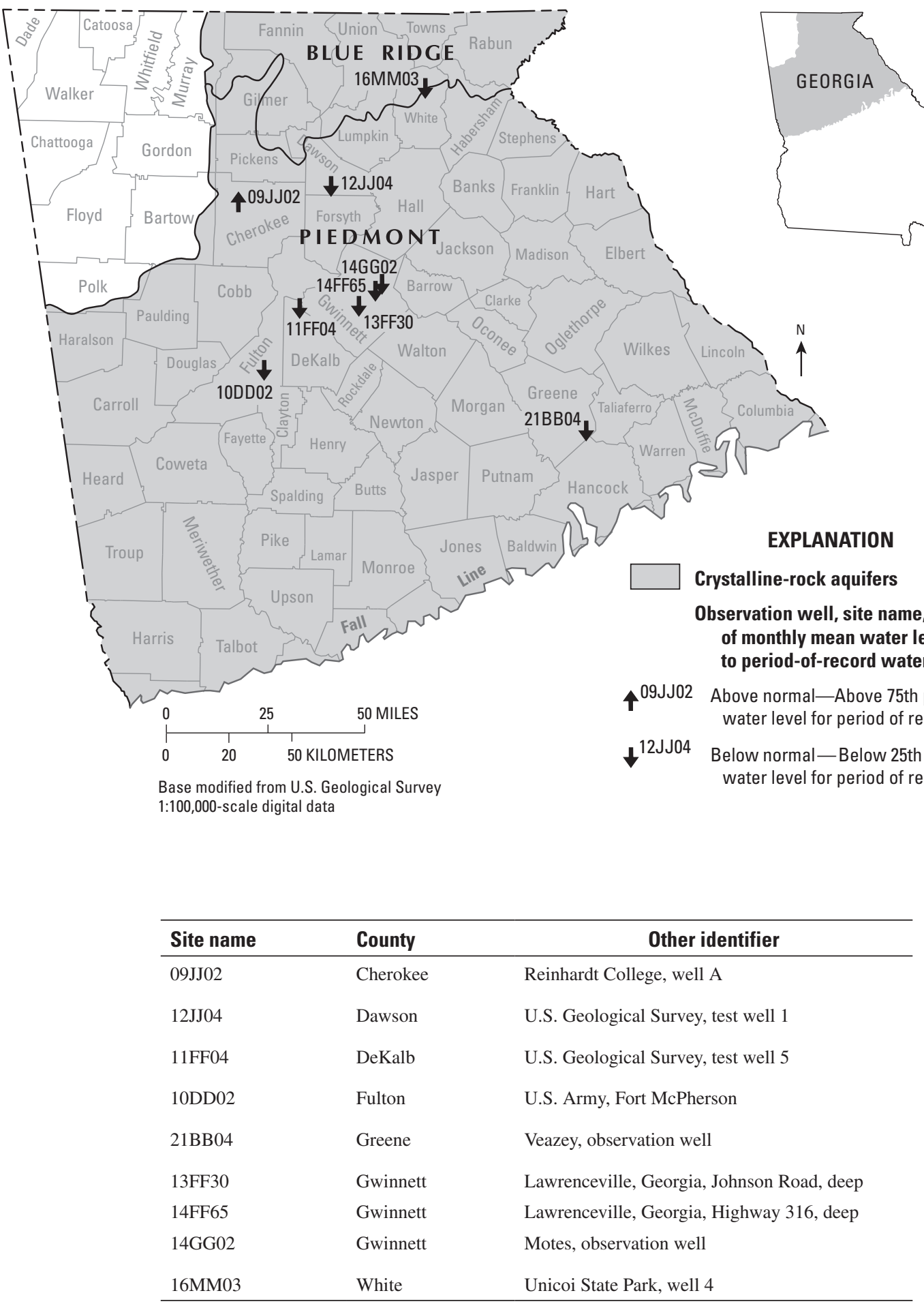





\section{Ground-Water Quality in the Upper and Lower Floridan Aquifers}

The quality of water from the Upper and Lower Floridan aquifers is monitored in the Albany and coastal areas. In the south-central part of Dougherty County near Albany, wells are monitored annually for nitrate concentrations. In coastal Georgia, chloride concentration in water from the Upper and Lower Floridan aquifers has been monitored since the 1950s in the Savannah and Brunswick areas and since the early 1990s in the Camden County area.

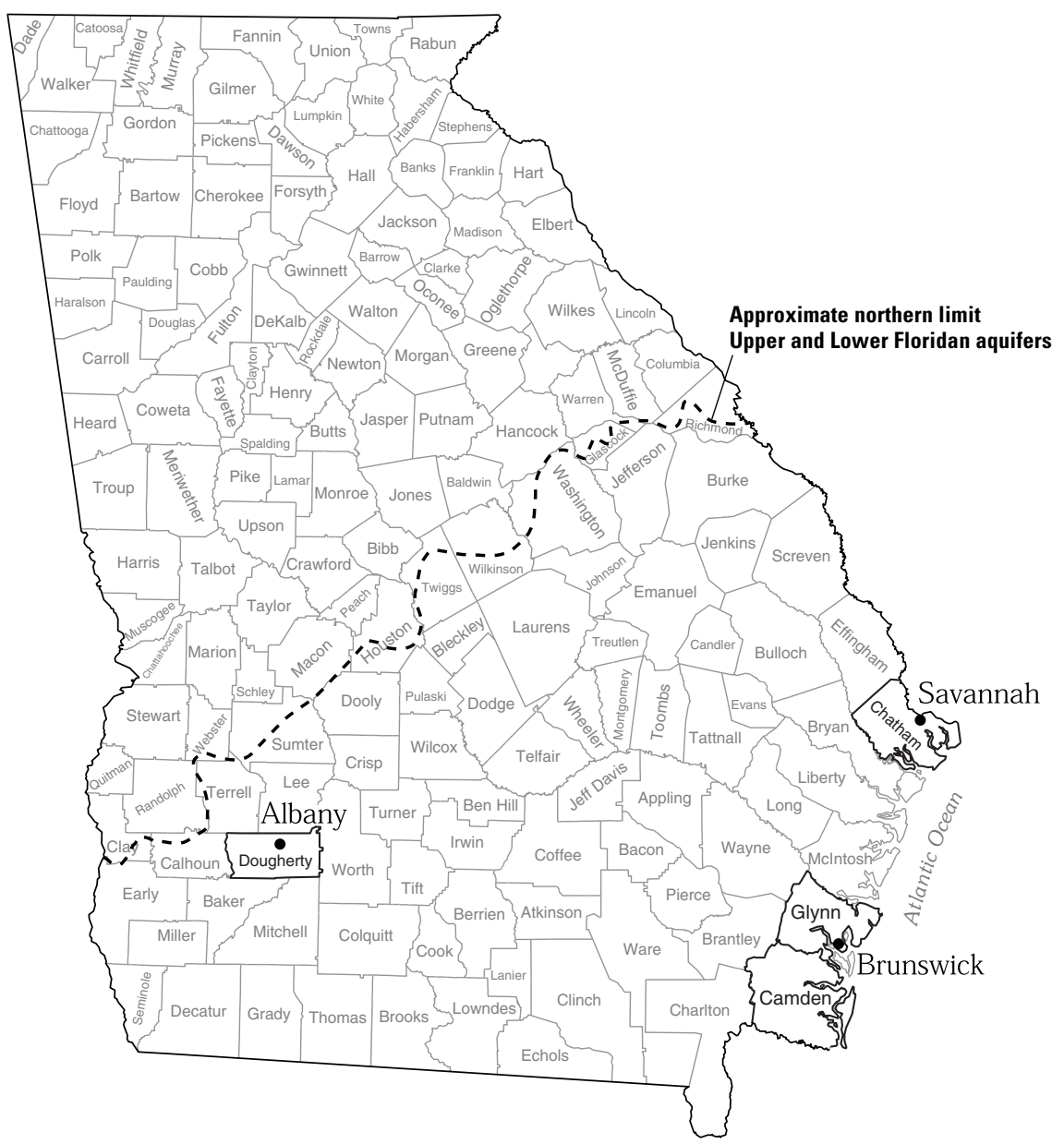




\section{Ground-Water Quality in the Upper and Lower Floridan Aquifers}

\section{City of Albany Area}

The Upper Floridan aquifer is shallow in southwestern Georgia where agricultural land use is prevalent, which increases the susceptibility of ground water to contamination from nitrates and other chemicals. Monitoring may provide an early warning of potential contamination of water supplies. Nitrate levels greater than 10 milligrams per liter $(\mathrm{mg} / \mathrm{L})$, the maximum contaminant level for nitrate set by the U.S. Environmental Protection Agency (2000), have been measured in wells southwest of Albany.

Nitrate as nitrogen $(\mathrm{N})$ concentrations have been measured in the southwestern Albany area at least annually since September 1998. During November 2006 and October 2007, samples were collected from selected wells (13 and 12, respectively) and at one site on the Flint River. Since the end of a prolonged drought period during 2002, nitrate concentrations generally have increased in the area; however, concentrations decreased slightly in several wells during 2007 (graph, below).
During 2006, nitrate concentrations increased in 7 of the 13 ground-water samples. Of the samples collected during November 2006, water from two wells had nitrate as $\mathrm{N}$ concentrations greater than $10 \mathrm{mg} / \mathrm{L}$. By October 2007, water from only one well had a nitrate as $\mathrm{N}$ concentration greater than $10 \mathrm{mg} / \mathrm{L}$ ( $A$, facing page).

Samples collected during November 2006 and October 2007 were plotted on trilinear diagrams. These diagrams $(B$, facing page) show that ground-water samples remain chemically distinct from the surface-water sample. Ground-water samples had a lower sodium, potassium, and magnesium content and a higher carbonate and bicarbonate content than the surfacewater sample.

\section{References}

U.S. Environmental Protection Agency, 2000, Maximum contaminant levels (Part 143, National Secondary Drinking Water Regulations): U.S. Code of Federal Regulations, Title 40, Parts 100-149, rev. as of July 1, 2000, p. 612-614.

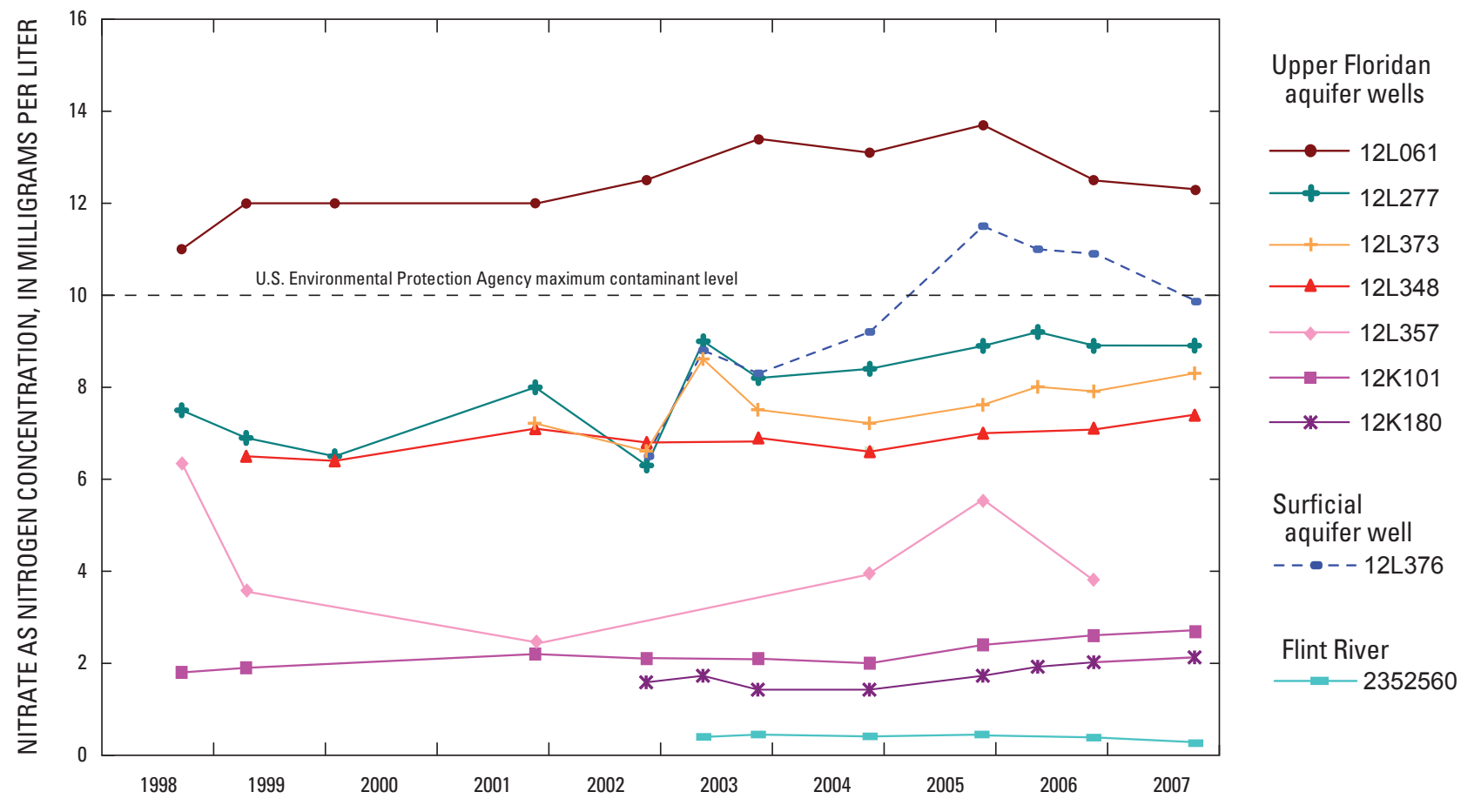

Nitrate as nitrogen concentrations in water from selected wells and the Flint River, from September 1998 through October 2007. 


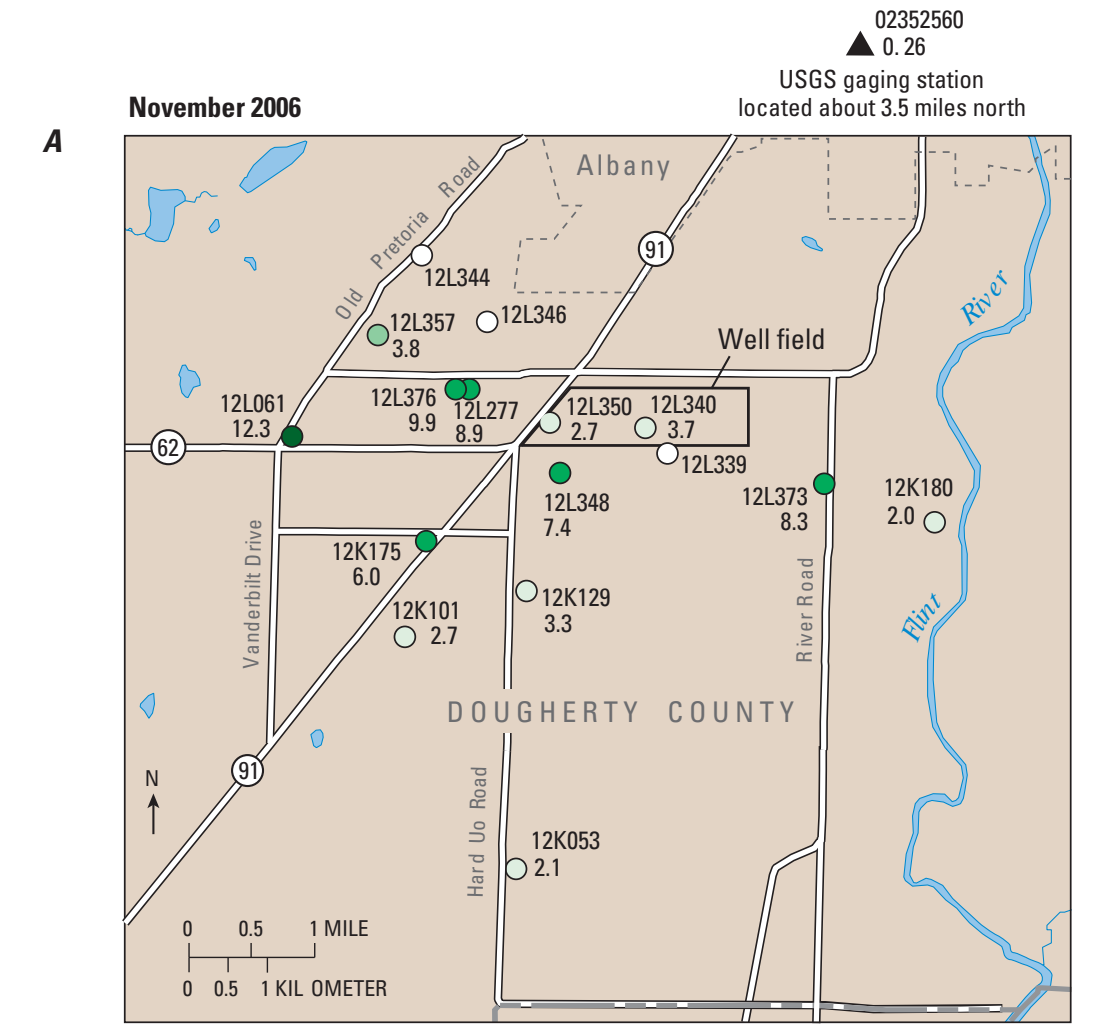

Base from U.S. Geological Survey 1:100,000-scale digital data
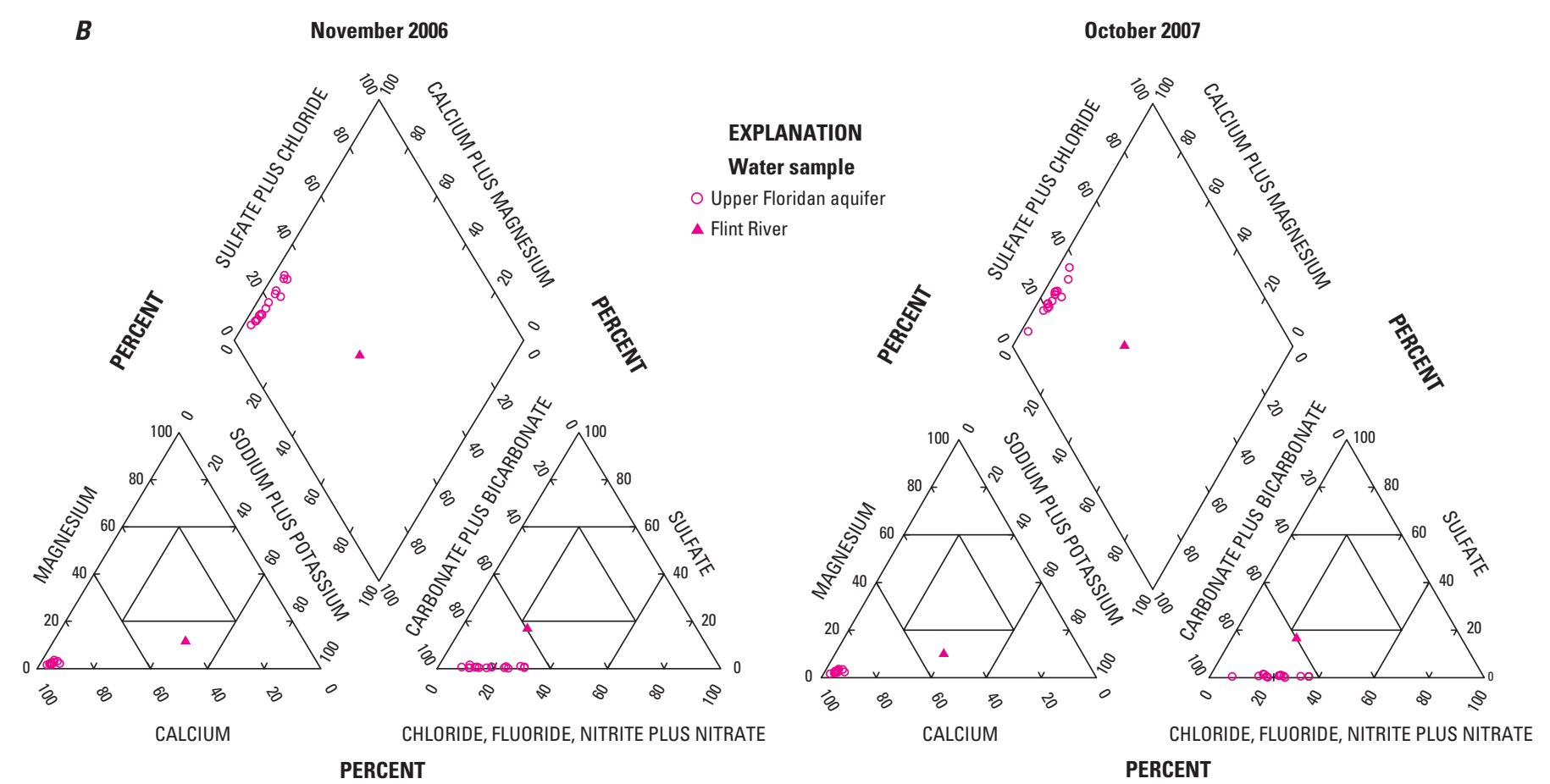

(A) Southwestern Albany area showing nitrate $\left(\mathrm{NO}_{3}\right)$ as nitrogen $(\mathrm{N})$ concentrations, October 2007; and (B) major cation and anion compositions of water samples from the Upper Floridan aquifer and the Flint River, November 2006 and October 2007. 


\section{Ground-Water Quality in the Upper and Lower Floridan Aquifers}

\section{City of Savannah Area}

During 2006-2007, borehole geophysical logs and water samples were collected from open intervals in wells completed in the Upper and Lower Floridan aquifers to assess changes in chloride concentration in the Savannah area, as part of a continuing program that started during 2003 (Leeth and others, 2007). Borehole geophysical logs include fluid resistivity, an indicator of dissolved-solids concentration, and fluid temperature, an indicator of possible breaches in the well casing that could compromise the reliability of water-quality measurements. The inverse of fluid resistivity is fluid conductivity, which is reported in units of specific conductance, in microsiemens per centimeter $(\mu \mathrm{S} / \mathrm{cm})$ at 25 degrees Celsius. High values reflect high concentrations of dissolved solids, which are mostly composed of dissolved chloride in the Savannah area. Water samples were collected at specific intervals to determine chloride concentration; analytical results are summarized in a table and shown with graphs on the facing page.

At Tybee Island, fluid conductivity (resistivity) logs and water samples were collected December 12, 2006, and December 4, 2007, from well 39Q024 completed in the Lower Floridan aquifer. The fluid resistivity logs collected during 2006-2007 indicated no changes or breaches in the well casing, and the mean specific conductance in the open borehole decreased slightly from 10,870 to $9,769 \mu \mathrm{S} / \mathrm{cm}$ during the period. Chloride concentrations of samples collected at common depths in well 39Q024 also decreased during 2006-2007, which is consistent with a downward trend that began during 2005 (A, facing page). During 2006 and 2007, chloride concentrations in samples collected at a depth of 845 feet (ft) were 2,900 and $2,880 \mathrm{mg} / \mathrm{L}$, respectively, and 2,900 and 2,850 $\mathrm{mg} / \mathrm{L}$ at a depth of $860 \mathrm{ft}$, respectively. Previous composite samples from the entire open interval (840-880 ft) during 1994-2001 had chloride concentrations that ranged from about 2,700 to $3,400 \mathrm{mg} / \mathrm{L}$.

At Skidaway Island, fluid conductivity (resistivity) logs and water samples were collected December 12, 2006, and December 4, 2007, from well 37P113 completed in the Lower Floridan aquifer, and December 13, 2006, and December 5, 2007, from well 37P114 completed in the Upper Floridan aquifer. In well 37P113, the fluid resistivity logs collected during 2006-2007 indicated no changes or breaches in the well casing, and the mean specific conductance in the open borehole increased from 6,011 to $6,942 \mu \mathrm{S} / \mathrm{cm}$ during the period.The chloride concentrations in samples collected at a depth of $900 \mathrm{ft}$ increased from 1,100 mg/L during 2006 to $1,590 \mathrm{mg} / \mathrm{L}$ during 2007 , which is consistent with the increase that began in 2005 ( $B$, facing page). In well 37P113, samples collected from a depth of 1,070 ft during the same period had chloride concentrations that decreased slightly from 4,800 to 4,740 mg/L, then leveling off from 2006-2008. Chloride concentrations in previous composite samples from

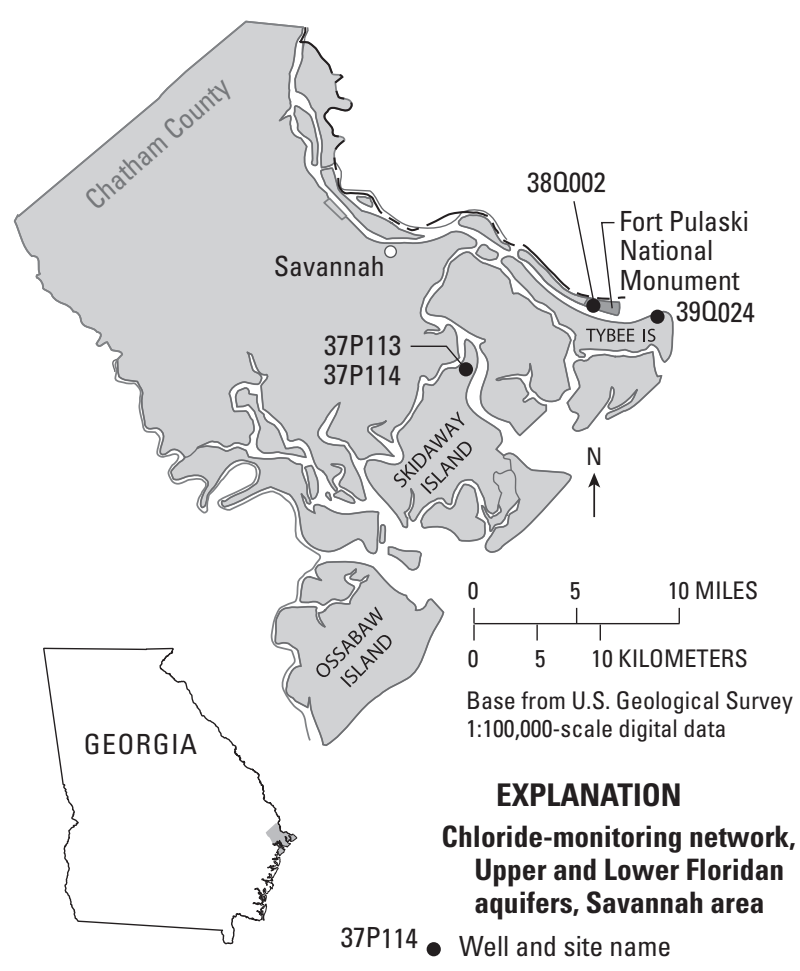

the entire open interval (700-1,100 ft) in well 37P113 during 1985-2001 ranged from about 300 to $1,000 \mathrm{mg} / \mathrm{L}$. Water in the Upper Floridan aquifer is fresh at the Skidaway Island site and chloride concentrations in samples from well 37P114 did not change during 2006-2007 ( $C$, facing page). The fluid resistivity logs collected during 2006-2007 indicated no changes or breaches in the well casing, and the mean specific conductance in the open borehole showed little change and ranged from 229 to $221 \mu \mathrm{S} / \mathrm{cm}$ during the period. During 2006-2007, chloride concentrations in samples collected at depths of 300 and $360 \mathrm{ft}$ ranged from 5.0 to $6.8 \mathrm{mg} / \mathrm{L}$. Previous composite samples from the entire open interval (262-400 ft) during 1984-2002 had chloride concentrations that ranged from 2 to $29 \mathrm{mg} / \mathrm{L}$.

At Fort Pulaski, fluid conductivity (resistivity) logs and water samples were collected December 11, 2006, and December 3, 2007, from well 38Q002 completed in the Upper Floridan aquifer ( $D$, facing page). The fluid resistivity logs collected during 2006-2007 indicated no changes or breaches in the well casing, and the mean specific conductance in the open borehole showed little change and ranged from 238 to $231 \mu \mathrm{S} / \mathrm{cm}$ during the period. During 2006-2007, chloride concentrations in samples collected at depths of 200 and $320 \mathrm{ft}$ ranged from 8.8 to $12 \mathrm{mg} / \mathrm{L}$.

\section{Reference}

Leeth, D.C., Peck, M.F., and Painter, J.A., 2007, Ground-water conditions and studies in Georgia, 2004-05: U.S. Geological Survey Scientific Investigations Report 2007-5017, 128 p.; Web-only publication available at http://pubs.usgs.gov/ sir/2007/5017/. 
A. Lower Floridan aquifer

Tybee Island, well 390024

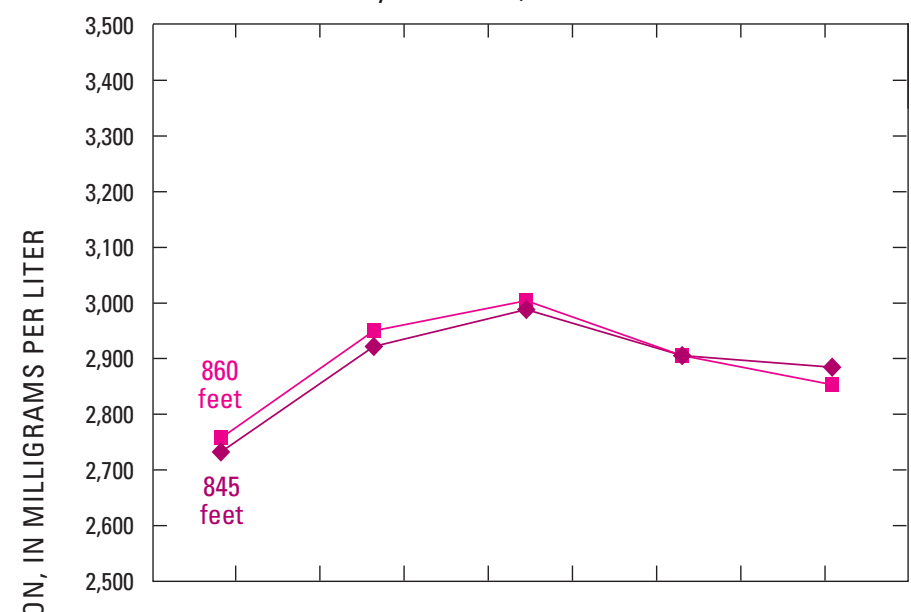

C. Upper Floridan aquifer

Skidaway Island, well 37P114

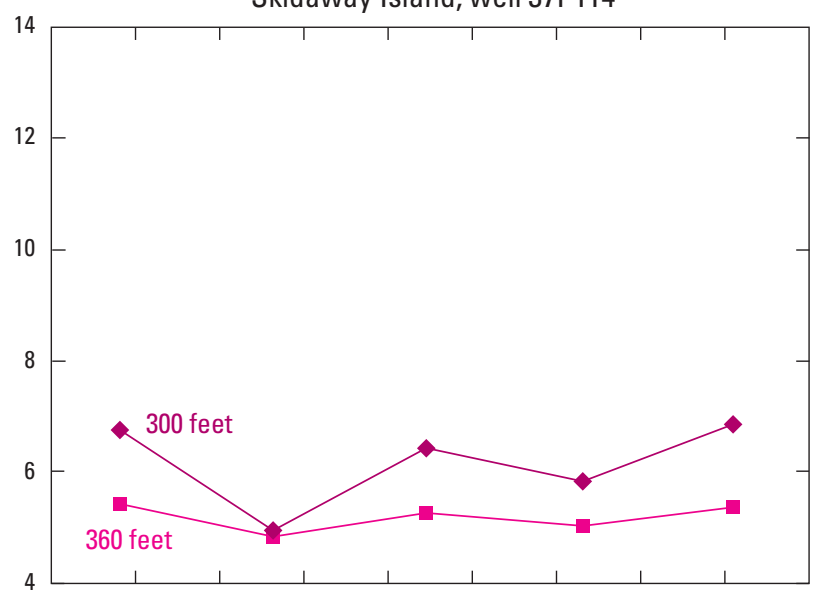

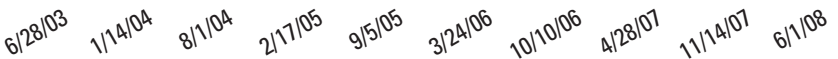

B. Lower Floridan aquifer

Skidaway Island, well 37P113

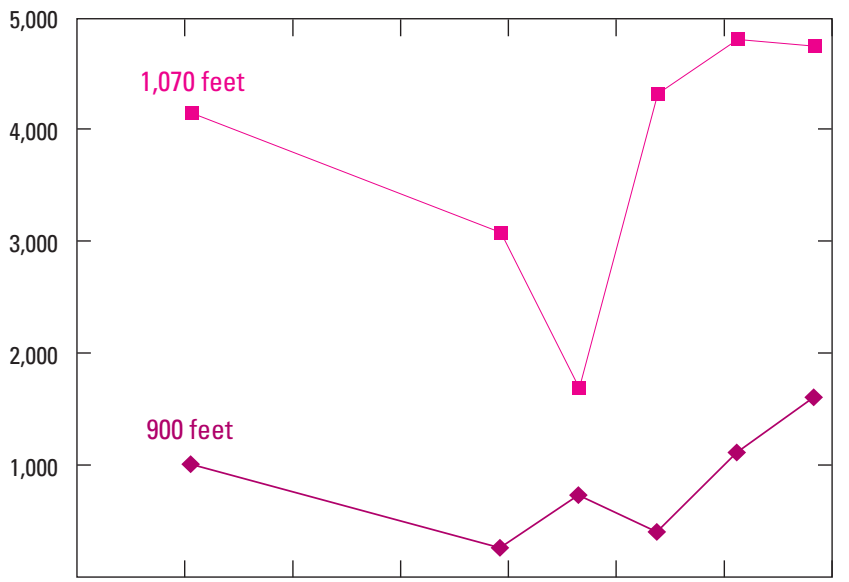

D. Upper Floridan aquifer

Fort Pulaski, well 380002

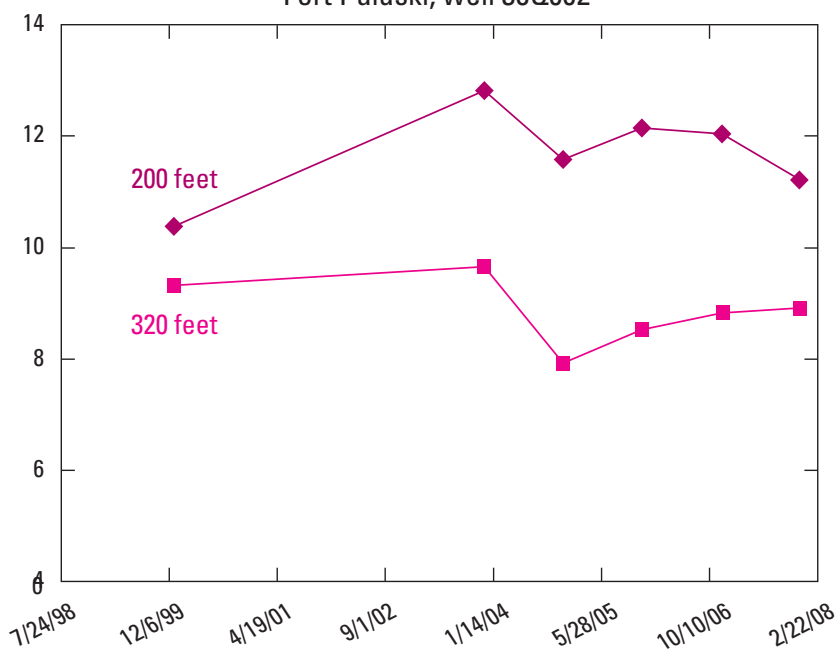

Chloride concentration in water from wells in the Upper and Lower Floridan aquifers in the Savannah area, Georgia, $2000-2007$.

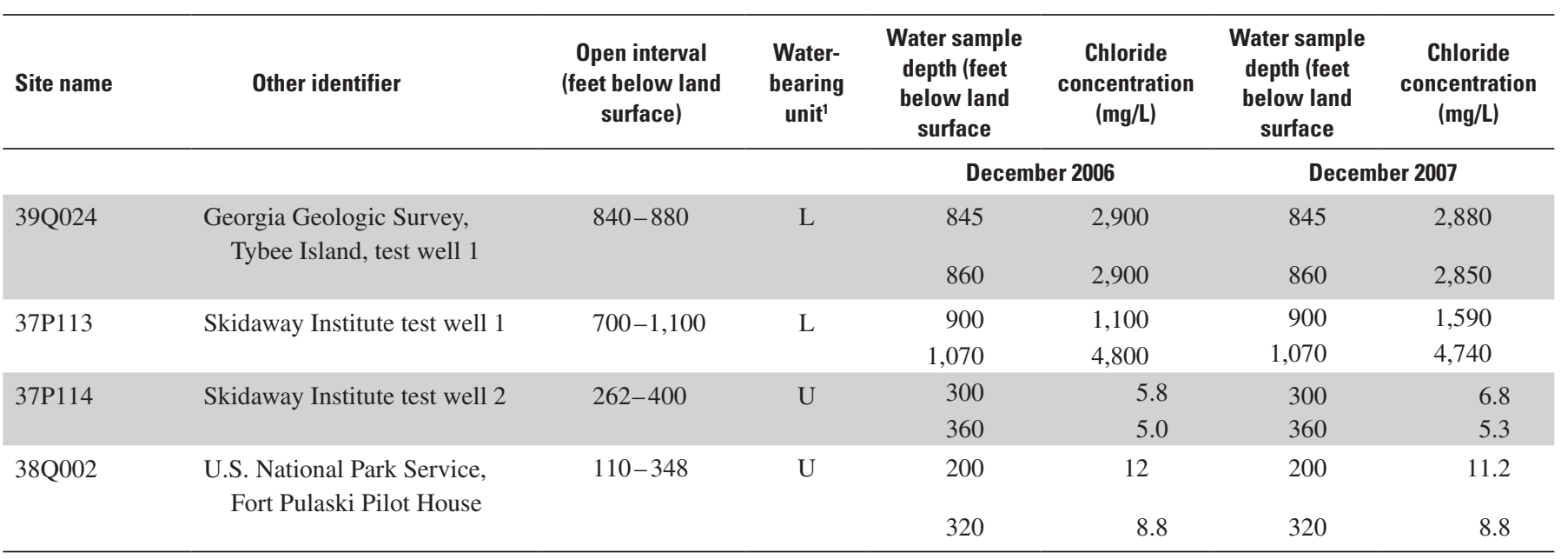

'L, Lower Floridan aquifer; $\mathrm{U}$, Upper Floridan aquifer; $\mathrm{mg} / \mathrm{L}$, milligrams per liter. 


\section{Ground-Water Quality in the Upper and Lower Floridan Aquifers}

\section{City of Brunswick Area}

Water supply in the Brunswick area primarily is obtained from wells completed in the Upper Floridan aquifer. Saltwater was first detected in the southernmost part of Brunswick during the late 1950s (Wait, 1965), and chloride concentrations have been monitored since that time. Saltwater was migrating upward from deep saline zones through breaches in confining units as a result of reduced pressure in the aquifer. By the 1960s, a plume of saltwater had migrated northward toward two major industrial pumping centers. During June 2005, the chloride concentration in water from the Upper Floridan aquifer was above the 250-milligrams per liter $(\mathrm{mg} / \mathrm{L})$ State and Federal secondary drinking-water standards (Georgia Environmental Protection Division, 1997; U.S. Environmental Protection Agency, 2000) in a 2-square-mile area and exceeded $2,250 \mathrm{mg} / \mathrm{L}$ in part of the area.

Graphs of chloride concentration in water samples from wells in the upper and lower water-bearing zones of the Upper Floridan aquifer are shown for wells in the southern Brunswick area (graphs for wells 34H393 and 34H403 below) and northern Brunswick area (graphs for wells $33 \mathrm{H} 127$ and 33H133 below). Chloride concentration in water from the Lower Floridan aquifer is shown for well 34H391 in the southern Brunswick area (graph below). More information on Brunswick area monitoring is available at http://ga.water.usgs.gov/projects/brunswick/.

Maps showing the concentration of dissolved chloride in the Upper Floridan aquifer at Brunswick were prepared for July 2006 (using data from 29 wells) and July and August 2007 (using data from 26 wells; chloride-concentration maps, facing page). The 2007 map is similar to the previously published map from 2005 (Leeth and others, 2007) and shows that areas of highest concentrations are near the two industrial pumping centers in the northern part of the city, and the original area of contamination in the southern part of the city.

During 2006-2007, chloride concentration within the plume area generally decreased. The greatest decrease in concentration was $200 \mathrm{mg} / \mathrm{L}$ at well $34 \mathrm{H} 434$, in the southern part of the plume. Only three wells had increases in chloride concentration that ranged from 4.0 to $20 \mathrm{mg} / \mathrm{L}$ during 2006-2007. These changes probably reflect shifts in local pumping patterns.

\section{References}

Cherry, G.S., and Clarke, J.S., 2008, Ground-water conditions and studies in the Brunswick-Glynn County area, Georgia, 2007: U.S. Geological Survey Open-File Report 2008-1297, 42 p.; Web-only publication available at http://pubs.usgs.gov/of/2008/1297/.

Georgia Environmental Protection Division, 1997, Secondary maximum contaminant levels for drinking water: Environmental Rule 391-3-5-19, revised October 1997: Official Code of Georgia Annotated Statutes, Statute 12-5-170 (Georgia Safe Drinking Water Act), variously paginated.

Leeth, D.C., Peck, M.F., and Painter, J.A., 2007, Ground-water conditions and studies in Georgia, 2004-2005: U.S. Geological Survey Scientific Investigations Report 2007-5017, 299 p.; Webonly publication available at http://pubs.usgs.gov/sir/2005/5065/.

U.S. Environmental Protection Agency, 2000, Maximum contaminant levels (Part 143, National Secondary Drinking Water Regulations): U.S. Code of Federal Regulations, Title 40, Parts 100-149, rev. July 1, 2000, p. 612-614.

Wait, R.L., 1965, Geology and occurrence of fresh and brackish ground water in Glynn County, Georgia: U.S. Geological Survey Water-Supply Paper 1613-E, 94 p.
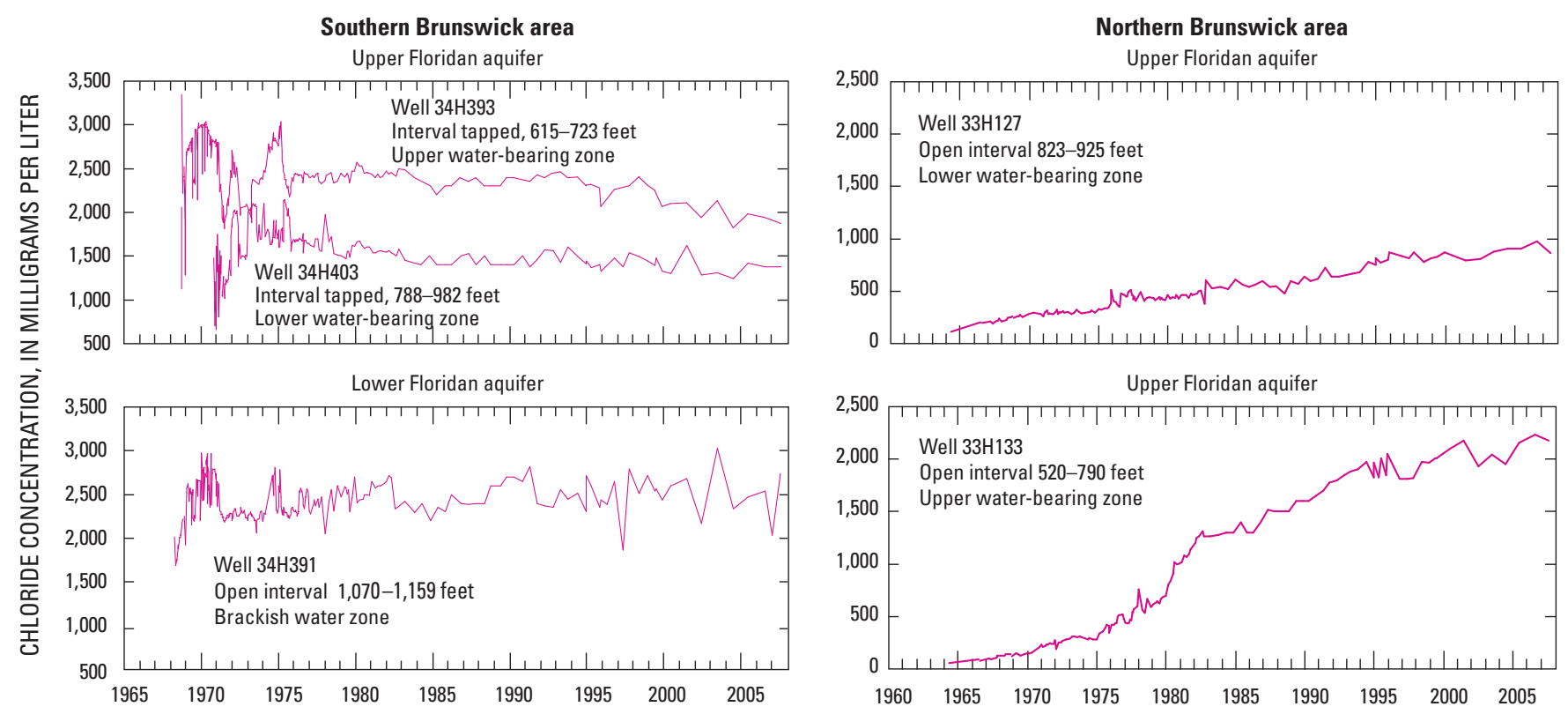


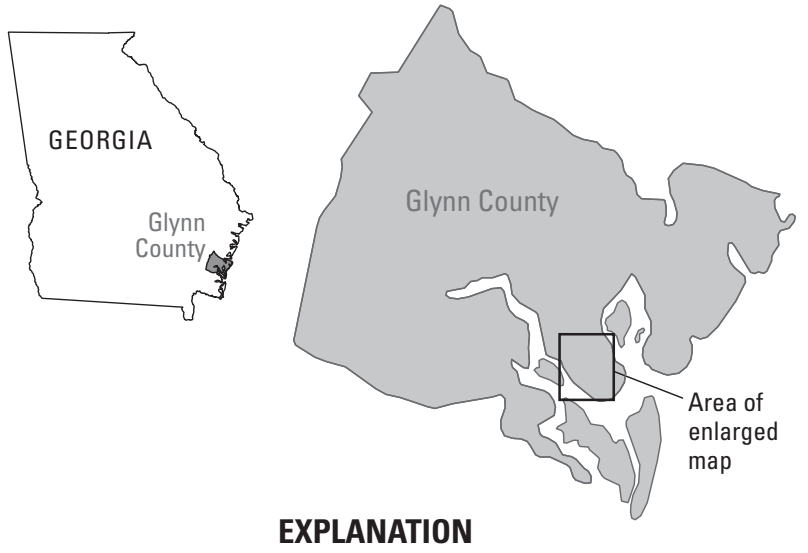

MAPS BELOW

Chloride concentration in water from upper water-bearing zone of Upper Floridan aquiferIn milligrams per liter

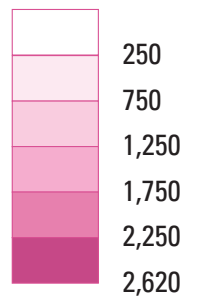

- Data point

\section{MAP AT RIGHT}

Change in chloride concentration in water from upper water-bearing zone of Upper Floridan aquifer, in milligrams per liter, and site name

$\Downarrow-200$ to $-50.01 \quad \uparrow 0.001$ to 15 $\downarrow-50$ to 0

-34H391 Well and site name$\mathrm{L}$, lower water-bearing zone of Upper Floridan aquifer; LFA, Lower Floridan aquifer
Chloride concentration, July 2006

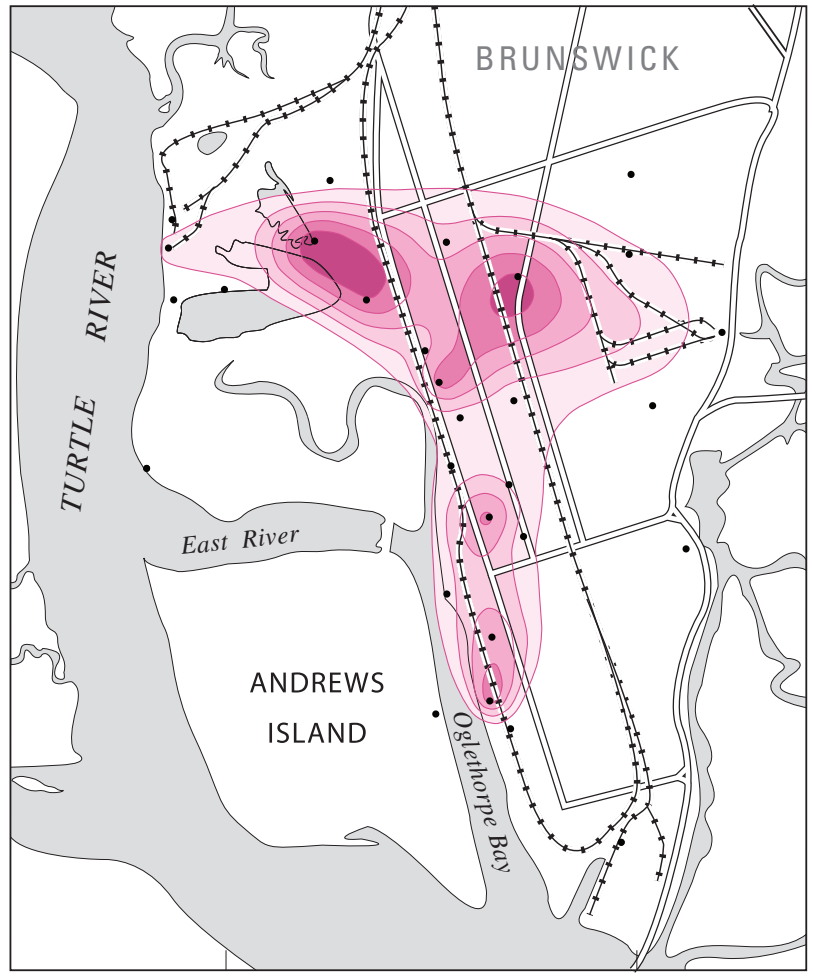

Change in chloride concentration from 2006 to 2007

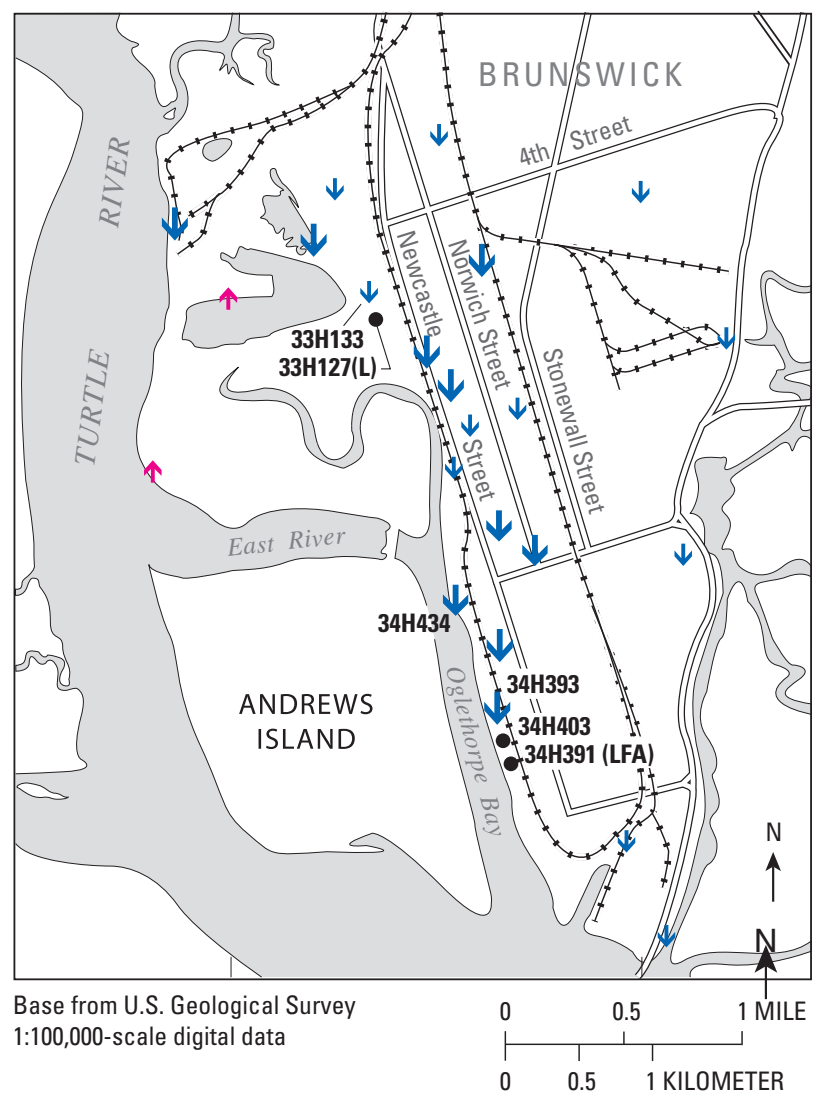

Chloride concentration, July-August 2007

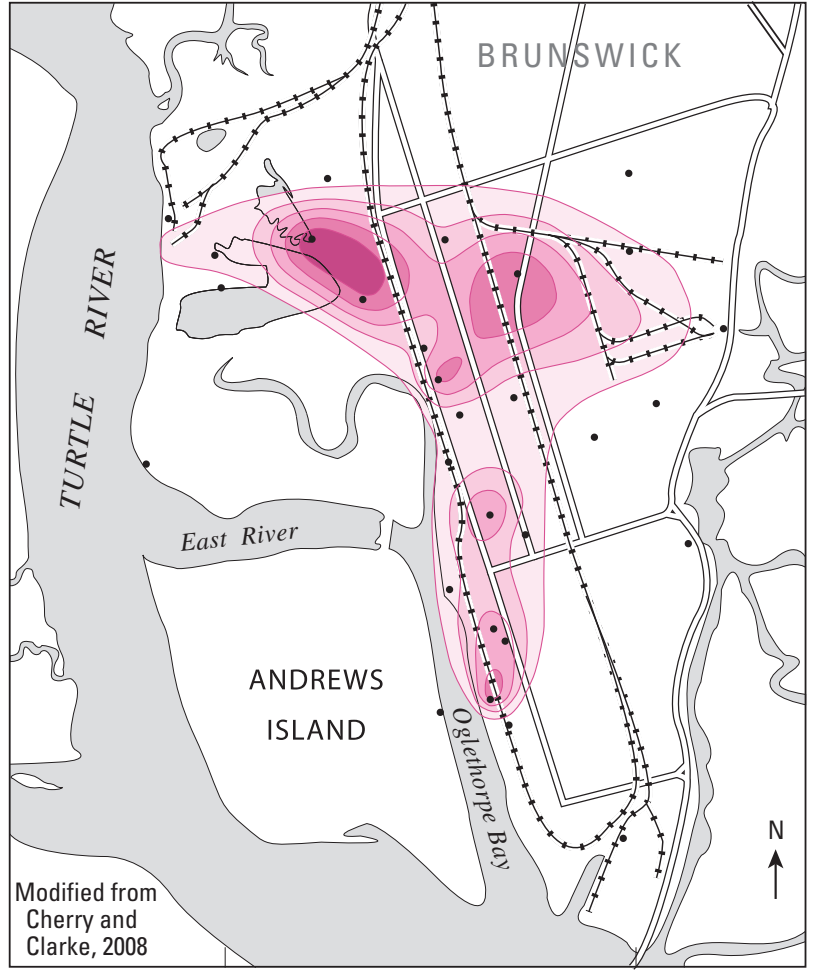




\section{Ground-Water Quality in the Upper and Lower Floridan Aquifers}

\section{Camden County Area}

In the Camden County area, chloride concentrations have been monitored periodically in the Upper Floridan aquifer from 1959 to 1993 and annually to semiannually from 1994 to present. In the Lower Floridan aquifer, chloride concentrations have been monitored from 2001 to present. During 2006-2007, the U.S. Geological Survey collected 32 water samples from eight wells in Camden County; six wells were completed in the Upper Floridan aquifer and two wells were completed in the Lower Floridan aquifer. These wells (table, below) are part of a network maintained for the St. Johns River Water Management District in Florida. During 2006-2007, the range of chloride concentrations in the Upper Floridan aquifer was from 29 to 45.3 milligrams per liter ( $\mathrm{mg} / \mathrm{L}$ ), which is within the background range of 20 to $40 \mathrm{mg} / \mathrm{L}$ for the area (Peck and others, 2005) and below the 250-mg/L drinking-water standard (Georgia Environmental Protection Division, 1997; U.S. Environmental Protection Agency, 2000).

Since the closure of the Durango Paper Mill October 2002, the chloride concentration in well 33D061 decreased from a high of $184 \mathrm{mg} / \mathrm{L}$ during May 2000 to $42.6 \mathrm{mg} / \mathrm{L}$ during September 2007. The decrease in concentration corresponds to a 22- to 26-foot water-level rise that occurred after the closure of the Durango Paper Mill (Peck and others, 2005). This rise reversed the downward hydraulic gradient near the well and caused upward movement of relatively fresh ground water, resulting in decreased chloride concentration in the well. During 2006-2007, chloride concentrations in the Lower Floridan aquifer were below the $250-\mathrm{mg} / \mathrm{L}$ drinking-water standard. Concentrations ranged from 29.5 to $30.8 \mathrm{mg} / \mathrm{L}$ in well 33D073 completed in the upper section of the Lower Floridan aquifer at 1,360-1,560 ft, and from 93.2 to $99.2 \mathrm{mg} / \mathrm{L}$ in well 33D074 completed in the lower section of the Lower Floridan aquifer at 1,840-2,004 ft (table, below).

\section{References}

Georgia Environmental Protection Division, 1997, Secondary maximum contaminant levels for drinking water: Environmental Rule 391-3-5-19, revised October 1997: Official Code of Georgia Annotated Statutes, Statute 12-5-170 (Georgia Safe Drinking Water Act), variously paginated.

Peck, M.F., McFadden, K.W., and Leeth, D.C., 2005, Effects of decreased ground-water withdrawal on ground-water levels and chloride concentrations in Camden County, Georgia, and ground-water levels in Nassau County, Florida, from September 2001 to May 2003: U.S. Geological Survey Scientific Investigations Report 2004-5295, 31 p.; Web-only publication available at $h t t p: / / p u b s . u s g s . g o v /$ sir/2004/5295/.

U.S. Environmental Protection Agency, 2000, Maximum contaminant levels (Part 143, National Secondary Drinking Water Regulations): U.S. Code of Federal Regulations, Title 40, Parts 100-149, rev. July 1, 2000, p. 612-614.

Chloride-monitoring network in the Floridan aquifer system, Camden County, Georgia

[UF, Upper Floridan aquifer; LF, Lower Floridan aquifer; - , no data]

\begin{tabular}{|c|c|c|c|c|c|c|c|}
\hline Site name & Other identifier & Aquifer & $\begin{array}{l}\text { Open interval } \\
\text { (feet below } \\
\text { land surface) }\end{array}$ & \multicolumn{4}{|c|}{ Chloride concentration (milligrams per liter) } \\
\hline 32E033 & Georgia Welcome Center & UF & $420-600$ & ${ }^{1} 29.0$ & ${ }^{1} 29.1$ & ${ }^{1} 30.5$ & ${ }^{1} 29.9$ \\
\hline 33D054 & St. Marys 2 & UF & $563-1,000$ & ${ }^{1} 30.5$ & ${ }^{1} 30.8$ & 30.7 & ${ }^{1} 29.4$ \\
\hline 33D061 & Gilman Paper Company 11 & UF & $550-1,090$ & ${ }^{1} 45.3$ & ${ }^{1} 43.4$ & ${ }^{1} 44.0$ & ${ }^{1} 42.6$ \\
\hline 33E053 & Kings Bay 2 & UF & $570-900$ & 134.1 & 135.3 & 133.5 & 134.0 \\
\hline 34E001 & $\begin{array}{l}\text { Cumberland Island Georgia } \\
\text { Geologic Survey test well } 1\end{array}$ & UF & $540-640$ & ${ }^{1} 31.1$ & ${ }^{1} 31.4$ & 131.0 & ${ }^{1} 30.6$ \\
\hline 33D073 & CSSI St. Marys test well 1 & $\mathrm{LF}$ & $1,360-1,500$ & 30.8 & 29.5 & 29.5 & - \\
\hline
\end{tabular}

'Bill Osborne, St. Johns River Water Management District, written commun., July 2008. 


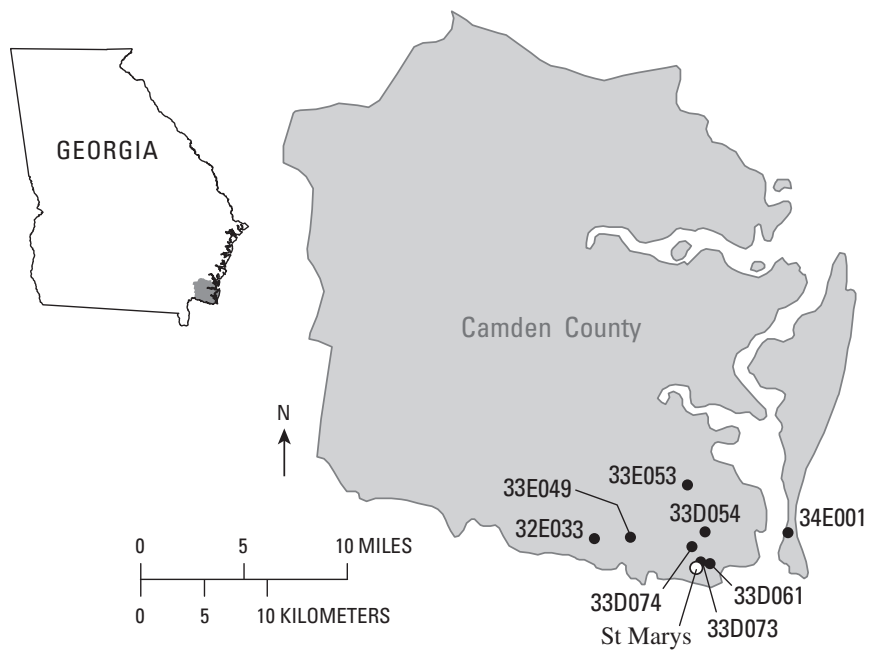

EXPLANATION

-34E001 Chloride-monitoring well and site name

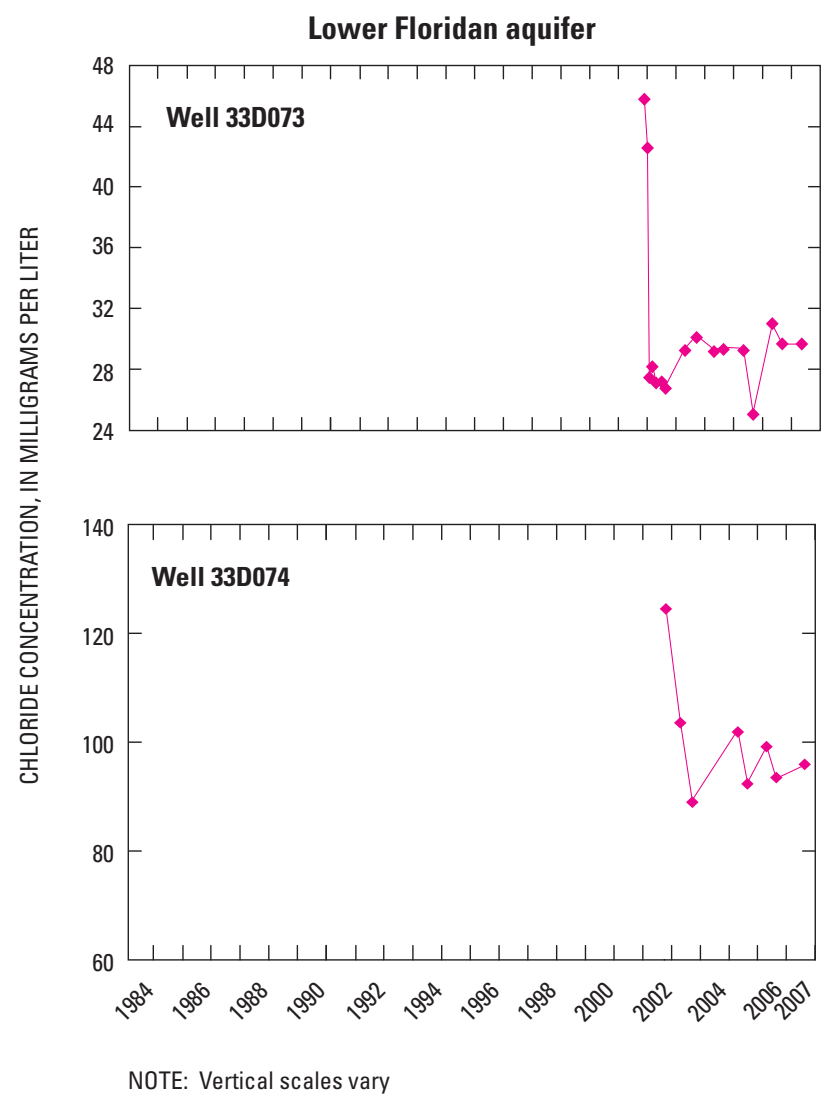

Upper Floridan aquifer
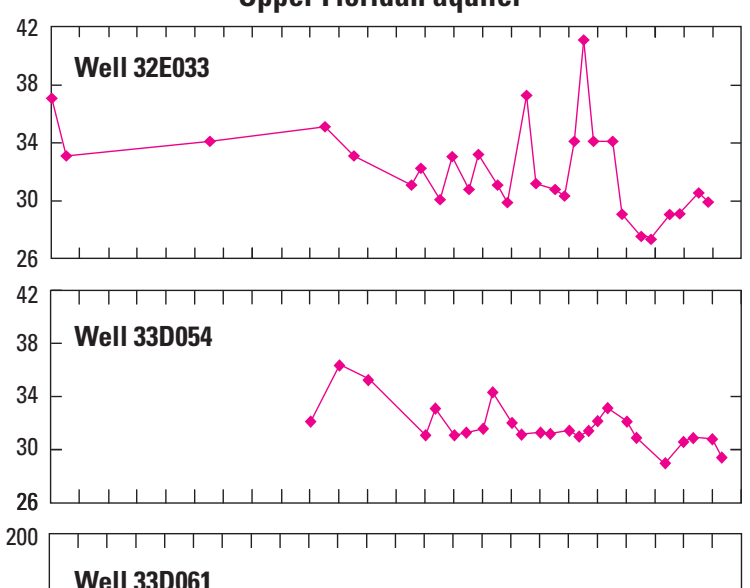

180

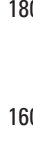

160

140

120
100

100
80

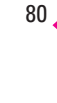

60
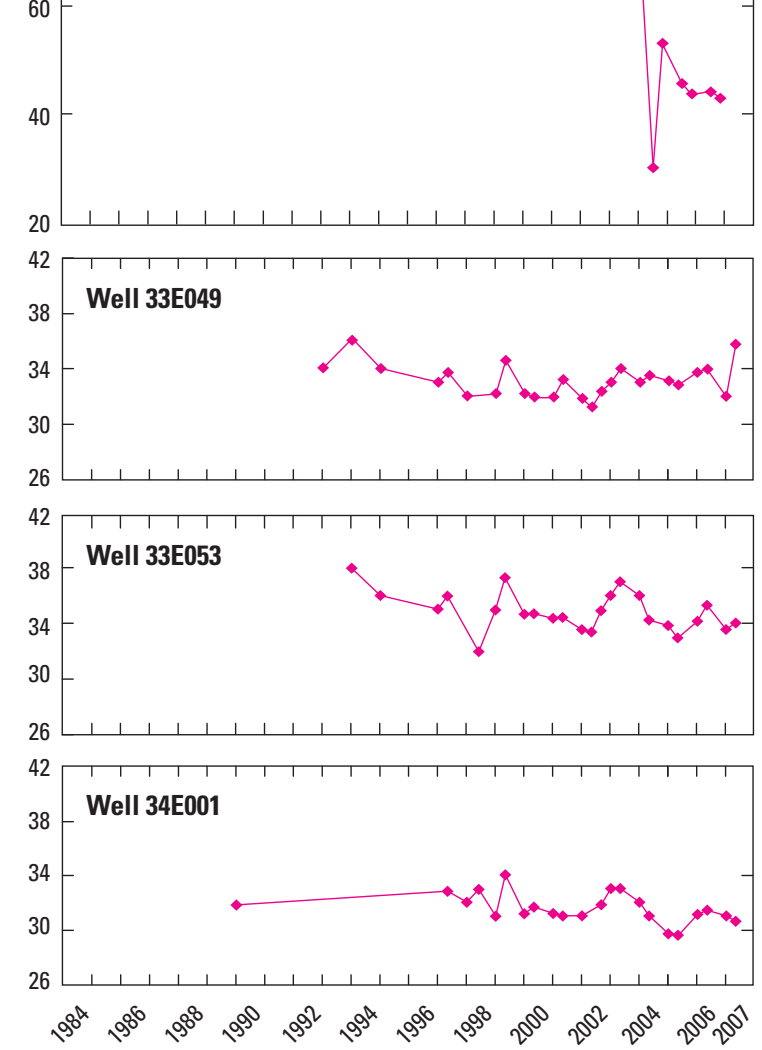



\section{Selected Ground-Water Studies in Georgia, 2006-2007}

The U.S. Geological Survey (USGS) — in cooperation with local, State, and other Federal agencies - conducted several studies in Georgia and adjacent states during 2006-2007 to better define the occurrence and quality of ground water and to monitor hydrologic conditions. Summaries of current USGS studies in Georgia are provided in the following sections and include information regarding

- Study title

- Study area location

- Study chief

- Cooperating agency or agencies
- Year study began

- Problem

- Objectives

- Progress and significant results

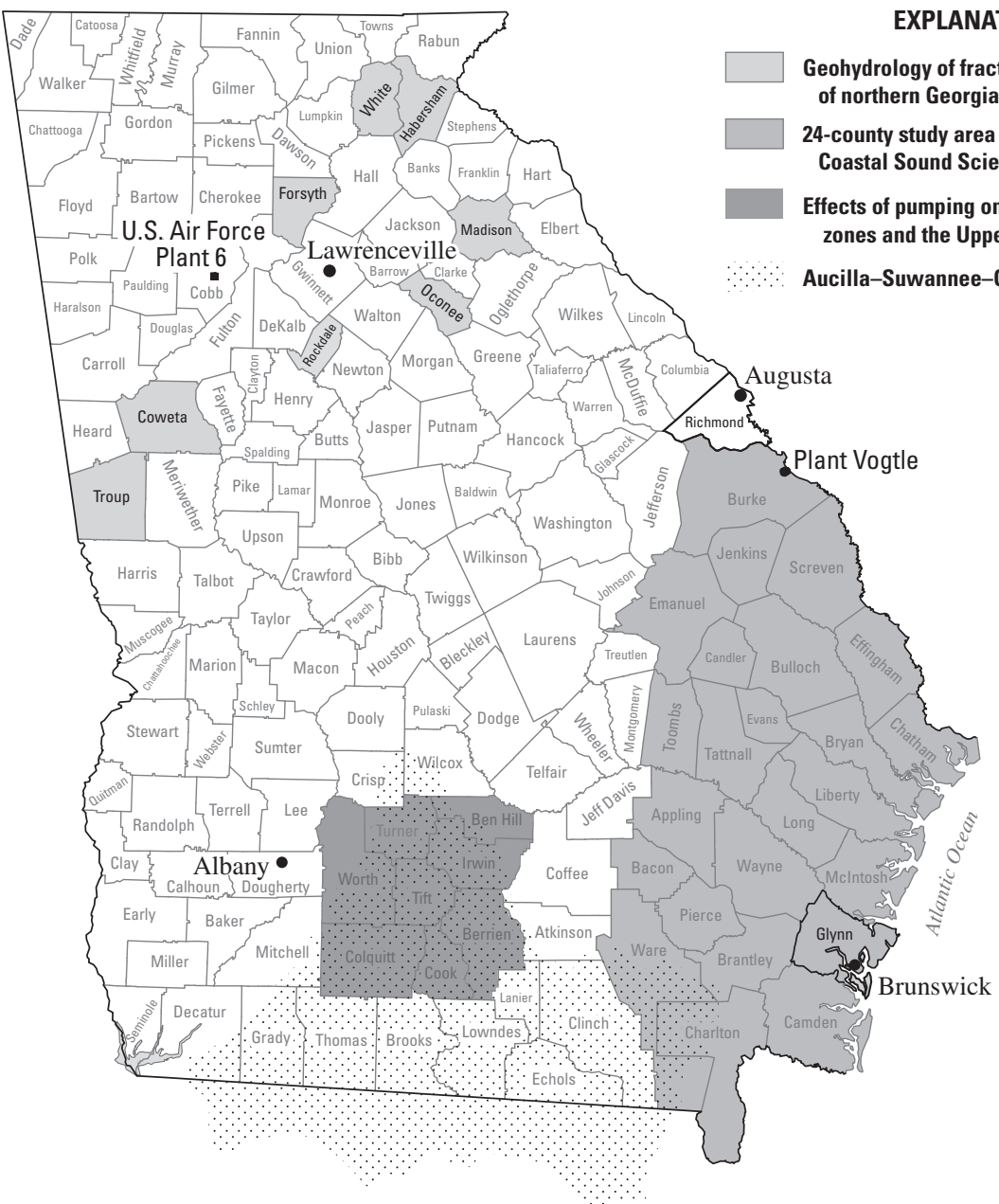




\section{Ground-Water Monitoring Program for the Augusta-Richmond County Area}

$\begin{array}{ll}\text { Study Chief } & \text { Lester J. Williams and Stephen J. Lawrence } \\ \text { Cooperator } & \text { Augusta Utilities Department } \\ \text { Year Started } & 2006\end{array}$

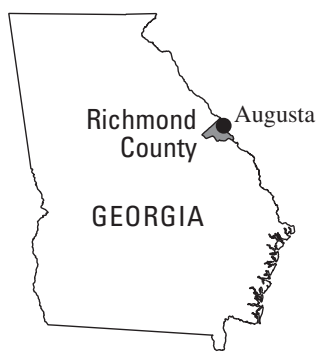

Progress and Significant Results, 2006-2007

- Installed continuous water-level recorder in well 30AA33 at Augusta Regional Airport.

- Obtained water-level measurements during January 2007 and constructed a potentiometric-surface map for the Dublin-Midville aquifer system (map on facing page).

- Completed a field inventory of new and existing wells to re-establish a ground-water monitoring network in the Augusta-Richmond County area.

- Published a report on the hydrogeologic conditions in the study area (Williams, 2007).

\section{Reference}

Williams, L.J., 2007, Hydrogeology and potentiometric surface of the Dublin and Midville aquifer systems in Richmond County, Georgia, January 2007: U.S. Geological Survey Scientific Investigations Map 2982, 1 sheet; Web-only publication available at http://pubs.usgs.gov/ $\operatorname{sim} / 2007 / 2982 /$.

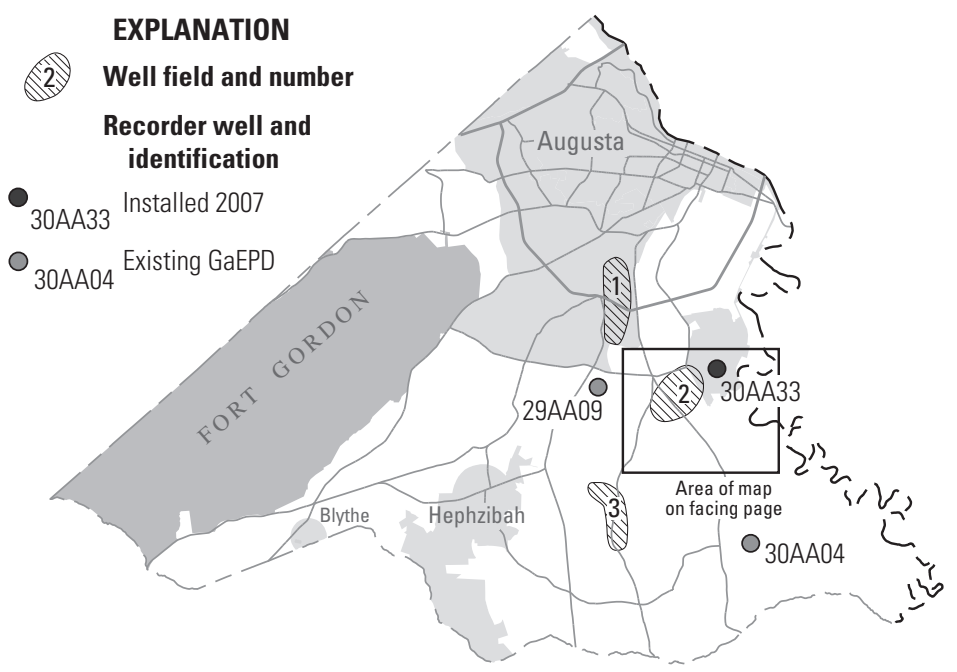

General area of the ground-water monitoring study showing the three municipal well fields and recorder wells in the Augusta-Richmond County area of Georgia. [GaEPD, Georgia Environmental Protection Division] 


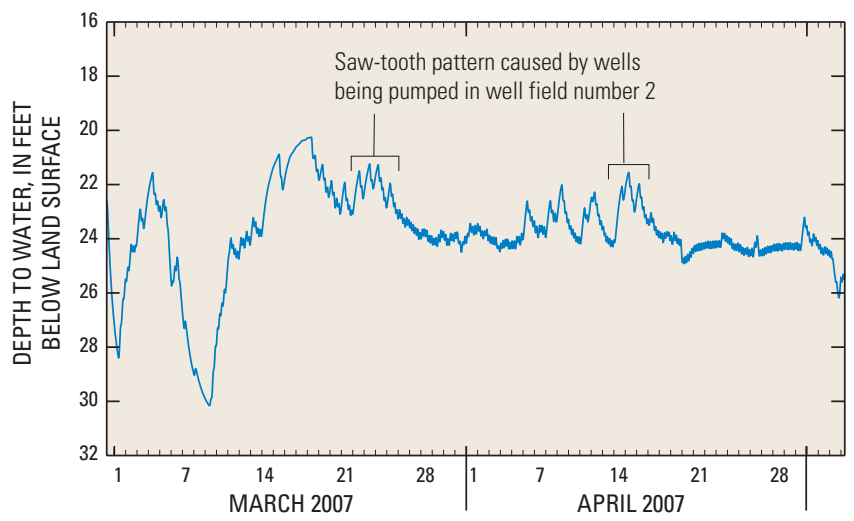

Continuous water-level measurements showing fluctuations in the depth to water at the recorder well (30AA33) east of well field number 2. Saw-tooth patterns are water-level fluctuations caused by nearby pumping wells in the well field.

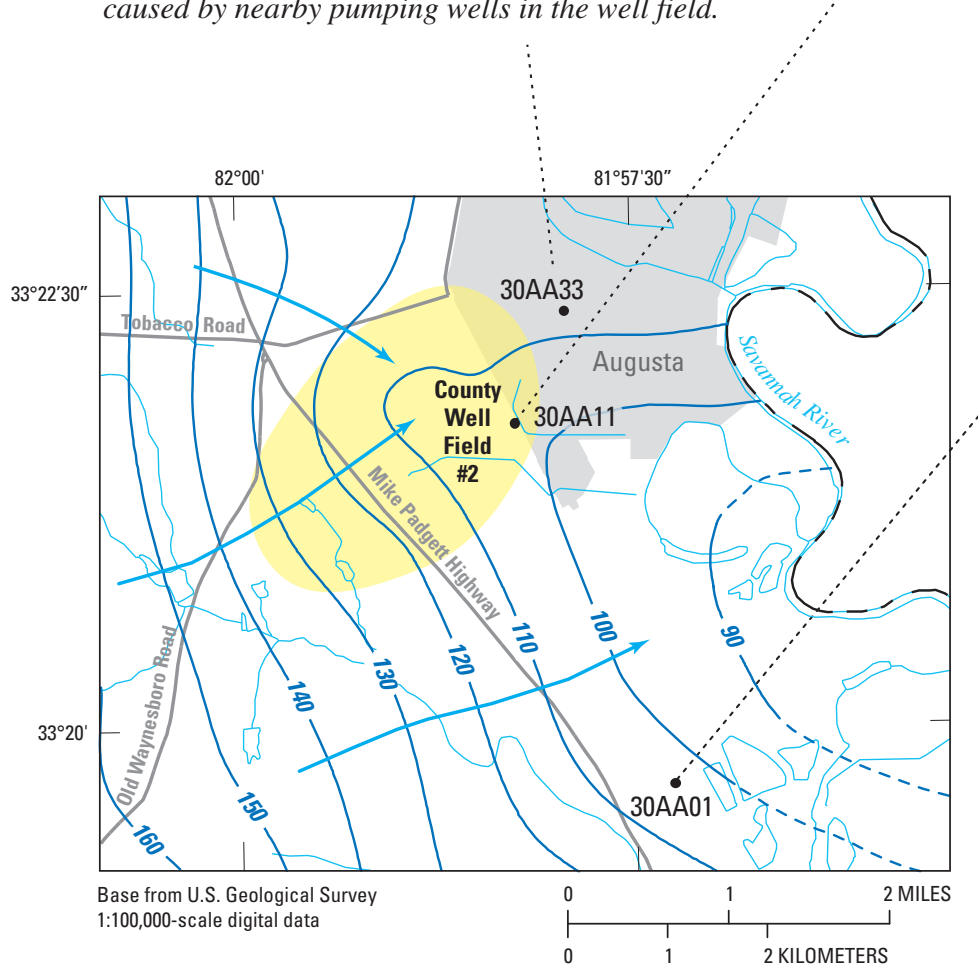

EXPLANATION

\section{Well field}

- 140 - - Potentiometric contour-Shows approximate altitude at which water level would have stood in tightly cased wells, January 2007. Dashed where inferred. Contour interval 10 feet. Datum is NGVD 29

\section{$\longrightarrow$ General direction of ground-water flow}

\section{AA33 - Well and identification}

Potentiometric surface and flow direction of ground water in and around Richmond County well field number 2 during January 2007. Flow direction typically is west to east toward the Savannah River (modified from Williams, 2007).

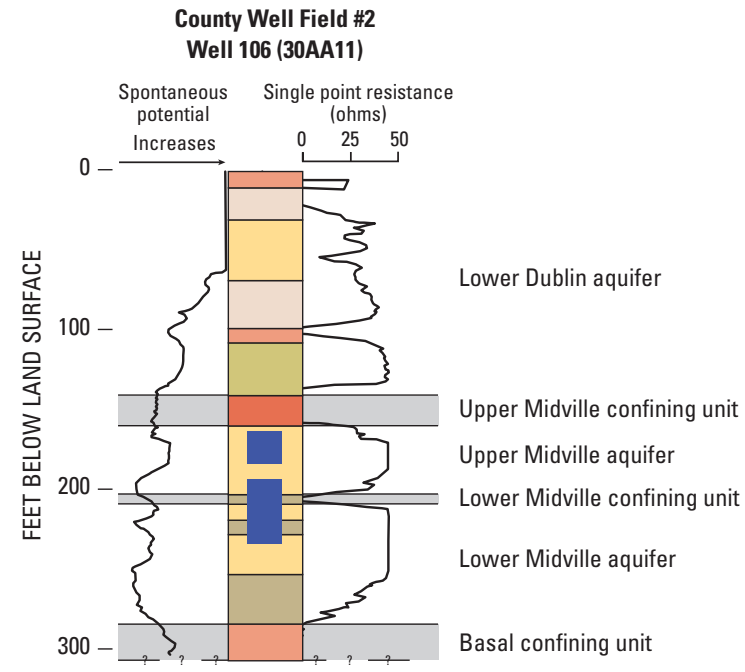

\section{EXPLANATION}

Lithology_-Taken from drillers' logs

$\begin{array}{ll}\square \text { Massive clay } & \square \text { Sand with clay layers } \\ \square \text { Sand and/or gravel } & \text { Red clay } \\ \square \text { Clayey sand } & \text { Mostly clay } \\ \square \text { Sandy clay } & \text { Rock layers } \\ \square \text { Sandy limestone } & \text { Basement rock } \\ \square \text { Clay with sand layers } & \text { Screen }\end{array}$

Hydrogeologic profiles showing lithology, confining layers, major aquifers, and well screen locations for Richmond County well 106 (top) and the well at the Continental Can facility (bottom) (modified from Williams, 2007). 


\section{Geohydrology of Fractured Crystalline Rock of Northern Georgia}

\author{
Study Chief Lester J. Williams \\ Cooperator Coweta County, Forsyth County, Oconee County, \\ Rockdale County, Troup County
}

Year Started 2007

\section{Problem}

Ground-water development and use in the fractured crystalline rocks of northern Georgia are critical to sustain population growth and economic development. Knowledge about groundwater movement, storage, vulnerability, quality, and connection with surface-water resources is limited because of the complexity of fractured-rock aquifers that underlie the region. A better understanding of the relation between the complex geology and ground-water resources in these areas is needed for water-resource managers and planners to develop effective management strategies and optimize available supply for future use.

\section{Objectives}

The primary objective is to evaluate the occurrence and quality of ground water in fractured crystalline rock of the Piedmont and Blue Ridge physiographic provinces of northern Georgia. Specific objectives are to

- Compile existing information on geology and wells.

- Conduct a field inventory of existing wells to verify construction, yield, and location.

- Collect borehole geophysical and flowmeter logs to determine depth, yield, and geologic and water-quality characteristics of water-bearing intervals.

- Evaluate geologic, well, and borehole geophysical data to identify geologic settings favorable for the development of sustainable water supplies.

- Establish a ground-water-level monitoring network for northern Georgia.

- Develop and maintain a comprehensive geohydrologic database of well and geophysical data.

This investigation provides information to help guide future ground-water development and water-management decisions for local communities while enhancing understanding of the hydrogeology of fractured rocks in the southern Piedmont and Blue Ridge physiographic provinces. Data from this study are entered into the USGS National Water Information System (NWIS) and are available on the Web at http://waterdata.usgs. gov/ga/nwis/inventory/.

\section{Progress and Significant Results, 2006-2007}

Coweta County-Developed plan of study to include well inventory and borehole geophysical logging in selected wells.

Forsyth County-Collected borehole geophysical logs and conducted borehole flowmeter traverse in two wells located

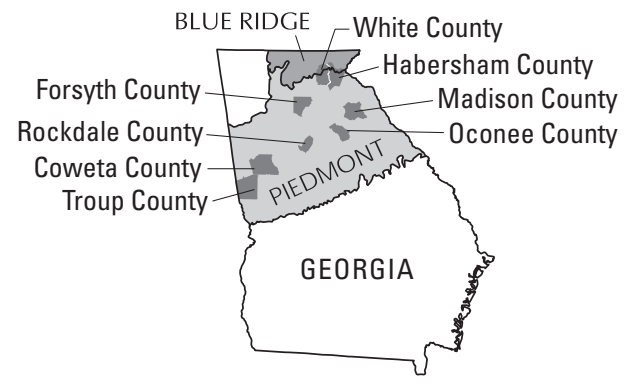

along the Chattahoochee River north of Littles Ferry Bridge. Developed plan of study for well-inventory program.

Oconee County - Collected borehole geophysical logs, grab water samples, and conducted borehole flowmeter traverse in two wells near the town of Watkinsville to evaluate causes of water-quality problems in the well water. In one well, dissolved carbon dioxide was being emitted; water in the other well was contaminated by iron bacteria.

Troup County-Completed compilation of data and field well inventory. Data for 138 wells were added to the existing 79-well NWIS database, which increased the total to 217 wells. Developed spatial hydrological data layers for wells and surficial geology. Began preparation of final report.

Rockdale County — Collected borehole geophysical logs in two test wells located adjacent to production wells in the Conyers area to determine structural orientations of fractures and bedrock foliation. This information was used to help assess the interconnection between test wells and production wells as a follow-up to aquifer testing conducted during 2005 (Williams and Cressler, 2007).

Other areas-In addition to the efforts in each of these counties, borehole geophysical logs were collected at several other sites in the Piedmont and Blue Ridge Provinces, including two wells in White County, one well in Habersham County, and one well in Madison County.

Outreach-Prepared a Fact Sheet describing how borehole geophysical logs can provide valuable information to evaluate ground-water resources in fractured crystalline rock (U.S. Geological Survey, 2007). The Fact Sheet describes the types of data collected and how these data are used to evaluate the water-bearing characteristics of fractured crystalline rock. See http://pubs.usgs.gov/fs/2007/3048/.

\section{References}

Williams, L.J., and Cressler, A.M., 2007, Regional effect of pumping ground water from deep fracture systems in the Conyers area, Rockdale County, Georgia, in Proceedings of the 2007 Georgia Water Resources Conference, March 27-29, 2007: Athens, Georgia, The University of Georgia; available on the Web at http://ga.water.usgs.gov/publications/gwrc07/pdf/ Williams_Cressler_GWRC07.pdf.

U.S. Geological Survey, 2007, Borehole geophysical logging of water-supply wells in the Piedmont, Blue Ridge, and Valley and Ridge, Georgia: U.S. Geological Survey Fact Sheet 2007-3048, 4 p.; Web-only publication available at http://pubs.usgs.gov/fs/2007/3048/. 


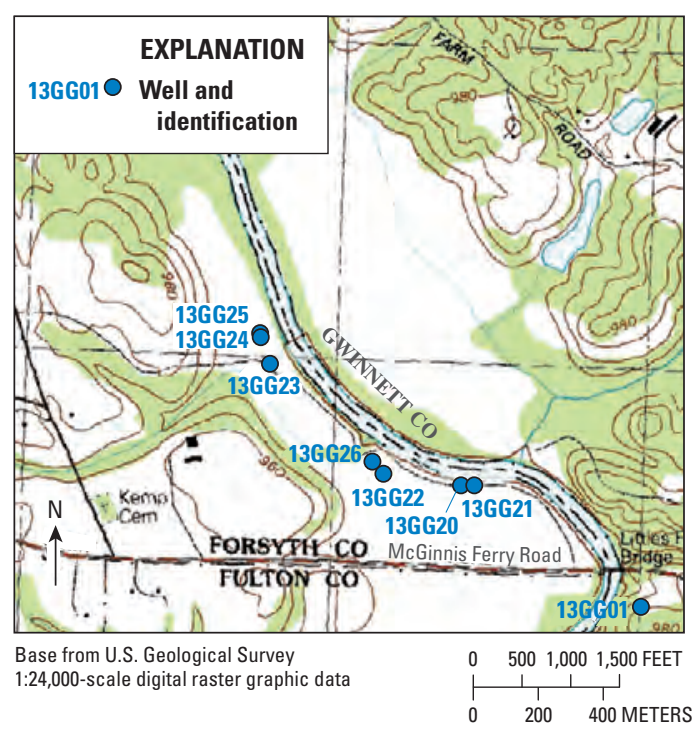

Borehole geophysical logs collected in two wells in Forsyth County, Georgia, demonstrate the relation between geology and productive water-bearing zones in the wells. The caliper log indicates areas of voids in the borehole, such as fractures. The optical televiewer log shows an image of the rock and structure of the borehole. A flowmeter traverse conducted in well $13 G G 20$ indicates water-bearing zones at yield. The 263-ft water-bearing zone is indicated by a larger well diameter on the caliper log and a dark void on the optical televiewer log. Structural measurements derived from borehole data indicate that water-bearing intervals are parallel to rock foliation at about a 23-degree dip angle. Projecting this dip angle from well $13 G G 20$ eastward $150 \mathrm{ft}$ indicates that the same water-bearing zone occurs at a depth of about $323 \mathrm{ft}$ in well $13 G G 21$. Interconnection of this zone between the two wells was also indicated by a 20-ft waterlevel response in well $13 G G 21$ during pumping of well $13 G G 20$.
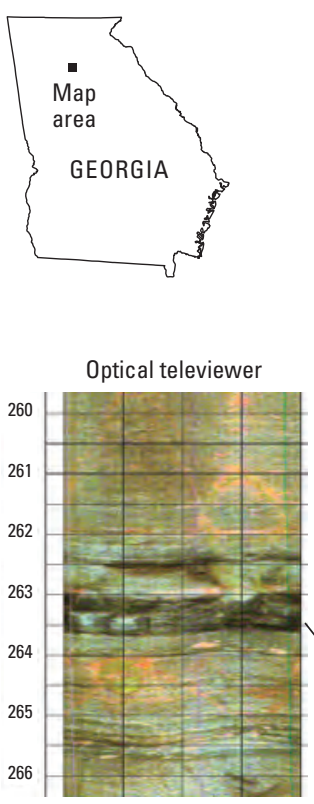
52, 143, and $263 \mathrm{feet}(\mathrm{ft})$, with the 263-ft zone producing about 68-percent of the total
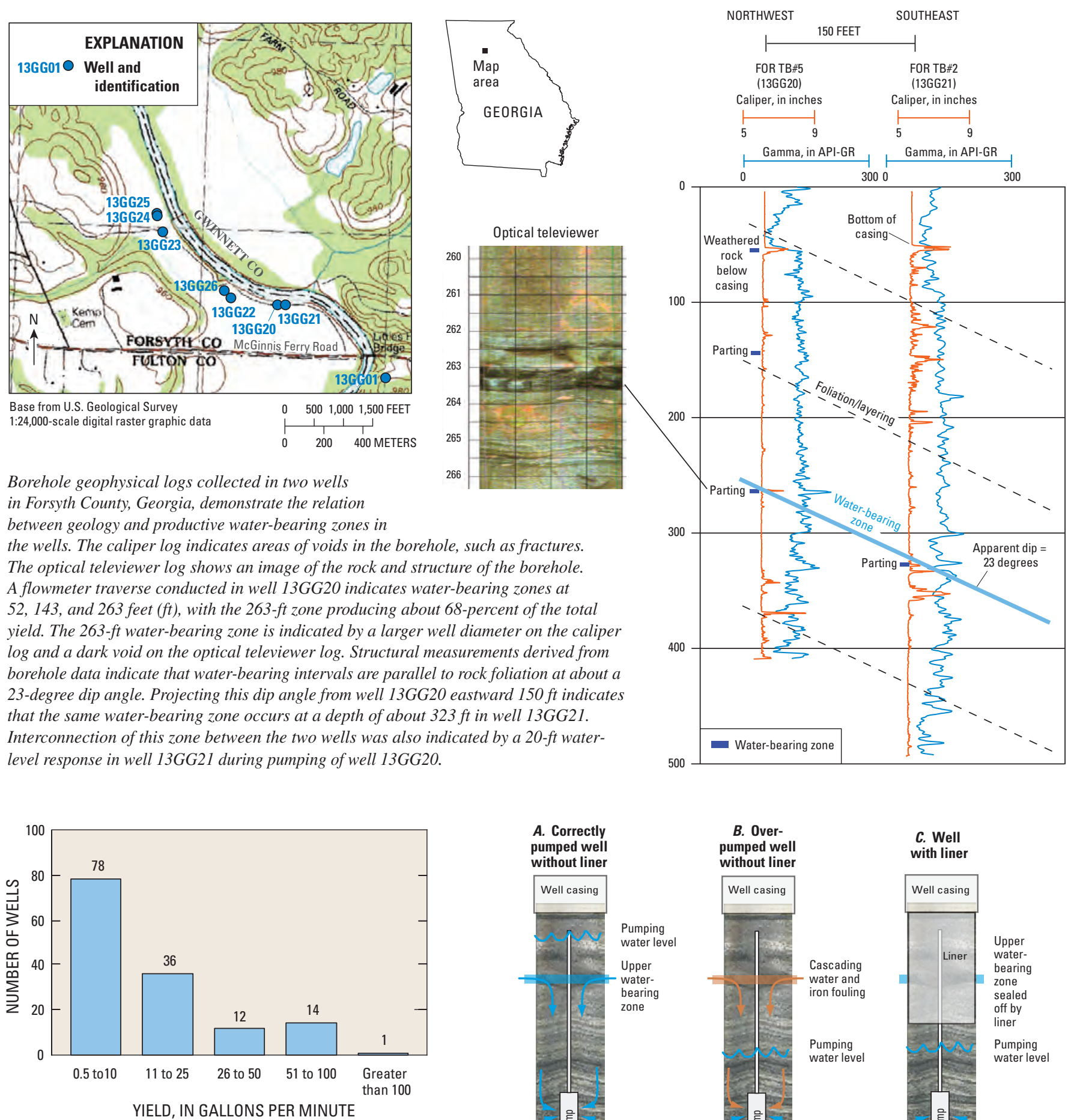

In Troup County, a well inventory conducted during 2007 indicated that well yields vary greatly across the county ranging from 0.5 to more than 150 gallons per minute ( $\mathrm{gal} / \mathrm{min})$. Of the wells inventoried, 97 had estimated yields from 0.5 to $25 \mathrm{gal} / \mathrm{min}, 13$ wells from 26 to $50 \mathrm{gal} / \mathrm{min}$, 14 wells from 51 to $100 \mathrm{gal} / \mathrm{min}$, and 1 well with an estimated yield of $150 \mathrm{gal} / \mathrm{min}$. There seems to be potential for development of high-yielding wells because 28 of the wells had yields of $26 \mathrm{gal} / \mathrm{min}$ or greater. The majority of the wells in the county probably were located based on convenience in relation to a home or business. A combination of detailed geologic mapping, well inventory, and geophysical logging can increase the probability of drilling a high-yielding well.
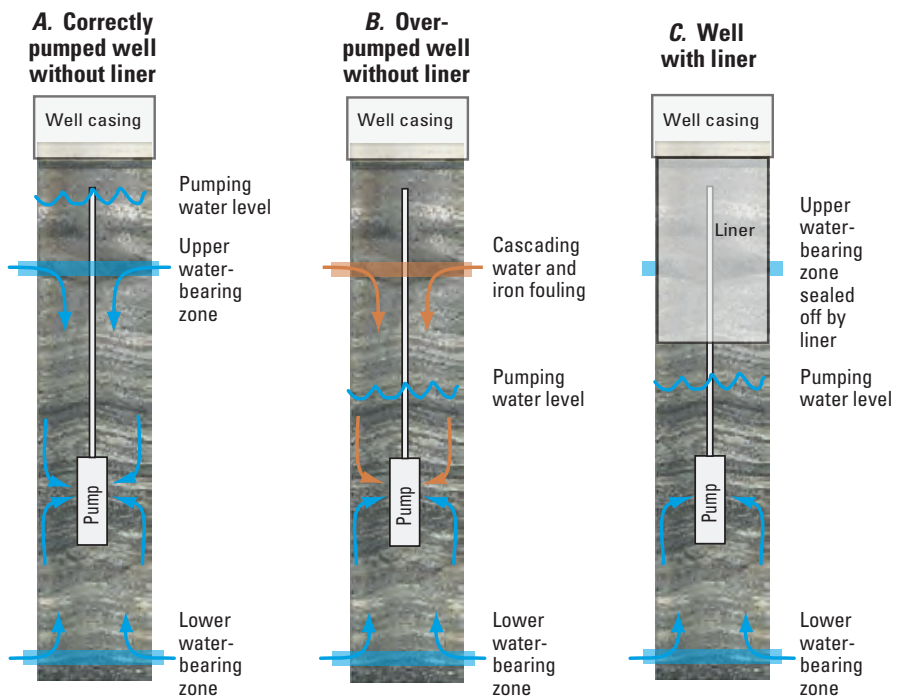

Borehole geophysical logs enable characterization of ground-water resources in fractured crystalline rock. These cross sections are excerpted from USGS Fact Sheet 2007-3048 and demonstrate how geophysical logs can be used to detect and prevent water-bearing zones from being exposed in the open portion of the borehole: (A) shows a correct pumping water level, (B) shows an over-pumped well without a liner, and $(C)$ shows a liner that seals off shallow-water zones. The Fact Sheet can be accessed on the Web at http://pubs.usgs.gov/fs/2007/3048/. 


\section{City of Albany Cooperative Water Program}

$\begin{array}{ll}\text { Study Chief } & \text { Debbie Warner Gordon } \\ \text { Cooperator } & \text { Albany Water, Gas, and Light Commission } \\ \text { Year Started } & 1977\end{array}$

\section{Problem}

Long-term heavy pumping from the Claiborne and Clayton aquifers and the Cretaceous aquifer system (includes the Providence aquifer), which underlie the Upper Floridan aquifer, has resulted in substantial water-level declines in these deep aquifers in the Albany area. To provide additional water supply and reduce the demand on the deep aquifers, the Albany Water, Gas, and Light Commission (WGL) developed a large well field southwest of Albany. The supply wells at this location primarily penetrate the Upper Floridan aquifer, a karstic unit that is the uppermost reliable source of water in the area. Because of local recharge to the aquifer, water quality may be affected by land-use practices. Nitrate levels exceeding the 10-milligrams per liter maximum contaminant level (U.S. Environmental Protection Agency, 2000) have been detected in some wells upgradient from the well field.

\section{Objectives}

- Monitor water-level fluctuations in the four deep aquifers in the Albany area and relate water-level trends to changes in climatic conditions and pumping patterns.

- Describe the ground-water flow and water quality of the Upper Floridan aquifer near the new well field in the southwestern Albany area.

\section{Progress and Significant Results, 2006-2007}

- Continued operation of the 14-well continuous groundwater-level monitoring network in the surficial, Upper Floridan, Claiborne, Clayton, and Providence aquifers.

- Continued ground-water-quality monitoring program. Water samples were collected and analyzed for cations, anions, and nutrients during November 14-16, 2006 (14 wells), and October 15-18, 2007 (12 wells).

- Constructed potentiometric-surface maps for the Upper Floridan aquifer near the well field based on measurements from 64 wells during October 16-24, 2006, and 60 wells during October 23-25, 2007. Both maps indicate that water generally flows from northwest to southeast near the well field. Although water levels during 2006 and 2007 generally were lower than during 2005, the well-field pumping did not result in the formation of a cone of depression surrounding the well field.

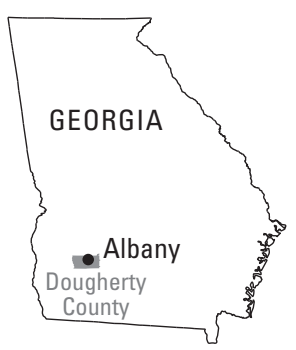

- Published "Potentiometric surface of the Upper Floridan aquifer in the southwestern Albany area, Georgia, 19982005, based on revised land-surface altitudes" (Gordon, 2006). The enhanced land-surface accuracy improved delineation of ground-water flow in the area.

- Continued to map sinkholes at the well field. No new sinkholes formed during 2006; however, during 2007, 12 new sinkholes developed.

- Continued to develop ground-water flow model for the well-field area. A variety of changes were made to the model design, including layering and boundary conditions. An extended abstract and poster presentation describing model development and preliminary results were prepared for the 2007 Georgia Water Resources Conference in Athens, March 27-29, 2007 (Gordon and Payne, 2007).

\section{References}

Barber, N.L., 1997, Potentiometric surfaces (fall 1994) and water-level fluctuations and trends in the Clayton and Claiborne aquifers in southwestern Georgia: Georgia Geologic Survey Hydrologic Atlas 21, 1 pl.

Clarke, J.S., Faye, R.E., and Brooks, Rebekah, 1984, Hydrogeology of the Clayton aquifer of southwest Georgia: Georgia Geologic Survey Hydrologic Atlas 13, 6 pls.

Gordon, D.W., 2006, Potentiometric surface of the Upper Floridan aquifer in the southwestern Albany area, Georgia, 1998-2005, based on revised land-surface altitudes, in Ground-water conditions and studies in Georgia, 2004-2005: U.S. Geological Survey Scientific Investigations Report 2007-5017, p 82-92, CD-ROM; also available online at http://pubs.usgs.gov/sir/2007/5017/.

Gordon, D.W., and Payne, D.F., 2007, Simulation of groundwater flow and nitrate transport in the Upper Floridan aquifer in the southwestern Albany area, Georgia, in Proceedings of the 2007 Georgia Water Resources Conference, March 27-29, 2007: Athens, Georgia, The University of Georgia, available on the Web at http://ga.water.usgs.gov/ publications/gwrc07/pdf/Gordon_GWRC07.pdf.

U.S. Environmental Protection Agency, 2000, Maximum contaminant levels (Part 143, National Secondary Drinking Water Regulations): U.S. Code of Federal Regulations, Title 40, Parts 100-149, rev. as of July 1, 2000, p. 612-614. 


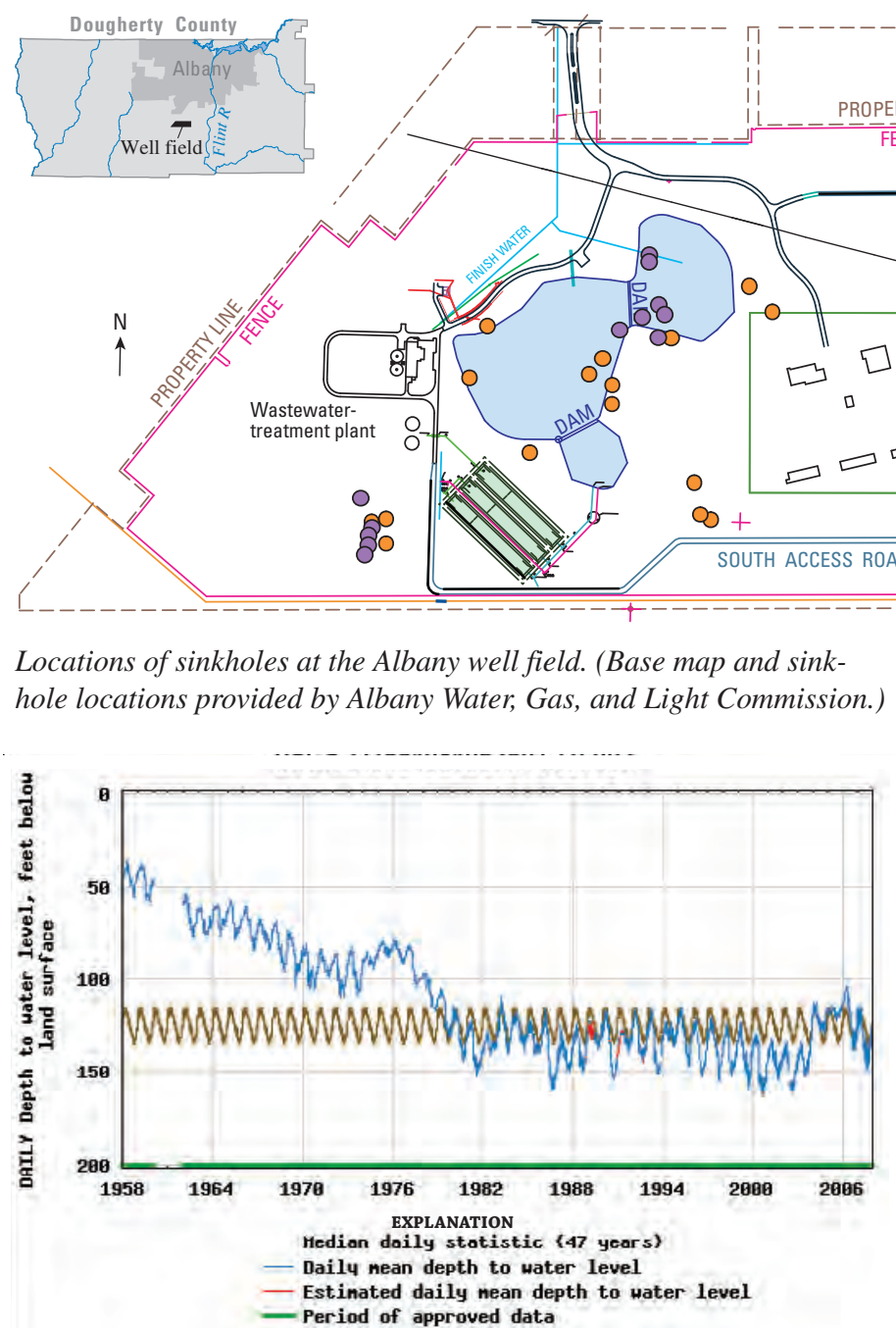

In the Albany area, water level in the Clayton aquifer declined from 1957 to the mid-1970s, as pumping by the city of Albany increased. The rate of decline increased from 1977 to 1981 as seasonal irrigation pumping increased (Clarke and others, 1984). Since 1981, water levels have stabilized because the Georgia Environmental Protection Division (GaEPD) imposed restrictions on pumping by the city of Albany, and the city instituted a management strategy using water levels to determine which wells to pump (Barber, 1997). During 1992, the GaEPD placed a moratorium on new withdrawals from the Clayton aquifer. Despite these measures, drought conditions during 1998-2002 resulted in increased withdrawals by permitted water users, and a record-low water level was measured on September 3, 2000.

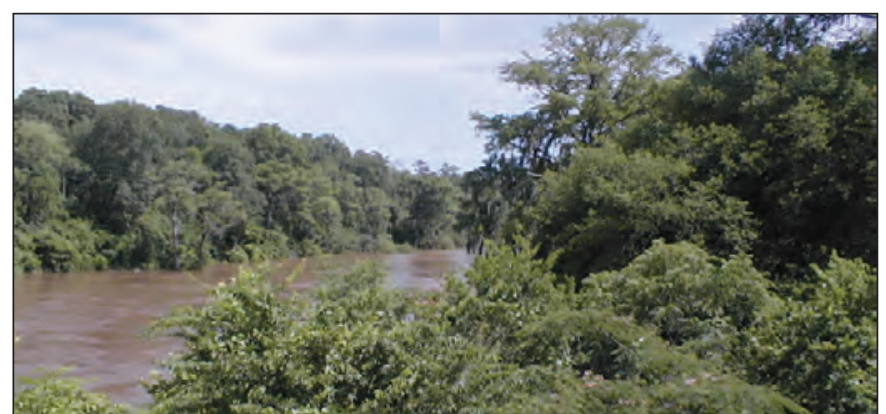

Flint River in Albany, Georgia. Photo by Debbie Warner Gordon.
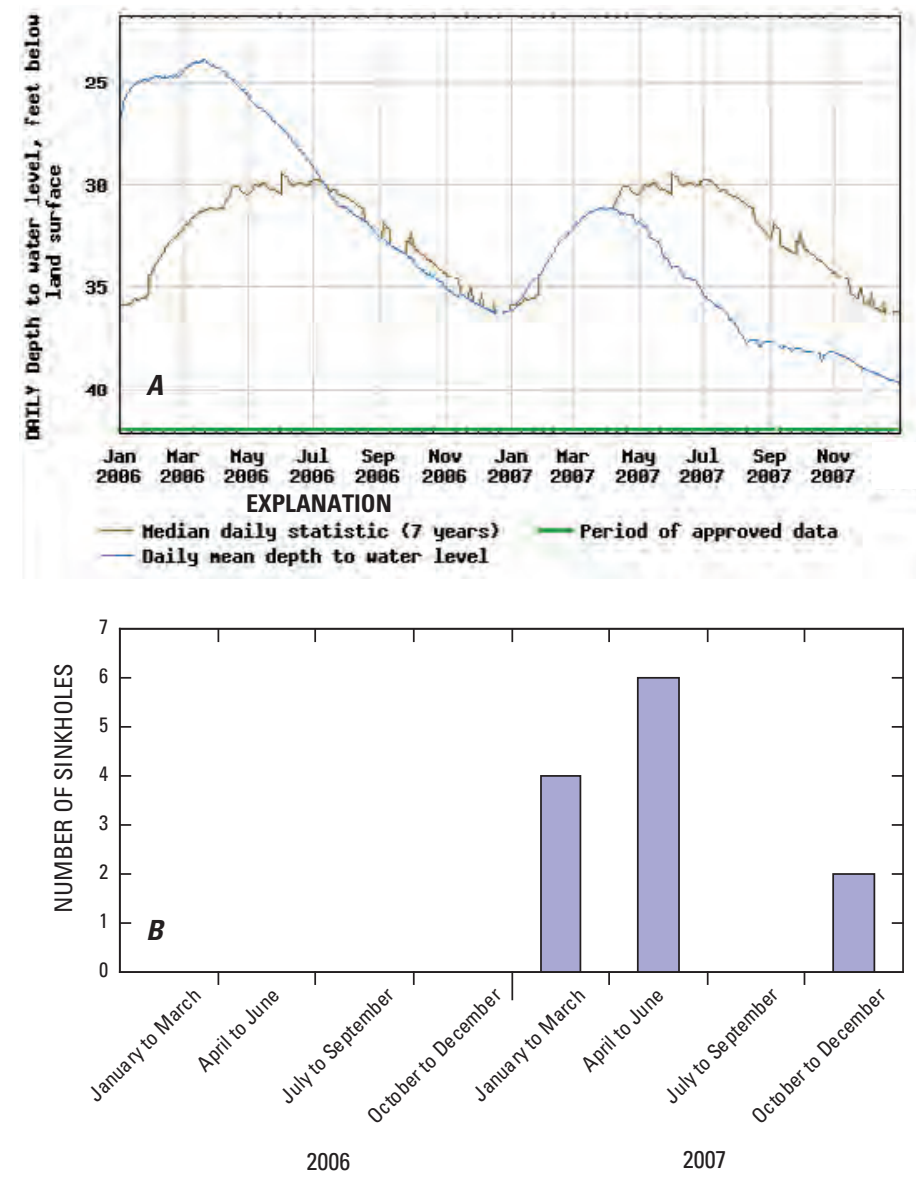

(A) Water level in the Upper Floridan aquifer near the Albany well field was above the median daily value from January to July 2006, near median levels through July 2007, and below median levels through the end of 2007. (B) Twelve sinkholes formed in the well field during 2007; these sinkholes may have developed because of low water levels. 


\section{City of Brunswick and Glynn County Cooperative Water Program}

\author{
Study Chief Gregory S. Cherry \\ Cooperator City of Brunswick \\ Glynn County \\ Jekyll Island Authority \\ Year Started 1959
}

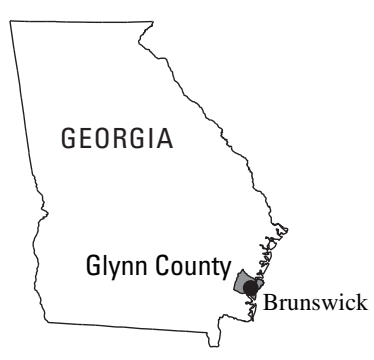

- For July 2006, based on analyses of chloride concentrations in samples collected from 71 wells.

- For July and August 2007, based on analyses of chloride concentrations in samples collected from 76 wells.

- Test wells that were completed in the surficial, Upper and Lower Floridan, and lower Brunswick aquifers in Glynn County and at a well-cluster site on St. Simons Island were incorporated into the GaEPD statewide network.

- The regional MODFLOW model of coastal Georgia and adjacent parts of Florida and South Carolina (Payne and others, 2005) was refined with higher resolution near Brunswick to simulate hydraulic gradients near pumping centers and help evaluate additional pumping in the Upper Floridan aquifer while containing the saltwater plume.

- Real-time monitoring systems were installed in wells completed in the upper and/or lower water-bearing zones of the Upper Floridan aquifer that surround the area of chloride contamination with the following continuous data collected:

-Water levels at Southside Baptist Church (wells 34H504 and 34H505), Perry Park (well 34H514), and GeorgiaPacific Cellulose (wells 33H324 and 33H325).

- Specific conductance at Southside Baptist Church (well 34H505), Perry Park (well 34H514; hydrograph, facing page) and Georgia-Pacific Cellulose (well 33H325).

- Information from the real-time ground-water-monitoring sites can be accessed at http://ga.water.usgs.gov/projects/ projectcoastalgwquality.html and http://waterdata.usgs.gov/ ga/nwis/current/?type $=g w \& g r o u p \_k e y=$ county_cd.

\section{References}

Georgia Environmental Protection Division, 1997, Secondary maximum contaminant levels for drinking water: Environmental Rule 391-3-5-19, revised October 1997: Official Code of Georgia Annotated Statutes, Statute 12-5-170 (Georgia Safe Drinking Water Act), variously paginated.

Payne, D.F., Rumman M.A., and Clarke J.S., 2005, Simulation of ground-water flow in coastal Georgia and adjacent parts of South Carolina and Florida-Predevelopment, 1980, and 2000: U.S. Geological Survey Scientific Investigations Report 2005-5089, 91 p.; Web-only publication available at http://pubs.usgs.gov/sir/2005/5089/.

U.S. Environmental Protection Agency, 2000, Maximum contaminant levels (Part 143, National Secondary Drinking Water Regulations): U.S. Code of Federal Regulations, Title 40, Parts 100-149, rev. July 1, 2000, p. 612-614. 

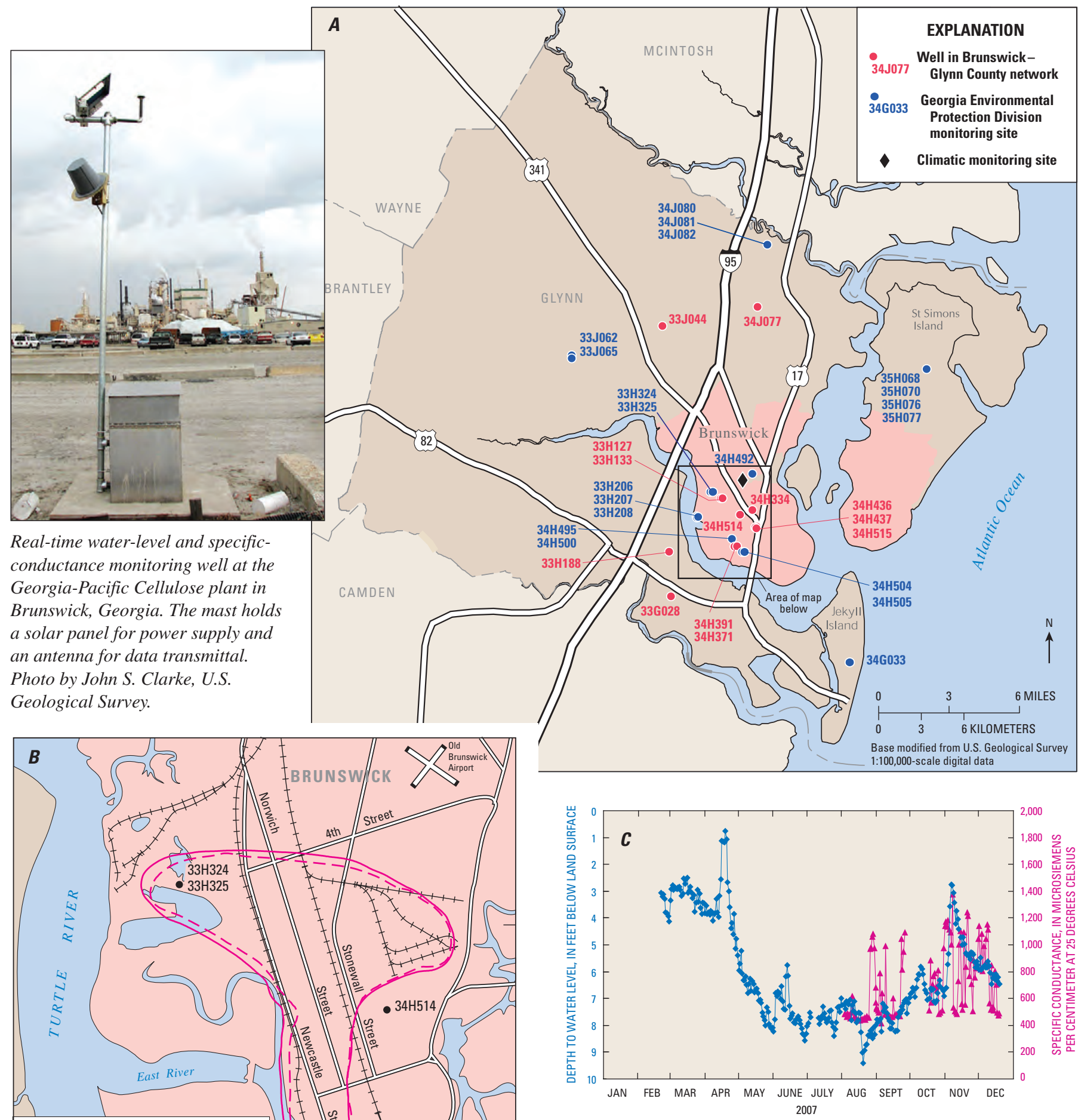

(A) Locations of study area and continuous ground-waterlevel monitoring network for the Brunswick-Glynn County area, Georgia; (B) positions of June 2001 and June 2005 chloride plumes in Upper Floridan aquifer; and locations of real-time monitoring wells; and $(C)$ daily mean groundwater levels and periodic specific conductance in the Upper Floridan aquifer at well 34 H514 during 2007. Groundwater-level data help in monitoring effects of pumping on flow directions, and real-time specific conductance data (a surrogate for chloride) provide information to track

the current position of chloride contamination.

Base modified from U.S. Geological Survey 1:24,000-scale digital data

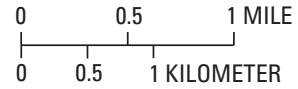




\section{Georgia Coastal Sound Science Initiative}

$\begin{array}{cl}\text { Study Chief } & \text { Dorothy F. Payne } \\ \text { Cooperator } & \begin{array}{c}\text { Georgia Department of Natural Resources } \\ \text { Environmental Protection Division }\end{array}\end{array}$

Year Started 2000

\section{Problem}

Pumping from the Upper Floridan aquifer has resulted in substantial water-level decline and saltwater intrusion at the northern end of Hilton Head Island, South Carolina, and at Brunswick, Georgia. This saltwater contamination has constrained further development of the Upper Floridan aquifer in the coastal area and created competing demands for the limited supply of water. The Georgia Environmental Protection Division has presented the Georgia Comprehensive Statewide Water Management Plan (Georgia Environmental Protection Division, 2008), which calls for water-resource assessment and management studies and a better understanding of the effects of ground-water pumping in the coastal area.

\section{Objectives}

- Define mechanisms of ground-water flow and movement of saltwater.

- Assess long-term ground-water levels and quality, and develop and maintain a comprehensive ground-water database.

- Update existing ground-water flow and saltwater transport models with new information.

- Simulate a variety of ground-water management scenarios, including:

$\circ$ unchanged or increasing pumpage,

○ pumpage reductions,

- pumpage optimization,

$\circ$ engineered solutions to saltwater intrusion.

\section{Progress and Significant Results, 2006-2007}

- Completed study of saltwater intrusion in the SavannahHilton Head Island area and reported results in Provost and others (2006).

- Completed study of effects of historical and future pumping on regional ground-water flow and saltwater intrusion and reported results in Payne and others (2006).

- Completed study of effects of pumpage reductions on saltwater intrusion and reported results in Payne (2007).

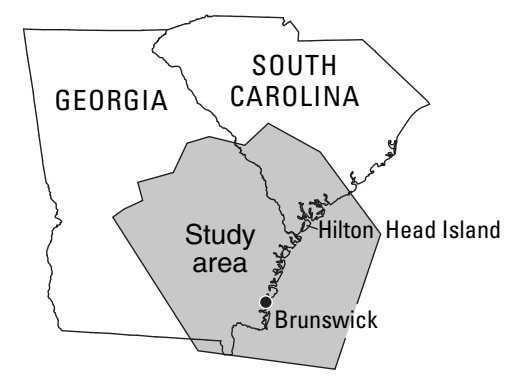

- Developed and installed real-time water-level and specific conductance monitors in wells at Brunswick to track current position of the area of chloride contamination.

- In partnership with City of Brunswick and Glynn County, refined and updated the ground-water flow model to 2004 conditions (Payne and others, 2005) to simulate more precisely conditions near the chloride plume in the Brunswick area.

\section{References}

Georgia Environmental Protection Division, 2008, Georgia Comprehensive Statewide Water Management Plan:

Georgia Water Council, 40 p.; accessed on August 1, 2008, at http://www.georgiawatercouncil.org/Files_PDF/water_ plan_20080109.pdf.

Payne, D.F., 2007, Effects of pumpage reductions in the Savannah, Georgia-Hilton Head Island, South Carolina, area on saltwater intrusion near Hilton Head Island, in Proceedings of the 2007 Georgia Water Resources Conference, March 27-29, 2007: Athens, Georgia, The University of Georgia, 8 p.; available online at http://cms.ce.gatech.edu/ gwri/uploads/proceedings/2007/7.3.2.pdf.

Payne, D.F., Abu Rumman, M., and Clarke, J.S., 2005, Simulation of ground-water flow in coastal Georgia and adjacent parts of South Carolina and Florida-Predevelopment, 1980, and 2000: U.S. Geological Survey Scientific Investigations Report, 2005-5089, 82 p.; Web-only publication available at http://pubs.usgs.gov/sir/2005/5089/.

Payne, D.F., Provost, A.M., Painter, J.A., Abu Rumman, M., and Cherry, G.S., 2006, Application of ground-water flow and solute transport models to simulate selected water-management scenarios in coastal Georgia and adjacent parts of South Carolina and Florida, 2000-2100: U.S. Geological Survey Scientific Investigations Report 2006-5077, 78 p.; Web-only publication available at http://pubs.usgs.gov/sir/2006/5077/.

Provost, A.M., Payne, D.F., and Voss, C.I., 2006, Simulation of saltwater movement in the Upper Floridan aquifer in the Savannah, Georgia-Hilton Head Island, South Carolina, area, predevelopment-2004, and projected movement for 2000 pumping conditions: U.S. Geological Survey Scientific Investigations Report 2006-5058, 124 p.; Web-only publication available at http://pubs.usgs.gov/sir/2006/5058/. 


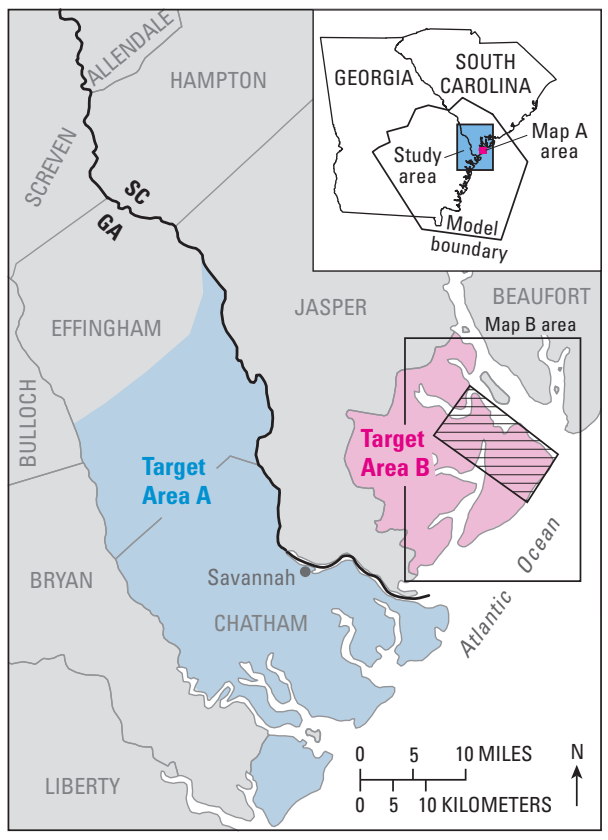

Base from U.S. Geological Survey 1:100,000 and 1:250,000-scale data

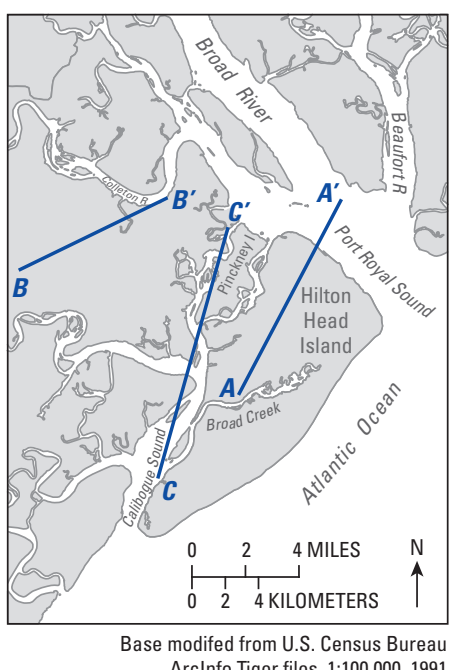

EXPLANATION

Area of inferred chloride plumes

$\boldsymbol{A}-\boldsymbol{A}^{\prime} \quad$ Line of section-See cross sections below

Modeling results. Numerical simulations using a previously published, variabledensity, solute-transport model (Provost and others, 2006) were used to test the relative effects of variable pumpage reductions in Target Areas A and $B$ on the movement of chloride plumes in the Upper Floridan aquifer. Maps show locations of study area and simulated target areas (far left), and section lines (left). Simulation results indicate that saltwater in the Upper Floridan aquifer near the Colleton River (section $B-B^{\prime}$ ) responds more to pumpage reductions in the Savannah area than does saltwater at the northern end of Hilton Head Island (section $\left.A-A^{\prime}\right)$, and that saltwater in the Upper Floridan aquifer at the northern end of Hilton Head Island responds more to local pumpage reductions in the Hilton Head Island area than does saltwater near the Colleton River. Saltwater in the Upper Floridan aquifer at Pinckney Island (section $C-C^{\prime}$ ) responds to pumpage reductions at both Savannah and Hilton Head Island areas.

Between southern Hilton Head Island and northern end of Pinckney Island

Between Savannah and the Colleton River
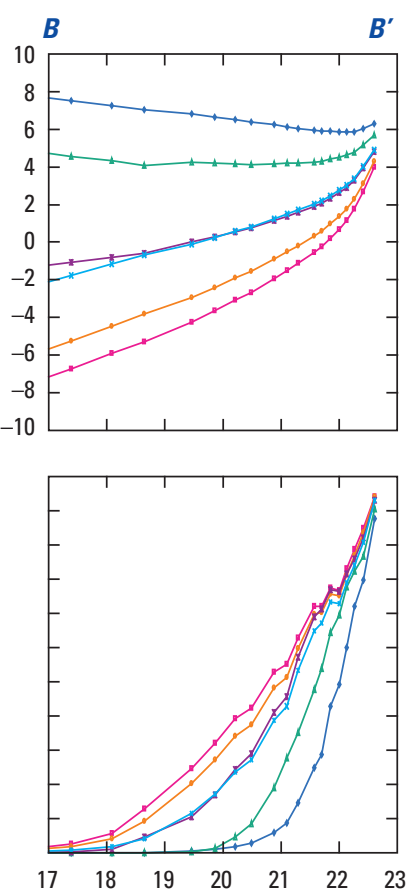

DISTANCE FROM SAVANNAH, IN MILES
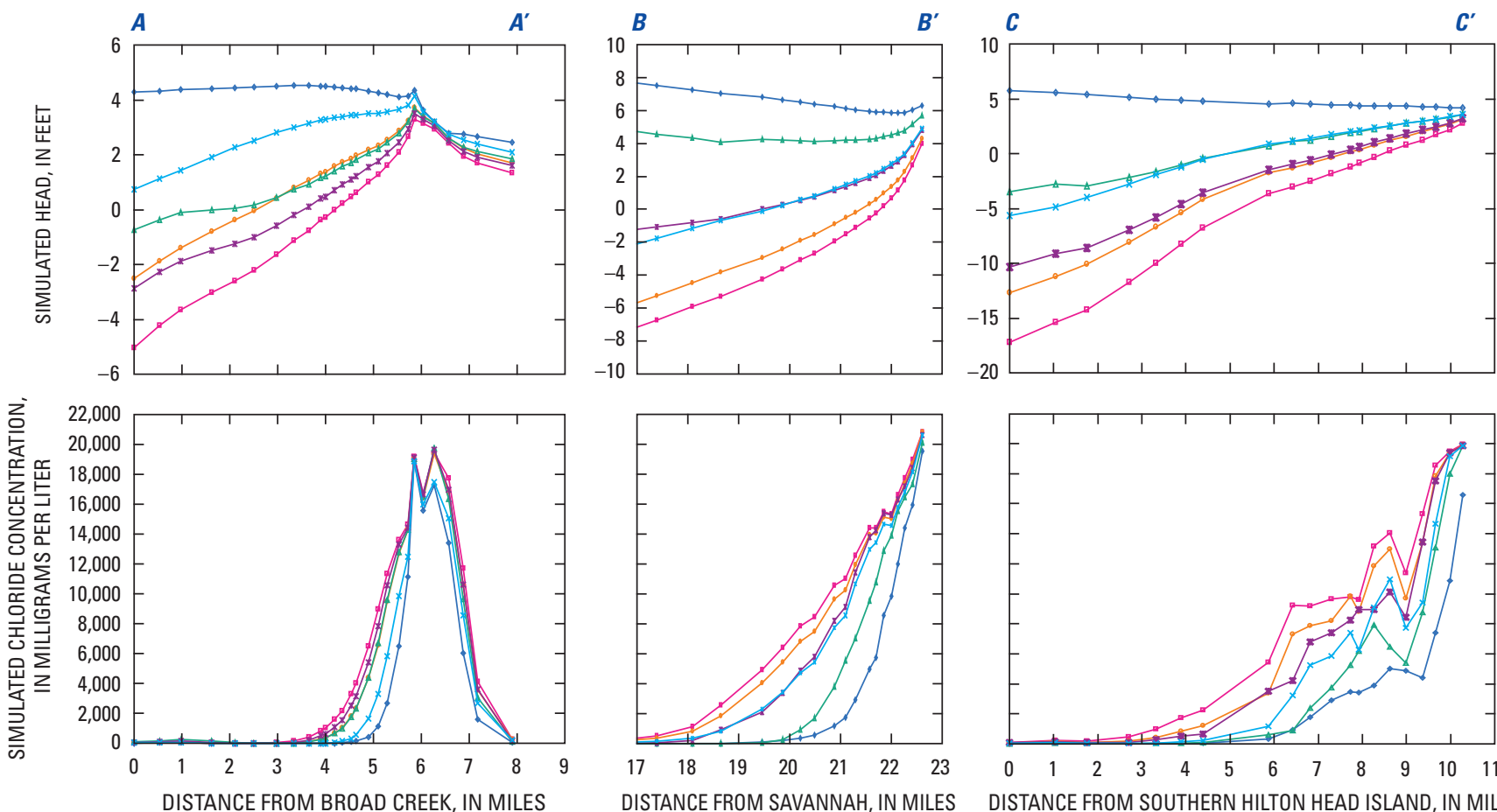

EXPLANATION

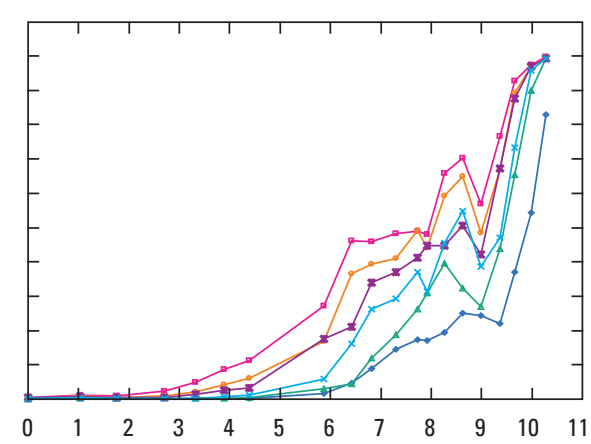

DISTANCE FROM SOUTHERN HILTON HEAD ISLAND, IN MILES

Pumpage reduction scenarios for the Upper Floridan aquifer in the study area

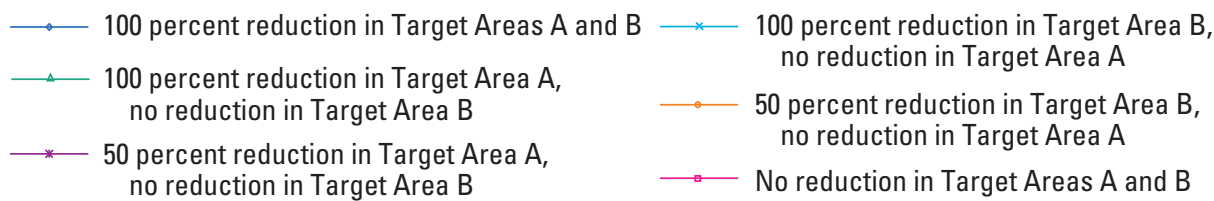




\title{
Hydrogeology and Impact of Pumping on Shallow Water-Bearing Zones and the Upper Floridan Aquifer, South-Central Georgia
}

\author{
Study Chief Lester J. Williams \\ Cooperator Georgia Department of Natural Resources \\ Environmental Protection Division
}

Year Started 2007

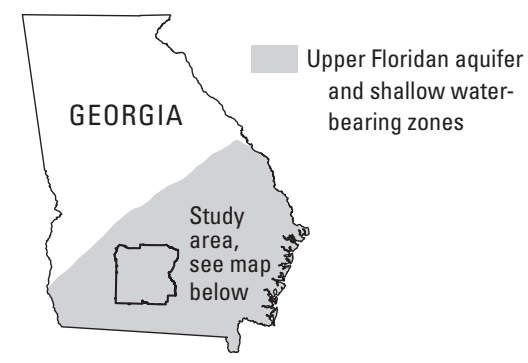

\section{Problem}

During the drought conditions of 2007, ground-water-level declines in south-central Georgia have resulted in numerous domestic wells "going dry," requiring pumps to be lowered or drilling of replacement wells. The cause of the declines is unknown but could be related to reduced recharge during the drought, increased pumping from the Upper Floridan aquifer, or a combination of both. Data from the Statewide groundwater monitoring network indicates that ground-water levels have declined more than 30 feet in the past 30 years (see graph, lower right). Additional data were needed to better define the geologic and hydrogeologic characteristics and the interconnection between the shallow water-bearing zones and the Upper Floridan aquifer.

\section{Objectives}

The objective of this study is to define geologic and hydrologic characteristics and interconnection of the shallow waterbearing zones and the Upper Floridan aquifer. The study area includes eight counties in south-central Georgia (see map, upper right). Field work for this study includes:

- Inventory existing domestic and irrigation wells to provide aquifer data in areas of sparse data coverage.

- Collect core samples and install test wells at selected sites.

- Evaluate paleontology and stratigraphy of core samples.

- Collect borehole geophysical logs in new and existing wells to further define the stratigraphy and hydrogeologic characteristics of the area.

- Conduct aquifer tests in selected wells to determine hydraulic properties and aquifer interconnection.

- Install continuous water-level recorders to establish fluctuations and trends in the shallow water-bearing zones.

\section{Progress and Significant Results, 2006-2007}

- Compiled drilling and well-construction information for domestic and irrigation wells.

- Mobilized and started coring at the $18 \mathrm{~K} 049$ test-drilling site in Tift County.

- Collected borehole geophysical logs from existing wells.

- Prepared field maps and began field well inventories during December 2007.

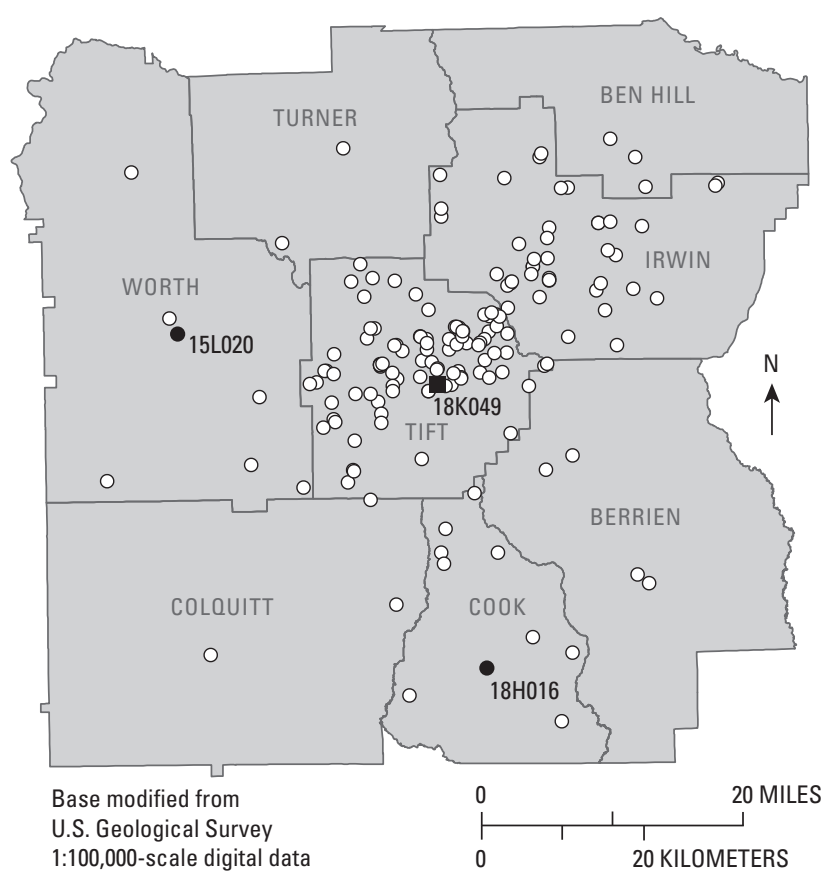

EXPLANATION

○ Water level fell beneath pump setting or bottom of well during 2007 drought

-15L020 Recorder well and number/geophysical log

- 18K049 Test drilling/core site began 2007

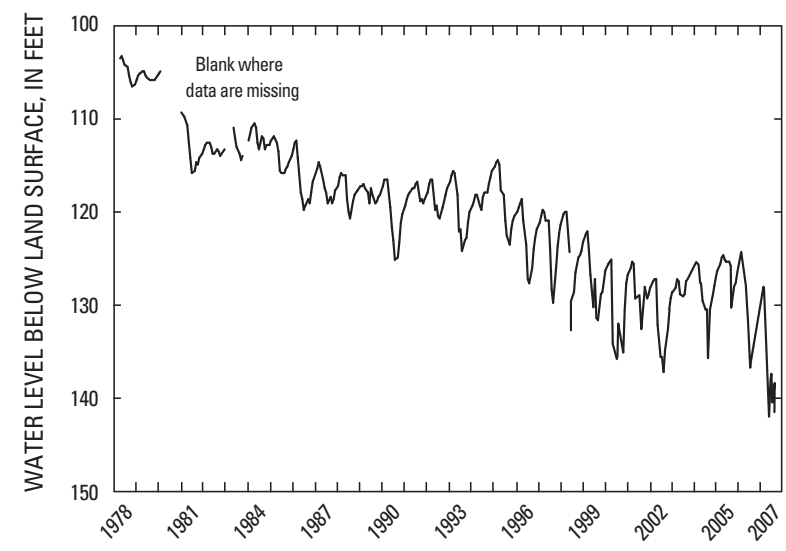

(Top) Location of eight-county study area in southcentral Georgia and (bottom) monthly mean water level for well $18 \mathrm{~K} 049$. 

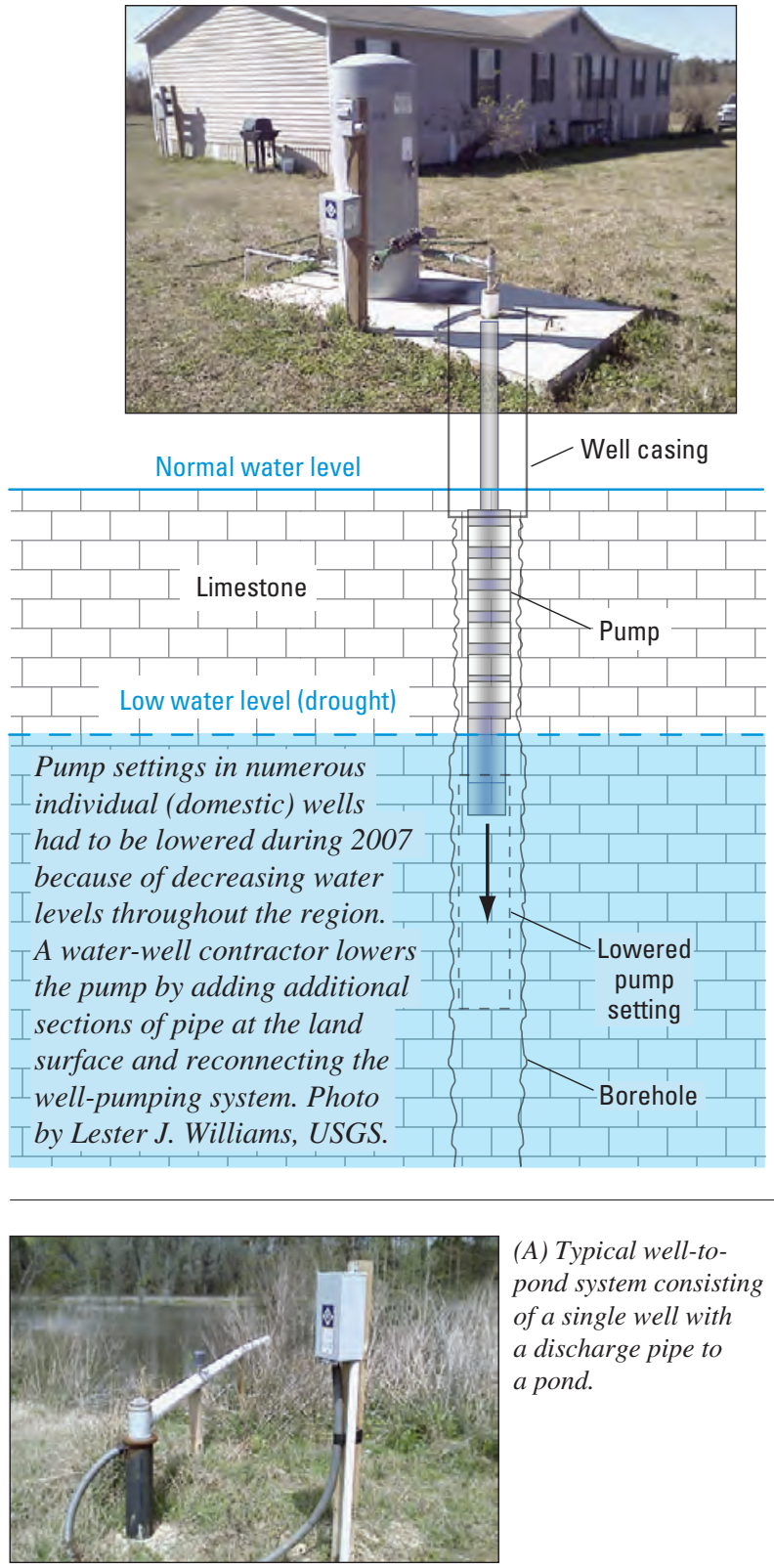

(A) Typical well-topond system consisting of a single well with a discharge pipe to a pond.

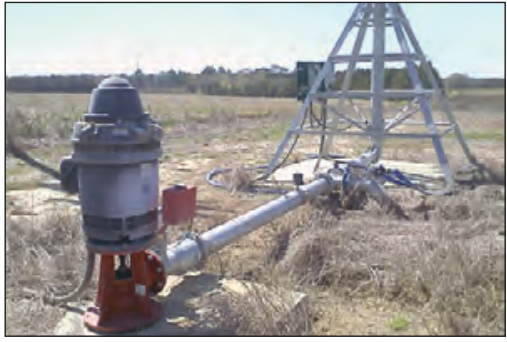

(B) Typical centerpivot system consisting of a well connected to a sprinkler system.

Permitted agricultural wells provide a large source of information on aquifer water levels. Permit holders work with the USGS to provide water levels in many of these wells. Measurements are made during the nongrowing season when the wells are not pumping. (A) Submersible pump installations, such well-to-pond systems, are easy to access; whereas, (B) turbine installations require accessing the well through a port at the base of the well or through the vent pipe. Photos by Lester J. Williams, USGS.

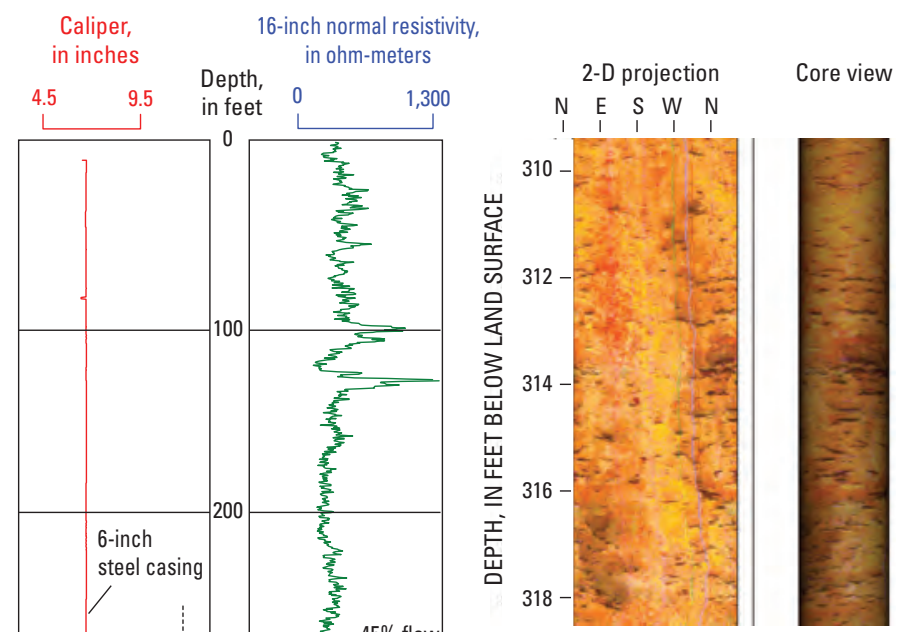

Above: Optical televiewer image from well $18 K 049$ showing a porous section of water-bearing limestone in the open portion of the borehole. Left: Borehole geophysical logs of well $18 \mathrm{~K} 049$ are used to determine the lithologic and hydrologic characteristics of geologic units. The flow-meter log indicates that water is derived from four main zones in this well. [ , approximately; \%, percent; $\mathrm{gal} / \mathrm{min}$, gallon per minute; $A P I U$, American Petroleum Institute Units]

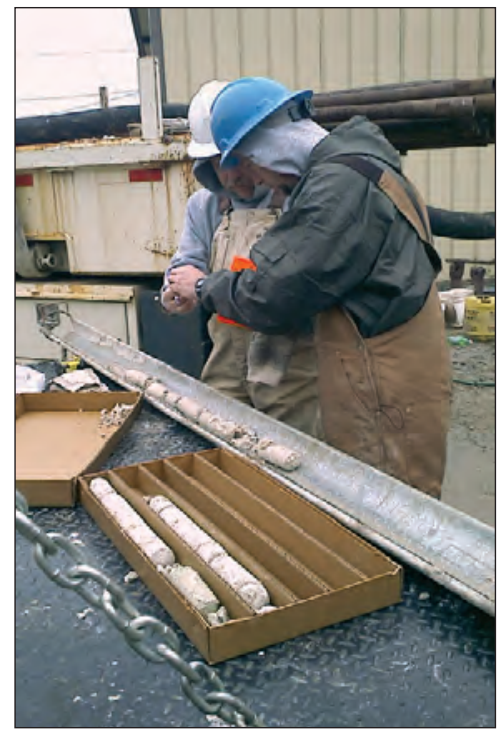

Rock core samples are collected at selected sites to enable assessment of the interconnection between the shallow water-bearing zones and the Upper Floridan aquifer. The photo shows the drilling crew from the Georgia Environmental Protection Division extracting core samples from the Tift County drilling site during November 2007. Photo by Lester J. Williams, USGS. 


\title{
Geohydrology and Effects of Climate and Pumpage Change on Water Resources of the Aucilla-Suwannee-0chlockonee River Basin, South-Central Georgia and Adjacent Areas of Florida
}

\author{
Study Chief Lynn J. Torak \\ Cooperator Georgia Department of Natural Resources \\ Year Started 2006
}

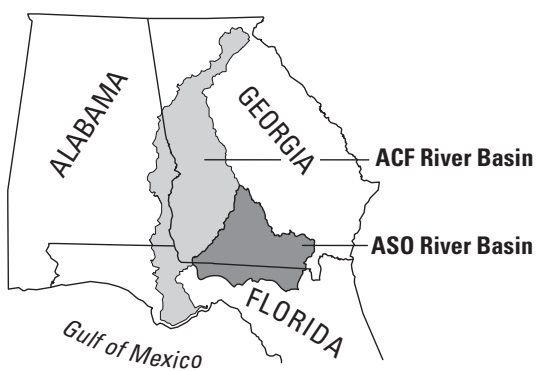

\section{Problem}

Episodic droughts and increased pumpage since the mid1970s have caused unprecedented ground-water level decline in the Upper Floridan aquifer in much of the roughly 8,000 square-mile Aucilla-Suwannee-Ochlockonee (ASO) River Basin. Recent drought has triggered record-low groundwater levels during October 2006 in Charlton, Cook, Tift, Ware, and Worth Counties. A 25-foot water-level decline during the first 10 months of 2006 in Lowndes County nearly negated a post-drought recovery of that amount since 2003. Eastward relocation of municipal pumpage at Cairo, Georgia, during late 1973, reversed 35 feet of ground-water-level decline that occurred during the previous 7 years, giving the appearance of stable-to-increasing ground-water levels.

Increased center-pivot irrigation during the early 1990s along the boundary of the ASO River Basin with the neighboring Apalachicola-Chattahoochee-Flint (ACF) River Basin intercepts ground water previously available to recharge the ASO River Basin as regional (interbasin) flow and accelerates groundwater-level decline in the Upper Floridan aquifer. Drought- and pumpage-induced ground-water-level decline in the Upper Floridan aquifer reduces the hydraulic gradient along the boundary of the ASO and ACF River Basins, which reduces regional groundwater (interbasin) flow to the south and east into the ASO River Basin. Recent pumpage increases threaten the ability of managers to meet current and future demand and increase the potential for reduced spring flow, base flow (ground-water discharge to streams), and interbasin flow from the north and west.

\section{Objectives}

- Improve current understanding of the lithology and hydraulic properties of the Upper Floridan aquifer and hydraulically connected geologic units that enable assessment of ground-water and surface-water exchange.

- Identify spatial and temporal distributions of agriculturalirrigation pumpage from the Upper Floridan that define growing-season variability and cause-and-effect relations of agricultural pumpage to streamflow decline in the basin.

- Develop a hydrogeologic framework and conceptual model for evaluating agricultural pumpage and ground-water and surface-water exchange between the Upper Floridan aquifer and other hydrologic units connected to surface water.

- Collect and compile ground-water-level and streamflow measurements to provide an overview of current hydrologic conditions.

- Develop a conceptual understanding of ground-water and surface-water exchange mechanisms and causal relations between ground-water pumpage in the Upper Floridan aquifer, ground-water-level decline, reductions in streamflow and spring flow, and changes in interbasin flow.

\section{Progress and Significant Results, 2006-2007}

- Measured ground-water levels at about 350 wells, and stream stage and discharge at 83 stations during September 19-29, 2006.

- Mapped potentiometric-surface and stream influence on Upper Floridan and surficial aquifers, September 2006.

- Evaluated and compiled existing hydrologic, geologic, climate, and pumpage information.

- Data collection and compilation thus far indicate

- Complex geologic structure and variations in hydraulic properties create diverse patterns of ground-water flow and recharge in the Upper Floridan aquifer and govern the hydraulic connection and water exchange between the Upper Floridan and surficial aquifers and surface water. Low water-transmitting properties of the Gulf Trough-Apalachicola Embayment limit regional flow and recharge to the aquifer in the Trough-Embayment region.

- Infiltration of precipitation and surface water in the karst region along the Florida-Georgia State line provides recharge to the Upper Floridan aquifer in the ASO River Basin located to the south and east of the Gulf Trough.

- Comparison of historical potentiometric surfaces since the late-1960s indicates changes in ground-water-flow directions across the boundary between ASO and ACF River Basins that coincide with increased agriculturalirrigation pumpage and drought.

- Ground-water hydrographs indicate basinwide response to variations in climate and pumpage despite little hydraulic connection of the Upper Floridan aquifer to land surface and surface water in areas of the Gulf Trough and Okefenokee Swamp.

\section{Reference}

Torak, L.J., and Painter, J.A. 2006, Geohydrology of the lower ApalachicolaChattahoochee-Flint River Basin, southwestern Georgia, northwestern Florida, and southeastern Alabama: U.S. Geological Survey Scientific Investigations Report 2006-5070, 80 p.; Web-only publication available at http://pubs.usgs.gov/sir/2006/5070/. 

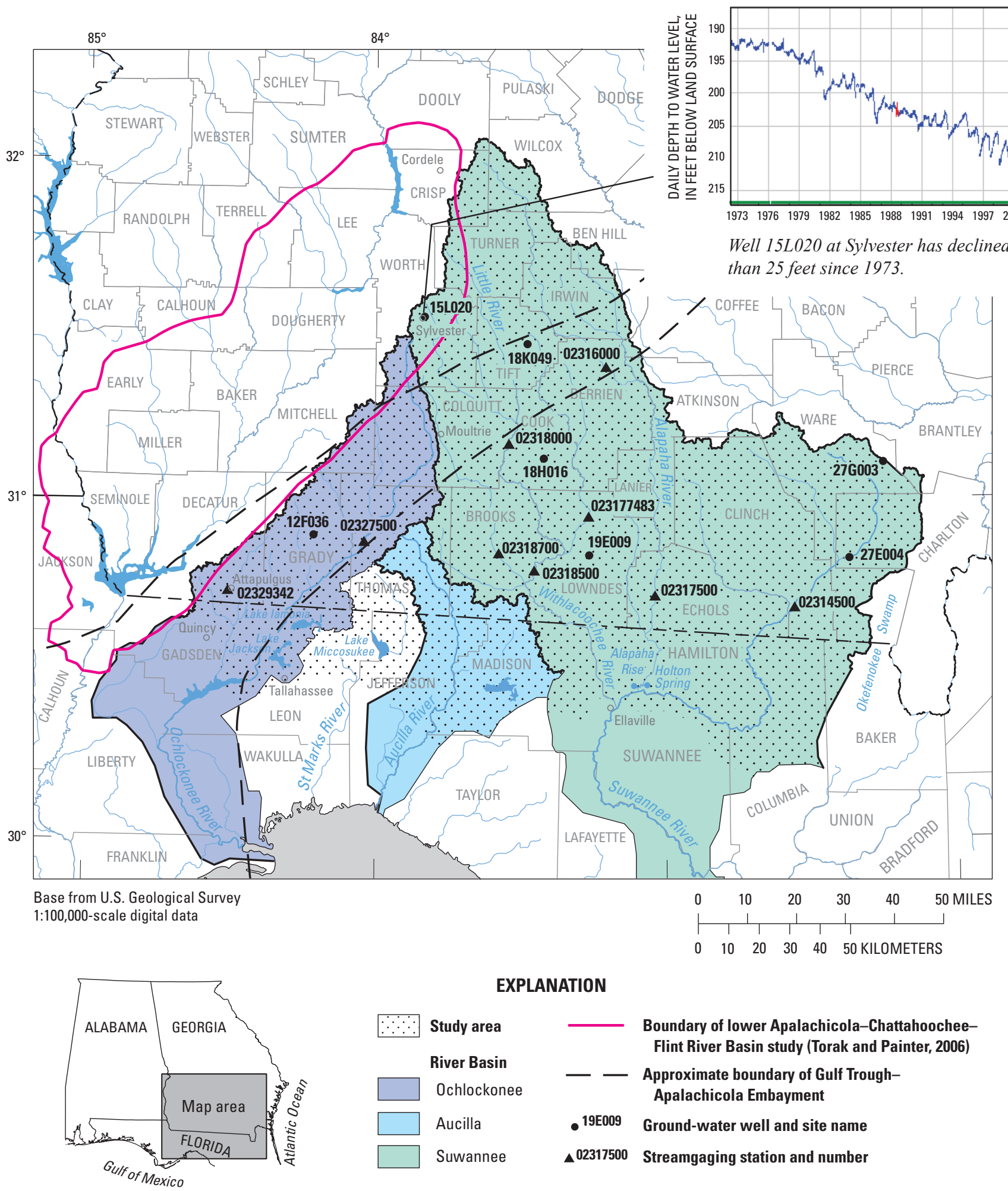

\section{EXPLANATION}

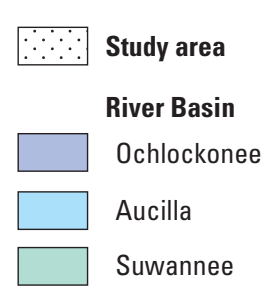

Boundary of lower Apalachicola-ChattahoocheeFlint River Basin study (Torak and Painter, 2006)

- Approximate boundary of Gulf TroughApalachicola Embayment

- 19E009 Ground-water well and site name

$\triangle 02317500$ Streamgaging station and number

Location of study areas in the Aucilla-Suwannee-Ochlockonee River Basin and lower ApalachicolaChattahoochee-Flint River Basin, and continuous-recorder observation wells and streamgaging stations, south-central Georgia and northwestern Florida. Data from these sites are available from the U.S. Geological Survey National Water Information System at http://ga.water.usgs.gov/waterdata.html 


\section{Ground-Water Information and Project Support}

$\begin{array}{ll}\text { Study Chief } & \text { Michael F. Peck } \\ \text { Cooperator } & \text { Georgia Department of Natural Resources } \\ & \text { Environmental Protection Division } \\ & \text { St. Johns River Water Management } \\ & \text { District, Florida }\end{array}$

Year Started 1938

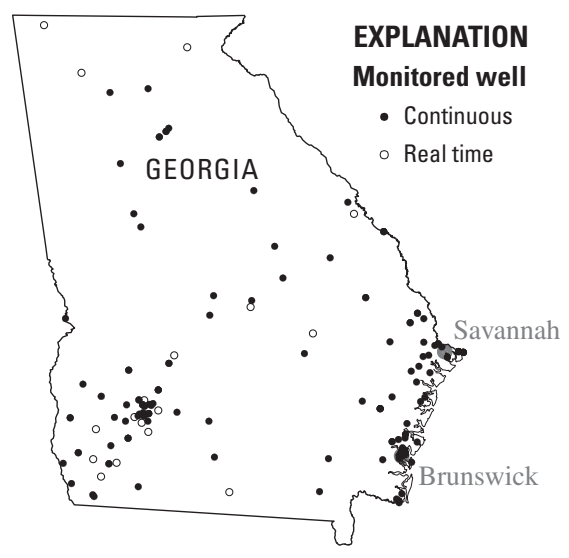

- Periodic water-level measurements were made in more than 3,615 wells to define potentiometric surfaces and to assess long-term trends.

-Water samples for chloride analyses were collected from 72 wells during 2006 and 68 wells during 2007 in the Brunswick area, and from 4 wells in the Savannah area and 8 wells in Camden County.

- Borehole geophysical logs were collected in 13 wells in northern Georgia and in 7 wells in southern Georgia. Data from these wells are available on the Web at http://ga2.er.usgs.gov/geologs/.

- Well-inventory, water-level, and geologic data were verified for entry into the NWIS database. Field inventories of well sites were conducted to assist projects, and 104 sites were added to the NWIS Ground-Water Site Inventory to improve ground-water data coverage in the State. The NWIS database can be accessed on the Web at http://waterdata.usgs.gov/ga/nwis/inventory/.

\section{Reference}

Fanning, J.L., and Trent, V.P., 2009, Water Use in Georgia by County for 2005; and Water-Use Trends, 1980-2005: U.S. Geological Survey Scientific Investigations Report 2009-5002, 186 p.; Web-only publication available at http://pubs.usgs.gov/sir/2009/5002/.

Leeth, D.C., Peck, M.F., and Painter, J.A., 2007, Groundwater conditions and studies in Georgia, 2004-2005: U.S. Geological Survey Scientific Investigations Report 2007-5017, 299 p., CD-ROM; also available at http://pubs.usgs.gov/sir/2007/5017/. 


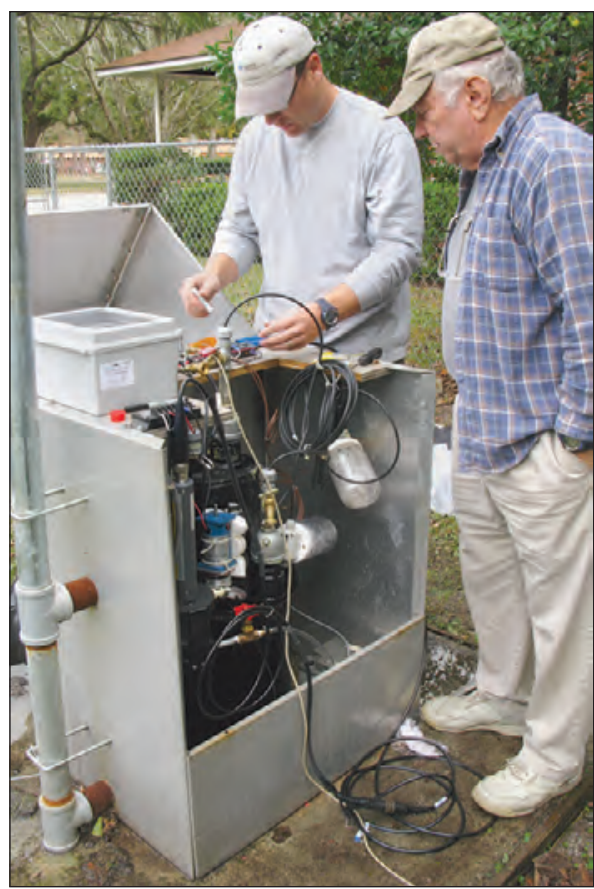

Hydrologic technicians set up a real-time continuous recorder in Glynn County, Georgia, to monitor water-levels and specific conductance. The site is a multipoint well completed in the upper and lower water-bearing zones of the Upper Floridan aquifer. The equipment consists of a data logger, two 30-pounds-per-squareinch transducers to record water levels, an electric pump, and a specific conductance probe. Water levels are measured hourly and specific conductance once-per-day and transmitted by satellite telemetry. Photo by Alan M. Cressler.

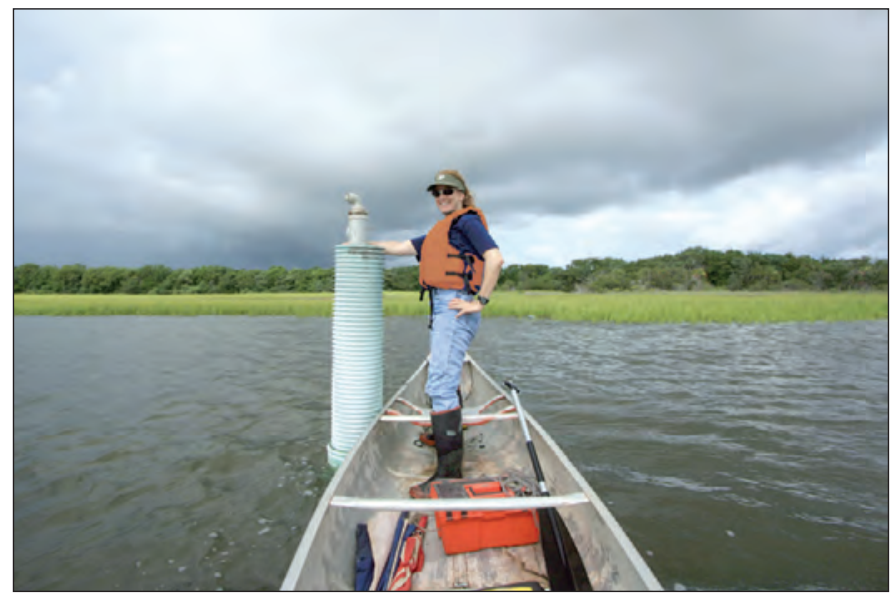

A hydrologist prepares to open a well completed in the Upper Floridan aquifer to collect a water sample. The well, located along the East River in Brunswick, Georgia, can only be accessed during high tide and is allowed to flow for 24 hours before a sample is collected. Samples are collected annually in support of the Brunswick and Glynn County Cooperative Water Resources Program. Photo by Alan M. Cressler.

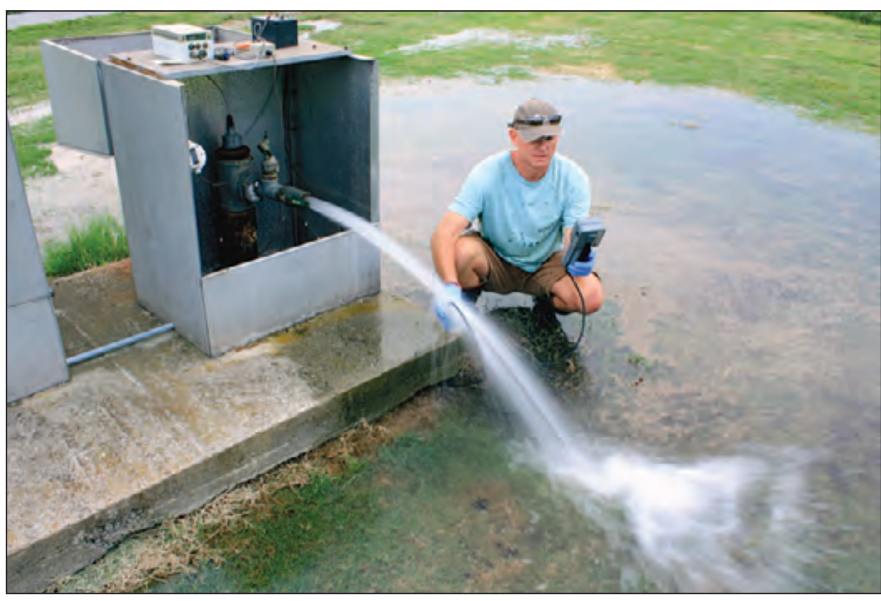

A hydrologic technician from the Ground Water Information and Project Support unit is monitoring the specific conductance prior to collecting a water sample for chloride analysis. The well is completed in the Lower Floridan aquifer and is allowed to free flow for 1 hour before a sample is collected. Samples are collected annually in support of the Brunswick and Glynn County Cooperative Water Resources Program. Photo by Alan M. Cressler.

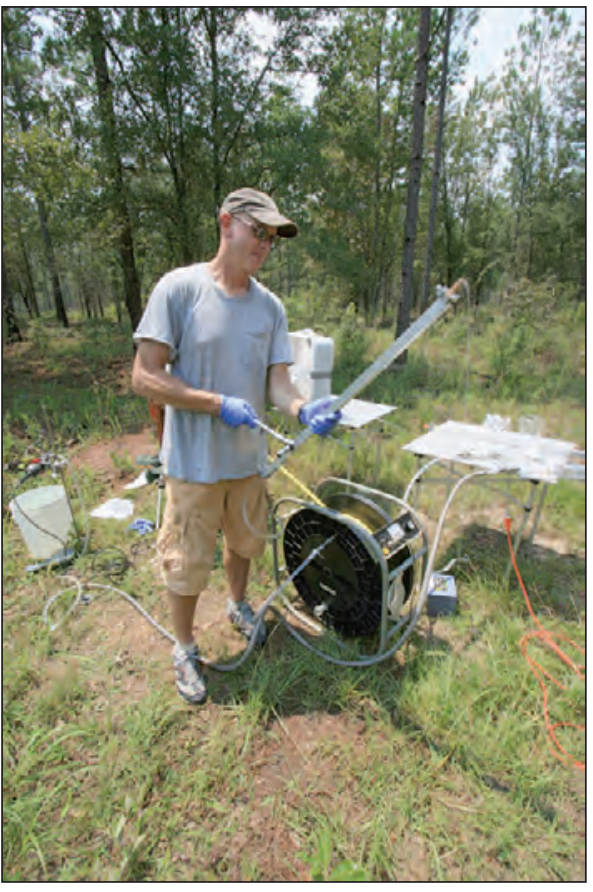

A hydrologic technician from the Ground Water Information and Project Support unit collects a water sample from a well in the Mayhaw Wildlife Management Area, Miller County, Georgia. The well is a reference site that is not affected by agricultural practices, and samples are analyzed for helium for age dating of the water. Photo by Alan M. Cressler. 


\section{Simulation and Particle-Tracking Analysis of Selected Ground-Water Pumping Scenarios at Vogtle Electric Generation Plant, Burke County, Georgia}

\author{
Study Chief \\ Gregory C. Cherry \\ Cooperator \\ U.S. Nuclear Regulatory Commission \\ Year Started \\ 2007
}

\section{Problem}

The Vogtle Electric Generation Plant (VEGP), in Burke County, Georgia, is one of Southern Company's two nucleargenerating facilities in Georgia. On August 15, 2006, Southern Nuclear Company applied to the U.S. Nuclear Regulatory Commission (NRC) for an early site permit (ESP) for an additional two reactors at the site. As part of the ESP permitting process, the NRC is charged with development of an environmental impact statement (EIS) to evaluate the effects of constructing and operating these new reactors on the site and surrounding area. The EIS must describe the magnitude and nature of expected effects on ground water resulting from present and potential future ground-water withdrawal. The assessment should include the area of VEGP and extend for distances great enough to cover potentially affected aquifers, including those within the boundary of the U.S. Department of Energy, Savannah River Site (SRS), located in South Carolina across the Savannah River from VEGP. The addition of two new reactors (Units 3 and 4) at VEGP will require an increase in pumping from the lower Dublin and upper and lower Midville aquifers, which currently provide the water needed for reactor Units 1 and 2. NRC would like to evaluate the effects of additional pumpage on ground-water flow in the surrounding area.

\section{Objectives}

- Simulate the effect of current (2002) and potential future pumping on ground-water levels and flow paths near VEGP for three pumping scenarios in a 4,455-square-mile area near Augusta, Georgia.

- Compare simulated water levels to a Base Case representing 2002 pumping rates throughout the model area.

- Conduct a particle-tracking analysis for each scenario to determine the source of water for VEGP production wells.

- Describe the pumping distribution, simulated water-level changes, and ground-water flow paths relative to the Base Case.

- Define the limitations of the model analysis.

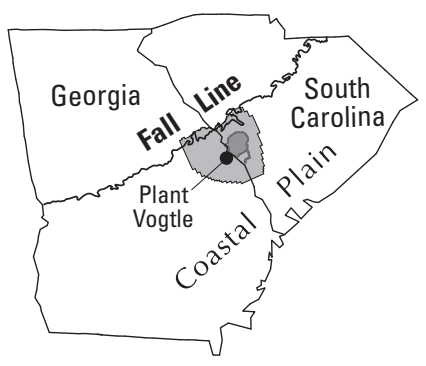

Progress and Significant Results, 2006-2007

- An updated and calibrated MODFLOW ground-water flow model (Cherry, 2006) was used to simulate the effect of current and potential future pumping on ground-water levels and flowpaths near VEGP for a Base Case representing year 2002 conditions and three pumping scenarios (see table). The pumping scenarios focused on pumping increases at VEGP based on projected future demands and the addition of two electrical-generating reactor units. Scenarios simulated pumping increases at VEGP ranging from 1.09 to 3.42 million gallons per day (Mgal/d), with one of the scenarios simulating the elimination of $5.3 \mathrm{Mgal} / \mathrm{d}$ of pumping at the SRS. The largest simulated water-level changes at VEGP were for the scenario whereby pumping at the facility was more than tripled, resulting in drawdown exceeding 4-8 feet (ft) in the aquifers screened in the production wells. For the scenario that eliminated pumping at SRS, water-level rises of as much as 4-8 ft were simulated in the same aquifers at SRS.

- Results of MODFLOW simulations were analyzed using the U.S. Geological Survey particle-tracking code MODPATH to determine the source of water and associated time of travel to VEGP production wells. For each of the scenarios, most of the recharge to VEGP wells originated in an upland area near the Burke and Jefferson County line. None of the recharge originated on the SRS or elsewhere in South Carolina. An exception occurs for the scenario whereby pumping at VEGP was more than tripled. For this scenario, some of the recharge originates in an upland area in eastern Barnwell County, South Carolina. Simulated mean time of travel from recharge areas to VEGP wells for the Base Case and the three other pumping scenarios was between about 2,700 and 3,800 years, with some variation related to changes in head gradients because of pumping changes (see table).

\section{Reference}

Cherry, G.S., 2006, Simulation and particle-tracking analysis of ground-water flow near the Savannah River Site, Georgia and South Carolina, 2002, and for selected water-management scenarios, 2002 and 2020: U.S. Geological Survey Scientific Investigations Report 2006-5195, 156 p.; Web-only publication available at $h t t p: / / p u b s . u s g s . g o v / s i r / 2006 / 5195 /$. 
A

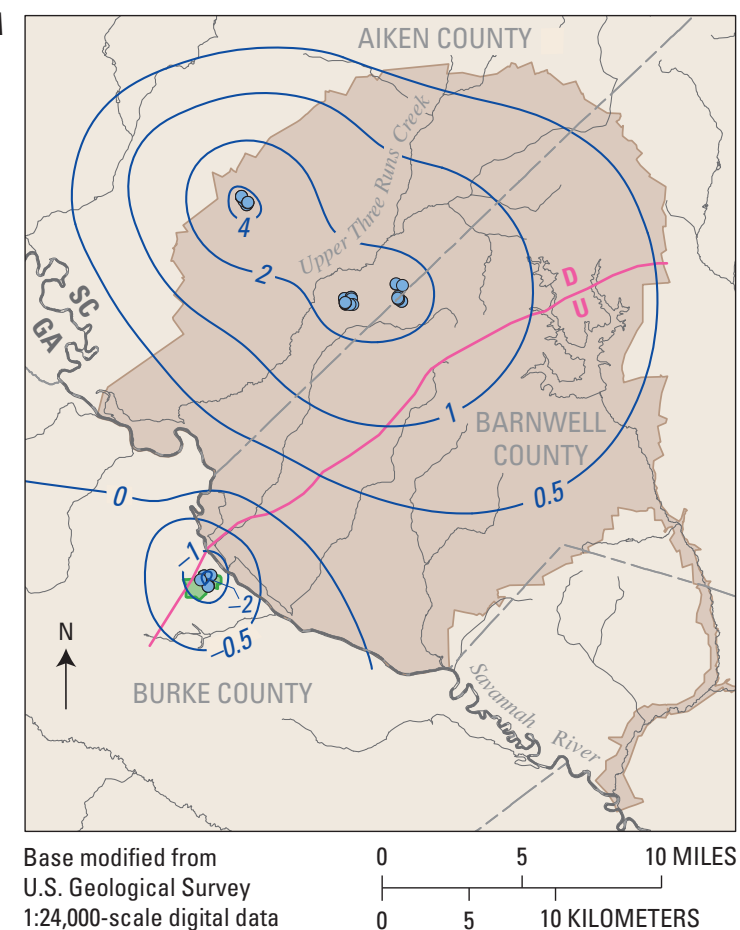

\section{EXPLANATION}

Vogtle Electric Generation Plant

$\frac{D}{\text { U }}$ Pen Branch Fault-Approximately located; D, downthrown side; U, upthrown side

- 1 - Line of equal simulated water-level changeInterval, in feet, is variable. Computed by subtracting the simulated potentiometric surface for 2002 Base Case from the simulated potentiometric surface for Scenario B

- $\quad$ Production well-Completed in the upper Midville aquifer in which pumping was adjusted for scenario

Simulated pumpage at VEGP.

[gal/min, gallons per minute; Mgal/d, million gallons per day]

\begin{tabular}{|c|c|c|c|}
\hline \multirow{2}{*}{ Scenario } & \multicolumn{2}{|c|}{ Pumping rate } & \multirow{2}{*}{ Remarks } \\
\hline & $\mathrm{gal} / \mathrm{min}$ & Mgal/d & \\
\hline $\begin{array}{c}\text { Base Case } \\
2002\end{array}$ & 724 & 1.04 & $\begin{array}{l}\text { Current conditions for existing } \\
\text { reactor units }\end{array}$ \\
\hline A & 1,482 & 2.13 & $\begin{array}{l}\text { Additional pumping capacity of new } \\
\text { reactor units at average projected } \\
\text { withdrawal rates }\end{array}$ \\
\hline B & 1,482 & 2.13 & $\begin{array}{l}\text { Additional pumping capacity of new reactor } \\
\text { units at average projected withdrawal } \\
\text { rates and elimination of } 5.3 \mathrm{Mgal} / \mathrm{d} \\
\text { pumpage at Savannah River Site }\end{array}$ \\
\hline $\mathrm{C}$ & 3,099 & 4.46 & $\begin{array}{l}\text { Scenario represents a higher rate of } \\
\text { withdrawal for the proposed new } \\
\text { reactor units during their startup period } \\
\text { ( } 3.42 \mathrm{Mgal} / \mathrm{d}) \text {, and continuation of year } \\
2002 \text { pumping rates }(1.04 \mathrm{Mgal} / \mathrm{d}) \text { in } \\
\text { the existing reactor units. }\end{array}$ \\
\hline
\end{tabular}

B

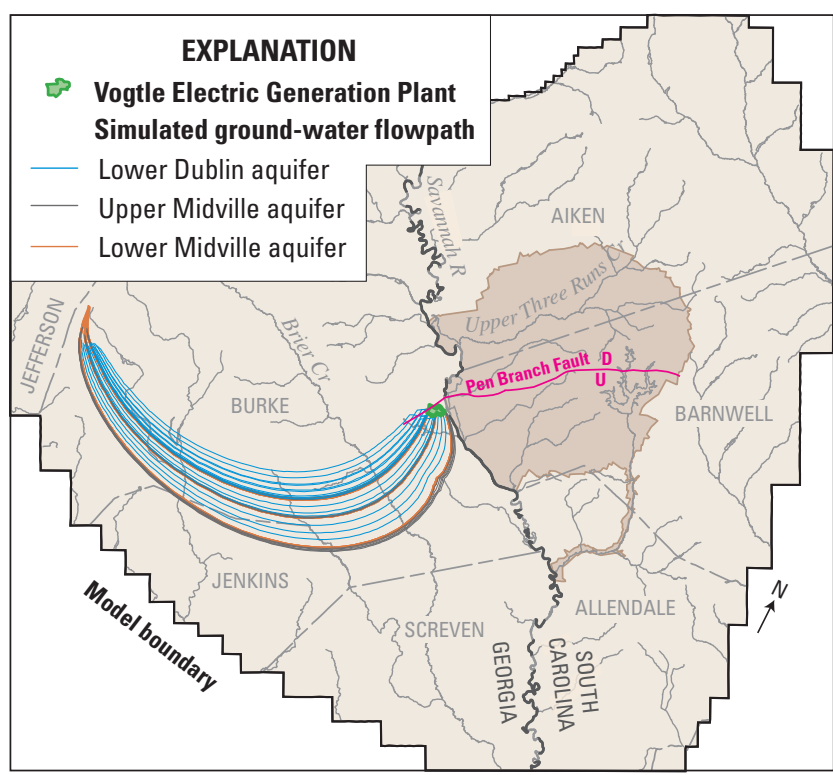

(A) Water-level change in the upper Midville aquifer and (B) particletracking results. For Scenario B, the largest water-level changes were on the SRS, with maximum increases of greater than $4 \mathrm{ft}$ in the Gordon aquifer, greater than $1 \mathrm{ft}$ in the Millers Pond aquifer, greater than $4 \mathrm{ft}$ in the upper Dublin aquifer, greater than $8 \mathrm{ft}$ in the lower Dublin aquifer, and greater than $4 \mathrm{ft}$ in the upper and lower Midville aquifers. The water-level rise resulting from elimination of SRS pumping reduced the effect of pumping at VEGP on ground-water levels. Maximum declines near VEGP were greater than $2 \mathrm{ft}$ in the upper and lower Midville aquifers, greater than $1 \mathrm{ft}$ in the lower Dublin aquifer, and greater than $0.5 \mathrm{ft}$ in the upper Dublin aquifer. There was no observed change at VEGP in the overlying Gordon and Millers Pond aquifers. Simulation results for scenario B indicate that ground-water recharge is provided in an upland area near the Burke and Jefferson County line, with a mean simulated time of travel of about 2,700 years (yr) in the lower Dublin aquifer, about 3,300 yr in the upper Midville aquifer, and about 3,200 yr in the lower Midville aquifer. The fastest simulated time of travel was for a particle in the lower Dublin aquifer (about 2,100 yr), and slowest was for a particle in the upper Midville aquifer (about 5,200 yr). None of the recharge originated on SRS or elsewhere in South Carolina.

Summary of simulated travel time for scenarios in the VEGP model.

[For the simulation, 10 particles were assigned to each aquifer layer in 3 model cells for a total of 30 particles per layer]

\begin{tabular}{|c|c|c|c|c|c|}
\hline \multirow{3}{*}{$\begin{array}{c}\text { Aquifer } \\
\text { (model layer) }\end{array}$} & \multirow{3}{*}{ Statistic } & \multicolumn{4}{|c|}{ Simulated time of travel in years } \\
\hline & & \multirow{2}{*}{$\begin{array}{c}\text { Base Case } \\
2002 \\
\end{array}$} & \multicolumn{3}{|c|}{ Scenario } \\
\hline & & & A & B & C \\
\hline \multirow{4}{*}{$\begin{array}{l}\text { Lower Dublin } \\
\text { (A5) }\end{array}$} & Mean & 2,700 & 2,700 & 2,700 & 3,800 \\
\hline & Median & 2,700 & 2,600 & 2,700 & 3,000 \\
\hline & Maximum & 3,600 & 3,700 & 3,900 & 12,600 \\
\hline & Minimum & 2,100 & 2,100 & 2,100 & 1,800 \\
\hline \multirow{4}{*}{$\begin{array}{l}\text { Upper Midville } \\
\text { (A6) }\end{array}$} & Mean & 3,100 & 3,100 & 3,300 & 2,800 \\
\hline & Median & 2,800 & 2,700 & 2,700 & 2,500 \\
\hline & Maximum & 3,700 & 4,700 & 5,200 & 4,000 \\
\hline & Minimum & 2,700 & 2,300 & 2,300 & 1,800 \\
\hline \multirow{4}{*}{$\begin{array}{l}\text { Lower Midville } \\
\text { (A7) }\end{array}$} & Mean & 3,100 & 3,100 & 3,200 & 2,800 \\
\hline & Median & 2,900 & 2,800 & 2,800 & 2,500 \\
\hline & Maximum & 3,800 & 4,200 & 4,600 & 4,000 \\
\hline & Minimum & 2,700 & 2,400 & 2,400 & 2,400 \\
\hline
\end{tabular}




\section{Monitoring of Ground-Water and Surface-Water Resources in the City of Lawrenceville Area}

\author{
Study Chief Lester J. Williams and Paul D. Ankcorn \\ Cooperator City of Lawrenceville, Georgia \\ Year Started 2002
}

\section{Problem}

Ground water from wells completed in fractured crystalline rock provides about 6 percent $(0.12$ million gallons per day) of the water supply to the city of Lawrenceville, Georgia. Additional ground-water withdrawal is planned in the Redland-Pew Creek and Alcovy River Basins. To enable informed decisions, city managers want to be able to quantify the effects (if any) of ground-water pumping on the surface-water resource as development increases. In addition, city managers recognize a need to collect data to help evaluate the effects of natural and human factors on stream-water quality and, thus, evaluate best-management practices.

To support long-term management goals, the city of Lawrenceville, in cooperation with the U.S. Geological Survey, established a hydrologic monitoring network. The network consists of ground water (regolith and bedrock wells) and surface water (streamgages) sites in the two newly developed basins and in a background basin (upper Apalachee River Basin) that is not influenced by the main pumping centers. An additional streamgage was installed in each of the basins and, beginning in 2006, in the Shoal Creek Basin. The data and information collected during the study can be used by local resource managers to develop a sustainable ground-water supply while minimizing the effects on surface-water resources. The data also will help in understanding changes in surfacewater quality over time.

\section{Objectives}

- Monitor the effect of increased ground-water withdrawal on ground-water levels and streamflow.

- Determine pre- and post-pumping hydrologic budgets of the Redland-Pew Creek Basin.

- Monitor surface-water flow and precipitation at four monitoring sites.

- Monitor surface-water quality at two of the four surface-water-flow monitoring sites.

\section{Progress and Significant Results, 2006-2007}

- Maintained two continuous ground-water-level recorders in the upper Alcovy River Basin, two in the RedlandPew Creek River Basin, and one in the upper Apalachee River Basin.

- Obtained intermittent water-level measurements at 21 monitoring wells.

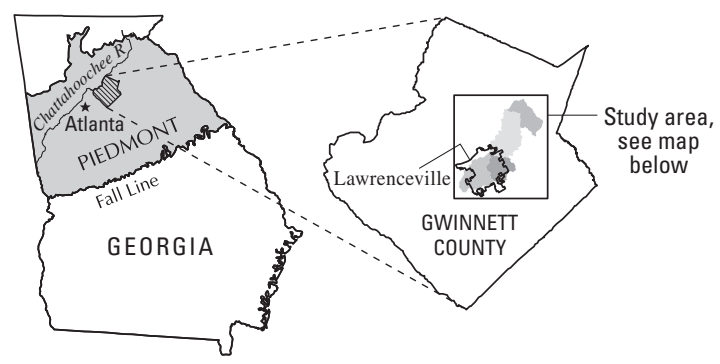

- Installed continuous-recording streamgage and waterquality monitoring station for the Shoal Creek Basin.

- Maintained continuous-recording streamgages at the outflow of the upper Alcovy River Basin, the upper Apalachee River Basin, the Redland-Pew Creek Basin, and the Shoal Creek Basin to establish information on base flow, runoff, and other hydrologic properties, including selected water-quality characteristics.

- Maintained and obtained streamflow readings at four additional staff-gage monitoring sites.

- Made low-flow (seepage) measurements during fall 2006 (22) and 2007 (8) low-flow period to quantify the groundwater contribution to streamflow in areas being monitored.

- Completed packer testing of well 14FF55 to investigate elevated uranium levels in water samples collected from specific intervals within the well.

- Updated the project Web site, which can be accessed at http://ga.water.usgs.gov/projects/lawrencevillegw/.

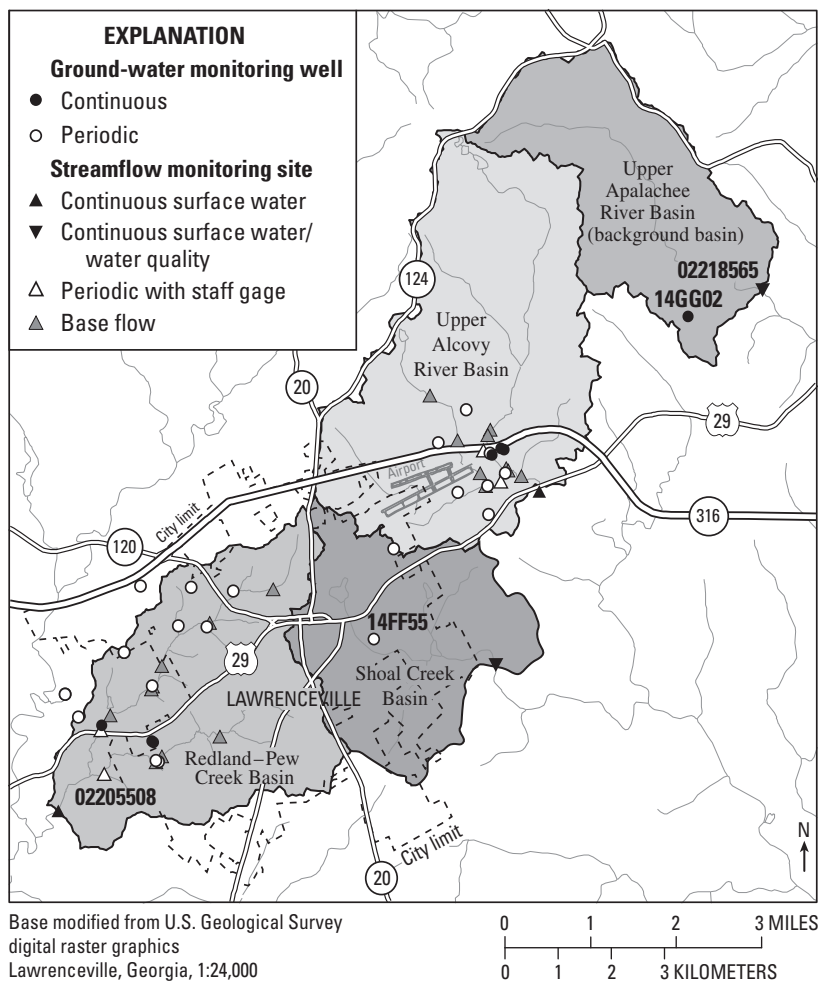

Location of the Lawrenceville study area in the Piedmont physiographic province of Georgia. 

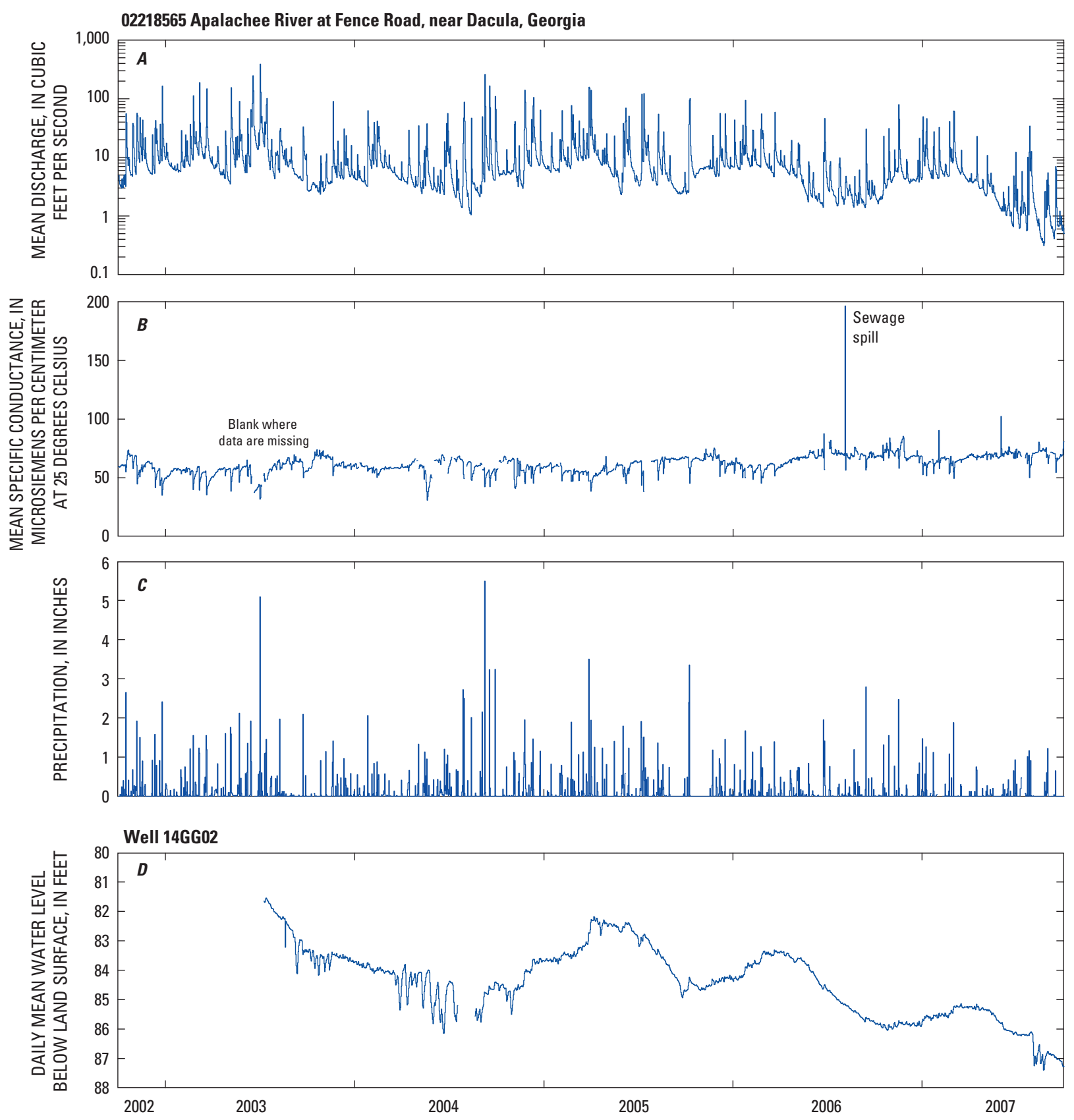

Hydrographs from monitoring sites in the upper Apalachee River Basin for (A) discharge, (B) specific conductance, and $(C)$ precipitation from station 02218565 on the Apalachee River at Fence Road; and (D) water level in well $14 G G 02$ near Dacula, Georgia. Data collected in the upper Apalachee River Basin represent an area that has been minimally affected by development of the ground-water resource (background watershed). Changes in stream water quality can be detected by using specific conductance data (B), which clearly show a sewage spill during late 2006. (Right) A hydrologic technician measures low flow by using an acoustic doppler velocity meter at station 02205508 along Pew Creek near Lawrenceville, Georgia. Photo by Alan M. Cressler, U.S. Geological Survey.

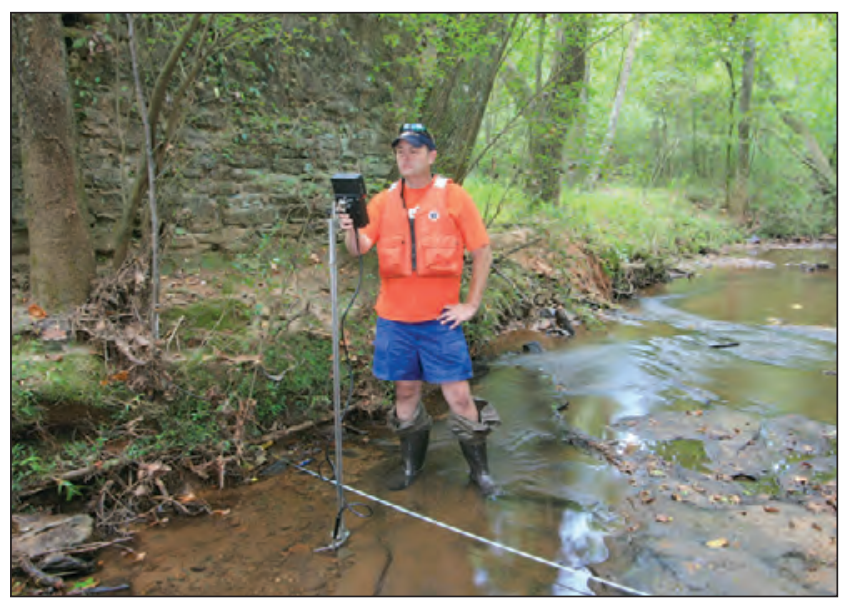




\section{U.S. Geological Survey U.S. Air Force Plant 6 Remediation Assistance Program}

\author{
Study Chief John S. Clarke \\ Cooperator U.S. Air Force, Aeronautical System Center \\ Year Started 1995
}

\section{Problem}

U.S. Air Force Plant 6 (AFP6) in Marietta, Georgia, is a government-owned, contractor-operated, military-aircraft fabrication and repair facility. As part of the operations at AFP6, large quantities of petroleum fuels, oils, lubricants, chlorinated solvents, and protective coatings are used. Past manufacturing practices have resulted in the release of volatile organic compounds (VOCs), primarily trichloroethylene (TCE), tetrachloroethylene, and benzene, along with semivolatile organic compounds and metals into the soil and ground water at the plant. In 1995, dissolved TCE was detected in a groundwater sample collected from a new, unused irrigation well located at Southern Polytechnic and State University, which indicated that VOCs may have migrated offsite of AFP6 (Stewart, 2000). These ground-water contaminants are transported through discontinuities in the otherwise impermeable crystalline rock. Discontinuities can include fractures, joints, faults, contacts between rock bodies, shear zones, and bedding planes.

The U.S. Geological Survey (USGS), in cooperation with the U.S. Air Force (USAF), Aeronautical System Center (ASC), is conducting a multidiscipline, field-based study to improve understanding of contaminant fate and transport in a fractured crystalline-rock setting and to support remedial activities at AFP6.

\section{Objectives}

- Support and enhance environmental remediation activities at AFP6, with emphasis on contaminant hydrology.

- Monitor ground-water level and quality.

- Assist and advise ASC contractors.

- Conduct specific characterization and delineation efforts that directly support remediation.

\section{Progress and Significant Results, 2006-2007}

The USGS continued to investigate contaminant migration in fractured crystalline rock in support of ASC environmental remediation activities. Major focuses included the following:

- Geophysical logging and use of a straddle packer to assess hydraulic properties, head, and water quality of waterbearing intervals in boreholes b4mwi, rw203, and rw208.

- Modification of existing bedrock wells sct1, sct2, b4mwhh, ob208c, b4mwi, and pmw10d to enable isolation of discrete water-bearing zones.

- Operation of water-level monitoring network.

- Collection and analysis of well-water samples for VOCs and degradation byproducts.

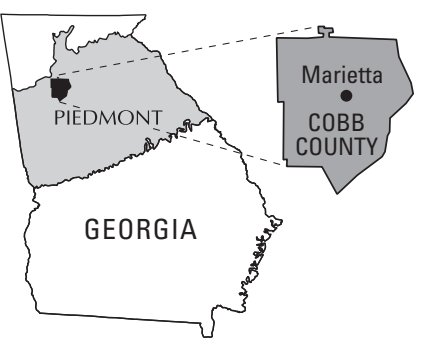

- Assessment of ground-water discharge and contaminant movement to Rottenwood Creek by making streamflow measurements and deploying passive-diffusion samplers during a low-flow period during August 2007.

- Entry of various well data, including geophysical, aquifer test, and water quality, into USGS databases.

- Assessment of offsite migration of contaminants by using tracer studies.

- Development of a AFP6 Web site to serve as a repository for various well data, including geophysical, aquifer test, and water-quality; publications; and other site information. See http://ga.water.usgs.gov/projects/airforce/.

- Publication of a report describing a graphical method to estimate barometric efficiency using continuous waterlevel data (Gonthier, 2007).

\section{References}

Gonthier, G.J., 2007, A graphical method for estimation of barometric efficiency from continuous data-Concepts and application to a site in the Piedmont, Air Force Plant 6, Marietta, Georgia: U.S. Geological Survey Scientific Investigations Report 2007-5111, 29 p.; Webonly publication available at $h t t p: / / p u b s . u s g s . g o v /$ sir/2007/5111/.

Stewart, L.M., 2000, Laboratory analytical results for ground-water sampling at Southern Polytechnic State University, Marietta, Georgia, 1997: U.S. Geological Survey Open-File Report 00-277, 28 p.; available online at $h t t p: / / p u b s . u s g s . g o v / o f / 2000 / o f r 00-277 /$.

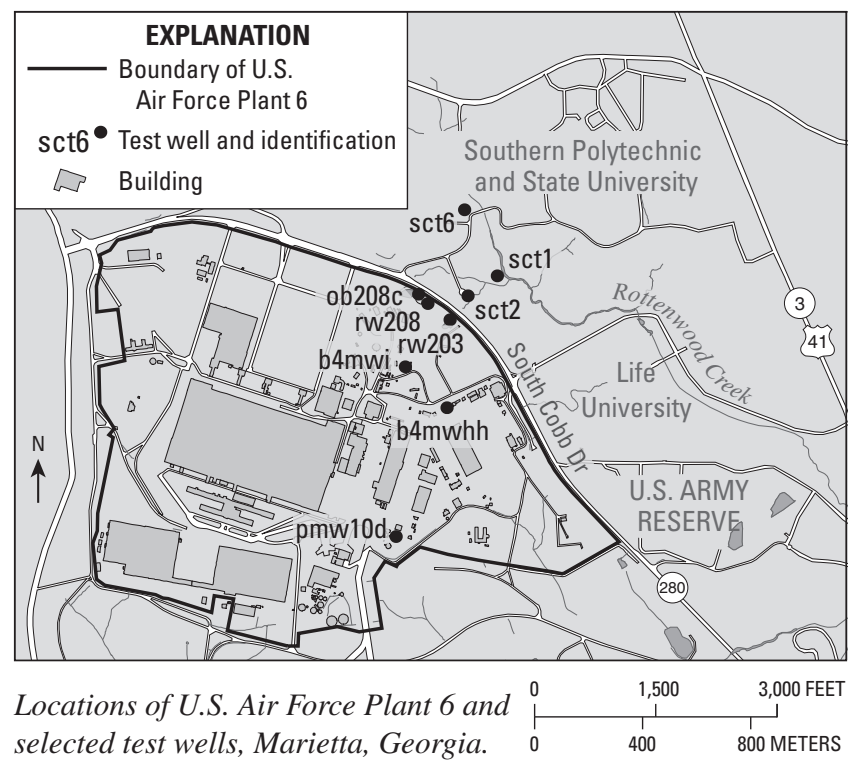




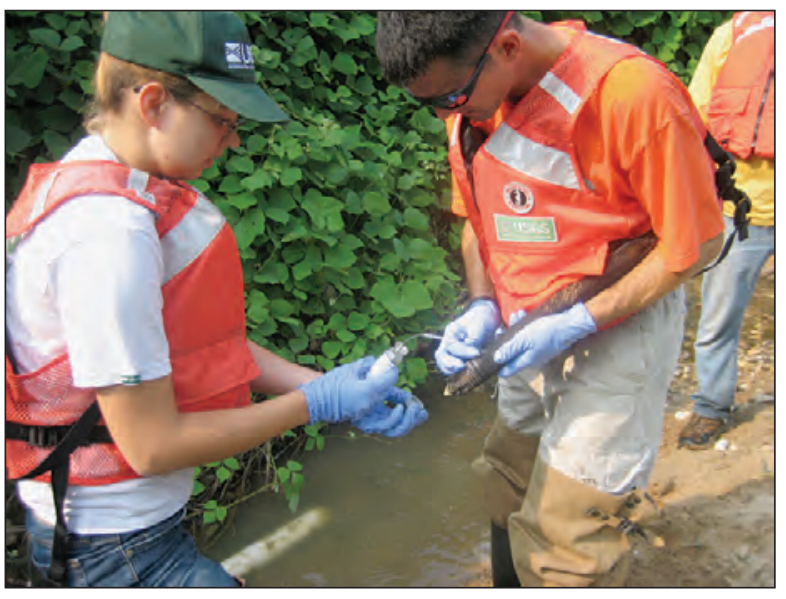

Two USGS scientists collecting a water sample from one of the passive-diffusion samplers deployed in Rottenwood Creek and neighboring tributaries during a low-flow period in August 2007 to measure volatile organic compounds in stream water. Because streamflow during low-flow periods is largely ground-water discharge, concentrations are indicative of ground-water contamination. Photo by L. Elliott Jones, USGS.

sct2-a sct2-b sct-c

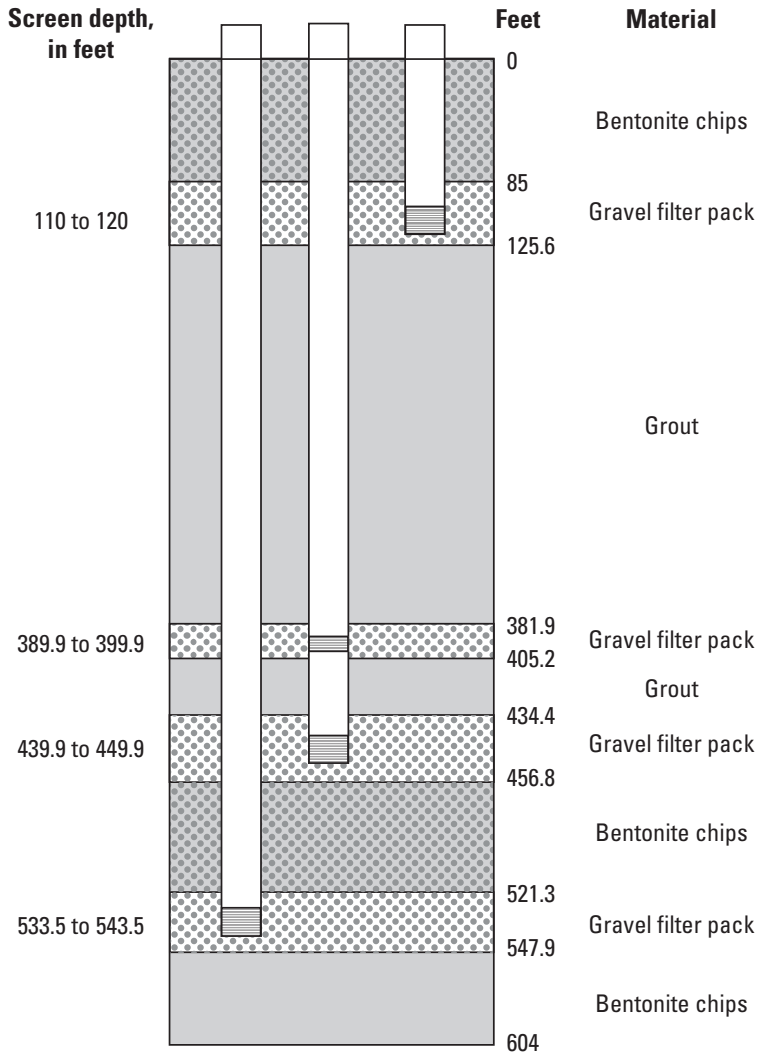

Well sct 2 was modified to isolate discrete water-bearing intervals by constructing three new test wells using bentonite and grout. Well sct2-b includes two screened intervals that are isolated from each other using a continuously inflated packer. Water samples are periodically collected from each of the wells and analyzed for VOCs.

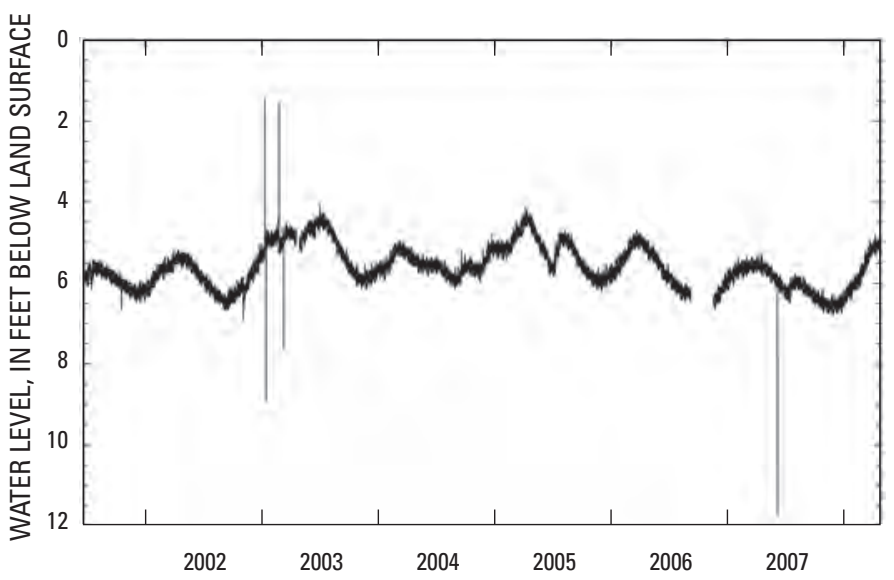

Periodic and continuous water-level data are collected from a network of wells at AFP6. This hydrograph shows continuous water levels in well sct6, a 575-foot deep well completed in bedrock. The hydrograph shows a daily fluctuation that corresponds to earth-tide effects, and a longer-term fluctuation that reflects climatic trends. The sharp spikes on the graph are slug tests or water-sampling events. Data for this well and other wells in the AFP6 network can be accessed at http://ground waterwatch.usgs.gov/countymaps.asp?sc $=13 \& \mathrm{cc}=067$.

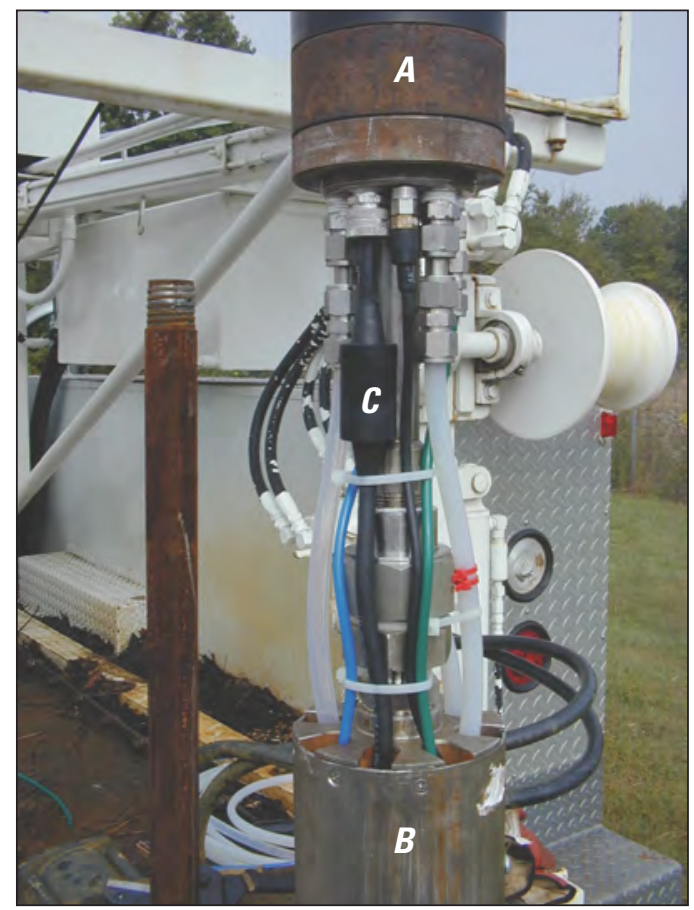

A straddle-packer system used to isolate discrete water-bearing intervals in bedrock wells at AFP6. The system contains the following components: (A) upper packer, $(B)$ lower packer, and $(C)$ tubing and cable connections between middle packer and shroud. Photo by O. Gary Holloway. 


\section{Selected Ground-Water Publications, Conferences, and Outreach, 2006-2007}

Numerous reports, conference proceedings papers, and abstracts were published during 2006 and 2007 that present results of U.S. Geological Survey (USGS) ground-water investigations in Georgia. Oral and poster presentations were given at various technical conferences and outreach events throughout the State. These publications and presentations provide results of investigations conducted in cooperation with State, Federal, and local agencies including the Georgia Department of Natural Resources (mainly the Environmental Protection Division); U.S. Department of Defense, City of Brunswick and Glynn County; Albany Water, Gas, and Light Commission; City of Lawrenceville; and Rockdale County. Most of these publications are Web-only and can be viewed and downloaded at http://ga.water.usgs.gov/publications.html.

\section{Georgia Water Resources Conference for 2007}

The biennial Georgia Water Resources Conference is cosponsored by the USGS and at which results of several USGS investigations are highlighted. The 10th biennial conference was held at The University of Georgia in Athens during March 2007. Twenty-one USGS papers, 11 of which addressed ground-water investigations, were published in the conference proceedings (see bibliographic listing, below).

\section{Other Conferences and Outreach Events}

Other conferences and outreach events in which USGS groundwater scientists participated during 2006-2007 include

- Georgia Association of Water Professionals Spring Conference and Expo, April 2006

- Carl E. Kindsvader Symposium, April 2006

- Geological Society of America, October 2006

- Sunbelt Agricultural Exposition, October 2006 and October 2007

- Georgia Water Resources Conference, March 2007

- Southeastern Coastal States USGS Cooperators' Roundtable, March 2007

- USGS Global Climate Change Workshop, June 2007

- Georgia Public Television, Georgia Weekly, December 2007

- Upper Suwannee River Summit, State of the Basin, sponsored by Upper Suwannee River Partnership and Upper Suwannee River Watershed Initiative, December 2007

- Georgia Ground Water Association, various

- Future Farmers of America

\section{Selected U.S. Geological Survey Reports and Conference Proceedings Articles}

\section{U.S. Geological Survey Reports}

Aulenbach, B.T., 2006, Annual dissolved nitrite plus nitrate and total phosphorus loads for the Susquehanna, St. Lawrence, Mississippi-Atchafalaya, and Columbia River Basins, 1968-2004: U.S. Geological Survey OpenFile Report 2006-1087, 16 p.; Web-only publication available at $h t t p: / / p u b s . u s g s . g o v / o f / 2006 / 1087 /$.

Cherry, G.S., 2006, Simulation and particle-tracking analysis of ground-water flow near the Savannah River Site, Georgia and South Carolina, 2002, and for selected watermanagement scenarios, 2002 and 2020: U.S. Geological Survey Scientific Investigations Report 2006-5195, 156 p.; Web-only publication available at http://pubs.usgs.gov/ sir/2006/5195/.

Cherry, G.S., 2006, Simulation of selected ground-water pumping scenarios at Fort Stewart and Hunter Army Airfield, Georgia: U.S. Geological Survey Open-File Report 2006-1148, 16 p.; Web-only publication available at http://pubs.usgs.gov/of/2006/1148/.

Cherry, G.S., 2007, U.S. Geological Survey Georgia Water Science Center and City of Brunswick-Glynn County Cooperative Water Program-Summary of activities, July 2005 through June 2006: U.S. Geological Survey Open-File Report 2006-1368, 64 p.; Web-only publication available at $h t t p: / / p u b s . u s g s . g o v / o f / 2006 / 1368 /$.

Cherry, G.S., and Clarke, J.S., 2007, Simulation and particletracking analysis of selected ground-water pumping scenarios at Vogtle Electric Generation Plant, Burke County, Georgia: U.S. Geological Survey Open-File Report 2007-1363, 51 p.; Web-only publication available at $h t t p: / / p u b s . u s g s . g o v / o f / 2007 / 1363 /$.

Dalton, M.S., 2006, Cross-sectional data for selected reaches of the Chattahoochee River within the Chattahoochee River National Recreation Area, Georgia, 2004: U.S. Geological Survey Data Series 219, 127 p.; Web-only publication available at $h t t p: / / p u b s . u s g s . g o v / d s / 2006 / 219 /$.

Gonthier, G.J., 2007, A graphical method for estimation of barometric efficiency from continuous data-Concepts and application to a site in the Piedmont, Air Force Plant 6, Marietta, Georgia: U.S. Geological Survey Scientific Investigations Report 2007-5111, 29 p.; Web-only publication available at http://pubs.usgs.gov/sir/2007/5111/.

Gordon, D.W., 2006, U.S. Geological Survey Georgia Water Science Center and Albany Water, Gas, and Light Commission Cooperative Water Program-Summary of activities, July 2005 through June 2006: U.S. Geological Survey Open-File Report 2006-1294, 41 p.; Web-only publication available at http://pubs.usgs.gov/of/2006/1294/. 
Gregory, M.B., Freeman, M.C., and Hughes, W.B., 2006 , Water availability for ecological needs in the upper Flint River Basin, Georgia, 2006: U.S. Geological Survey Fact Sheet 2006-3114, 4 p.; also available at http://pubs.usgs.gov/fs/2006/3114/.

Jones, L.E., and, Torak, L.J., 2006, Simulated effects of seasonal ground-water pumpage for irrigation on hydrologic conditions in the lower Apalachicola-Chattahoochee-Flint River Basin, southwestern Georgia and parts of Alabama and Florida, 1999-2002: U.S. Geological Survey Scientific Investigations Report 2006-5234, 83 p.; Web-only publication available at http://pubs.usgs.gov/sir/2006/5234/.

Landers, M.N., and Painter, J.A., 2007, How much water is in the Apalachicola, Chattahoochee, and Flint Rivers, and how much is used?: U.S. Geological Survey Fact Sheet 2007-3034, 4 p.; also available at http://pubs.usgs.gov/ $f_{s} / 2007 / 3034 /$.

Landers, M.N., and Painter, J.A., 2007, Surface-water conditions in Georgia, water year 2005: U.S. Geological Survey Data Series 252, CD-ROM.

Landers, M.N., Ankcorn, P.D., and McFadden, K.W., 2007, Watershed effects on streamflow quantity and quality in six watersheds of Gwinnett Count, Georgia: U.S. Geological Survey Scientific Investigations Report 2007-5132, 62 p.; also available at http://pubs.usgs.gov/sir/2007/5132/.

Lawrence, S.J., 2006, Description, properties, and degradation of selected volatile organic compounds detected in ground water-A review of selected literature: U. S. Geological Survey Open-File Report 2006-1338, 62 p.; a Web-only publication available at http://pubs.usgs.gov/ofr/2006/1338/.

Leeth, D.C., Peck, M.F., and Painter, J.A., 2007, Groundwater conditions and studies in Georgia, 2004-2005: U.S. Geological Survey Scientific Investigations Report 2007-5017, 299 p., CD-ROM; also available at http://pubs.usgs.gov/sir/2007/5017/.

Musser, J.W., and Dyar, T.R., 2007, Two-dimensional floodinundation model of the Flint River at Albany, Georgia: U.S. Geological Survey Scientific Investigations Report 2007-5107, 49 p.; Web-only publication availble at http://pubs.usgs.gov/sir/2007/5107/.

Payne, D.F., Provost, A.M., Painter, J.A., Abu Rumman, Malek, Cherry, G.S., 2006, Application of ground-water flow and solute-transport models to simulate selected ground-water management scenarios in coastal Georgia and adjacent parts of South Carolina and Florida, 2000-2100: U.S. Geological Survey Scientific Investigations Report 2006-5077, 86 p.; Web-only publication availble at http://pubs.usgs.gov/sir/2006/5077/.
Provost, A.M., Payne, D.F., and Voss, C.I., 2006, Simulation of saltwater movement in the Upper Floridan aquifer in the Savannah, Georgia-Hilton Head Island, South Carolina, area, predevelopment-2004, and projected movement for 2000 pumping conditions: U.S. Geological Survey Scientific Investigations Report 2006-5058, 132 p.; Web-only publication availble at http://pubs.usgs.gov/sir/2006/5058/.

Torak, L.J., and Painter, J.A., 2006, Geohydrology of the lower Apalachicola-Chattahoochee-Flint River Basin, southwestern Georgia, northwestern Florida, and southeastern Alabama: U.S. Geological Survey Scientific Investigations Report 2006-5070, 80 p.; Web-only publication available at http://pubs.usgs.gov/sir/2006/5070/.

U.S. Geological Survey, 2006, Georgia's ground-water resources and monitoring network, 2006: U.S. Geological Survey Fact Sheet 2006-3077, 2 p.; Web-only publication available at http://pubs.usgs.gov/fs/2006/3077/.

U.S. Geological Survey, 2006, Georgia water-use program: U.S. Geological Survey Fact Sheet 2006-3082, 2 p.; Web-only publication available at http://pubs.usgs.gov/ $f_{s} / 2006 / 3082 /$.

U.S. Geological Survey, 2006, Georgia's surface-water resources and streamflow monitoring network, 2006: U.S. Geological Survey Fact Sheet 2006-3084, 2 p.; Web-only publication available at http://pubs.usgs.gov/ $f_{s} / 2006 / 3084 /$.

U.S. Geological Survey, 2006, Georgia's stream-water-quality monitoring network, 2006: U.S. Geological Survey Fact Sheet 2006-3086, 2 p.; Web-only publication available at http://pubs.usgs.gov/fs/2006/3086/.

Williams, L.J., 2007, Hydrogeology and Potentiometric Surface of the Dublin and Midville Aquifer Systems in Richmond County, Georgia, January 2007, U.S. Geological Survey Scientific Investigations Map 2982, 1 sheet; Web-only publication available at http://pubs.usgs.gov/ $\operatorname{sim} / 2007 / 2982 /$.

\section{Georgia Water Resources Conference Proceedings Papers}

[Published in Proceedings of the 2007 Georgia Water Resources Conference, March 27-29, 2007, Todd Rasmussen, Denise G. Carroll, and Aris Georgakakos, eds., The University of Georgia, Athens, Georgia, CD-ROM. All USGS papers also are available on the Web at http://www.gwri.gatech. edu/conferences/previous-gwrc-conferences/gwrc-2007/.

Addison, B., and Williams, L.J., 2007, Community water system collaboration pilot project in Georgia, $2 \mathrm{p}$. 
Carroll, K.P., Rose, S., and Peters, N.E., 2007, Concentration/ discharge hysteresis analysis of storm events at the Panola Mountain Research watershed, Georgia, USA, 5 p.

Cherry, G.S., and Payne, D.F., 2007, Optimization of groundwater pumpage distribution to limit chloride plume expansion in the Upper Floridan aquifer near Brunswick, Georgia, 2 p.

Clarke, J.S., 2007, The monitoring and modeling approach to support ground-water management in Georgia, 7 p.

Fanning, J.L., 2007, Consumptive water use-A critical component of Georgia's comprehensive statewide water management plan, $2 \mathrm{p}$.

Frick, E.A., and Dalton, M.S., 2007, Alachlor and two degradates of alachlor in ground and surface water, southwestern Georgia and adjacent parts of Alabama and Florida, 1993-2005, 6 p.

Gonthier, G.J., 2007, Estimating barometric efficiency using a graphical method on nearly continuous data, $2 \mathrm{p}$.

Gordon, D.W., and Payne, D.F., 2007, Simulation of groundwater flow and nitrate transport in the Upper Floridan aquifer in the southwestern Albany area, Georgia, 4 p.

Gregory, M.B., and Calhoun, D.L., 2007, Response of stream fish assemblages to an urbanization gradient in Metropolitan Atlanta, Georgia, 1 p.

Hall, M.E., and Peck, M.F., 2007, Saltwater contamination in the Upper Floridan aquifer in the Savannah/Vernonburg, Georgia, area, 2004-2006, 3 p.

Horowitz, A.J., Elrick, K.A., and Smith, J.J., 2007, Results from the City of Atlanta water-quality and water quantity monitoring program: suspended sediment, trace element, and nutrient fluxes, 2004-2005, 10 p.
Hughes, W.B., Freeman, M.C., Gregory, M.B., and Peterson, J.T., 2007, Water availability for ecological needs in the Upper Flint River basin, Georgia-A USGS Science Thrust Project, 3 p.

Kath, R., and Williams, L.J., 2007, Development of an Online Database for Storage and Retrieval of Drilling-Log Information for Georgia, $2 \mathrm{p}$.

Knaak, A.E., and Ankcorn, P.D., 2007, Analysis of qualityassurance and quality-control procedures for an urban water-quality monitoring program, Gwinnett County, Georgia, 6 p.

LaFontaine, J.H., McCallum, B.E., Stamey, T.C., and Wipperfurth, C.J., 2007, Flood tracking chart for the Chattahoochee River near Metropolitan Atlanta, Georgia, 2 p.

Leeth, D.C., 2007, Ground-water conditions in Georgia, 2005, $4 \mathrm{p}$.

Musser, J.W., and Leeth, D.C., 2007, Changes in stream temperature for selected streams in Georgia, 1955-2004, 4 p.

Payne, D.F., 2007, Effects of pumpage reductions in the Savannah, Georgia-Hilton Head Island, South Carolina, area on saltwater intrusion near Hilton Head Island, 8 p.

Peters, N.E., 2007, Dissolved constituent concentrations at 21 stream-water monitoring sites in the City of Atlanta from 2003 to 2006,8 p.

Torak, L.J., 2007, Geohydrology and water exchange in the Aucilla-Suwannee-Ochlocknee River basin, south-central Georgia and adjacent areas of Florida: A project overview, $3 \mathrm{p}$.

Williams, L.J., and Cressler, A.M., 2007, Regional effect of pumping ground water from deep fracture systems in the Conyers area, Rockdale County, Georgia, 4 p.
Manuscript approved for publication, March 16, 2009

Edited by Rebecca J. Deckard

Graphics by Caryl J. Wipperfurth and Bonnie J. Turcott

For additional information, please write to:

Director

U.S. Geological Survey

Georgia Water Science Center

Peachtree Business Center

3039 Amwiler Road, Suite 130

Atlanta, GA 30360-2824

http://ga.water.usgs.gov 
